\title{
ACBAR
}

\section{Compilation of the}

\section{VETERINARY}

\section{Sub-committee documentation}

\section{5 \\ to \\ 1997}

Agency Coordinating Body for Afghan Relief

2 Rehman Baba Road

U.P.O Box 1084

University Town

Peshawar,NWFP

Pakistan

TEL: 091 44392/40471

FAX:091-91-840471

EMAIL: acbaar@radio.psh.net.pk

\section{Volume II}

March 1999 


\begin{tabular}{|c|c|c|}
\hline Section: & Contents: & Pages(S) \\
\hline 1997 & $\begin{array}{l}\text { January to December } 1997 \text { Minutes } \\
\text { Strategy for cost recovery on vaccines April } 1997 \\
\text { MADERA Livestock Sector } \\
\text { Animal Husbandry and Veterinary Activities of CoAR during } 1996 \\
\text { PRB Animal Health \& Livestock Production Program }\end{array}$ & $\begin{array}{l}1-55 \\
56-72 \\
73-74 \\
75-78 \\
79-86\end{array}$ \\
\hline 1996 & $\begin{array}{l}\text { January to December } 1996 \text { Minutes } \\
\text { A Review on Veterinary Sub-Committee in } 1996 \\
\text { MADERA Livestock Sector } \\
\text { General update by DCA } \\
\text { ARDA Activity Report } \\
\text { FAO Activities } \\
\text { GAF Activities Report 1-January-November } 1996 \\
\text { ADA Veterinary Services } \\
\text { PRB Activities Report of UFUS } \\
\text { Guidelines for Veterinary Services Association VSA (Draft) } \\
\text { PRB Study on the Nutritional Aspects of Badakhshan Province } \\
\text { Terms of Reference of CCPP Vaccines Produced by MADERA in } \\
\text { Kunar Province. }\end{array}$ & $\begin{array}{l}1-42 \\
43-46 \\
47-53 \\
54 \\
55-57 \\
58-59 \\
60-63 \\
64 \\
65-67 \\
68-82 \\
83-93 \\
94-96\end{array}$ \\
\hline 1995 & $\begin{array}{l}\text { January-December } 1995 \text { Minutes } \\
\text { PRB Activity Report } 1995 \text { for North-East Zone Provinces of } \\
\text { Kunduz, Takhar and Badakhshan } \\
\text { CoAR Veterinary and Animal Husbandry Activity for Afghanistan } \\
\text { Discussion on New CSAs } \\
\text { The Future of NGOs in the VFV System } \\
\text { Livestock mortality in Afghanistan in districts with and without } \\
\text { a veterinary Programme }\end{array}$ & $\begin{array}{l}1-41 \\
42-48 \\
49-50 \\
51-53 \\
54-56 \\
57-72\end{array}$ \\
\hline
\end{tabular}




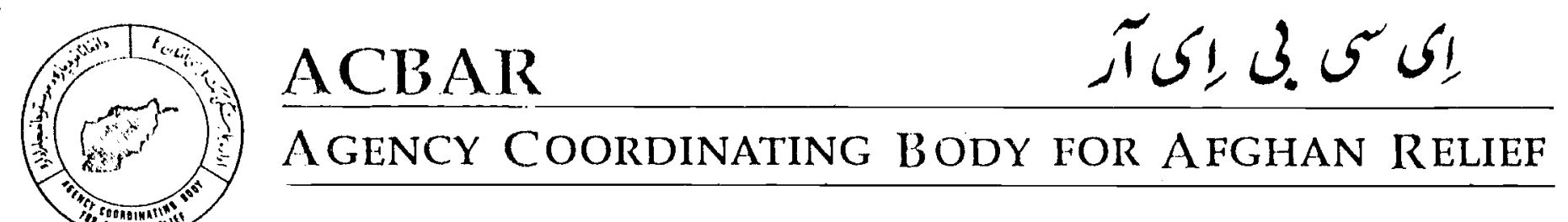

\section{VETERINARY SUE-COMMITTEE MEETING}

\section{January 1997}

The chairman, Dr Salemi, started the meeting with welcoming the participants.

\section{Approval of the agenda}

FAO added "Duplication of VFUs" and "Vaccine Cost Recovery Policy" in the agenda.

"Announcements" was suggested to be an item of the agenda.

\section{Summary of last meeting's minutes, and comments}

No comments were made on the previous minutes.

\section{Announcements}
Romenenpts
FAO announced that cases of Pestes Pest Restromia (PPR) have been reported from Khost and Kandahar in Afghanistan. This disease, affecting sheep and goats, has a high morbidity rate and severely causes, specially abortion in infected animals.

DCA announced that their paravet training course in Kabul is completed. Agencies can nominate trainees for the new course which will probably start at the end of February 1997. It was suggested that well qualified people be recruited for the course. CoAR specifically suggested that BVWs be given paravet training.

\section{TECHNICAL PUBLICATION REVIEW BOARD}

Setting up a technical publication review board was proposed in the last meeting but the issue was put off for this meeting to be discussed fully. After prolonged discussion, the meeting did not agree on setting up the board. It was said that agencies can separately approach the individual members of the sub-committee, taking account of their technical background, for consultation on specific technical issues.

PRB suggested that agencies should send their big and technically significant publications to ACBAR before printing. These publications could be discussed in meetings. Other small publications could be printed by agencies themselves without sub-committee's reviéw. 


\section{FOLLOW UP ON MONITORING MISSION OF CCPP PRODUCTION}

Following the monitoring mission of an assigned working group (in June 1996) to monitor the production of CCPP auto vaccine by MADERA in Kunar, it was decided that MADERA would arrange, as soon as they set up the production procedure, a follow up mission of the same group to monitor the production process. MADERA failed to facilitate the mission in the past year.

MADERA was requested to explain how and when will the mission be arranged. MADERA, in response, reported that their lab in Kunar was very recently closed and will be re-opened in Jalalabad shortly. MADERA, based on recommendation of the monitoring mission, was able to hire an Afghan expert microbiologist, Dr Arzoo, for the lab. The follow up mission will be arranged for in the near future.

\section{Vaccine cost recovery policy}

FAO stated that they have been able to get the EU funding for vaccination in 1997. The funding ensures that vaccine could be served freely for this year. A concern was raised that funding for vaccination in the next years may not be available. Therefore, a policy for vaccine cost recovery is needed. FAO asked the member agencies for views regarding this policy. Under this policy, measures of charging for vaccine cost will be set up. The acquired money will be spared for provision of vaccine in the future, in case donors stop funding.

After some discussion, the participants agree that as the idea has been created it should be supported. It was suggested that, in the next meeting, the initial norms for the cost recovery policy be discussed.

\section{Activity update}

\section{a) By FAO}

FAO, for refresher training, has set up a training section, apart from their administration as a separate NGO. FAO also plans to give priority to veterinarians, paravets and other veterinary workers for poultry training. This will encourage veterinarians to run poùltry forms with professional measures.

b) By NGOs

Activity reports of GAF and CoAR, whose reports were not available in December for circulation, are attached.

\section{Plans for the future}

Due to time constraints, this item was put off for the next meeting. 


\section{Election of chairperson and deputy chairperson}

ACBAR thanked Dr Salemi and Dr Tahir for the successful carry out of the chairperson and deputy chairperson positions of the ACBAR Veterinary Sub-committee during the last year. As per policy, election for these positions take place in the beginning of every vear.

PRB suggested Dr Salemi and Dr Tahir to be elected for another term for their current positions. Reasons were given that both Drs have been efficient and have had a majot role not only in leading the regular meetings but also in transformation of the ordinary and formality oriented meetings into very technical and more practical oriented meetings.

As no other nominations existed, the above suggestion was agreed upon and Dr Salemi and Dr Tahir were elected again for their positions.

ACBAR would like to congratulate both Dr Salemi and Dr Tahir. Meanwhile, it is hoped collaborating with them and other members of the Veterinary Sub-committee will continue to contribute to the veterinary sector and, thus, to achieve a share in assisting the vulnerable nation of Afghanistan.

\section{Any other business}

\section{Rabies vaccination}

GAF expressed concern over the post vaccination situation in the provinces where Rabies vaccination was campaigned. It was reported that the provincial authorities have not been fulfilling their commitments of eliminating the stray dogs. Unless the stray dogs are eliminated, the Rabies could not be controlled. PRB stressed on the need to eliminate the stray dogs. It was reported that stray dogs are the main causes not only for Rabies but also for Cyst Hidatique and Leishmania.

It was requested that ACBAR, in any possible ways, arrange to contact the provincial authorities and, besides reminding them of their commitment, convince them to start killing stray dogs.

\section{Duplication of VFUs}

There has been a general policy within the veterinary sub-committee members that one VFU be supported in a district. FAO stated that they still support this policy. It was strongly stressed that agencies avoid duplication of activities.

\section{CoAR's cow farm}

CoAR said that they plan to establish a cow raising and research farm in Logar province. CoAR asked the participants for solid and detailed suggestions regarding the farm establishment. This discussion was suggested to be postponed for the next meeting.

\section{ARIC library's request}

ACBAR/ARIC is supporting ARIC Box Library Extension (ABLE) programme under which mobile box libraries are run in districts. These libraries have already been running in 
some provinces. ARIC stated that there have been requirements for more books in the running libraries. ARIC requested FAO, in particular, and other agencies who have publications, in general, to provide ARIC with more and enough copies of their publications. ARIC invited the participants to visit the ABLE book collections after the meeting.

FAO said that, for now, they do not have more copies of the books they have submitted to the library. Nevertheless, for the future it will be ensured that enough copies are provided.

After leaving the meeting room, the participants visited Nancy Dupree's office to see the samples of the box library and the books allocated for the libraries. Nancy Dupree kindly briefed the participants on the ABLE services.

THE NEXT MEETING:

THE NEXT VETERINARY SUB-COMMITTEE MEETING IS SCHEDULED TO BE HELD ON 27 FEBRUARY 1997 AT 9:00 AM IN ACBAR CONFERENCE ROOM.

Chairman : Dr M Arif Salemi, TCP/FAO

Minutes : A Jawed Ludin, ACBAR

The participants:

$\begin{array}{ll}- & \text { Dr M A Salemi } \\ - & \text { Dr Mehraban } \\ - & \text { Dr A Ghafoor } \\ - & \text { M Haroon } \\ - & \text { Dr Samsoor } \\ - & \text { Mir Bashir } \\ - & \text { Dr Zimeray } \\ - & \text { Dr Ghulam Saeed } \\ - & \text { Shah M Safi } \\ - & \text { Hamidullah Natiq } \\ - & \text { Dr M S Tahir } \\ - & \text { M Rafi } \\ -\quad & \text { Jawed Ludin }\end{array}$

Coordinator

National Manager

Director

Coordinator

Extension Coordinator

?

Advisor

Veterinary In-charge

Veterinary Coordinator

Community Development Manager Afghanaid

Livestock Coordinator

Field Supervisor

Information Officer
TCP/FAO

FAO

GAF

UVSA

DCA

PRB

PRB

CoAR

ARDA

MADERA

ARIC/ACBAR

ACBAR

Apologies:

Eng Esmatullah, ADA

Absent:

AFRANE, EU, MDC, OXFAM, RAFA and UNOPS. 


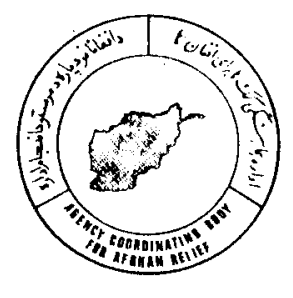

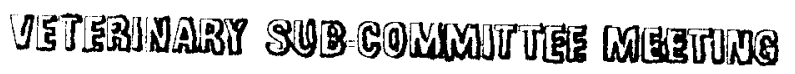 \\ 27 February 1997}

1. Approval of the agenda

Approved.

\section{Summary of last meeting's minutes}

ACBAR briefed the meeting on highlights of the last meeting. The floor was then asked for approval of the minutes.

.. EU has objected on the sentence "FAO stated that they have been able to get the EU funding for vaccination in 1997.", under item 6 (Vaccine cost recovery policy) in the last minutes. In a letter to FAO (cc: ACBAR), EU has suggested correction of
the statement.

ACBAR protested that Mr Barker, in replying letter to EU regarding the above issue, has attributed the error directly to the ACBAR Rapporteur, which is not correct.

FAO apologized and added that there might have been a mistake in reporting as the vaccination funding process is very much inter-linked between FAO and DCA. FAO explained that EU has provided funding for vaccine to DCA. DCA will procure and import vaccine, while the vaccine will be distributed through FAO's programmes to
VFUs.

FAO suggested the above sentence to read "FAO stated that EU has paid DCA for purchase of vaccines in 1997. DCA will purchase vaccine which will be handed over to FAO for distribution to VFUs.

... The term "Pest des Petits Ruminants" has been mis-spelled in the first page, under Announcements (1st line) which should be corrected.

\section{Announcements}

FAO announced that UNDP, for 1997-98, is planning to implement a district development programme in 23 districts of Afghanistan in the provinces of Kandahar, Farah, Samangan, Balkh, Takhar, Badakhshan and Wardak. This programme is termed as Poverty Eradication \& Community Empowerment (PEACE). FAO, being a UNDP supported programme, will assist in implementation of the Afghanistan PEACE initiative through its veterinary clinics (FAO currently supports clinics in 244 districts of Afghanistan while this number, in 1997-98, will be increased to 255). The PEACE programme, in 23, UNDP focus districts, will include integrated livestock activities 
including women programme in addition to the VFU network.

Based on MADERA's claim that they already have activities in different sectors in Behsud district of Wardak, which is included in UNDP's district development programme, FAO said that they will consult UNDP whether to include Behsud in the PEACE initiative, as there are already similar programmes implemented, and instead look for some other districts. FAO added that UNDP should consult ACBAR and ask for list of agencies and their activities in these 23 districts.

\section{Initial norms for vaccine cost recovery policy}

Although it was agreed in the last meeting that a policy for vaccine cost recovery be worked out, many of the participants in this meeting maintained negative stand against this policy. The representatives of MADERA, CoAR and ARDA gave different reasons for opposing this policy. CoAR stated that Afghan farmers are too poor to be over charged for such services and that this will badly discourage the interest for vaccination. MADERA said that vaccination is not a local issue. It rather concerns the international community and the donors will always keep interest in funding it. ARDA was concerned that charging for vaccine cost will be too much for the farmers who already pay for the vaccination fee.

On the other hand, some other agencies, including FAO, ADA, GAF and PRB, supported the idea of vaccine cost recovery policy. They believed that the donor support cannot be trusted for long. It may stop anytime. In order to ensure that Afghanistan livestock will continue to have vaccination even if the donor community stops paying for it, setting up such a policy is very necessary. Afghanistan will need to stand on its own feet, if not today, tomorrow; why shouldn't we start now. Widening the dependency in Afghanistan is a much bigger problem than, for example, lack of vaccination. For the Afghan farmers, who currently pay for medicine, vaccination fee, agriculture inputs and so many other things, paying for vaccine will be a small addition, while, for Afghanistan, it will be a great achievement to afford vaccination without foreign help.

It was, however, clarified that vaccine cost recovery policy will not be so simply implemented for all Afghanistan at one time. At the first step, only some vaccines, which can be charged for, will be charged for in only some areas, where it is possible and farmers are willing to pay.

FAO stated that similar objections were made five years ago when charging for veterinary vaccine was suggested. Now Afghan farmers pay millions of US dollars for animal medicine. We believe they can pay for vaccine as well. We do not want a $100 \%$ cost recovery for all vaccines being used across the country. But we have to agree on a starting point.

It was stated that FAO has decided to enforce vaccine cost recovery. But there are still many questions about when, where, how and which vaccine, ..., which need to be discussed. FAO stressed that the next meeting should finalize setting up the initial norms for this policy. It was suggested that, if possible, authorized representatives of the organizations involved in veterinary activities be invited to the next meeting to add 
to the authority of decision making in the meeting. FAO requested the NGOs to consult with their field staff and get their opinions regarding adoption of the policy and the details on which vaccine, where, what cost (percentage), when to start, when can $100 \%$ cost recovery be achieved, etc.

\section{Activity update}

Postponed for the next meeting due to limited time.

\section{Any other business}

\section{DUPLICATION OF VFUs}

Since a long time, there have been complains about duplication of veterinary activities in some districts. CoAR has allegedly been responsible for the duplication. While CoAR has repeatedly refuted this. According to ACBAR veterinary policy, normally only one VFU should be run in one district. In case population, territory, etc of a district requires more clinics, more clinics could be supported but their activities should be very coordinated and under the same management. Some agencies also blame CoAR that they sell medicine at subsidy rate which causes troubles for the FAO supported clinics who sell medicine with no subsidy. CoAR, in response, says that they sell medicine with no subsidy, and that the problem is with the veterinarians in FAO supported clinics who are free to sell at any higher price as possible. There should be at least a limit for medicine price.

ACBAR strongly stressed that this issue should be resolved as it has been continuing for a long time now. ACBAR listed the specific problems mentioned as:

Duplication of VFUs in Baraki district, Logar, between CoAR and GAF; duplication of VFUs in Sayedabad district, Wardak, between CoAR and ADA; duplication of VFUs in Jaghatu district, Ghazni, between CoAR and GAF; and difference in medicine prices and other charges.

It was decided that this issue be resolved in the next meeting. For a fair decision, some points, ie history of presence in a district, other options in case decided to abandon, etc, should be taken in consideration. CoAR admitted that GAF's presence has been longer than CoAR in Baraki and Jaghatu, but CoAR has had a longer history' of presence in Wardak than ADA. Therefore, FAO should have given the clinics of Wardak to CoAR.

Decision: This issue will be an item of the agenda for the next meeting. For that meeting, heads of EU and FAO, director of CoAR, and directors of some other agencies will be specially invited to facilitate making the final decision.

NOTE: It is understood that EU representative will not be in town when the next meeting is scheduled. Therefore, discussion on the issue of Duplication of VFUs has to be postponed for another meeting and the special invitation be canceled. 


\section{ACTIVITY REPORT}

Afghanaid has presented its activity reports in veterinary sector to the sub-committee in Dari. Translation of the report is attached.

NEXT MEETING:

The next Veterinary Sub-committee meeting will be held one month from now on 27 March 1997 at 9:00 am in ACBAR office.

$\begin{array}{lll}\text { Chairman } & : & \text { Dr M A Salemi, TCP/FAO } \\ \text { Minutes } & : & \text { A Jawed Ludin, ACBAR }\end{array}$

The participants:

- M A Salemi

- Shah M Safi

- Eng Esmat

- Dr A Ghafoor

- Dr Zubiyda Popal

- Dr Saeed

- Dr Mehraban

- Dr Mohd Kazem

- Dr Zimeray

- Dr Alimuddin

- Dr M S Tahir

- Ahmad Jawed Ludin

Coordinator
Veterinary Coordinator
Admin Director
Director
Women Extensionist
Veterinary In-charge
National Manager
Veterinary Coordinator
Advisor
Veterinarian
Veterinary Coordinator
Information Officer

TCP/FAO

ARDA

ADA

GAF

DCA

COAR

FAO

PRB

PRB

Afghanaid

MADERA

ACBAR

Absent:

AFRANE, EU, MDC, OXFAM, RAFA and UNOPS. 


\section{AFGHANAID \\ Veterinary Project}

Report on activities (1 April - 15 December 199)

Afghanaid's veterinary project was started in 1996 in one province (Badakhshan) and six districts. Presently, these activities are going on.

\section{OBJECTIVE:}

a. Improving animal health and production by delivering veterinary services in village level.

b. Satisfying the requirement of veterinary personnel in the area.

c. Increasing public awareness and training BVWs.

\section{ACTIVITIES:}

1. BVW Training

After a survey and proper selections, from six districts (Argo, Gurm, Baharak, Sheghnan, Eshkashem and Wakhan) 27 persons were selected to be trained as BVWs. From the first three districts, 3 persons were selected from each districts (totally 9 people) and were put on a course of 28 days training.

For the second course, people were selected ( 6 persons from each district) from the last three districts (Sheghnan, Eshkashem and Wakhan). The trainees were provided with training certificate, kits, medicine and other supplies.

\section{Vaccination Programme}

The vaccine of Anthrax was carried out from 3 May to 25 May 1996 in Shewa plains. Shewa plains are used for pastures by livestock owners of Badakhshan, Takhar, Kunduz and Baghlan. 9435 goat and sheep and 1356 cows were vaccinated.

Further, vaccines, ie ASV, BQ, ETV and CCPP, were distributed to BVWs in their related villages and districts, who carried out vaccination of different animal diseases up to December 1996. Totally, 38196 goat and sheep and 2786 cows were vaccinated.

\section{Deworming}

Antihelmentic medicine has been given to a total of 5246 animals which include 3483 goats and sheep and 1736 cows, horses, donkeys, etc.

4. Treatment

A total of 4332 different animals, ie goat, sheep, cow, horse, donkey, etc have treated against different diseases.

\section{Awareness}

As Badakhshah is a mountainous and hard accessible province, and the people who own livestock are illiterate and live in remote areas, we planned to run awareness programme through our Community Development programme. People were taught the importance of vaccination, treatment, and better livestock management.

Dr Alimuddin Naseri

27 February 1997 


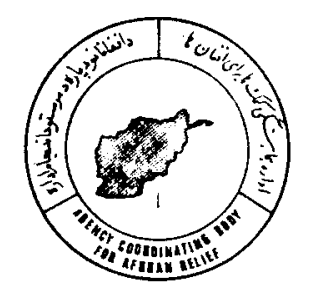

\section{VETERINARY SUB-COMMITTEE MEETING \\ 27 March 1997}

Chairman, Dr M A Salemi, opened the meeting by welcoming the participants. He thanked Mr $\mathrm{T} J$ Barker, Programme Manager FAO Livestock, for his interest in participating in the meeting.

1. Approval of the agenda

The agenda was approved.

2. summary of last meeting's minutes, and approval

ACBAR presented a summary of last meetings's minutes. Comments from the floor were as follow:

'DCA asked clarification if Dr Salemi, now being a UN related employee, could continue as chairman of the sub-committee. ACBAR was asked if this was valid according to the policy. ACBAR, in response, clarified that there is no policy restriction for UN employees to work as chairman for ACBAR's sectoral sub-committees and coordination groups.'

Commenting on UNDP's Poverty Eradication And community Empowerment (PEACE) programme, reported on by FAO in the last minutes, PRB expressed that they are happy to see, for the first time, a comprehensive programme is designed for 23 districts together. However, PRB was willing to know what activities will the programme include and what will be the real impacts. FAO, in response, stated that aim of the programme is to bring all the UNDP supported programmes in one district and thus to get a visibly existent impact. For example, FAO's livestock and crops programmes, UNOPS' community development programme, etc will be implemented together in a district. It was added that no specific criteria for selection of districts under this programme exists. However, ethnic, political, etc coverage will be intended and some other factors, ie poorest, remotest, etc will also be considered.

The minutes were approved.

\section{Announcements}

MADERA announced that their diagnostic lab in Jalalabad has started functioning. This lab, with two sections of bacteriology and parasitology, can provide diagnostic 
services to the public as well as to all agencies. MADERA added that they would like to request FAO for financial and material assistance to the lab.

FAO suggested that Dr Arzoo, in-charge of the lab, be invited for the next meeting to make a presentation on the lab and its functions.

DCA announced that they have allocation for local vaccine production in the budget for 1997. A Dutch vaccine production expert will be assigned to carry on a feasibility study in Afghanistan. The study will include assessment of the ways to start vaccine production in Afghanistan.

\section{Presentation on PIHAM Initiative, by FAO'}

The problem of veterinary workers' attitude towards farmers has been of significant concern within the veterinary aid providers. Due to the improper attitude ${ }^{2}$ attained by veterinarians and other veterinary workers, farmers usually refrained from getting and applying assistance. To improve the delivery of assistance, FAO ran extension programmes. However, no big improvements were made since the extension workers lacked proper communication skills. Obviously this was believed to be a world-wide problem and Afghanistan was not the only country facing it.

At the same time, an extension package was designed in UK to improve the ways of aid delivery and specially address the problem of attitudes. This package was termed as Animal Health \& Production Improvement Module (AHPIM). This package

was first given to FAO Afghanistan programme: for pilot
implementation.

Before implementing this extension programme, FAO with the technical cooperation of the institute in UK made necessary amendments to the programme in order to make it fit in the Afghanistan context. The abbreviation of the programme was changed from AHPIM to PIHAM, but with the same words. The personnel of this programme are called PIHAM initiators, not extension workers, to keep it away from any bad impression the farmers might have got towards the previous extension workers.

Special thanks are due to Mr Terrence $J$ Barker, Programme Manager, and Dr Baqi Meraban, National Programme Manager, FAO Livestock - Islamabad, for making the presentation in English and Dari languages.

The improper attitudes include being rude, imposing decisions on farmers, not involving farmers in finding solutions for problems, etc. 
A training course for PIHAM initiators was run by FAO in which 12 initiators ( 6 livestock and 6 crop production workers) were trained. This was a long term course (9 months) which included both class work as well as practical field work in villages.

The PIHAM initiative is based on the understanding that we should not tell farmers what to do but, instead, we should help farmers know what they do and what they can do. Aims of PIHAM are:

- To increase food production from livestock;

- to increase household income;

- to improve the delivery of livestock services to farmers; and

- to increase the income and sustainability of VFUs.

strategy of PIHAM is to build trust and confidence among farmers, help the farmers to find their problems as well as solutions for them, prepare the farmers to receive assistance properly, etc. The strategy is mainly based on certain principles and methods for implementation. (Attached please find the relevant handouts).

The way that the PIHAM initiators do their job is that one pair of initiators (one livestock and one crop production worker) first go to a target village; communicate the villagers and identify 9 farmers whom they continue to meet with regularly afterwards. These farmers are the ones who directly deal with the initiators on consultation and livestock problem solving services. There are certain criteria for selecting the 9 farmers and the factors to be considered are their status, wealth and skill. 3 farmers (with low, medium and high level) are identified for each of the factors, which altogether become 9 farmers. These farmers can act as representatives of the village who will participate in finding the problems as well as their solutions of the whole village. The PIHAM initiators, thus, help farmers to identify the problems they usually fall into and to solve the problems themselves by sharing experiences with the initiators.

Collection of data from the target villages is another important task undertaken by the initiators. This includes monitoring of the process and collecting necessary information for improvement of the process. The main considerations for data collection are:

Quantitative:

1. Progeny histories for baseline data

2. Monitoring key indicators

- mortality

- birth rate

- change in female held size 
3. VFU's level of income

Qualitative:

1. Farmers' comments on their experience of PIHAM

2. VFU staff's comments on PIHAM

Although PIHAM does not bring the farmers any material assistance, it is impressive to know that the farmers are usually very positive towards it. This is mainly because of the continuity and non-stop process of the programme.

As planned by FAO, the 12 PIHAM initiators will train veterinarians in all 255 FAO supported VFUs, and then, PIHAM will be implemented in most of Afghanistan.

In the last part of the presentation, Jawed Ludin from ACBAR, who had participated in a workshop on PIHAM organized by FAO on 3 March 1997 in Islamabad, added some comments, mainly, on the workshop. He said that the workshop discussed three topics: "Understanding PIHAM", "Sharing experience of PIHAM" and "Can PIHAM be applied to other UN programmes?". The participants were briefed on various aspects of the programme by the PIHAM initiators in several small group discussions. The question of whether or not PIHAM can be applied to other programmes caused a lot of discussion. However, at the end there was consensus that similar packages will be very effective if applied to other programmes. Jawed believed that PIHAM is very developmental oriented programme and is effective in building a local capacity within the community for developmental activities.

(Any questions regarding PIHAM, may be adaressed to FAO in the "l next meeting).

\section{Vaccine cost recovery policy}

The chairman requested the participants to be specific and avoid unnecessary discussions so that a conclusion could be achieved in this meeting.

FAO circulated a proposed vaccine cost recovery strategy; (a copy is attached for those who have not received it).

After a prolonged discussion, the general feeling of the meeting, with some notable exceptions, was not against vaccine cost recovery policy.

ATTITUDES OF AGENCIES:

Mr Barker, FAO, said that in 1996 EU paid no money for vaccine. Therefore, very meager resources, provided by UN and some other sources, existed. For 1997, EU has given DCA the 
fund for vaccine, however, there could be no guarantee of similar funding for the next years. The aid agencies in Afghanistan should do something to ensure that there will be vaccine even if donors no more pay for it. If this is the concern that farmers will not be able to afford it, there is a much more serious concern that farmers may sustain a big loss of their livestock in the next years. It was added that the proposed strategy indicates the best way of gradually setting a cost recovery policy. The money collected from vaccine sale will go to the Veterinary Services Association (VSA) which will be used for vaccine purchase whenever needed. Mr Barker further added that EU will also support the vaccine cost recovery policy.

DCA said that in principles they do not disagree with the policy. However, they have already secured funds for free distribution of vaccine in 1997, and revision of the protocol, as it takes time, will not be efficient. DCA added that they would follow the policy of vaccine cost recovery if their donors would support it. DCA suggested that on behalf of the Veterinary sub-committee FAO approach EU with a more comprehensive plan.

MADERA stated that their plan for 1997 has already been fixed and partly implemented, and there is little chance for revision of the policy. It was, however, added that director of MADERA should be invited, as, well as directors of other agencies, who can decide on policy revision for 98 . Dr Tahir, MADERA's representative, stated his personal attitude to be against the VCR policy, because vaccines have always been free and should be free.

COAR's concern was about the response of farmers against the policy. It was feared that this policy would affect farmers' interest for vaccination. CoAR, however, added that if their donors agree they will support the VCR policy.

GAF and ADA remained supportive of VCR policy.

\section{DECISION :}

- Mr Ewen Macleod from EU will be invited for the next meeting;

- directors of some agencies will also be invited;

- FAO will discuss it with EU before the next meeting; and

- the final decision in this regard will be sought in the next meeting.

\section{Activity reports}

PRB's report under the title of "Animal Health \& Livestock Production Program, Veterinary Services in Afghanistan" was circulated in the meeting. A copy is attached for those who have not receivied it. 


\section{Any other business}

The next meetings' agenda will include:

- Vaccine cost recovery policy;

- VFU duplication; as well as

- other items.

THE NEXT MEETING: The next Veterinary sub-committee meeting will take place on Monday 28 April 1997 at 9:00 am in ACBAR office. ${ }^{3}$

Chairman : Dr M A Salemi, FAO/TCP

Minutes : A Jawed Ludin, ACBAR

\section{The participants:}

- Dr M S Tahir

- M A Salemi

- Eng Esmat

- Shah M Safi

- T J Barker

- Dr Mehraban

- Dr A H Nasseri

- M Zakir

- Dr Samsoor

- Dr Ghulam Saeed

- Dr A Ghafoor

- Dr Zemeray

- Dr Nazir Ahmad

- Jawed Ludin
Livestock Coordinator

TCP Coordinator

Planning Director

Veterinary Coordinator

Programme Manager

National Manager

Deputy Manager

Head of Projects

Extension Coordinator

Veterinary In-charge

Director

Advisor

Monitor

Information officer
MADERA

FAO/TCP

ADA

ARDA

FAO

FAO

FAO

DCA

DCA

COAR

GAF

PRB

PRB

ACBAR

\section{Absent:}

Afghanaid, AFRANE, EU, MDC, OXFAM, RAFA and UNOPS.

NOTE : These minutes are circulated in draft. Any comments/corrections will be received in the next meeting. process, this meeting had to be scheduled on Monday not Thursday. 


\section{VETERINARY SUB-COMMITTEE \\ Monday 28 April 1997}

The participants

- M. A. Salemi (Chairman)

- Dr. Mohammad Kazem

- Dr. Zimerry

- Dr. Nazir Ahmad

- Dr. A. H. Nawroz

- Dr. T. Gurtner

- Mohammad Zakir

- Dr. Samsor

- Dr. A. Q. Samin

- Dr. Ghulam Saeed

- Shah Mohammad Safi

- Jean-Francois Cautain

- Anwar Zafari

- Eng. Esmat

- Dr. A. Ghafoor

- Dr. Mehraban

- Shafiq Ahmad
FAO/TCP Rinder Pest

PRB

PRB

PRB

ICRC

ICRC

DCA

DCA

COAR

COAR

ARDA

MADERA

AGHCO

ADA

GAF

FAO Livestock

ACBAR

i. Approval of the agenda and minutes of the last meeting

Both the agenda and minutes of the last meeting were approved in the absence of any comments.

ii. Announcements

DCA announced that a vaccine production expert will come to Pakistan this year to undertake a feasibility study in Afghanistan.

MADERA suggested. if DCA can facilitate a visit of the expert to their vaccine production laboratory in Jalalabad.

The Chairman pointed out that he understood the Ministry of Agriculture in Kabul has asked the agencies producing vaccine to contact them. The point was well noted by DCA.

ICRC announced that they might start some small scale veterinary projects in areas difficult, in terms of accessibility, for other agencies ie Panjshir, Shomali valley and Qal-i-Naw. Dr. Nawroz will be in Peshawar to contact the agencies and collect information. ICRC is on a very primarily stages and the type of work will be determined on a priority basis.

ICRC was suggested if they can consider Badakhshan as this area has been undeserved and malnutrition among the people is very obvious.

FAO announced that prevalence of PPR disease in the south, reported at the previous meeting, has now 
been confirmed. Furthermore, this disease has been found in the south-western and eastern Afghanistan as well as in the north of Kabul. All VFUs had been asked to collect samples of suspicious diseases and send them for examination.

Samples of PPR have been sent to England and the disease has been confirmed. The issue has been discussed with FAO Rome. Using Rinderpest vaccine has been advised for the disease both by FAO Rome and concerned Pakistani authorities. Pakistanis have used Rinderpest vaccine whenever PPR was prevalent in Pakistan. Moreover, an expert came from UK and recommended the same.

FAO did not get a good labratory response about the serum collected from vaccinated cattle against Rinderpest. Blood was collected from cattle on zero day and 21st day of vaccination. Antibody was produced only in $20-30 \%$ of the vaccinated cattle. Experts advised taht the prevalence of PPR might have prevented the vaccinated cattle to produce antibody against Rinderpest. Because, PPR and Rinderpest are similar viruses. Cattle affected by PPR do not show any symptoms.

Despite all these advice, FAO is still not so sure as to whether use the Rinderpest vaccine or not. They continue their investigations and have taken very strong measures.

Dr. Salemi explained the arcas he visited and found this disease. He provided FAO with a detailed technical report and could be made available to the interested individuals on request.

It was suggested that FAO conduct a study of this disease in the north and collect samples for examination. FAO was also advised for a serious consideration of the disease; very cautious approach; and enough vaccine supply. These points were noted by FAO.

In response of a question by MADERA, FAO said that vaccination for Rinderpest discase will be provided on an emergency basis, thus, the farmers will not have to pay.

FAO was thanked for the work they had done for this particular issue.

\section{iii. Vaccine cost recovery policy}

The issue was discussed at the last mecting. Majority of the participants were in favor of the policy. Some agencies stated that this issue has to be decided upon by the donors. Therefore, EU was invited to attend this meeting. Since EU was not present, no decision was made.

It was suggested that the floor be briefed on the objectives of the policy.

Dr. Mehraban from FAO gave some background infirmation on the issue and explained the reasons for the cost recovery. One of the main reasons for such a policy, according to FAO, was the sustainability
of the program and reducing dependency.

Taking account of the success of the charging policy for veterinary medicine, FAO was quite optimistic of the success of the cost recovery policy. FAO said that the policy would be introduced very slowly starting from $10 \%$.

There were two contradictory vicws among the members. Some were supporting the cost recovery, while others were opposing. The main reason for opposing this policy was because of the poor economical conditions of farmers in the country.

After discussing various aspects of the issuc and considering the explanation of DCA on how the moncy comes for vaccination; and the donors considerations; it was agreed that the agencies with non-UN 
funding meet separately and come up with recommendations.

These agencies will meet on Wednesday 7 May at 2:00 pm in ACBAR conference room. The members will be notified of any outcomes of the meeting before the next Veterinary Sub-committee meeting takes place.

It was suggested that Afghanaid, who also undertakes some veterinary activities, be invited to this meeting.

The need for a coordinated approach was underlined and the potential problems of different policies were highlighted.

Further discussions on the issue will be held at the next meeting. Once the issue is agreed among the members, the EU will then be approached.

iv. Duplication of VFUs

It was suggested that COAR, ADA and GAF set together and solve the duplication problems internally. A meeting of these agencies was scheduled for Friday 2 May 1997 at 9:00 am in ACBAR conference room. The outcome of the meeting will be reported back to the Sub-conmittee.

To prevent duplication of VFUs, ACBAR suggested if FAO can produce a map indicating exact locations of all the VFUs in the country.

FAO was kind enough to express its willingness for production of the map, provided the agencies furnish the required information. Further discussion on the issue will be held at the next meeting.

v. Activity report

No new activities have been reported.

vi. Any other business

THE NEXT VETERINARY SUB-COMMITTEE MEETING; WILL TAKE PLACE ON TIUURSDAY 29 MAY 1997 AT 9:00 AM IN ACBAR CONFERENCE ROOM.

The following agenda was requested for the next meeting:

i. $\quad$ Cost Recovery Policy:

- $\quad$ Report by the working group (agencies with non-UN funding); and

- Further discussion.

ii. Outcome of the meeting Re: Duplication problem

iii. Presentation by Dr. Arzo on Jalalabad Laboratory

The agenda will be separately circulated before the next meeting. 


\section{VETERINARY SUB-COMMITTEE \\ SUB-GROUP MEETING \\ Friday 2 May 1997}

The Veterinary Sub-committee in its meeting of 28 April discussed the duplication problems between ADA, CoAR and GAF. It was agreed that these agencies meet separately and solve the problem internally.

Based on this decision, these agencies met on 2 May and made the following agreements:

i. the agencies will continue their activities for the year 1997 as before;

ii. the ADA and CoAR field staff should call monthly coordination meeting in Sayed Abad, Wardak;

iii. the COAR and GAF field staff should call similar meetings in Jaghatu, Ghazni;

iv. the three agencies, while sending monitoring teams from the main offices, should monitor VFUs of each other. This should be aimed at improving veterinary services and encourage better coordination in the field; and

v. main offices of these three agencies will authorize the In-charge of their VFU'S to consider the followings:

a) implement the vaccination campaign in the right time -according to the decision of the ACBAR Veterinary Sub-committee;

b) decide on the medicine cost in consultation of the field staff of the other two agencies; and

c) cooperate with each other. Prescription given by one of the three agencies shall be issued with medicine by VFUs of the other two agencies.

The three agencies also agreed to follow any decisions made at the ACBAR Veterinary Subcommittee.

NOTE: These decisions, for information of the field staff, will be translated in Pushtu and Dari. 


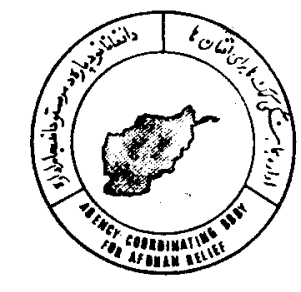

\section{د وترنرى فرعى كميته

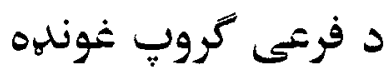

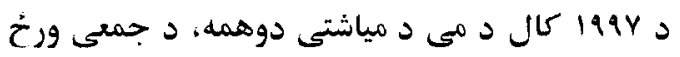

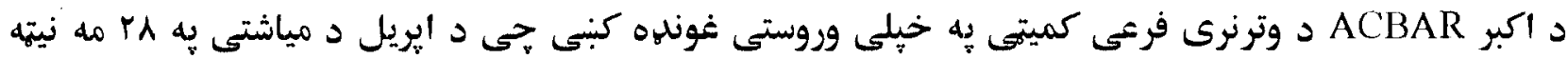

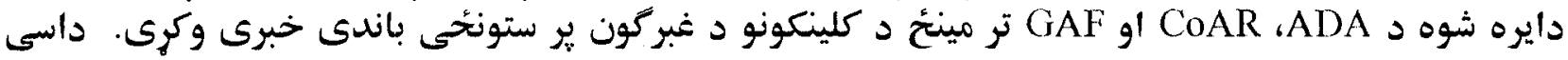

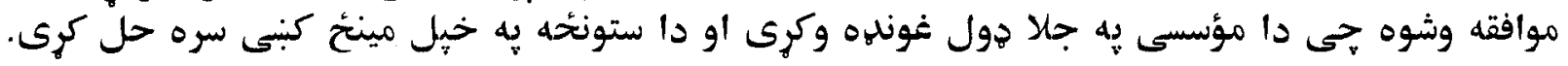

د دى فيصلى هي بنا، نومورو مؤسساتو د مي د مياشتى پٍه دوهمه نيته سره وكتل او لاندينى موافقى يحى سرته ورسولى:

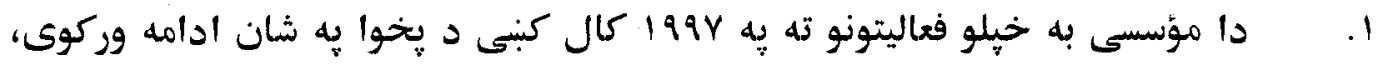

د ADA او CoAR د مؤسسو ساحوى كاركوونكى به د وردك ولايت د سيدآباد يه ولسوالى كبنى هره مياشت د انسجام غوندى دو دايروى،

مؤسسو ساحوى كاركوونكى به همداسى غونلهى د نيز ني ولايت د جنتو يه ولسوالى كبنى جوروى،

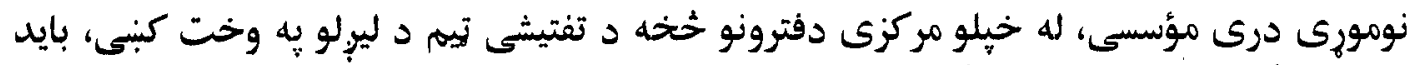

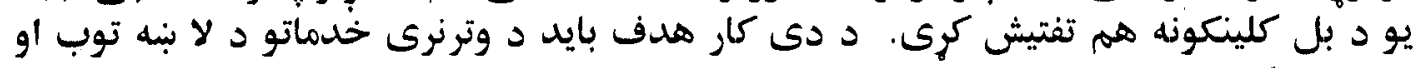

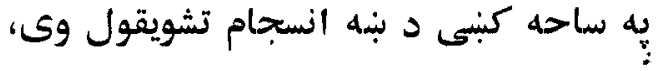

د نومورو دريو مؤسساتو مركزى دفترونه به د خهلو كلينكونو مسئولينو ته د لاندينيو كارونو

الف) د واكسين كمياين بايد د اكبر ACBAR د فيصلى مطابق يه تاكل شوى وخت سرته

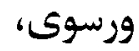

ب) د درملو بيه بايد د دوز نورو مؤسساتو د ساحوى كاركوونكو د مشورى سره سم وتاكى،

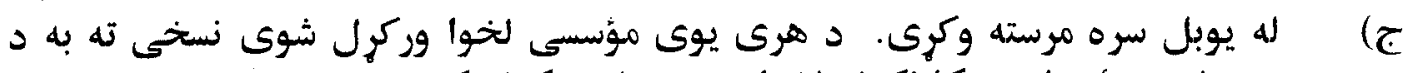

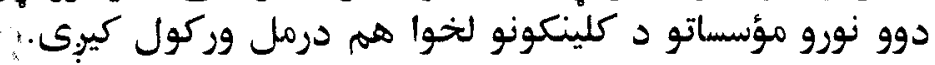

نومورو دريو مؤسساتو همداراز موافقه وكره جحى د اكبر ACBAR د وترنرى د فرعى كميتى تولى فيصلى به عملى كوى.

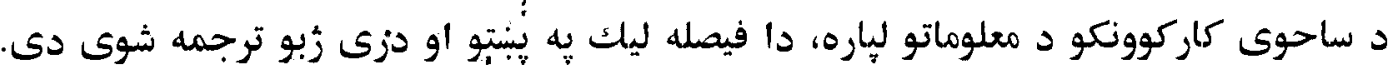

نوت: 


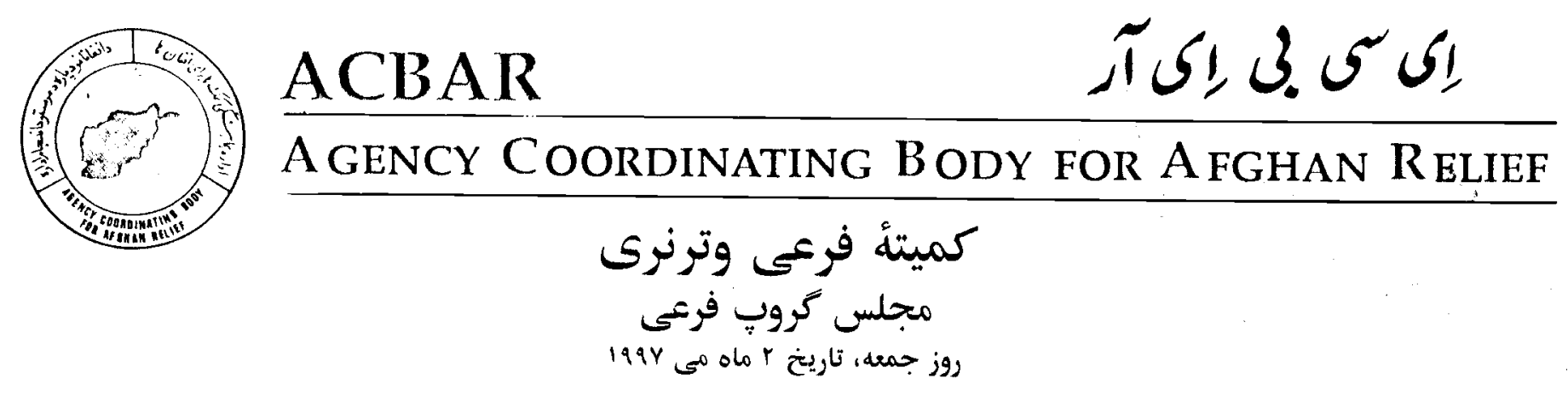

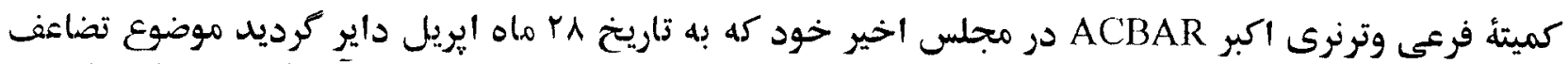

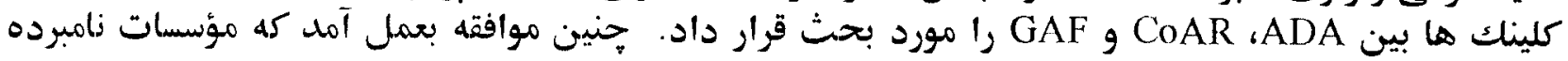

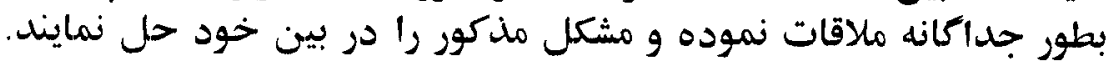

بر اساس اين فيصله، مؤسسات مذكور به تاريخ r مى ملاقات نمودند و توافقات ذيل را بعمل آوردند: 1. مؤسسات نامبرده به فحاليت هاى خود در سال 1999 مثل سابق ادامه خواهند داد،

r. عاركنان ساحوى مؤسسات COAR و ADA مجالس انسجام را طور ماهوار در ولسوالى سيدآباد ولايت وردك داير خواحي مؤهنات نمود،

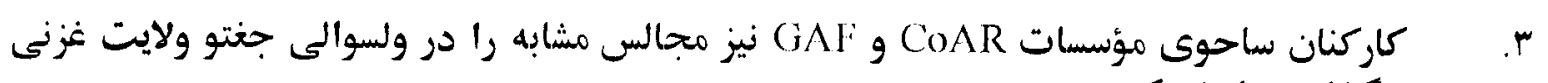

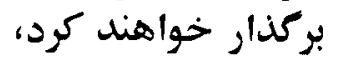

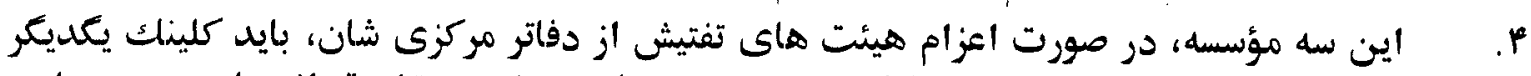

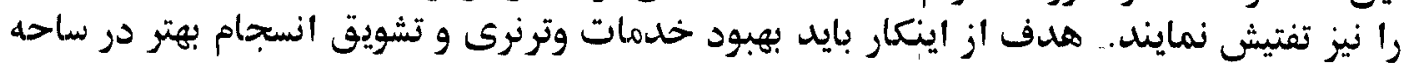
باشد،

ه. دفائر مركزى اين سه مؤسسه بايد به مسئولين كلينك هاى خود صلاحيت هاى آتى را اعطا نمايند: دفائ

الف) كمياين واكسيناسيون را به وقت مناسب آن مطابق فيصله اكبر ACBAR اجرا نمايند، ب) قيمت ادوييه را با مشورة كاركنان ساحوى دو مؤسسة ديكر تعيين نمايند،

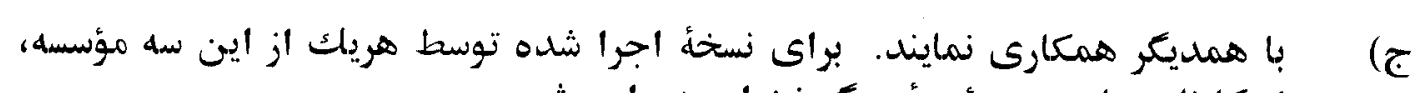

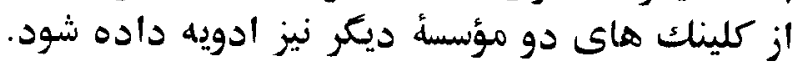

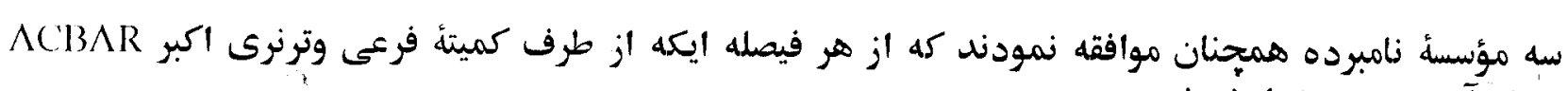

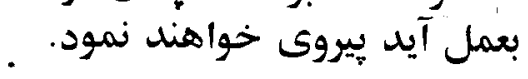

متن اين موافقتنامه، براى معلومات كاركنان ساحوى مؤسسات، به زبان هاى يشتو و درى ترجمه كرديده است. نوت: 


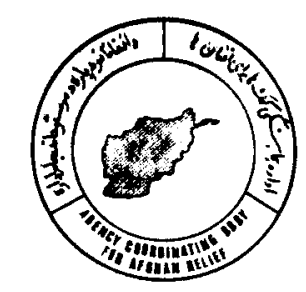

\section{VETERINARY SUB-COMMITTEE Sub-group Meeting \\ 7 May 1997}

The issue of vaccine cost recovery policy, proposed by fAo for I" application in Afghanistan, has stood un-decided for the last several meetings. This is mainly because of the difference in ideas about the policy.

The ACBAR Veterinary Sub-committee in its last meeting on 28 April 1997 decided that the agencies with non-UN funding meet separately and come up with solid recommendation about the policy.

Based on the decision, a meeting was held at 2:00 pm on 7 May 1997 in ACBAR office. The following people attended the meeting:

$\begin{array}{lll}\text { 1. } & \text { Kerry Jane } & \text { Afghanaid } \\ \text { 2. } & \text { Dr Qahar Samin } & \text { COAR } \\ \text { 3. } & \text { Dr Ghulam Saeed } & \text { COAR } \\ \text { 4. } & \text { Mohammad Zakir } & \text { DCA } \\ \text { 5. Jean-Francois Cautain } & \text { MADERA } \\ \text { 6. } & \text { A Jawed Ludin } & \text { ACBAR }\end{array}$

After a prolonged discussion, the following was, generally, agreed upon:

The above four agencies do not disagree, in principles, with the idea of vaccine cost recovery, specially on account of the sustainability of vaccination services. However, there are certain concerns which mainly relate to the implementation strategy of the policy. One of the main fear is that this policy will result in sizable reduction "in the number of vaccinated animals and so, will increase outbreak of diseases. Another concern is over the already signed protocols in 1997, the revision of which will take time. These concerns, however, are less likely to be a big problem.

According to the FAO proposed strategy for the policy, in 1997, the cost recovery will implemented in the northern Afghanistan only, with charging $10 \%$ of the total cost for only two vaccines. This may not require any changes in the programmes run by DCA, MADERA and COAR because they have no programme in the north. Afghanaid, with programmes in Badakhshan, will follow the cost recovery policy in'1997 by charging $10 \%$ of the cost. DCA, MADERA 
and COAR decided to consider implementing the policy in their programmes for 1998.

It was also decided that a similar meeting be arranged towards October/November 1997 to discuss the data and field observations collected from the northern provinces after implementing the cost recovery policy. The meeting will assess success of the policy and will come up with further recommendations. 


\section{VETERINARY SUB-COMMITTEE MEETING}

Thursday 29 May 1997

Chairman : Dr M Sabir Tahir, MADERA

Participants:

$\begin{array}{lll}\text { - } & \text { Dr M S Tahir } & \\ - & \text { Dr G Mahayuddin Arzo } & \text { MADERA } \\ \text { - } & \text { Dr A H Nawroz } & \text { ICRC } \\ \text { - } & \text { Dr A R Rashidi } & \text { ICRC } \\ \text { - } & \text { Eng Esmat } & \text { ADA } \\ \text { - } & \text { Terence J Barker } & \text { FAO } \\ \text { - } & \text { Dr Mehraban } & \text { FAO } \\ \text { - } & \text { Shah Mahmood Safi } & \text { ARDA } \\ - & \text { Dr Nazir Ahmad Sherzai } & \text { PRB } \\ \text { - Dr A Ghafoor } & \text { GAF } \\ \text { - } & \text { Mohammad Zakir } & \text { DCA } \\ \text { - } & \text { Ewen Macleod } & \text { EU } \\ \text { - Charles A MacFadden } & \text { ACBAR } \\ \text { - } & \text { Shafiq Ahmad Qarizada } & \text { ACBAR } \\ \text { - A Jawed Ludin } & \text { ACBAR }\end{array}$

Dr Salemi's apology was conveyed to the meeting by FAO. Dr Sabir Tahir presided over the meeting.

1. Approval of the agenda

The agenda was approved.

2. Summary of last meeting's minutes

ACBAR presented a summary of last meeting's minutes. The important discussions of last meeting were highlighted.

\section{Announcements}

FAO announced that a VSA has recently been set up in Kabul. This is the seventh association joining the VSA family. 76 veterinarians have so far joined this VSA. It was further announced that the Agriculture Ministry has approved the guidelines for VSA operation which have been given to the Ministry of Planning for further follow'up.

MADERA announced that based on a letter they had received from the Agriculture Ministry, they conducted a mission to Kabul to assess the feapibility of vaccine production by MADERA. 


\section{Vaccine Cost Recovery Policy}

\section{Report from the working group:}

DCA and ACBAR reported on the discussions and decisions that took place in the meeting of non-FAO funded agencies on 7 May 1997. Afghanaid, DCA, MADERA, COAR and ACBAR participated in that meeting. The cost recovery policy was supported in principles. However, some concerns over the implementation of the policy were also raised. It was agreed that the cost recovery be started in 1997 in the northern Afghanistan. Afghanaid, with activities in Badakhshan will follow the strategy proposed by FAO. The other agencies will consider implementing the policy in 1998. A special meeting was suggested to be organized in November 1997 in which the progress and outcome of the policy implementation will be assessed and plan for expansion of the policy will be made.

\section{Further discussion:}

MADERA stressed that the policy implementation should be carefully monitored so that any problems hindering the preventive veterinary health care would not happen.

A detailed strategy for vaccine cost recovery on vaccines prepared by FAO had been circulated to the sub-committee members. It outlined in details the contents of the policy. Some questions on the policy arose which were responded with reference to the strategy draft.

Mr Ewen Macleod, EC Programme Coordinator, noted that the European Commission had supported the procurement of animal vaccines for Afghanistan in 1995 and 1997. The objective had been to increase food security. So far this had been done using humanitarian aid instruments. The future: of this approach was uncertain and there was no guarantee that continued funding would be available. As such, the orientation towards cost recovery was viewed as a sensible way of building up the means for a minimum level of vaccination coverage whether donor contributions were forthcoming or not.

Commenting on the discussions on cost recovery policy recorded at previous ACBAR meetings, Mr Macleod noted that there had been a lack of economic analysis of its implications for the farmers. A detailed breakdown of the anticipated costs of vaccination to individual farmers would helpful in guiding reflection as to the financial viability of the initiative.

Mr Macleod stated that he would forward the FAO strategy document to the European Commission. He was confident that it would be acceptable in principles. As to the speed with which a cost recovery policy should be introduced, this would in practice be determined by how successfully it was implemented. The early phase would be carefully monitored as had been agreed by FAO. Field results would indicate whether the timetable was appropriate. 
Mr Charles MacFadden, ACBAR Executive Director, agreed that any funding from donors in the future cannot be guaranteed. Along with alternatives for sustainable veterinary programmes, steps should also be taken to reduce the dependency of farmers. He stressed on education of farmers on the need for vaccination.

In a rough calculation, FAO stated that a sheep costs $\$ 50$ to 80 while if the price of a vaccine is 5 cents and the farmer is charged for $20 \%$ of it, the total payable charge becomes 1 cent. The owner has to pay only 10 cents if his sheep is vaccinated against 10 diseases.

Mr Terence Barker, FAO Programme Manager, as a conclusion, said that the strategy and other relevant expressed details will be taken to the FAO office and they will review the programme where it needs readjustment. Mr Barker, suggested that EU would do the same.

Mr Charles MacFadden, stressed that this should become a strong policy of all UN and non-UN agencies involved in veterinary services. He added that ACBAR will encourage its members as well as non-member agencies to support the policy.

\section{Duplication of VFUs}

\section{Outcome of the involved agencies' meeting:}

ACBAR briefly reported on that meeting. Minutes of the meeting, also translated in the two local languages (Dari and Pushtul had already been circulated.

Comment from GAF: Baraki Barak district of Logar province, where a duplication of VFU between COAR and GAF exists has been left out of the minutes. It was agreed that the same decision be applied in this district.

FAO, concerning the different medicine prices in the VFUs, stressed as CoAR has funds for purchase and transportation of medicine, it should also make enough medicine available for VFUs of the other agency in a district. By selling the medicine on no subsidy, the prices of both VFUs will then become the same.

\section{Presentation by $\operatorname{Dr}$ Arzo on MADERA's Laboratory in Jalalabad}

MADERA circulated written presentation of the laboratory and its activities. It was followed by further explanations by Dr Arzo.

It was reported that the laboratory is committed to produce one mililion dozes! of the five ordinary vaccines for this year. However, for the next year it will double. 
MADERA asked FAO for any financial, equipment and material support to the laboratory. This request was noted by FAO.

\section{Any other business}

\section{ICRC's veterinary programme:}

Dr Nawroz, ICRC, was requested to inform the floor about their veterinary activities. He said that ICRC has newly started veterinary activities with special focus on the areas behind the conflict, based on ICRC's policy line. These new activities are still in the planning stage. Some areas have been surveyed. The activities will be launched next week.

ICRC agreed to report in details on their veterinary activities in the next meeting.

\section{FAO' map of VFUs:}

ACBAR circulated the map and lists of FAO's VFUs. It was asked if FAO could provide a map also containing the non-FAO VFUs in Afghanistan. FAO agreed to provide such maps provided that the different agencies provide their lists of VFUs.

THE NEXT Veterinary Sub-committee meeting will be held on Thursday 26 June 1997 at 9:00 am in ACBAR conference room. Agenda for the meeting will be circulated later.

End of the meeting.

A Jawed Ludin

Programme Officer, ACBAR

2 June 1997 


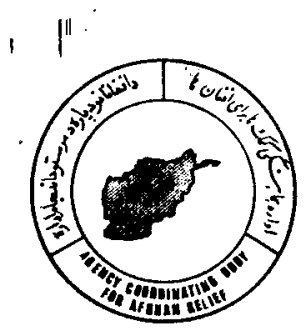

\section{VETERINARY SUB-COMMITTEE MEETING \\ 26 June 1997}

Chairman : Dr Sabir Tahir, MADERA

The participants:

$\begin{array}{ll}\text { - } & \text { Dr Sabir Tahir } \\ \text { - } & \text { Eng Esmat } \\ \text { - } & \text { D A Ghafoor } \\ \text { - } & \text { Dr Mohammad Kazem } \\ \text { - } & \text { Dr Ghulam Saeed } \\ \text { - } & \text { Dr A A Nasseri } \\ \text { - } & \text { Dr Sediqullah } \\ \text { - } & \text { Shah M Safi } \\ \text { - } & \text { Dr Zubaida Popal } \\ \text { - } & \text { Dr Nawroz } \\ \text { - } & \text { Dr A.R. Rashidi } \\ \text { - } & \text { Faqir Mohammad } \\ \text { - } & \text { Jawed Ludin }\end{array}$

Livestock Coordinator

Admin Director

Director

Veterinary Coordinator

Veterinary Coordinator

Deputy Manager

Asst Manager $T \& M$

Coordinator

Extension Worker

Veterinarian

Veterinarian

Programme Officer

Programme Officer

MADERA
ADA
GAF
PRB
COAR
FAO
FAO
EVC
DCA
ICRC
ICRC
ACBAR
ACBAR

MADERA

GAF

PRB

COAR

FAO

DCA

ICRC

ICRC

ACBAR

Due to absence of the chairman, Dr Sabir Tahir - MADERA, chaired

the meeting.

1. Approval of the agenda

The agenda was approved.

2. Summary and approval of last meeting's minutes

ACBAR summarized the highlights of last meeting's

discussions. The meeting was then asked for approval of the minutes. The minutes were approved.

3. Announcements

FAO, prior to making a couple of announcements, commented on the delay in starting the meetings. It was said that the participants should not come late so that meetings could start on time, exactly at 9:00.

It was:announced by FAO that a diagnostic.laboratory has been established within the FAO main of.fice premises in Islamabad. The laboratory enjoys computerized facilities, and is important for providing diagnostic facilities for any disease cases in Afghanistan, which previously used to be referred to laboratories here in Pakistan or elsewhere abroad. The laboratory will make a particular contribution to diagnosis of Rinderpest. Dr Osmani and Dr Dad Mohammad have the charge of the laboratory. 
to their clinic in Logar. He said to have seen the letter himself, but the letter was not signed by the minister. The letter, addressed to GAF and COAR, contained some advises from the ministry including:

- The agencies should not sell expired medicine;

- they should sell medicine cheaper than the market;

- they should not charge any fee for services; and

- etc.

The letter or some exact details on it, however, could not be provided.

This issue was raised as a concern. CoAR was requested to provide a copy of the letter possibly for the next meeting. It was said that ACBAR should deal with it if this issue is serious. ACBAR said that this may not be a major problem as such cases have been repeatedly experienced. CoAR agreed to try to obtain a copy of the letter from their clinic.

2

Dr Nawroz, ICRC, promised to make the presentation on their veterinary programme in the next meeting.

3.

FAO complained that many of the participants introduced by agencies to FAO's refresher training course in Kabul have not arrived yet to the course venue. As course has already been started, FAO stressed such delays should be avoided.

THE NEXT MEETING: The next Veterinary sub-committee meeting will take place on 24 July 1997 at 9:00 am in ACBAR office. Agenda for the meeting will be circulated later.

Having no other business, the meeting adjourned.

Ahmad Jawed Ludin

Programme Officer

ACBAR 
FAO also reported that both Dr Salemi and Dr Osmani, representing FAO Afghanistan, have been attending a 5 day" seminar on veterinary services in Oman, Jordan.

Shah Mohammad Safi, ARDA, announced that, in the process of establishing veterinary commissions supported by FAO, all the FAO supported VFUs of ARDA in the eastern region have been transferred to Eastern Veterinary Commission (EVC). Previously, similar commissions have been established in Kabul as well as Faryab. Chairman of the EVC is Dr Anbargul, ex-monitor of GAF, and its office is located in Jalalabad. Contacts to EVC can be made C/O GAF and FAO.

FAO added that the aim of establishing such commissions has been to strengthen privatization and to stress that veterinary services should be run by veterinary professionals.

GAF announced they have started concrete and baked bricked construction of their clinic buildings. This was started after the understanding that the previously mud-built buildings do not have good results and could not be used as a proper infrastructure in the future. EHSAN, with a quotation of Rs 110,000 per building, was sub-contracted for this construction project. So far, a couple of clinic buildings have been constructed in Khost.

MADERA, with regard GAF's above announcement, said that MADERA's construction section offers services for such projects. It was requested that MADERA be also involved in such projects in future.

DCA announced that the bulks of their imported vaccines from Europe arrived yesterday and were taken to stores. The vaccines include Sheeppox, Anthrax, Blackleg and NDV. FAO has been asked to arrange for distribution of the vaccine through their VFus.

4. Update on Vaccine Cost Recovery Policy (by FAO)

FAO said after this issue was finalized at the last meeting, there has been no major development. A letter has been sent to EU and they have been requested for an official answer. It was added that by arrival and distribution of DCA's vaccine, the cost recovery policy will be implemented in the northern Afghanistan. This will be closely monitored and reported upon.

\section{Any other business}

1 .

Dr Ghulam Saeed, CoAR, reported on an important issue. During his last visit to the field, he was informed about a letter that was allegedly sent by the Agriculture Ministry 


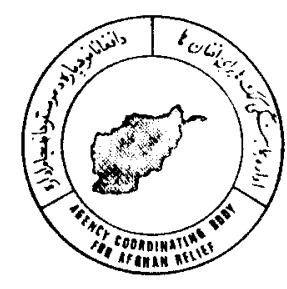

\section{VETERINARY SUB-COMMITTEE MEETING Thursday 24 July. 1997}

The chairman, Dr M Arif Salemi, welcomed the participants, and requested self introduction.

\section{i. Approval of the agenda}

Indicating the agenda, ACBAR explained that the item 5, "suggestions for the Sub-committee" has been included with the aim that the participants take part in looking for constructive suggestions for better future work.

ii. Summary and approval of last meeting's minutes

The highlights of last meeting's minutes were reviewed. The minutes were approved in absence of any comments.

\section{iii. Announcements}

FAO, based on news from their regional office in Jalalabad, reported outbreak of Rabies in Logar. Several animals as well as human beings have reportedly died from Rabies. FAO has immediately sent vaccine to Logar. A Rabies vaccination campaign is intended to be implemented there.

FAO also announced that $M r T J$ Barker has returned from his home-leave, and is available at FAO office in Islamabad.

PRB announced that Eng Kabir, PRB Director, has recently had a 15 day visit to Badakhshan and Takhar provinces. He visited PRBs VFUs there and has remarked his eye-witnesses as follow:

The environment of work and cooperation was very positive. Personnel of the clinics were present on their duties. Anthrax vaccination was being implemented, and both the farmers and veterinarians were satisfied with the results.

50 cows had reportedly died from Anthrax in different districts. There was a serious need for Anthrax vaccine. FAO is requested to make available enough vaccine to the VFUs in Takhar, Badakhshan and Kunduz.

- Cases of Rabies have been reported from several districts of Takhar. Using the available vaccine provided by FAO, the VFUs implemented Rabies vaccination, and the vaccinated dogs were red painted. However, there was a serious need for human vaccination. WHO has supplied vaccine to the Taluqan civil hospital, while there a serious need for vaccine in districts.

Dr Salemi, FAO/TCP, said that during a surveillance of Rabies in sabari district of Khost, "he faced with several cases of blackleg. The blackleg vaccine was not available in the district's VFU. GAF was requested to supply enough vaccine to the VFU. 
DCA announced that, in the process of distributing the newly arrived vaccines and submitting it to FAO, they have sent the first shipment to quetta. This batch included: 5437 deses of NDV, 906 bottles of ETV, 7249 doses of ASV, and 906 bottles of SPV 7 BQV

$\mathrm{DCA}^{\prime} \mathrm{s}$ Second announcement was regarding a new disease seen in Herat, which has caused paralysis in donkeys (seen also in horses). observations show that the diseased donkeys, while half paralyzed, continued to have very normal feeding, temperature and other conditions. In two weeks time, the disease has left 10 donkeys and 1 horse dead, as well as 4 to 5 donkeys sick. DCA has advised its staff. to use anti hecto parasites more than anti biotics. Spraying stables has also been advised.

Dr Samsoor, DCA, was requested to collect as more symptoms as possible and do a study on the new disease, and report on it to the next meeting. FAO requested Dr Samsoor to write an article for FAO's newsletter on the disease.

CoAR has supplied vaccines to its clinics in Logar, Wardak and Ghazni. 13000 doses of HSV, 13000 doses of ETV, 14000 doses of NDV and 92000 doses of ASV have been sent. CoAR also plans to start an anti Kecto parasite campaign which will mainly include spraying stables. They will use Tri Chlorophan for the spraying.

vi. ICRC presentation

Dr Harald Os, a Norwegian veterinarian, has been assigned by ICRC to set up a veterinary programme for ICRC in Afghanistan. He will be in Afghanistan for the next three months.

Dr Harald, who was participating in the meeting, conveyed the greetings of Dr Thomas Gutner and Dr Nawroz from ICRC and explained his activities since he has been to Afghanistan, very recently. He was able to travel to Panjsher, Mazar, Kabul, Jalalabad, etc. He visited offices and activities of some agencies in these provinces (eg FAO in Mazar, MADERA in Jalalabad, etc), and had opportunities to exchange views with veterinary workers. He would go to Islamabad the next day, where he wanted to meet with FAO. His purpose is to explore ways and requirements of effective and constructive venture for ICRC in the veterinary sector.

ICRC intends to include the veterinary component into its programmes in Afghanistan, by starting with veterinary activities, as yet planned, in Panjsher. ICRC makes a very cautious venture into the field of veterinary because there already exists a well organized system of service delivery. ICRC is afraid of competition and is, therefore, widely open for suggestions and advice. ICRC has the possibility of running a veterinary programme, but it should be run effectively. Dr Harald requested all the agencies to contact him if they have any suggestion/advice. Since the project has not practically started yet, Dr Harald will report in future on the specific activities undertaken.

Dr Salemi raised the concern of duplication of activities in Panjsher. Since there are FAO supported clinics operated by PRB in Panjsher, ICRC should discuss this issue with PRB.

MADERA suggested ICRC to use its available resources on vaccine production; which emerges to be a serious need in Afghanistan. Other services are le'ss recommendable for ICRC since there already is a large 
number of district based VFUs operating throughout the country. In this field ICRC will face no concern of duplication because production of
vaccine is largely needed.

It was also suggested from the floor that the central Afghanistan, ie Bamyan, Farah, .... mainly lack veterinary services. ICRC, therefore, can select these areas for their programme.

FAO appreciated ICRC's intention of working in the field of veterinary. Veterinary services have a definite history of continuance in Afghanistan. However, many trends have recently been reviance in changed. ICRC will need to make itself recently been reviewed and aware of the standards and suggested that ICRC ICRC's activities may be competition/duplo may be channeled in proper direction, and any fear of ICRC should ensure regular veterinary sub-committee.

Thanking Dr Harald for sharing views with the floor, the chairman welcomed ICRC to the ACBAR Veterinary Sub-committee and hoped that both the sub-committee and ICRC will benefit from cooperating with each
other.

v. Suggestions for the sub-committee

FAO suggested the followings:

1. Security update should be a fixed item in the agenda of every

2. gender issues/gender aspects of activities should also be focused
on in the discussions.

ADA said the Veterinary Sub-committee has proved to be very effective, and deserves compliments. Provided that there is no question of time limit, some outstanding issues, other than veterinary activities, should be related in general to issues, though irrelevant to veterinary, can conflict management (CPAU) activities. The formation of a network for example. It was requested a number of Afghans was mentioned, as an should be included in the agend a brief presentation on the network

MADERA suggested that, as it used in the past, activity presentation by certain agencies should be included in the agenda. Two or three for the next meeting.

EVC, besides some other remarks, suggested that small regional access to and use. more updated.

iv. Any other business

AGRICULTURE DEPARTMENTS'S LETTER TO COAR COAR had been able to obtain the original clinic in Logar. Copies of the letter of the letter from their participants. It was suggested that letter were circulated to the serious. After some discussion that such issues need to be taken COAR and GAF, who have received around this issue, it was agreed that 
to the Department of Agriculture, Logar, explaining the policy that the agencies follow. This issue will be followed up in future if needed.

\section{ASSOCIATION OF VETERINARIANS}

Dr saeed, COAR, said that the Afghan veterinarians should get together and set up an association, which may not only bring them together and encourage cooperation, but may also be in a position to defend their rights, and assist them in various areas eg employment, etc.

Many agencies from the floor, however, believed that the current UVSA (Umbrella of Veterinary Services Associations) is, in fact, an association of veterinarians, which has been entirely set up with developmental norms.

\section{BUYING VACCINE FROM FAO}

MADERA said that they have been using mostly pakistani vaccines. However, MADERA would now like to buy, if possible, some vaccines from FAO. The required vaccine will be SPV, BQV (each 20000 doses) and NDV (50000 doses). FAO, in response, asked MADERA to approach FAO with

formal request.

GLOBAL RINDERPEST ERADICATION WORKSHOP

Dr Salemi, who had attended, together with Dr Osmani, the 5 day workshop on Global Eradication of Rinderpest, held in Oman, Jordan, briefed the floor on the workshop and its outcome. The workshop, co-sponsored by FAO and International Institute of Atomic Energy, was participated by representatives from many, mainly, Asian countries.

\section{THE NEXT MEETING}

The next Veterinary Sub-committee meeting will take place on 28 August 1997 at 9:00 in ACBAR office.

\section{AGENDA FOR THE NEXT MEETING}

Beside its fixed items, the agenda will include the follow points:

- Security update;

- update by ICRC;

- presentation on veterinary activities, by ADA

- presentation on livestock improvement, by $\mathrm{Dr} M \mathrm{~A}$ Behsoodi, PRB;

- presentation on the new disease in Herat, by Dr Samsoor, DCA; and

- presentation on the CPAU Network, by ACBAR.

Chairman : Dr M A Salemi, FAO/TCP

Minutes : Faqir Mohammad, ACBAR

The participants:

M A Salemi

Dr Attaullah

Dr Samsoor

Eng Behsoodi

Dr zimeray

Dr G Saeed

Dr A A Nasseri

DR Anbergul

Eng Esmatullah

Dr Ahmadi

Dr M S Tahir

Harald Os

A Jawed Ludin

Faqir Mohammad
National Coordinator

Veterinary Supervisor

Extension Coordinator

Animal Husbandrest

Advisor

Veterinary Coordinator

Deputy National Manager

Chairman

Planning Director

Veterinarian

Livestock Coordinator

Veterinarian

Programme officer

Programme Officer

FAO/TCP
GAF
DCA
PRB
PRB
COAR
FAO
EVC
ADA
MDC
MADERA
ICRC
ACBAR
ACBAR




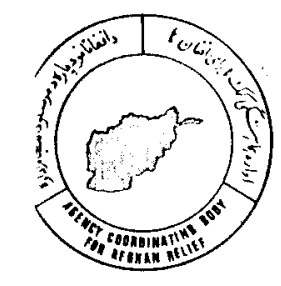

\section{VETERINARY SUB-COMMITTEE MEETING 28 AUGUST 1997}

1. Approval of the agenda and minutes of the last meeting:

a) The agenda:

Approved.

b) The minutes:

The chairman, for information of the members, presented summary of the issues discussed at the last meeting.

The following corrections were made:

date of the minutes of the last meeting should read 24 July 1997.

all 'doses' in Page two, paragraph one, line three and four should read 'bottles'.

paragraph 4, page 2 should read as follows:

"COAR has supplied vaccines to its clinics in Logar, Wardak and Ghazni. 13000 doses of HSV, 13000 doses of BQV, 40000 doses of NDV and 192000 doses of ASV has been sent. COAR also plans to start an anti ecto-parasites campaign which will mainly include spraying stables. They will use Trichlorophan for the spraying."

2. Announcements :

Rabies reported from Kandahar city. As many as 50 people and a cow were bitten.

DCA informed the floor of the amount of animal vaccines they received and the, amount they issued to FAO; sheet is attached.

3. Security update by ACBAR

The ACBAR Program Manager, who recently returned from Kabul, briefed the flloor on the current situation in Kabul and in some provinces. Part of the UN Weakly Update, which gave information on the front lines, was also read out to the members.

ACBAR suggested that members coming from different areas should brief the floor on the situation.

It was reported that a member of the sub-committee was arrested by the Taliban and badly beaten up in Maidan shahr. 
Dr. Nawroz explained the ICRC Veterinary Action Plan for $1997 / 98$ and answered questions raised by the members. A copy of the plan is attached.

ICRC was suggested if they can consider some veterinary activities in Bamyan Province.

5. Activity presentation by $A D A$

Eng. Esmatullah, as decided by the sub-committee, first explained the overall activities of the agency and then the veterinary services they provide. A handout was circulated to the participants; copy is attached.

ADA suggested if agencies can dig water ponds in different areas of Afghanistan. Lack of water ponds in Afghanistan seemed to be a big problem for livestock.

Dr. Mehraban from FAO stated that they are currently considering a cost effective fishing project for Afghanistan. Experts have been sent to Afghanistan to conduct a survey. The experts recommended to start with simple fishing project.

A small pilot project of finger-ling fish will be started. People are encouraged to do the project on their own. FAO will only provide technical expertise. Some 1500 finger-ling will be imported this year. The marketing aspect of the project had also been worked out.

Next year FAO will buy the fish from the people and sell them to those excavating their own ponds. People in Kandahar were looking forward to the project, when it was discussed with them in detail.

ICRC suggested FAO to make sure the imported fishes are not sick.

6. Presentation on livestock improvement - Eng. Behsoodi, PRB Eng. Behsoodi started his presentation by giving some background information and presented some facts and figures.

In conclusion, he suggested the Artificial Insemination (AI) as a quickest and economical way to improve cow generation in Afghanistan. Establishment of AI Stations in the Provinces can, in four years time, increase four times milk production and two times meat production.

Taking account of the above analysis, PRB with the technical and financial assistance of the UN is planning to establish such a center in Kabul and then expand it to the provinces. $\mathrm{PRB}$ also plans to establish dairy process center in the future.

To improve the livestock situation in Afghanistan, 
rehabilitation of pastures was also requested. The importance of other services ie vaccination, management, marketing, etc. can also play a significant role in improvement of livestock situation in Afghanistan, PRB concluded.

7. Presentation on the new diseases in Herat - Dr. Samsoor, DCA DR. Samsoor informed the members of a disease in Kohsan District of Herat Province. So far 8 donkeys were affected by the disease and five died. The affected donkeys had no fever and were eating very well just before their death.

This happened only in a small village. Dr. Samsoor guessed, taking account of some signs in the donkeys, three different diseases. The issue was discussed with the Agriculture Department of the Province and the farmers were given some advice.

According to the latest reports from the field, the disease has now been stopped. Pictures of the dead donkeys were shown to the participants.

8. Presentation of CPAU Network - Abdul Raziq, ADA

The floor was briefed on the history of the Network, activities undertaken by the Network so far and the future plans of the Network. Questions raised were answered.

Handouts were circulated to the participants.

9. Any other business

THE NEXT VETERINARY SUB-COMMITTEE MEETING WILL BE HELD ON MONDAY 29 SEPTEMBER 1997 AT 9:00 AM IN ACBAR CONFERENCE ROOM. THE AGENDA WILL BE CIRCULATED LATER.

The participants :

$\begin{array}{lll}\text { - M. A. Salemi (Chairman) } & \text { FAO/TCP/Rinderpest } \\ \text { - } & \text { Dr. Harald } & \text { ICRC } \\ \text { - } & \text { Dr. Nawroz } & \text { ICRC } \\ \text { - Eng. Behsoodi } & \text { PRB } \\ \text { - Dr. M. Kazem } & \text { PRB } \\ \text { - Lex Ros } & \text { DCA } \\ \text { - Dr. Samsoor } & \text { DCA } \\ \text { - Dr. Shamshad Qurishi } & \text { DCA } \\ \text { - } & \text { Shah Mahmood Safi } & \text { EVC } \\ \text { - Sardar Mohammad } & \text { UVSA } \\ \text { - Dr. A. Ghafoor } & \text { GAF } \\ \text { - Eng. Esmatullah } & \text { ADA } \\ \text { - Abdul:Raziq } & \text { ADA } \\ \text { - Dr. A. B. Mehraban } & \text { FAO-Livestock } \\ \text { - Dr. M. S. Tahir } & \text { MADERA } \\ \text { - Shafiq Ahmad } & \text { ACBAR } \\ \text { - Faqir Mohammad } & \text { ACBAR }\end{array}$

Minutes: $\quad$ Faqir Mohammad 


\author{
VETERINARY SUB COMMITTEE MEETING \\ 29 SEPTEMBER 1997
}

i. Approval of the agenda

It was suggested by the floor that the recommendation of

Para vet problems inside Afghanistan and addition of skim milk in the production of NDV vaccine should be discussed under General update.

It was also suggested by the chairman that the

Duplication problems may be discussed in the presence of the concerned donor agencies.

After introduction of the participants and the agenda, one more item the "Announcement" is added in agenda the meeting was started at 9:15 am.

ii Summery and approval of the last minutes

The minutes were summarized by the chairman and only a small correction was made in the minutes. The last page point 7, second and third line should read 8 donkeys dead and 5 affected. The minutes were then approved.

\title{
iii. Announcements
}

MADERA for the first time produced 6000 doses of ATV vaccine for their clinics and will be distributed in their field of activity, especially in Kunar province from, first october 1997.

Some questions were asked about the vaccine production laboratory. MADERA will give detail report on the issue at the next meeting. Dr. Arzo will also be invited at the next meeting to discuss about vaccine production. Other agencies also suggested vaccine distribution to their clinics by MADERA and they will check the result of field efficacy.

The chairman suggested the participation of the Veterinary Sub-committee members, FAO, ICRC and other NGOs working in the field of veterinary to the inauguration ceremony of the vaccine production Laboratory of MADERA in Jalalabad as announced by MADERA.

EVC would like to establish BVW courses in some districts of Laghman province. They shared the idea with MADERA and would like to discuss it with FAO too.

iii. GENERAL UPDATE 
DCA would like to inform the participants through a handout about vaccine distributed to FAO offices during september 1997. Please find attached a copy of the handout.

DCA suggested FAO if they can be given vaccine for their training centers and clinics in Kabul rather than Peshawar.

EVC will donate some 2400 empty bottles of 50 ML and 100 ML to MADERA for their vaccine production laboratory.

EVC raised the addition of the skim milk in production of the NDV vaccine and asked question about the benefit. However, he was advised that he has the manufacturers description to be followed.

DCA's ninth edition veterinary magazine was published. Copies were distributed to the participants. Comments would be welcomed.

\section{Paiham Training Program}

GAF discussed the matter of Paiham training program had trained about 12 people in 4 courses during 1996 and in one course in 1997. Two women were among the trainees. These trainees will work in the field and train more people. Two people, who were introduced for training to Paiham by MADERA, are now working in Helmand.

MDC has a simple diagnostic laboratory with their sub-offices. The dogs were previously imported from abroad, but now they are breading here. Some 10 dogs have been trained in Peshawar and sent to Afghanistan for operation.

\section{Graduate paravets}

DCA complained that three paravets graduated in Peshawar and two graduated inside Afghanistan are looking for job. NGOs were requested to consider job for them.

The chairman requested the NGOs to consider the employment of the para vets before introducing them for training. It was suggested by ICRC that a group of professional people from ACBAR veterinary sub-committee together with FAO should be selected to control the employments.

Annual meeting of the veterinary union was suggested to discuss medicine standardization and utilization in the field.

Privatization of the veterinary clinics by same paravets as discussed by the floor was decided to be included in the agenda of the next Veterinary sub-Committee meeting. 


\section{Milk production - PRB}

PRB give a detailed presentation on the subject. Please find attached a copy of the presentation.

MADERA suggested that assistant doctors should be trained instead of paravetes as their employment will be secured even if their is a stable gornament formed in Afghanistan.

DCA stated that the Embassy of Holland has agreed to promote paravet training centers to institute.

\section{Any other Business}

54116 US \$ worth BVW kits will be bought by FAO through Vet association. As NGOs have been funded through FAO they can get these kits from associations for its distribution to their field.

DCA Kabul suggested that if ACBAR's veterinary coordination meetings be sometimes held inside Afghanistan. The floor decided that ACBAR's regulation are to be applicable.

The next Veterinary sub-committee meeting will be held on Wednesday 29 October 1997 at 9:00 am.

\section{The participants}

- Dr. M. A. Saleemi (Chairman)

- Dr. Rashidi

- Dr. Nawroz

- A. H. Hatami

- Eng. Behsoodi

- Dr. Nazir. A. Sherzai

- Dr. Anbar Gul

- Dr. M. Tahir Oriakhail

- Dr. Samsoor

- Dr. A. Ghafoor

- Dr. Sardar

- Dr. M. S. Tahir

- Br. Wahida Azeme

Minutes: Faqir Mohammad

FAO/TCP/Rinder Pest ICRC

ICRC

MDC

PRB

PRB

EVC

DCA Kabul

$D C A$

GAF/UVSA

UVSA

MADERA

Observer

ACBAR 


\section{DUTCH COMMITTEE FOR AFGHANISTAN}
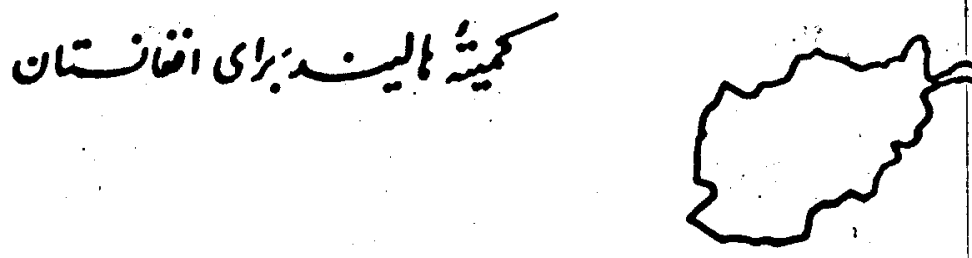

Date : September 29, 1997

To : Veterinary Coordination Committee (ACBAR)

From : Muhammad Zakir

Head of project support office

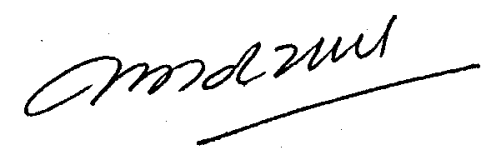

Subject: Animal vaccine distribution

Dear Colleagues,

Dutch Committee for, Afghanistan would like to inform you about distribution of vaccines during September 1997 to FAO.

\begin{tabular}{|c|c|c|c|c|c|c|c|c|}
\hline & & VACCINES & SUED TO & OO OFFICES & IN 1997 & & & \\
\hline $8 N$ & FAO-OFFICES & $\begin{array}{l}\text { NDV } 100 \\
\text { DOSE/VIAL }\end{array}$ & $\begin{array}{l}\text { BQV } 100 \\
\text { DOSE/VL }\end{array}$ & $\begin{array}{l}\text { ASV } 200 \\
\text { DOSE } / 100 \\
\text { ML VIAL }\end{array}$ & $\begin{array}{l}\text { SPV } 100 \\
\text { DOSE/VL }\end{array}$ & $\begin{array}{l}\text { DILUENT } \\
100 \mathrm{ML}\end{array}$ & $\begin{array}{l}\text { HSV } 100 \\
\text { DOSE/VIAL }\end{array}$ & ETV \\
\hline 1 & QUETTA & & & & & & 302 & 2165 \\
\hline \multirow[t]{2}{*}{2} & HERAT & 1830 & 457 & 1830 & 305 & 305 & 152 & 0 \\
\hline & Total & 1830 & 457 & 1630 & 305 & 305 & 454 & 2165 \\
\hline
\end{tabular}

With kind regards.

\section{Postal Address}

University Post Office

Box No. 792

Peshawar - Pakistan
Fax

$0521-840258$
Bank

Grindlays Bank

Peshawar

AVC 11313-55678009 


\title{
Pamir Reconstruction Bureau (PRB) Animal Health \& Livestock Production Section
}

\author{
Re-establishment of Dairy Plant in Kabul city
}

\section{Introduction:}

Milk and dairy bi-products due to its chemical combination is said to be one of the valuable product and there are different essential elements in the milk, such as different types of minerals, Faty-acids, Amino-acids, Sugar, Vitamins and other important elements required to build-up human body, especially to newly born children and their mothers.

\section{Chemical combination of milk:}

There are two basic elements in the milk, water and dry matters (combination of Fat, Albumin, Sugar and minerals). The percentage amount of these two elements present in milk are based on genetical types and varieties of animal, food quality management, ecology and climatic condition and other factors would differ. It means if amount of water percentage (90-83\%) is in changing condition than the amount of dry matters would (10-17\%) also change in that condition. But an average amount of water $(87 \%)$ and $(13 \%)$ dry matter is the basic combination of milk which is normally accepted and plays an important role in dieting. Detailed information concerning content of basic element in the milk of different animals are given in the attachment (1) and (2) of the report.

\section{Tresent situation and justification:}

Based on the survey conducted in Kabul province, emphasizes that the long distance of Kabul surrounding due to weak transportation linked to Kabul, farmers are facing problem of transporting their surplus milk to Kabul. Only a limited number of farmers who are to some extent close to Kabul are able to sell the surplus milk to Kabul market. The amount brought to the city is insufficient and on the other hand it is distributed un-hygienically with fluctuated price. This unhygienic quality affects growth and even results deficiency problem in the children.

Lack of proper management and improved marketing systems has influenced the supply and demand for animal and dairy products.

Factors affecting improvements on quality and quantity of products are:

1. Genetical improved type of animal.

Improvement of profylatic treatment and health sanitary condition of animal.

Increasing the knowledge and experience of farmers.

In view of taking into consideration the strategy of PRB aims to facilitate the condition favorable to promote veterinary and zo-technique services in order to make the farming families self sufficient, through effective measures to increase the production level. Considering the need and requirements of the farmers. It is recommended that first priority may be given to Kabul to develop artificial insemination center and a dairy processing plant in Kabul and then after to other provinces of the country. 
Based on our technical analysis, under present condition about (1-3) MT of fresh milk can be collected from localities close to Kabul. The matter has been already discussed with livestock owners in many districts and villages around Kabul. They appreciated the ideas and requested for an immediate action. Based on the figures collected from the livestock owners it can be stated that at present there are about (1000-1200) dairy cows in the surrounding areas of Kabul, they may produce about (2-3) MT of milk/day. The survey report also adds that in order to improve the livestock production the owners of the farms are proposing the following problems to be solved.

1. There are no artificial insemination centers.

2. Pastures have been converted to residents.

3. No marketing facilities for their surplus milk to be sold.

4. There are no transportation facilities.

Regarding the artificial insemination a proposal has already been forwarded to FAO livestock production.

To re-establish dairy plant in Kabul financial assistance is required = US $\$ 104,881$

\section{Working program:}

Installation of equipment

2. Arrange meeting with livestock owners to discuss problem if created during activities.

3. Milk and other items to be procured/daily.

The efficiency of the project based on analytical data obtained can be presented as follows:

1. Efficiency of the project based on volume of capital investment $=42.5 \%$

2. Efficiency of the project based on expenses $=84.6 \%$

13. Duration for self sufficiency of the project would be 2 years and 4 months.

4. Efficiency coefficient $=0.425 \%$

Hope that FAO livestock would support this project of vital importance to Kabul citizens and finance its implementation, considering the development and improvement in the quality and quantity of livestock products. PRB will have the opportunity to support technically its implementation. 


\section{VETERINARY SUB-COMMITTEE MEETING Wednesday 29 October 1997}

i. Approval of the agenda

The agenda was approved in the absence of any comments.

ii. Summery of the last meetings minutes

The minutes of the last meeting were summarized by the chairman and some small corrections were made in the minutes.

Page 1, under announcements 6000 doses of ATV should read 164000 doses of ETV vaccine.

Page 2, Paragraph 6: 'Paiham' should read 'Piham'; 4 courses should read 3 courses; and more people should read 48 .

Page 3, second Paragraph should read DCA has agreed with the Government of Holland to promote paravete training centers to institutes.

\section{iii. Announcements}

MADERA's vaccine production laboratory's inauguration ceremony will be held on Thursday 6 November 1997 at 11:00 am in Jalalabad. Invitation will be circulated later.

MADERA had been requested by DACAAR to train 2 mid paravet in Salaw village, Laghman. Since DACAAR has not been involved in veterinary activities, it was decided that an authorized person from DACAAR be invited to clarify the issue.

DCA circulated"an updated list regarding receipt and issue of vaccines up to October 1997. Please find a copy attached. It was also announced that $\mathrm{Mr}$. Steve Blakeway is expected to arrive on 9 November 1997. For further information please see the attached letter.

EVC reported some vaccine reactions in Bati kot district and Kunar province. The agency was requested. to collect details.

GAF announced the memberships of the UVSA's as follow:

$\begin{array}{ll}\text { Agency } & \text { Number of people } \\ \text { PRB } & 85\end{array}$




\begin{tabular}{lc} 
GAF & 61 \\
EVC & 48 \\
BCC & 44 \\
ADA & 17 \\
KBS & 16 \\
FVC & 13 \\
VARA & 13 \\
MADERA & 11 \\
FAO & 9 \\
MCI & 9 \\
VTC & 4 \\
VCA & 1 \\
Independant Vet. & 6 \\
\hline Total & 337
\end{tabular}

It was said that the membership fee and money for purchasing medicines and equipenents and BVW kits should be paid in advance. The ordered materials will be received sometime during next 'month.

iv. Presentation by MADERA

The presentation on vaccine production laboratory was made by Dr. Arzo. Please find a copy of his presentation attached.

v. General update

\section{A: Security:}

It was reported that Jalalabad Kunar road is closed even for public transportation for the last couple of weeks. People were traveling through Khas Kunar. Negotiation is going on to open the road for public transportation.

ICRC traveled from Jabal-u-Saraj to Mazar by taxi. No problem was experienced and the situation was normal.

PRB reported that the road between Kunduz and Takhar has been closed till last week. Staff are asking their salaries to be transferred to UVSA. It was also underlined that people urgently need medicine. However, some paravets from faizabad bought medicine from the market. It was suggested if the association could provide them medicine.

\section{B: Activity}

ICRC has rehabilitated two clinics in Khairkhana, Kabul and Khawak Panjshir.

Khairkhana clinic: two weeks ago about 5000 doses of vaccine have been provided to the clinic. Two people are working in this clinic. "FAO policy is followed in the clinic. 
Khawak clinic: this clinic has received some 25 cases in 5 days. ICRC considers that this clinic is located in a completely new area while PRB claims that this clinic is located in PRB's Hazara area. It was decided that the problem between ICRC and PRB should be seperatly discussed and solved.

In reply to a question FAO explained that usually there is one clinic in a district. However, in special circumstances ie big number of animals in a district, two or more clinics can be recommended.

ICRC was requested to rehabilitate Kabul vaccine production Laboratory, if possible.

ICRC said that they are going to conduct a survey on nomads/livestock. FAO also has a similar plan. This issue will be discussed at the next meeting.

Next Sub-committee meeting will be held on Thursday 27 November 1997 .

\section{The participants}

$\begin{array}{lll}\text { - } & \text { Dr. Rashidi } & \text { ICRC } \\ \text { - } & \text { Dr. Nawroz } & \text { ICRC } \\ \text { - } & \text { Dr. Hatami } & \text { MDC } \\ \text { - } & \text { Dr. Nazir Ahmad } & \text { PRB } \\ \text { - } & \text { Dr. Anbar gul } & \text { EVC } \\ \text { - Dr.Sediquilah } & \text { FAO } \\ \text { - } & \text { Dr. A. Ghafoor } & \text { GAF\UVSA } \\ \text { - } & \text { Dr. Ghulam Saeed } & \text { COAR } \\ \text { - } & \text { Eng. Esmatullah } & \text { ADA } \\ \text { - } & \text { Dr. Samsoor } & \text { DCA } \\ \text { - Dr. G. M. Arzo } & \text { MADERA } \\ \text { - Dr. M. S. Tahir } & \text { MADERA }\end{array}$

Chaired by: Dr. M. A. Salemi

Minutes by: Faqir Mohammad 


\section{VETERINARY SUB-COMMITTEE MEETING THURSDAY 27 NOVEMBER 1997}

The participants:

- Dr.Mehraban

- M. J. Emal

- Dr. Samsoor

- Dr. Ghulam saeed

- Dr. Sardar. M.

- Dr. A. Ghafoor

- Shah M. Safi

- Dr.Nazir Ahmad

- Hatami

- M. Asif

- Dr. Alimuddin

- M. A. Salemi (chairman)
FAO Iivestock

MADERA

DCA

COAR

UVSA

GAF/UVSA

EVC

PRB

MDC

DACAAR

A-AID

$\mathrm{FAO} / \mathrm{TCP}$

i. Approval of the agenda

The agenda was approved without any comments.

ii. Summery and approval of the last minutes

The minutes were summarized by the chairman and DACAAR was invited during the meeting to explain their veterinary activities in Laghman province. The following corrections were made:

Second Paragraph under the announcements: Mid paravets should read $B V W$; last paragraph, page 1 : GAF should read UVSA; and in the list of UVSA, PRB members should read 83 members and KBS should read KVC.

\section{iii. Announcements}

Prof. Faqir Mohammad Zemary, former dean of the veterinary faculty of Kabul University and Advisor to PRB veterinary program, has died in Peshawar (may God bless him). Fateha was offered by the participants.

FAO announced that PPR disease in different areas of East, South west and even some parts of south region has been noticed and confirmed. At present 6000 dozes of RP vaccine has beer diştributed to the VFUs in South-West. 
FAO was also trying to purchase PPR vaccine. After looking through the companies, it was found that the PPR vaccines are available, but is very expensive. Therefore, FAO ordered 500,000 doses of RP vaccines for the near future.

MADERA for the first time in their vaccine production laboratory made some mineral bricks from bone ash, salt and white cement for animals to lick. They said that the total cost for the production of one brick $(3,5 \mathrm{~kg})$ would cost them Rs.48. It has been noticed that these bricks were enjoyed by animals keenly. MADERA also plans to make some 2000 bricks for the year 1998 to be sold through their clinics following privatization policy.

FAO suggested that it would be better if MADERA could provide a Machine available in the market to increase their production. They were also suggested if samples of these bricks are distributed to their clinics for farmers awareness all over the country.

FAO announced that they ordered pasteurellosis vaccine for sheep. FAO will try to provide and make it possible for distribution during next spring.

FAO also apologized for not being able to announce the result of the cost recovery in north region for certain vaccines as previously planned. This was because of fighting in the north.

PRB announced the reaching of vaccine to Takhar by DCA and also requested FAO for providing them sheep pox vaccine and some anthelminthic and antibiotics. Regarding transportation of these medicines and vaccine ICRC could help if requested on time.

GAF announced another Piham veterinary training courses for three weeks in Nangarhar, Khost and Kandahar provinces for 42 people including trainees introduced by FAO, NGO monitors and other agencies. FAO suggested that other concerned FAO staff are also included.

UVSA announced since August 1997 about 75\% of the instruments and medicine kits has been reached and will be ready for distribution through UVSA by the end of December 1997. UVSA would also like to buy necessary Drenchers for clinics, from Pakistani companies making instrument with 3 years guarantee.

\section{DACAAR Presentation on Involving Veterináry activities}

Since one year DACAAR intended to have engineering and agriculture programs in Laghman province aiming the sustainability and increasing crops, moister conservation etc. DACAAR has two pilot projects in Chazin and Alingar district of Laghman. 
DACAAR has some range management program and would like,to assist animal husbandry and veterinary services. Therefore, they contacted GAF and MADERA in Laghman to train BVWs from the residents of the both areas to become basic veterinary works. DACAAR has already coordination with other NGOs and asked MADERA and GAF for help in their area of activities to train BVWs. The technical work and monitoring of these BVWs will be done by the concerned agencies. DACAAR will only help the construction of the clinic and other possible needs. clinic construction at village level was questioned by members whether it is necessary.

EVC agreed with MADERA to organize one month BVW training course. Some 15 persons from Laghman and 5 persons from Kunar to be trained. The course will began on 28 December 1997. They can accommodate DACAAR BVWs in the same course.

EVC has collected details on HSV vaccine reaction. Copy is attached for further information.

DCA's vaccine distribution list to FAO for the month of November 1997 is attached.

iv. General Update

Reported under Announcements.

v. Any other business.

Next Veterinary Sub-committee meeting will be held on Monday 29 December 1997 at 9:00 am.

Minutes: Faqir Mohammad 
VETERINARY SUB-COMMITTEE MEETING

Monday 29 December 1997

i. Approval of the agenda

"Planning for 1998" was put off for the next meeting due to time limitations.

ii. Minutes of the last meeting (summary and approval)

The following corrections were made to the last minutes:

- The "6000 doses", in the last paragraph of first page, should read "60,000 doses"; and

the last sentence of the 8 th paragraph, second page, should read: "From Pakistani companies making instruments with 3 year guarantee, UVSA would also like to buy necessary Drenchers for clinics".

\section{iii. Announcements}

DCA announced that their third paravet training course in Kabul was completed. The next course will start on 8 February 1998, and agencies are requested to send their nominees before 3 and 4 February to the course center in Kabul.

FAO said that they will introduce a number of trainees for DCA's next course only from Badakhshan and Bamyan. It was clarified that DCA will only cover accommodation of the trainees during the course, and is not responsible for transportation cost of the trainees; such expenses will be covered by the nominating agencies.

Commenting on DCA's announcement, FAO added that people should be trained from districts with no paravets. Sometimes, agencies introduce people without taking the responsibility of employing them 2 after the course and sending them to the respective districts. It happens that agencies with no veterinary activities nominate trainees, just for the sake of incentives.

Following a long discussion on this issue, the participants suggested to DCA to:

Develop some new criteria for participation in their
paravet training course; this should ensure that the
trainees:
are coming from districts where paravets are
needed; and
will be employed by the agencies who introduce them


for the training after completion of the course. This will not be duplication of the existing activities.

- Exercise their definite authority for rejecting nominees if not meeting the required criteria.

FAO announced that UNDP's PEACE Initiative, covering 23 districts of Afghanistan, was blocked by war in the north. Based on the decision that alternative districts be selected where work can be started, four districts (Bamyan, Panjaw, Yakawlang and Waras) of Bamyan have been recently included in the PEACE Initiative. To this end, all the five UNDP partner UN agencies, including FAO, will start their activities in Bamyan shortly. FAO's new activities in Bamyan will include supporting livestock production. FAO has started hiring local professional people livestock production specialists from the said districts are invited to send their CVs to FAO.

DCA announced that the VFU in Beho6sud 1, have been abandoned. It used to be supported by DCA before it was given to SCO. MADERA said that for 1998 they plan to start full scale veterinary programmes in that area, which will also include supporting the clinic.

\section{iv. General update}

\section{a) Security:}

It was reported by $\mathrm{PRB}$ and ICRC that access to Kapisa and Parwan have become worse. While the road via khair khana is closed, the situation in Tagab, the second road to the provinces, is also not clear.

FAO reported that the situation is still critical in Mazar. A high level UN delegation led by Mr Witsch Cestari was lately planned to travel to Mazar, but it was later canceled. FAO added that their office activities in Mazar are still in halt because their offices and vehicles have been totally looted. However, the district based clinics are functioning. Luckily they had been supplied enough vaccine just before the war.

ICRC said that, using ICRC's country-wide radio facilities, they will try to provide ACBAR with updated security information, specially about the north, which can then be disseminated by ACBAR to other agencies.

\section{b) Activities:}

ICRC reported that in the process of rehabilitating vaccine production in Kabul, they have partly rehabilitated the Badambagh agriculture premises. This building was allocated by the Agriculture Ministry for this purpose. 
ICRC suggested that the member agencies should report on quarterly basis to the sub-committee about the various disease rates recorded in their clinics. This will help a more proper and need-friendly planning of activities.

However, various agencies in the floor disagreed with this suggestion showing concerns over its practicality. FAO said that they had already started such a process within their supported clinics, but it took more than a year for the information to be obtained and consolidated, and even then it was not much useful.

MADERA's vaccine production laboratory in Jalalabad will be in the position to produce all kinds of vaccine, excluding Sheeppox and NDV, in 1998. As for CCPP, MADERA will still continue production of auto vaccine.

GAF reported that following their PIHAM training courses for male inside Afghanistan, they have recently completed a similar course for female in Peshawar. About 12 women from

Kabul, Nangarhar, Parwan and Herat participated in this course. Such programmes will be expanded in the future. GAF added that the PIHAM work by female is practically done in 3 districts of Kabul as well as one district in Nangarhar. The Taliban have not restricted this activity.

Reporting on the membership status of UVSA, GAF said that there are now 369 member veterinarians. CoAR has also joined the association recently. It was added that according to UVSA's policy in case of a member's death, the association will pay $\$ 500$ for the funeral as well as $\$ 100$ per each family member to the deceased's family.

COAR has started an ecto-parasite spray campaign in some districts of Logar, Wardak and Ghanni. So far around 335 stables for more than 3553 animals have been sprayed. Tricholorphane has been used as the spray chemical.

\section{v. Annual review of the Veterinary Sub-committee}

ACBAR circulated copies of "A review on the Veterinary subcommittee in 1997" to the participants. Using the handout, ACBAR briefly reported on the highlights of sub-committee's meetings during 1997. The shortcomings and unaccomplished activities were specially focused on and suggested to be considered for the next year. Copy is attached for those who have not received it.

vi. Any other business 
ICRC requested FAO to train some of ICRC's staff on PIHAM. FAO, in response, said that this programme has so far been very limited in span. However, FAO intends to expand it, and ICRC will also be included in the future plans.

ICRC also requested ACBAR to consider involving ICRC in the training activities of CPAU network. It was said that dealing with conflict is the day to day experience for ICRC and its staff. Therefore, CPAU's training programmes will be very effective.

Another point raised by ICRC was the problem of finding areas for their activities, and the fear of duplicating. ICRC requested ACBAR and FAO for information on the already existing district based clinics, and the guidelines for agencies to support the clinics. ICRC was told that according to policy, one VFU per district should be supported. To this end, ICRC may move to districts with no VFU and/or take over VFUs from those agencies unable to run them properly.

The chairman, Dr Salemi, said that this was the last meeting of 1997 and election of new chairman and deputy chairman for the sub-committee would take place in the next meeting, so he wanted to thank the members for their confidence in him and cooperation during the past year.

THE NEXT VETERINARY SUB-COMMITTEE MEETING will take place at 9:00 am on Monday 26 January 1998 in ACBAR office.

Chairman : Dr Salemi, FAO/TCP

Minutes : Fagir Mohammad, ACBAR

The participants:

- Dr Rashidi

Dr Samsoor

- Dr Samsoor

Veterinarian

Veterinarian

ICRC

Ext Coordinator

Vet Coordinator

DCA

Dr A Ghafoor " Director

Dr Shah M Safi Coordinator

COAR

Dr Mehraban

National Manger

GAF/UVSA

EVC

Eng Esmatullah Planning Director

FAO Livestock

Dr M Zia

Monitor

Dr M S Tahir

Livestock Coord.

Dr M A:Salemi

A Hatami

Coordinator

A Jawed Ludin

Veterinarian

ADA

PRB

MADERA

FAO/TCP

MDC .

Faqir Mohammad Programme Officer

ACBAR

ACBAR 


\section{STRATEGY FOR COST RECOVERY ON VAC.CINES}

April 1997

Food and Agricultural Organization of the United Nations

United Nations Development Programme

T.J. Barker

Programme Manager 


\section{A. GENERAL BACKGROLND}

\section{Context}

1.1 In $1996 \mathrm{FAO}$, under its Technical Cooperation Programe, undertook a lengthy study of agricultural conditions in Afghanistan which resulted in the publication of a paper entitled "Afghanistan Agricultural Strategy". This attempt to look at long tem agricultural strategy: identified the goal of food security as the most important development objective on the road to reliabilitation It further broke this goal down into three immediate objectives. protect lives through food aid, re-establish agricultural output and increase agricultural output. These would then lead into the next goal economic and social development. Self-sustainability developed at an early stage will underpin the success of this strategy and will also appeal to the well developed entrepreneurial instincts of Afghans

\section{Description of Sub-sector - The Significance of Livestock Production}

2.1 Livestock production has always been an integral part of smallholder farming systems in Afghanistan, providing farm power, income, supplementary food, wool and leathor Irivestock have also provided a means of transforming crop residues and grazing into marketable commodities, and have contributed to the maintenance of soil fertility. There is a body of solid evidence to show that there is a positive correlation between the livestock component of a small farm enterprise and food crop yields and net returns from farming On nany small farms livesiock: may supply the only source of cash income to the household

2.2 Before the war, livestock products were estimated to comprise $18 \%$ of the country's domestic producr. While the majority of small stock, and more or less all calle were onmed ty sedentary communities, some $27 \%$ of the national flock belonged lo nomadic and seminomadic pastoralists who also owned camels. Horses and donkeys were particularly important for transport. In the rorth, horses were also a major status symbol. The prewar national herd was estimated at 485 million cattle, 26.8 nillion small ruminarits, 0.3 million camels and 1.74 million horses and donkeys and mules. Draft and pack animals were, and still are important although in some areas there has been recent trend towards mechanisation of cultivation due to a shortage of oxer. In 1995 the FAOANDP Animal Health and Livestock Production Programme (the Programme) completed a ground census in $169(52 \%)$ of the districts in Alghanistan. Totals were 2.1 million cattle and buffaloes (the vast majority being cattle), 18.9 sheep and goats and 6.7 million poultry.

2.3 Most famers in Afghanistan understand that there is a complex of factors wim govern the productivity of their livestock. These factors inchude anmal health and disease control. management, nutrition and breeding: all of which are varyingly important. In a relief and rehabilitation progranme, it thus makes sense to initially emphasise animal health and disease control aspects, in part because these aspects also lend themselves to the creation of locally self. sustaining services by introducing the concept of the "user-pay's"

24 There is a considerable body of information on the most common livestock 
tratments provided by the district dinics in Afghanistan and gamered from the clinical records These records frovide information on suspected causes and regional and seasonal occurrence seen in the clinics. Such diseases as gastrointestinal diseases gencially due to internal parasites poor quality feed, erratic feeding practices and weight loss due to seasonal deficience of yolality feeds. reproductive disorders, respiratory diseases and internal parasites are common problems. The project diseases investigation section also reviews the work of project supported laboratories which provide sonc reports on infectious diseases from samples sent in by district clinics. All this information forms the basis for decisions on priority vaccines and medicines and on the extension programmes. It has been found so far that the most important diseases affecting ruminants are thought to be anthrax, enterotoxaemia, sheep pox, contagious caprine pleuropneumonia (CCPP), blackquarter, foot and mouth disease and haemorhagic septicaemia. Newcastle and gamboro diseases constitute major threats to poultry production.

\section{A Review of the History of Cost Recovery}

3.1 The financing of aid progranmes in Afghanistan has in recent years taken the form of provision of emergency funds for demining, the provision of emergency food to war torn areas. the retum of refugees and creation of income generating projects for the returnees and widows More recently there has been some movement towards rehabilitation projects in order to bring about food security and a concomitant reduction in cmergency foods imports. At this juncure development was not generally considered by donors.

32 The strategy for the distribution of emergency aid squezed out all development work which, although there may be some easing of this at the present time, has resulted in a shothge of funds for veterinary service expansion, livestock development work and other development orientated activities. In turn this has forced the veterinary services to become nore and more self-sustaining, the best example being the delivery of medicines to famers which moved from being free at the point of delivery, through a phase of progressively reducing subsidies to full cost recovery which was attained at the beginning of 1994 . Although there was resistance to the idea of this policy most Afghans involved in Veterinary Services agreed that this move was essential and in the event the strategy proved to be correct in that farmers paid. In fact farmers had always paid veterinarians, even when medicines were free, in order to gain priorily of for many other reasons. Famners were much more used to pajing thet the detractors from the user-pays' policy would admit.

33 Full cost recovery on medicines gave veterinanans the freedom to organise theit own supplies and, although this did not suit many of them, there were some that bonefited directl: and many others who benefited through the formation of small purchasing groups. Veverthcless. there were still problems with the supply of good quality medicines and to overcome these a country wide Veterinary Scrvices Association was formed in mid 1996 by the veterinarians themselves in arder to pool resources so as to provide the opportunity to purchase better quality medicines at cheaper prices

3.4 Mean while all vaccines purchased by the progranume have been and are still being provided fiee except that veterinarians charge a service fee to farmers. In addition the funds 
provided only purchased sufficient vaccines to cover the most important diseases athd even then there is insufficient for every animal in the country. There are other diseases for which farmers request vaccine cover but it is not possible to supply all such needs with the limited funds available. Moreover, Newcastle disease vaccine for chickens, which is distributed by the programme is never sufficient to cover all hens and most private pharmacies in Afghanistan stock Pakistan manufactured vaccines at full cost price. There is therefore already an element of cost recovery for some vaccines in Afghanistan.

3.5 In reccnt years supplies of vaccines, provided through donor funding. have been intermittent and generally first orders after funds have been released have arrived too late for the spring season vaccination campaigns. Major funding was received in 1995 and in 1997 . Very little money was ayalable in 1996 which underscored the intermittent nature of vaccine supplies.

\section{Country Strategy}

4.1 Currently the unification of the govemment of the country has not yet been achieved and in parts of the country war continues. Nevertheless the warring factions are generally confined to small areas of Afighanistan at any one time: and access to rural communities is possible and is achieved to a very large extent

4.2 Programme policy is to spread clinical and preventative veterinary health care as widely as possible. In order to do this NGOs were recnited to help manage an ever increasing number of district based Veterinary Field Lnits (VFUs). The FAO Programme has developed a system of 5 Regional Oftices which monitored both the NGOS and the VFLs activities These Regional Offices also act as storage and supply centres, particularly for vaccines, where cold chain ficilities (fteezers and generators) were located. The Head Office or the Programme is currently based in Isiamabad, Pakistan, primarily for ease of banking and communications which are not available inside Afghanistan. The Islamabad Office is also responsible for organising the receipt of imported vaccines, for clearing them through customs and for their distribution through the Regional Offices to the NGOs and the VT:Ls

4.3 It is also understood that the new unified government of Afylianistan. when it comes, will be unable for some years to come, to support the public sood aspect of veterinary services which are normally a government responsibility. The Programme therefore accepts that cven 'public good' activities will have to be financed or in some way undertaken by the VFL' sector. Thus cost recovery on all aspects of veterinary services are the constant aim and are contimually under review by the Programme.

4.4 In the meantime the FAO Programme has undertaken the development of an extension programme, using participatory methods: the Animal Health and Production Improvement Modul:Afghanistan that is known as PLHAM (meaning continuous). The procedures being put in place are to teach the VFL veterinarians how to use the participatory methods which also afford them the chance to better understand the villagers points of viex: This system facilitates discussion amongst farmers for the improvement of livestock health and production and is a vehicle through which such ideas as cost recovery and self-sustainability can 
be discussed. Its main aim is to make farmers more proactive in animal management and it also provides a fomm to review and teach such things as the needs for proplylactic treatments.

\section{Institutions}

51 As is stated above there is no urified government and as a by-product of this there are no recognised government structures Such structures that do remain are under-funded to such an extent that in many areas they do not exist any longer and the civil servants have long since departed and taken up other pursuits. Furthermore, these structures are unlikely to emerge for some time to come as funding will take time to acquire and structures and personnel will take time 10 build and train.

5.2 Even when government institutions do start to emerge they will not be able to Frovide money to subsidise veterinaty' services and it will be many years before they can. In the meantime veterinary services and vaccinations of anirnals against important diseases must continue. Fu: themore, the nature of the government structures are likely' to be changed in the light of modern developments which means that past ideas, strategies and procedures are unlikely to be revived, and self-sustainability of institutions, such as veterinary serrices, is likely to be the norm.

\section{The Case for Cost Recovery on Vaccines}

6.1 Food security is the first main goal as discussed above. The paramount need of animal power for ploughing and transport and the Afghan preference for meat and livestock products for food means that the maintenance of the health of farm aninuals is of major importance.

62 In any health care system it is fundamentally recognised that prevention is better and cheaper than cure. Prophylaxis in the form of vaccinations must theretore be considered. In addition the prevention of the spread of diseases is not just a matter for Afghanistan itself but it is also of sorne concern to nejghbouring countries who fear that such a war torn country may not have proper preventative measures in place and it could act as a reservoir for the spread of diseases regionally. Thus even if the whole country cannot be supplied with sufficient vaccine at least internal bands of vaccinated animals will prevent the spread of epizoolic diseases within and across borders.

63 From the point of view of the farmer the economic effects of disease is the main point of interest and in this respect some diseases are well known to them and they therefore also know the inportance of vaccination against these diseases. Anthrax and enterotoxaemia fall inte this category and for these they are always ready to pay because they recognise both the diseases and the poteritial losses. Otherwise it is difficult to convince a farmer to spend money on otherwise healthy aninals.

64 Rinderpest on the other hand is not wide spread but it is the most devastating disease of all in terms of mortality. It is not endemic in the county and it is generally imported 


\section{The Strategy for Cost Recovery on Vaccines}

from neighbours Recently it Page 6

1 vaccination seens to have prevented the spread as an emergency in the south where ring emergency rules and this may also be the cased. In this case vaccine was supplied under becomes involved with regional eradication campagn future, particularly when Afehanistan

6.5 Other diseases, such as sheep pox and blackquarter, have less apparen economic
losses and are more difficul to establish as cost recovery vehicles. For and (FMD) is known to be important because it as cost recovery velicles. Foot and mouth disease and, if this disease should strike a crituse it prevents oxen from ploughing or providing transport be affected. The problem with font and mo of year, then food crops such as wheat may also period of time, the disease generally occurs vaccine is that it covers animals for a very shon necessarily fully effective without knowing which heral diflerent strans and therefore it is not The vaccine also requires an efficient and widely strains are currently circulating the couritr: Although much is being done to set up a cold chly established cold chain up to the poin of use FMI is too expensive and these vaccines chain it is not yet efficienc enough for FMD Thus

6. pharmacies is accepted on an ad hoc basis.

disease, gamboro disease and fow poxe main diseases that affect farm production viveastle essential, all farmers know this and Regular prophylactic adninistration of the first two is problem is that locally manufactured vaccing training courses stress the need for vaccination. The are expensive. Subsidy needs to be continues we not heat stable whilst inported ones, which are, capacity to pay increases.

68 Only sonse vaccines have been purchased and supplied free of charge to the VFL In any case even these vaccines are also avalable in the markets and commercial pharmacies at funding: does not supply sufficient vaccines to cover the whole country

6.9 Linless doinors

vaccines into the future, which hurantee regular and timely suppont for the lunding of free stared the better it will be for all concerned pato do, then the socner that cost recovery is unlikely as donor funds are becoming more scarce Lantuly the farmers. Such guarantees are faster introduction of self-sustainability to proute fonderlining this is the need for more and plan ahead to introduce such systems at an early de food security and projects therefore have to of cost recovery is outlined below.

\section{The Strategy for Cost Recovery}

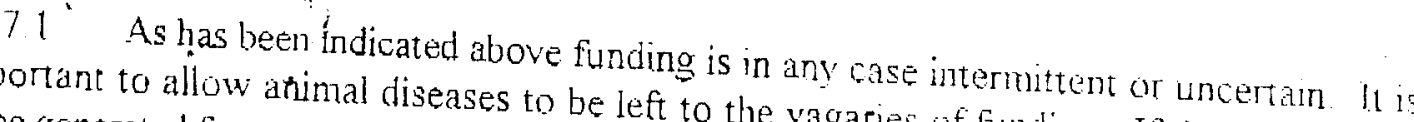
coo imporant to allow animal diseases to be left to the vagaries of funding If therefore funds sources. The only source of funds inces then de facto they have to be generated from internal File: licas 


\section{The Strategy for Cost Recovery on Vaccines}

responsibility to keep his animals alive and heage.7

food security.

7.2 It has been indicated above that some cost recovery already takes place. This has base should be buitup wo bout a change of attitude in all farmers and at the same time a capital of vaccines to help all farmers for such an the self-sustainable purchase of a wider rance already been put in place through their veterinary Scrvices Association own infrastructure has
below.

7.3 Therefore, the main

possible. However, the implementation of must be to attain full cost recovery as soon as that of medicines because the perceptions of the process for vaccines will be very different from not generally sick before the administration of farmers towards these are different ... animals are ton quickly then good preventive veterinary care will be If high prices for vaccines are instituted animal production and food security. Therefore aill be significantly reduced to the detriment of

cautious approach is advocated

as bing top slow, cost recoven she start of cost recovery (see Table I below) may be regarded in order to acclimatise al sections of start at a very low level and increase slowly to begin with Improvement Module (PTHAM) needs time to the Programme Animal Health and Production

mature or, and the recent reductions in, fo the idea of cost recovery in spite of the intermittent cost recovery easier to accept. it would, funding. A slower inplementation process would make in a unified policy in Afghanistan. On this basis a system and it would encourage all agencies to join period may be acceptable.

7.6 Liperience indicites

strategies is generally faster than planed speed of implementation of such cost recovery. because of swifter acceptance by famers than the plannenstantly changing circumstances and Iable 1 is expected to be significantly brought forwanters expect. The end point indicated in annual review and to changes as a consequence of surd. Any strategy should be subject to an particularly the speed. of bringing about full cost reco review. Changes in the direction, and such revieus

introduction of cost recovery $\mathrm{NGOS}$, who manage the VFL's in the field are wary of the in the north, where none of the itidesenche They therefore agree to a tost period to be carried out introducing the nest phase.

7.8 It is therefore proposed year plan as shown in Table 1 below (which is lithely for cost recovery should be based on a six. File: Th: 


\section{The Strategy for Cost Recovery on Vaccines}

purchased by the programme are indicated with the percentage recovery that rises from year to year. Locally manufactured (Pakistan) Newcastle disease vaccine is very dependent on cold chain facilities which is being built up, but meanwhile the imported, heat stable vaccines are currenty very costly and are too expensive for lanners. Therefore cost recuvery is planned for a later start

7.9 In addition, sometimes Fowl pox, gamboro disease and haemorhagic septicamia vaccules have been purchased by the programme in the past. These will also be sibject to a cost recovery regime similar to sheep pox and black quarter as shown in the table

7.10 Other vaccines not merntioned and not purchased by the progranme are in any case on full cost recovery if the farmers wish to request veterinarians to purchase them. with the exception of rinderpest vaccine. For the time being this will be regarded as 'public good' and will be fully subsidised

7.11 Rabies vaccine will be reviewed as the needs arise. A vaccination campaign covering most of the country has been completcd and most dog owners paid for this service. The vaccine confers immunity for three years and by the time re-vaccination bccomes necessary some level of cost recovery' will be imposed.

Table 1. Percentage Cost Recovery of Vaccines by Yiar.

\begin{tabular}{|l|l|l|l|l|l|l|}
\hline 1 & & & \\
\hline
\end{tabular}

7.12 Moneys collected from the sale of vaccines to vers (and farmers) will be accumulated in a separate bank account operated by the VSA and it will be used exclusively to purchase vaccines as agreed by the members. Supervision and management of the bank account 
will be cartied out by the Senior Manager of the VSA together with a committce made up of VSA staff, FAO and an appropriate member from an NGO operating in the veterinary field, similar to the FAO food for seed project where money is managed by just such a committee.

\section{Veterinary Services Association}

8.1 The VSA was started up to support veterinarians in the supply of good quality medicines which. since full cost recovery was introduced for medicines in 1994, they have had difficulty in obtaining on a regular basis. To a large extent they have had to rely on products manufactured in Pakistan which were often of questionable quality. In order to purchase supplies trom further afield then there had to be a more cooperative effort with pooled resources,
particularly money.

82 The veterinarians themselves, with the support of the FAO Programme and most of the NGOs set up a system to pool money for the purchase of medicines. Six regional VSAs were started by the drawing up of articles of association and by the election of officers fiom amongst their own numbers. Each association was to be non-profit naking but they would take sufficient monies from the sale of medicines to cover their costs, generally set in the early stages at $5 \%$ of cost.

8.3 Six Associations still presented a relatively cumbersome structure and in any case 5ome kinit of central ordering operation needed to be provided. Therefore an Limbrella VSA was stanted whll two permanent staff and based in Peshawar. The person appointed to head of LVSA was, and is, experienced in the ordering of medicines as he held such a position in the old Fertilizer Company of Afghanistan which was responsible for this task in former times.

8.4 The first orders, placed in December 1996, proved to be highly successful in terms of quality and price and it put the veterinarians on a very much better compctitive base. They further had the dramatic effect of reducing the price of medicines in the private pharmacies and in the markers because of the new competition.

8.5 Since the LVSA and VSAs are owned by the vets and since it is in their interests to be relatively efficient, it is believed that they would be the best inclependent vehicle to provide a potential vaccine purchasing service in the future. Furthermore, if these operations are superised by committee of interssted parties (FAO. NGOs, Vets, etc), then it is believed that the needs of accountability and transparency will be served

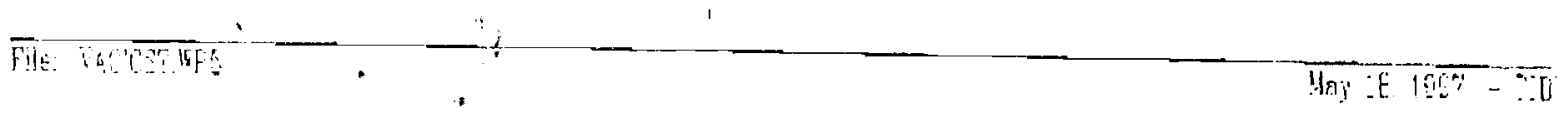




\section{Proposed Vaccines Cost Recovery Strategy}

\begin{tabular}{|l|l|l|l|l|l|l|}
\hline $\begin{array}{l}\text { Year/ Type of } \\
\text { Vaccine }\end{array}$ & $\begin{array}{l}\text { ASV } \\
\%\end{array}$ & $\begin{array}{l}\text { ETV } \\
\%\end{array}$ & $\begin{array}{l}\text { NDV } \\
\%\end{array}$ & $\begin{array}{l}\text { SPV } \\
\%\end{array}$ & $\begin{array}{l}\text { BQV } \\
\%\end{array}$ & Comments. \\
\hline 1997 & 10 & 10 & & & & Just in the North and North West \\
\hline 1998 & 1015 & 1815 & & & & In all Regions \\
\hline 1999 & 20 & 20 & 20 & 20 & 20 & In all Regions \\
\hline 2000 & 50 & 50 & 50 & 50 & 50 & In all Regions \\
\hline 2001 & 75 & 75 & 75 & 75 & 75 & In all Regions \\
\hline 2002 & 100 & 100 & 100 & 100 & 100 & In all Regions \\
\hline
\end{tabular}

Emergency vaccination like rinderpest would be $100 \%$ subsidized, but vaccination fee would be always allowed. 


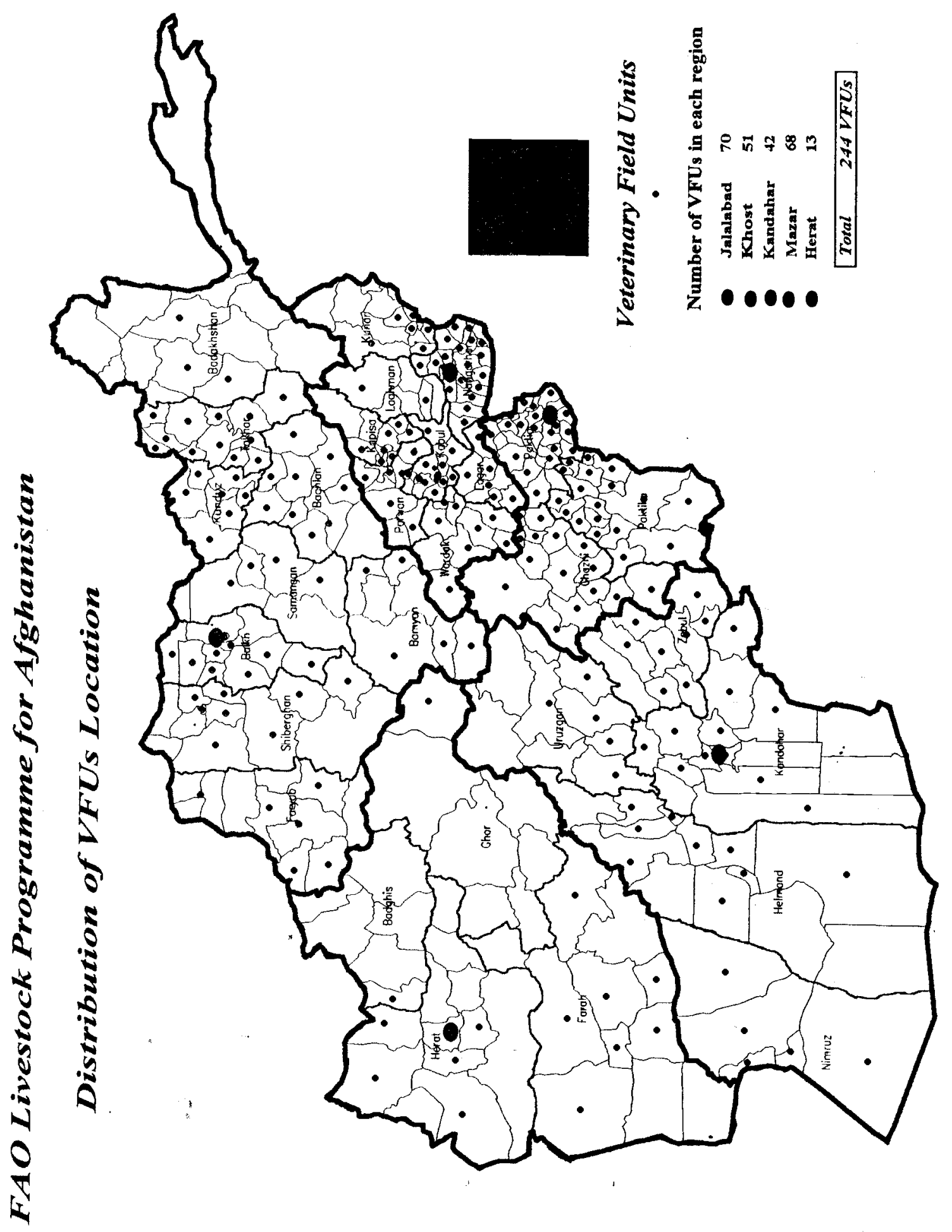




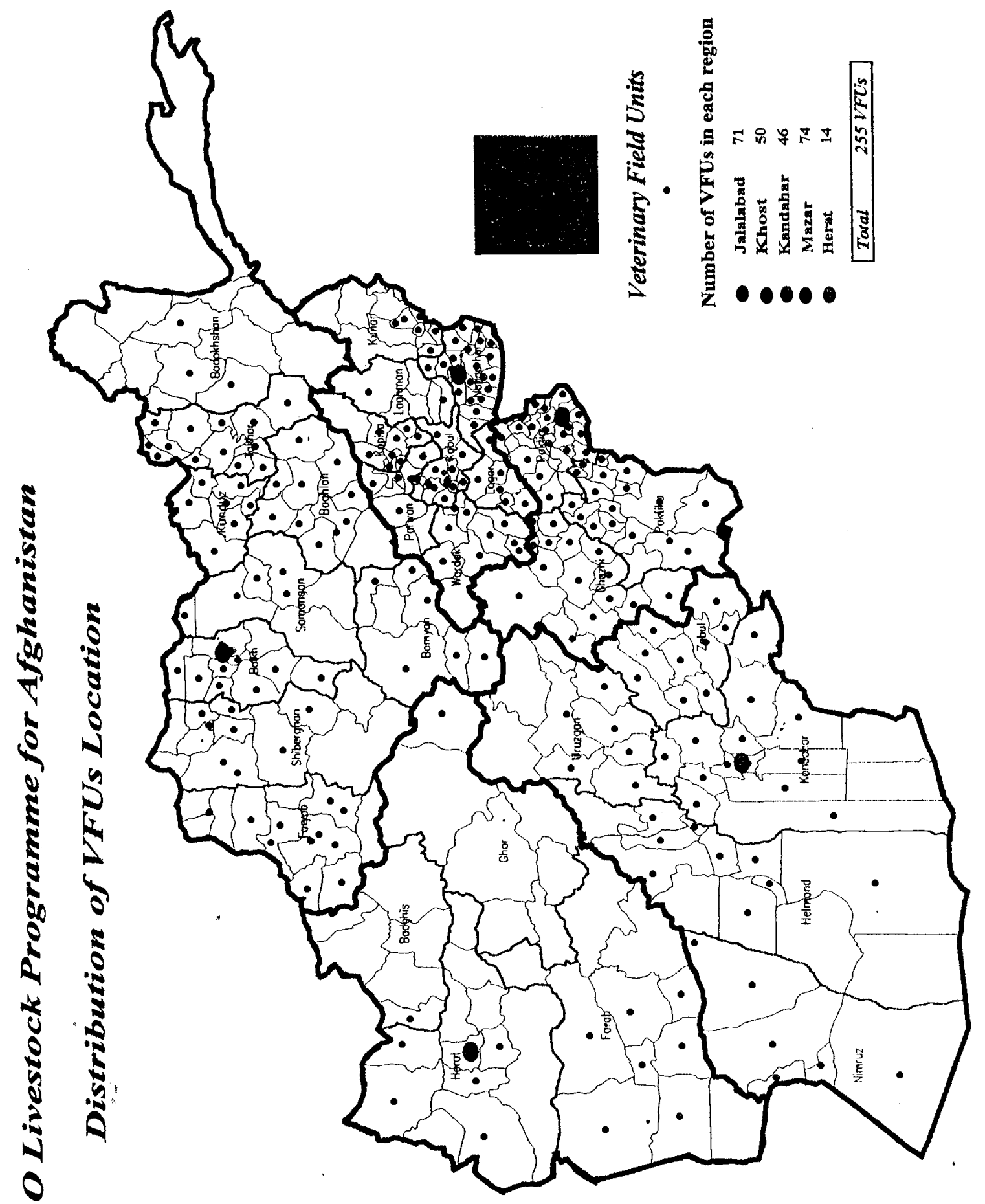




\begin{tabular}{l|l|l|l|}
\multicolumn{1}{c}{ Province } & \multicolumn{1}{c}{ District } & \multicolumn{1}{c}{ IP } & Rgn \\
\hline Qandahar & Arghandab & ADA & QR \\
\hline Zabul & Arghandab & ADA & QR \\
\hline Zabul & Atghar & ADA & QR \\
\hline Wardak & Chak-e-Wardak & ADA & JB \\
\hline Uruzgan & Chowreh & ADA & QR \\
\hline Zabul & Dai Chopan & ADA & QR \\
\hline Qandahar & Dand & ADA & QR \\
\hline Uruzgan & Dehrawod & ADA & QR \\
\hline Wardak & Dimirdad & ADA & JB \\
\hline Uruzgan & Gizab & ADA & QR \\
\hline Wardak & Jaghatu & ADA & JB \\
\hline Wardak & Jalraiz & ADA & JB \\
\hline Uruzgan & Khasuruzgan & ADA & QR \\
\hline Wardak & Maidanshar & ADA & JB \\
\hline Qandahar & Maruf & ADA & QR \\
\hline Zabul & Mizan & ADA & QR \\
\hline Qandahar & Nesh & ADA & QR \\
\hline Wardak & Nirkh & ADA & JB \\
\hline Zabul & Qalat & ADA & QR \\
\hline Wardak & Sayedabad & ADA & JB \\
\hline Zabul & Shah Jui & ADA & QR \\
\hline Qandahar & Shega & ADA & QR \\
\hline Zabul & Shinkai & ADA & QR \\
\hline Zabul & Shmalzai & ADA & QR \\
\hline Uruzgan & Tarin Kot & ADA & QR \\
\hline
\end{tabular}

\begin{tabular}{|c|c|c|c|}
\hline Jowzjan & Fandkhoy & PALR & $\mathrm{M} \mathrm{MZ}$ \\
\hline Jowzjan & Aqcha & ALR & $\mid M Z$ \\
\hline Samangan & Aybak & ALR & |MZ \\
\hline Balkh & Balkh & ALR & $\mathrm{MZ}$ \\
\hline Balkh & Charbolak & ALR & $1 \mathrm{MZ}$ \\
\hline Balkh & Chemtal & ALR & $\mathrm{MZ}$ \\
\hline Balkh & Dawlatabad & ALR & TMZ \\
\hline Balkh & Dehdadi & ALR & $M Z$ \\
\hline Jowzjan & Faizabad & ALR & $M Z$ \\
\hline Samangan & Hazrat Sultan & ALR & $\mid M Z$ \\
\hline Samangan & Kaldar & ALR & $M Z$ \\
\hline Balkh & Keshendeh & ALR & $M Z$ \\
\hline Jowzjan & Khanaqa & ALR & $\mathrm{MZ}$ \\
\hline Jowzjan & Khojaduku & ALR & $\mathrm{MZ}$ \\
\hline Samangan & Khulm & ALR & MZZ \\
\hline Samangan & Khuram S. & ALR & MIZ \\
\hline Balkh & Mazar & ALR & $\mid N Z$ \\
\hline Jowzjan & Mordian & ALR & $\mid M Z$ \\
\hline Balkh & Nahrishahi & ALR & $\mathrm{MZ}$ \\
\hline Jowzjan & JSangcharak & ALR & $\mathrm{MLZ}$ \\
\hline Sari Pul & Saripul & ALR & $M Z$ \\
\hline Jowzjan & Shiberghan & ALR & $M Z$ \\
\hline Balkh & Sholgara & ALR & $\mathrm{MZ}$ \\
\hline Balkh & Shortepa & ALR & $\mathrm{MZ}$ \\
\hline
\end{tabular}

\begin{tabular}{|l|l|l|l|}
\hline Baghlan & Andrab & AOR & $\mathrm{MZ}$ \\
\hline Baghlan & Baghlan & AOR & $\mathrm{MZ}$ \\
\hline Baghlan & Burka & AOR & $\mathrm{MZ}$ \\
\hline Bamyan & Center & AOR & MZ \\
\hline Baghlan & Dhani-e-Ghori & AOR & $\mathrm{MZ}$ \\
\hline Baghlan & Dushi & AOR & MZ \\
\hline Bamyan & Kahmard & AOR & MZ \\
\hline Baghlan & Kayon & AOR & MZ \\
\hline Baghlan & Khinjan & AOR & MZ \\
\hline Baghlan & Khost-wa-fering & AOR & MZ \\
\hline
\end{tabular}




\begin{tabular}{|c|c|c|c|}
\hline Province & District & IP & Rgn \\
\hline Baghlan & INahrin & PAOR & JMZ \\
\hline Baghlan & Pullkhumrl & AOR & IMZ \\
\hline Bamyan & Shibar & AOR & IMZ \\
\hline
\end{tabular}

\begin{tabular}{|l|l|l|l|}
\hline Farah & Anardara & BCC & $H T$ \\
\hline Farah & Bakwa & BCC & HT \\
\hline Farah & Balabuluk & BCC & $H T$ \\
\hline Farah & Center & BCC & HT \\
\hline Herat & Center & BCC & HT \\
\hline Herat & Ghorian & BCC & HT \\
\hline Herat & Gulran & BCC & HT \\
\hline Herat & Guzra & BCC & HT \\
\hline Farah & Rhak e Safid & BCC & HT \\
\hline Herat & Kush-i-Robat Sangi & BCC & HT \\
\hline Herat & Kushk-i-Kona & BCCC & HT \\
\hline Farah & Qala-e-kah & BCC & HT \\
\hline Farah & Shindand & BCC & HT \\
\hline Herat & Kenda Jan & BCC & HT \\
\hline
\end{tabular}

\begin{tabular}{|l|l|l|l|}
\hline Nangarhar & Achin & EVC & JB \\
\hline Konar & Assadabad & EVC & JB \\
\hline Nangarhar & Batikot & EVC & JB \\
\hline Nangarhar & Behsud & EVC & JB \\
\hline Nangarhar & Darae Noor & EVC & JB \\
\hline Nangarhar & Shanikhel(shinwar) & EVC & JB \\
\hline Nangarhar & Gowshtah & EVC & JB \\
\hline Nangarhar & Kama & EVC & JB \\
\hline Laghman & Katz Aziz Khan & EVC & JB \\
\hline Konar & Khas Konar & EVC & JB \\
\hline Nangarhar & Kouz Konar & EVC & JB \\
\hline Nangarhar & Lalpur & EVC & JB \\
\hline Konar & Nazar(Nurgal) & EVC & JB \\
\hline Konar & Narang & EVC & JB \\
\hline Nangarhar & Nazian & EVC & JB \\
\hline Laghman & Nooristan & EVC & JB \\
\hline Nangarhar & Rodat & EVC & JB \\
\hline Nangarhar & Rodat(Kot) & EVC & JB \\
\hline Konar & Sarkani & EVC & JB \\
\hline Nangarhar & Surkhrud & EVC & JB \\
\hline Konar & Watapur & EVC & JB \\
\hline
\end{tabular}

\begin{tabular}{|l|l|l|l|}
\hline Faryab & Shirin Tagab & FVC & MZ \\
\hline Faryab & Almar & FVC & $M Z$ \\
\hline Faryab & Belchragh & FVC & MZ \\
\hline Faryab & Dawlatabad & FVC & MZ \\
\hline Faryab & Gurziwan & FVC & $M Z$ \\
\hline Faryab & mam Sahib & FVC & $M Z$ \\
\hline Faryab & Khwaja Mussa & FVC & $M Z$ \\
\hline Faryab & Khwaja Subzposh & FVC & $M Z$ \\
\hline Faryab & Maimana & FVC & $M Z$ \\
\hline Faryab & Qeysar & FVC & MZ \\
\hline
\end{tabular}

\begin{tabular}{|l|l|l|l|}
\hline Ghazni & Ab-Band & GAF & KS \\
\hline Ghazni & Andar & GAF & KS \\
\hline Logar & Azra & GAF & JB \\
\hline Kabul & Bagrami & GAF & JB \\
\hline Paktia $:$ & Bak & GAF & KS \\
\hline Logar & Baraki Barak & GAF & JB \\
\hline Ghazni & Center : & GAF & KS \\
\hline Paktia & Chamkani & GAF & RS \\
\hline Nangarhar & Chaparhar & GAF & JB \\
\hline
\end{tabular}


Province District IP Rgn

\begin{tabular}{|c|c|c|c|}
\hline Rabul & TChar Asiab & GAF & $\mathrm{JB}$ \\
\hline Kabul & Char Dehi & GAF & JB \\
\hline Logar & Charkh & GAF & JB \\
\hline Paktia & Dand-wa-patan & GAF & KSS \\
\hline Kabul & Deh Sabz & GAF & JB \\
\hline Nangarhar & Dehbalah & GAF & JB \\
\hline Ghazni & Dehyak & GAF & KS \\
\hline Ghazni & Gilan & GAF & RS \\
\hline Ghazni & Giru & GAF & KS \\
\hline Pakfia & Gorbaz & GAF & KS \\
\hline Nangarhar & Hesarak & GAF & JJB \\
\hline Paktia & Ismailkhel & GAF & KS \\
\hline Ghazni & Jaghatu & GAF & KSS \\
\hline Paktia & Jaj! & GAF & KSS \\
\hline Paktia & Jaji-Maidan & GAF & KKS \\
\hline Nangarhar & Jalalabad & GAF & JJB \\
\hline Paktia & Jani Khil & GAF & KS \\
\hline Logar & Kharwar & JAF & JB \\
\hline Nangarhar & Khogiani & GAF & JJB \\
\hline Logar & Khoshi & GAF & JB \\
\hline Paktia & Khost & GAF & KS \\
\hline Ghazni & Khwaja Omari & GAF & RS \\
\hline Kabul & Mir Bacha Kot & GAF & JB \\
\hline Nangarhar & Mohmand Dara & GAF & $\mathrm{JB}$ \\
\hline Ghazni & Moqur & GAF & RS \\
\hline Logar & Muhammad Agha & GAF & JB \\
\hline Paktia & Musa Khil & GAF & KS \\
\hline Rabul & Musahi & GAF & JB \\
\hline Paktia & Nadir Shah Kot & GAF & KS \\
\hline Ghazni & Nawa & GAF & RS \\
\hline Nangarhar & Pachier Wa Agam & GAF & $\mathrm{JB}$ \\
\hline Kabul & Paghman & GAF & JB \\
\hline Kabul & QaraBagh & GAF & $\mathrm{JB}$ \\
\hline Ghazni & Qarabagh & GAF & RS \\
\hline Kabul & Sarobi & GAF & $\mathrm{JB}$ \\
\hline Paktia & Sayed Karam & GAF & KS \\
\hline Paktia & Sayed Khil & GAF & KS \\
\hline Nangarhar & Shairzad & GAF & JB \\
\hline Kabuॉ & Shakar Dara & GAF & JB \\
\hline Paktia & Shamal & GAF & RS \\
\hline Paktia & Sperah & GAF & KS \\
\hline Paktia & Tani & GAF & RS \\
\hline Paktia & Trazai(Alisher) & GAF & KS \\
\hline Nangàrhar & Wazir & GAF & JB \\
\hline Paktia & Yaqubi & GAF & KS \\
\hline Ghazni & Zina Khan & GAF & KS \\
\hline Paktia & Zurmat & JGAF & KS \\
\hline
\end{tabular}

\begin{tabular}{|l|l|l|l|}
\hline Kabul & Center & KVC & JB \\
\hline Parwan & Charikar & RVC & JB \\
\hline Paktia & Gardiz & KVC & KS \\
\hline Logar & Pul-e-Alam & KVC & JB \\
\hline Kabul & Qala-e-Wazir & KVC & JB \\
\hline Kabul & Wazirabad & KVC & JB \\
\hline
\end{tabular}

\begin{tabular}{|l|l|l|l|}
\hline Qandahar & Arghistan & MCl & QR \\
\hline Helmand & Bust & MCl & QR \\
\hline Qandahar & Daman & MCI & QR \\
\hline Helmand & Garmser & MCl & QR \\
\hline Qandahar & Ghorak & MCI & QR \\
\hline Helmand & Kajaki & MCl & QR \\
\hline
\end{tabular}




\begin{tabular}{l|l|l|l|}
\multicolumn{1}{c}{ Province } & \multicolumn{1}{c}{ District } & \multicolumn{1}{c}{ IP } & Rgn \\
\hline Qandahar & Khakrez & MCI & QR \\
\hline Qandahar & Maywand & MCI & QR \\
\hline Helmand & Musa Qala & MCI & QR \\
\hline Qandahar & Panjwai & MCI & QR \\
\hline Zabul & Share Safa & MCI & QR \\
\hline Qandahar & Shawalikot & MCl & QR \\
\hline Qandahar & Spin Boldak & MCI & QR \\
\hline
\end{tabular}

\begin{tabular}{|l|l|l|l|}
\hline Uruzgan & Lal-Sarjang & OXF & MZ \\
\hline Bamyan & Panjab & OXF & MZZ \\
\hline Bamyan & Waras & OXF & $M Z$ \\
\hline Bamyan & Yakawlang & OXF & $M Z$ \\
\hline
\end{tabular}

\begin{tabular}{|c|c|c|c|}
\hline Kapisa & Alasai & PRB J & JB \\
\hline Kunduz & Ali Abad & |PRB $\mid \mathbb{N}$ & $M Z$ \\
\hline Parwan & Bagram & PRB JJ & $\mathrm{JB}$ \\
\hline Badakhshan & Baharak & |PRB $\mathbb{N}$ & $\mathrm{MZ}$ \\
\hline Takhar & Bangi & PRB $\mathbb{N}$ & $\mathrm{MZ}$ \\
\hline Paktika & Barmal & IPRB $\mid K$ & KS \\
\hline Takhar & Chah Ab & PRB IN & $\mathrm{MZZ}$ \\
\hline Takhar & Chal (Baharak) & PRB II & MZZ \\
\hline Kunduz & Chardara & PRB & MZ \\
\hline Parwan & Dara Hazarah & PRRB & $\mathrm{JB}$ \\
\hline Takhar & Darqad & |PRB II & $\mathrm{MZ}$ \\
\hline Takhar & Dashte Qala & PRB & $\mathrm{MZ}$ \\
\hline Kunduz & Dashti-i-Archi & |PRB I & $\mathrm{MZ}$ \\
\hline Badakhshan & Faizabad & |PRB IN & $M Z$ \\
\hline Takhar & Farkhar & PRRB II & MZZ \\
\hline Paktika & Gayan & PRB |K & KSS \\
\hline Parwan & Ghorband & PRB & $\mathrm{JB}$ \\
\hline Paktika & Gomal & PRB & KS \\
\hline Kunduz & fmam Sahib & PRB & $\mathrm{MZ}$ \\
\hline Takhar & Ishkamish & PRB & $M Z$ \\
\hline Paktika & Jani Khil & PRB & KS \\
\hline Takhar & Kalafgan & PRB & ML \\
\hline Kunduz & Khanabad & PRB & IMZ \\
\hline Paktika & Khirkot & PRB & KSS \\
\hline Takhar & Khwaja Ghar & PRB & $\mathrm{MZ}$ \\
\hline Badakhshan & Kishm & PRB & IMZ \\
\hline Kapisa & Kohband & PRB & JuB \\
\hline Parwan & Kohi-Safi & PRB & JB \\
\hline Kapisa & Kohistan & PRB & JB \\
\hline Kunduz & Kunduz City & PRB & ML \\
\hline Kapisa & Mahmud-e Raqi & PRB & JB \\
\hline Paktika & Mata Khan & PRB & $\mathrm{KS}$ \\
\hline Paktika & Neka & PRB & KS \\
\hline Kapisa & Nijrab & PRB & JB \\
\hline Paktika & Omna & PRB & KS \\
\hline Kapisa & Panjshair(Anaba) & PRB & JJB \\
\hline Kunduz & Qala-e Zal & PRB & IMZ \\
\hline Takhar: & Rustaq & PRB & MLZ \\
\hline Parwan & Salang & PRB & JJB \\
\hline Paktika & Sarawza & PRB & KS \\
\hline Paktika & Serobi & PRB & $\mathrm{KSS}$ \\
\hline Paktika & Sharan & PRB & IKS \\
\hline Paktika & Sultan Khil & PRB & KSS \\
\hline Kapisa & Tagabs & PRB & JB \\
\hline Takhar & Taloqan & PRB & $M Z$ \\
\hline Paktika & Urgun & PRB & IKS \\
\hline Takhar & Warsaj & PRB & $\mathrm{MZ}$ \\
\hline Paktika & Wazakhwa & IPRB & $\mathbb{K S S}$ \\
\hline
\end{tabular}




\begin{tabular}{|c|c|c|c|}
\hline Province & District & IP & Rgn \\
\hline Paktika & Wormamy & TPRB & KKS \\
\hline Paktlka & Wormamy 11 & PRB & |KS \\
\hline Takhar & Yangi Qala & PRB & IMZ \\
\hline Paktika & Pousf Khil & PRB & KS \\
\hline Paktika & Zeruk & PRB & $\mathrm{KS}$ \\
\hline
\end{tabular}

\begin{tabular}{|l|l|l|l|}
\hline Wardak & Behsood & SCO & JB \\
\hline Ghazni & Jaghori & SCO & QR \\
\hline Ghazni & Malistan & SCO & QR \\
\hline Ghazni & Nawar & SCO & QR \\
\hline
\end{tabular}

\begin{tabular}{|l|l|l|l|}
\hline Nimroz & Chakhansur & VAR & QR \\
\hline Nimroz & Char Burjak & VAR & QR \\
\hline Nimroz & Dilaram & VAR & QR \\
\hline Helmand & Greshk & VAR & QR \\
\hline Nimroz & Kang & VAR & QR \\
\hline Nimroz & Khash Rod & VAR & QR \\
\hline Helmand & Marja & VAR & QR \\
\hline Helmand & Nadiali & VAR & QR \\
\hline Helmand & Nawa Barakzai & VAR & QR \\
\hline Helmand & Nawzad & VAR & QR \\
\hline Helmand & Sarban Qala & VAR & QR \\
\hline Nimroz & Zarang & VAR & QR \\
\hline
\end{tabular}




\section{MADERA LIVESTOCK SECTOR \\ Brief information regarding the establishment of vaccine production and diagnostic laboratories in Jalalabad}

\section{A Diagnostic Laboratory}

It is an accepted fact that the future of veterinary medicine in Afghanistan rests with the quality of the services it renders to Afghan society, especially under the present situation. The war stricken farmers and tired repatriates are looking hopefully towards each one of us. Any contribution at this stage can be a firm stride towards a constructive future for our veterinary vocation as well as the society.

Obviously the contribution offered by a network of veterinary diagnostic laboratory to achieve diagnostic services and epidemiological work can bring a great improvement in the quality of veterinary services.

The building up of the network will be a three phase process:

1. Physical establishment

2. Function establishment

3. Differentiation

MADERA has physically established a diagnostic laboratory which will be further developed. Right now the laboratory is ready to provide diagnostic services and some epidemiological screening of the important diseases.

The laboratory has all the facilities to isolate and identify the causitive agents on the basis of morphological, staining reactions, cultural characteristics, resistance, metabolism, biochemical reactions, antigenic structure and pathogenecity tests provided that we could obtain the necessary equipment, chemicals, antigens and antisera.

Furthermore, our laboratory has the facilities for diagnosis of Helmenlth parasite, protozoa and blood"parasites.

Since the laboratory is only in the initial phase of establishment, we hope to develop further our work to provide sufficient facilities to carry out confirmed diagnosis of viral diseases, at present it is only possible to rely on clinical sigins and gross pathological lesions.

\section{B Vaccine Production Laboratory}

Vaccination is one of the most important factors in prevention and control of diseases. The greatest care is inecessary in handling the vaccine between manufacturerand actual use on an animal, such care can be provided better as much as the distance can be 
shortened. Cost factor, transportation, loss of time, drawbacks in transportation, difficulties in on time implementation of campaign plans, breakage, etc. are many factors affecting effectivity of vaccines and hindering on time preventive measurements.

To avoid such drawbacks, MADERA found it feasible to establish a vaccine production laboratory to produce sufficient bacterial vaccines of its own needs in the first stage and perhaps the level of production can be increased in future.

You are most welcome to visit our network while you are in Jalalabad.

Dr. G. M. Arzo

In charge of vaccine production

and diagnostic laboratories 

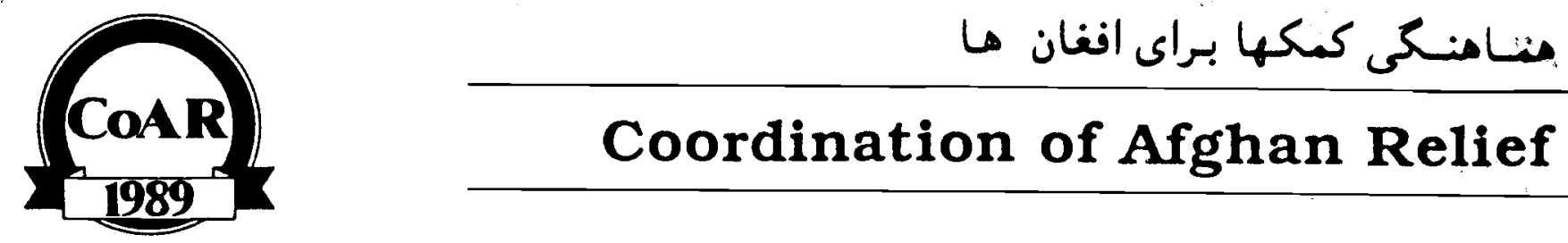

\section{Coordination of Afghan Relief}

To: $\quad$ Ahmad Jawed Ludin

ACBAR, Information Officer

From: $\quad$ CoAR, Veterinary Section

Date: $\quad$ 4th February 1997

Ref. \#: $\quad$ C/LTR/1016/97

Dear Mr. Ludin,

Enclosed please find a detail report of CoAR's animal husbandry and veterinary activities for the year 1996.

With best regards

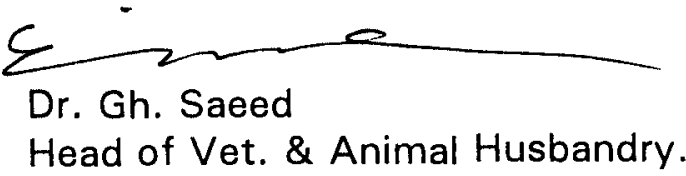

Coordination of Afghan Relief

House 93, Street 5, Sector N.3

House

Phase 4, Hayat Abad Peshawar 8290

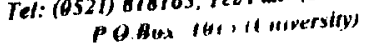

PESHAWAR

84 - E, Rehman Baba Road

University Town,

Tel : 41188

Fax : 44122

\section{GHAZNI}

House No. 56

Provincial Street,

Oararbagh Bus Station

Tel:
KABUL

House No. 184

Street No. 2, Road No. 15 , Wazir Akbar Khan Maina

Tel : 61246 


\section{Animal Husbandry and Veterinary Activities of CoAR during 1996}

\section{A. Veterinary Activities:}

CoAR has four veterinary clinics in Logar, Wardak and Ghazni Provinces. The activities of the clinics are as follows:

\section{Vaccination:}

A campaign to prevent animal diseases through vaccination was started by CoAR's veterinary department in Logar, Wardak and Ghazni Provinces. Some BVWs in the concerns areas were trained and then they assisted our paravets in the field. A total of 65000 different animals were vaccinated against Anthrax, Entrotoxaemia, black leg, Heamorrhagic septicemia and New Castle diseases. The campaign was started in May 1996 and was ended at the end of July 1996. It worth's mentioning that 11960 different animals were Vaccinated against the above mentioned diseases in our four veterinary clinics.

Cold chains were provided for all of our clinics in order to store vaccines safely. One gas refrigerator, two cold boxes and one thermos were given to each clinic.

\section{Animal examination and treatment:}

Animal examination is free of charge in CoAR veterinary clinics. The DVM doctor or Paravets give prescription after the examination and diagnose of the disease. The farmer is free to purchase the medicines from the clinics or from the bazaar. The clinics charge the farmer according to ACBAR policy (100\% of purchase price)

The O.P.D and observation of each clinics has shown mainly pmeumonia, fever, dysentry, colic, tympany, diarrhea. Endo prasites, endometritis, vaginitis, prolaps were also reported to certain extent. Foot and mouth diseases in cattle \& sheep and rabies in dogs were Among the infectious diseases reported in Logar Province. A total of 87415 different animals were examined and treated in four clinics during 1996. The number of families who have received veterinary services during 1996 was15705. CoAR veterinary department has spent Rs. 441,462 to purchase medicines, vaccines and surgery equipment for its clinics during 1996. One doctor (DVM) and four paravets are working in four clinics of CoAR.

The income of the clinics during 1996 was Afs. $64,997,314$. 


\section{B. Animal husbandry activities:}

\section{Establishment of sheep farm:}

CoAR has established a sheep farm in Shashqala in Wardak Province in 1994. A total of 50 Hazaragi sheep were purchased for breeding and wool production purposes during 1996.

Hazaragai sheep have wools of better quality and give birth up to three lambs at a time. The income of animal husbandry services during 1996 is reported in table one.

Table No. 1 Animal Husbandry Income in Afghanis.

\begin{tabular}{|r|l|r|}
\hline$\#$ & \multicolumn{1}{|c|}{ Description } & \multicolumn{2}{|r|}{ Amount in Afs } \\
\hline 1 & Selling of sheep and lambs & 6914000 \\
\hline 2 & Selling of animal manure & 865000 \\
\hline 3 & Selling of Skins & 374000 \\
\hline 4 & Selling of ghee & 5000000 \\
\hline 5 & Selling of wools & 682550 \\
\hline 6 & Selling of dried butter milk & 900000 \\
\hline & Total & 14735550 \\
\hline
\end{tabular}

\section{Sheep distribution for widows and orphans:}

CoAR distributed 200 sheep for 100 needy widows and orphans in Sayabad district in Wardak and Zanakhan district in Ghazni Provinces in August 1996. A survey was conducted by a team of three staff of veterinary department in order to find the needy persons. The rule and regulations for distribution shows that no widow can sell her sheep. Monitoring teams have to visit each widow and to see the sheep and its impact in the concerned community. A contract was signed between the representative of RDC and each widow. Taliban representatives were present during the signing of the contracts and sheep distribution. Each widow promised to not sell or slaughter female sheep. They can slaughter or sale the male sheep. CoAR has to provide the required vaccines for the sheep for a period of one year free of charge.

The first monitoring took place in November - December 1996 and the result of the mission indicated that $3 \%$ of the distributed sheep were slaughtered, $6 \%$ were sold, $9 \%$ had endo \& ecto parasites, $2 \%$ had pneumia and only $1 \%$ were dead.

The income of the widows from their sheep upto December 1996 was Afs. 588,735 and Afs. 500,300 in Ghazni and Wardak respectively. 


\section{Honey bees distribution:}

A survey was conducted to find the needy farmers in order to increase their income. Therefore, 30 boxes of honey bees were distributed to 15 families in Wardak and 10 boxes were distributed to 5 families in Ghazni Provinces.

\section{Cotton seed cake and mineral distribution:}

A total of $10450 \mathrm{kgs}$ cotton seed cake and $10700 \mathrm{kgs}$ mineral powder were purchased in 1995 and were distributed in 1996. It worth's mentioning that the price of distributed materials was $15 \%$ less than the market price and the number of the beneficiaries was 102 families. 


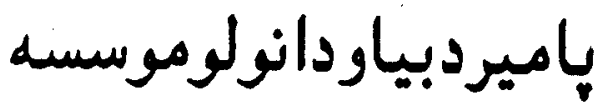

To

Date: 05 March , 1997

\section{The Director}

ACBAR

Sub. Enclosed Quick-review of PRB's Veterinary Program

Dear Mr Oharles

Please find herewith enclosed a copy of quick review of our Animal Health and Livestock Production Program. This paper will provide you with a short information on the situation of infectious diseases in the country, an update study of our achievements and some recommendations for further improvement of the program. I hope you will find the contents useful and informative.

PRB is looking forward for your cooperation and partnership to help better address rehabilitation and restoration of veterinary services in Afghanistan.

with thanks

sincerely Yours,

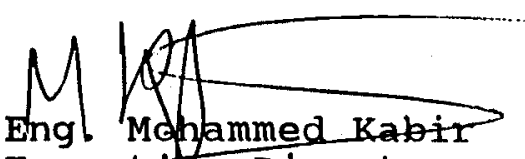

Execut Director

JFFICE: ' House No. 77-E, Rehman Baba Road, University Town, Peshawar - Pakistan.

Postal Address:

U.P.O. Box No. 765

Peshawar - Pakistan

Ph: 92.521.41641, 40701 
PAMIR RECONSTRUCTION BUREAU

( $P$ R B)

ANIMAL HEALTH \& LIVESTOCK PRODUCTION PROGRAM

\author{
VETERINARY SERVICES IN AFGHANISTAN
}

\title{
INTRODUCTION :
}

Livestock, as a major part of national wealth, is the most vital segment of agricultural sector being the back bone of Afghan segment of agricultural sector conomy. Providing living resources and employment opportunities,
the agricultural sector traditionally engages $85 \%$ population of this agrarian country.

In the pre-war period, before 1978, over $80 \%$ of foreign exchange brought to the country were generated through export of animal products such as Karakul, Wools, Rugs, Galeems, skins and intestines to international markets.

During the period of Russian invasion of the country and thereafter internal fighting, drastically damaing all social and economical

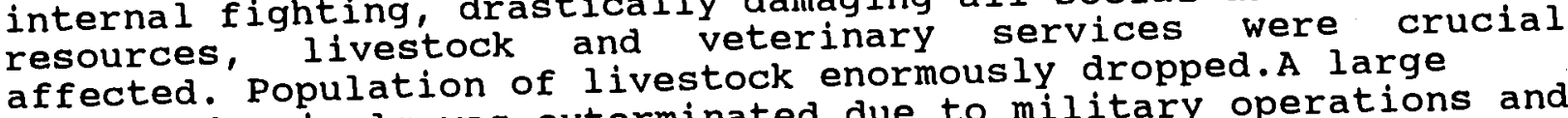
number of animals was exterminated due to military operations and land mines. Disruption and lack of veterinary services contributed to the escalated occurrence of livestock diseases, inducing higher losses of livestock.

In the prevailing devastating conditions, UNDP/FAO adopted a strategy to address the problems and sufferings of Afghan populace by rehabilitation and restoration of veterinary services in the by rehabilitation and restoration of veterinary program inside
country. Finally they initiated veterinary
Afghanistan, entrusted to a number of NGos including Pamir Reconstruction Bureau (PRB).

since then this organization (PRB) is vigorously engaged in provision of veterinary services inside Afghanistan to protect livestock against ailments and thus save enormous resources of the country. 
Pamir Reconstruction Bureau started activities in the field of veterinary in 1991, establishing 6 veterinary clinics inside Afghanistan. Currently this organization operates 54 veterinary clinics in various provinces as follows:

\section{Provinces}

1. Badakhshan

2. Takhar

3. Kunduz

4. Parwan

5. Kapisa

6. Paktika
No. of clinics

3

13

7

7

6

18

Total

54

The clinics are being operated on the basis of FAO/PRB regular structure \& setup required for activities. Technical staff entails veterinarian, Para-veterinarian \& Basic Veterinary Workers (BVW).

While setting up buildings of clinics, PRB facilitates logistic, technical support and other services required for operation of the clinics. In order to improve quality and to clinch efficiency of veterinary services, PRB regularly organizes refresher courses and additional training programs to all categories of technical field staff. For expansion of services in the radius of coverage of the clinics, it conducts training for BVWs for self reliance and their adhesion to veterinary activities.

\section{SITUATION OF INFECTIOUS DISEASES IN AFGHANISTAN:}

Observation and findings of our field veterinarian and FAO technical personnel, reveal that variety of infectious diseases prevalent in Afghanistan are inciting yearly tremendous direct and indirect losses of livestock. Amongst the most serious contagious and fatal diseases striking massive losses of livestock are Enterotoxemia, Anthrax, Caprin contagious pleuro pneumonia (CCPP), Contagious agalactia, hemorrhagic septicaemia, foot and mouth disease, strangles, sheep pox, infectious coryza, new castle, fowl pox, fowl cholera, coccidiosis, salmonella pullorum, chronic respiratory diseases (CRD).

The livestock is contemporarily being provided protection against the most dangerous and fatal diseases as stated above through regular vaccination campaigns and treatment extended by veterinary services conducted by PRB and other NGOs. 
Afghan farmers and villagers were not willing to vaccinate their animals and take advantages of veterinary services due to lack of their knowledge and awareness about importance of veterinary services in their life. Even when the services were extended free of cost. Operation of veterinary services, conducted by PRB and other NGOs and extension work of field personnel, have improved the situation. villagers and farmers are now accustomed to get vaccinated their livestock and utilize veterinary services and pay for the costs. Farmers and villagers have gotten complete awareness of the importance and benefits of veterinary services in their day to day life through extension work and operation of veterinary clinics.

Wide range of diseases (bacterial,viral, fungal, parasitic and others) of livestock are being diagnosed by field veterinarians on the basis of clinical grounds and extended necessary treatments accordingly.

\section{ACHIEVEMENTS OF VETERINARY SERVICES:}

Major world wide responsibilities of veterinarians are as follows:
a. Protection of livestock, part of national wealth, by preventive and curative veterinary measures.
b. Control of zoonoses and thus protecting human health.
c. Elevation of animal production (meat, milk and eggs) required for human diet.

Meat, milk and eggs, containing essential amino acids, are the most precious products of animals. Amino acids are having various functions in the body. They are necessary for growth, physical and mental development of human body. Their deficiency causes wide range of disorders such as undergrowth, anaemia, lower protection of body with subsequent increased affinity towards ailments, increased mortality of women \& children and others.

WHO standards estimates $35 \mathrm{gr}$. of animal proteins intake per 24 hours for an individual for normal growth and maintenance of activities. While FAO statistics in view of the existing resources of the world estimates possibility of only $27 \mathrm{gr}$. of animal proteins intake per individual for 24 hours. In the developed countries, with high level of animal production, the rate of animal proteins intake per capita is estimated 40 to $50 \mathrm{gr}$. per 24 hours. In contrast to this in developing countries, the intake rate of animal proteins per capita is estimated $14 \mathrm{gr}$. and even lass than that per: 24 hours.

Population growth of $1.7-2.2 \%$ per year and development of resources on $1 \%$ per year, obvious imbalance, indicates adverse news for inhabitants of our planet that they will face serious threat of hunger and calamity. 
The concept of compensating deficiency of animal proteins in human essential amino acids and thill not eliminate malnutrition of problem.

Afghanistan falling in the group of poor countries, hardly can provide intake of 14 gr. of animal proteins and even less per

This chart show the number of animals and their losses before 3 districts.

\begin{tabular}{|c|c|c|c|c|c|c|c|c|}
\hline \multirow[t]{2}{*}{ District } & \multicolumn{4}{|c|}{$\begin{array}{l}\text { Est imated number of Animals according to } \\
\text { livestock census conducted by PRB in } 1995 \text {. }\end{array}$} & \multicolumn{4}{|c|}{$\begin{array}{l}\text { Losses of livestock before operation of } \\
\text { veterinary services } 30 \% \text { est imated. }\end{array}$} \\
\hline & Cattle & Sheep/Goats & Equine & Poultry & Cattle & Sheep/Goats & Equine & Poul try \\
\hline Khoja Ghar & 12768 & 82719 & 5056 & 41613 & 3830 & 24815 & 1516 & 12485 \\
\hline Bagram & 8004 & 3467 & 1181 & 24896 & 2401 & 1040 & 354 & 7469 \\
\hline Jaji Maidan & 43036 & 18505 & 859 & 19529 & 12910 & 5551 & 257 & 5858 \\
\hline Total & 63808 & 104691 & 7096 & 86038 & 19141 & 31406 & 2127 & 25812 \\
\hline
\end{tabular}

vote: To calculate the value of each animal lost on the basis of current nilliards of Afs.

This chart shows number of animals and their losses in 3 district after pperations of Veterinary services in the area. It indicates that the number
ff losses has significantly decreased.

\begin{tabular}{|c|c|c|c|c|c|c|c|c|c|c|}
\hline Year & $\begin{array}{l}\text { Distric } \\
t\end{array}$ & $\begin{array}{l}\text { Type } \\
\text { of } \\
\text { Animal } \\
\mathrm{s}\end{array}$ & $\begin{array}{l}\text { No. } \\
\text { animals } \\
\text { in } \\
\text { district }\end{array}$ & $\begin{array}{l}\text { No. } \\
\text { Animals } \\
\text { vaccina } \\
\text { ted }\end{array}$ & $\begin{array}{l}\text { No. } \\
\text { animals } \\
\text { at risk }\end{array}$ & $\begin{array}{l}\text { No. } \\
\text { animals } \\
\text { affecte } \\
\text { d }\end{array}$ & $\begin{array}{l}\text { No. of } \\
\text { mortalit } \\
y \\
\text { animals }\end{array}$ & $\begin{array}{l}\text { No. of } \\
\text { animals } \\
\text { vaccinate } \\
\text { d \% }\end{array}$ & $\begin{array}{l}\text { No. of } \\
\text { animals } \\
\text { affected } \\
\%\end{array}$ & $\begin{array}{l}\text { Mortality } \\
\text { of } \\
\text { affected } \\
\text { animals } \%\end{array}$ \\
\hline \multirow{3}{*}{1995} & \multirow{3}{*}{$\begin{array}{l}\text { Khoja } \\
\text { Ghar }\end{array}$} & Cattle & 12768 & 4979 & 7789 & 2298 & 1276 & $39 \%$ & $18 \%$ & $10 \%$ \\
\hline & & $\begin{array}{l}\text { Sheep/ } \\
\text { goat }\end{array}$ & 82719 & 35155 & 47563 & 18198 & 12407 & $42.5 \%$ & $22 \%$ & $15 \%$ \\
\hline & & $\begin{array}{l}\text { Poultr } \\
y\end{array}$ & 41613 & 8072 & 33540 & 14564 & 12483 & $19.4 \%$ & $35 \%$ & $30 \%$ \\
\hline \multirow{3}{*}{1995} & \multirow{3}{*}{ Bagram } & Cattle & 8004 & 2625 & 5378 & 1325 & 960 & $32.8 \%$ & $16.5 \%$ & $12 \%$ \\
\hline & & $\begin{array}{l}\text { Sheep/ } \\
\text { goat }\end{array}$ & 3467 & 1397 & 2069 & 658 & 485 & $40.3 \%$ & $19 \%$ & $14 \%$ \\
\hline & & $\begin{array}{l}\text { poul tr } \\
y\end{array}$ & $24896^{\circ}$ & 11950 & 12945 & 9958 & 8962 & $48 \%$ & $40 \%$ & $36 \%$ \\
\hline \multirow{3}{*}{1995} & \multirow{3}{*}{$\begin{array}{l}\text { Jaji } \\
\text { Maidan }\end{array}$} & Cattle & 43036 & 11490 & 31546 & 8521 & 6025 & $26.7 \%$ & $19.8 \%$ & $14 \%$ \\
\hline & & $\begin{array}{l}\text { Sheep/ } \\
\text { goat }\end{array}$ & 18505 & 8604 & 9900 & 3705 & 2960 & $46.5 \%$ & $20 \%$ & $16 \%$ \\
\hline & & $\begin{array}{l}\text { poultr } \\
y\end{array}$ & 14529 & 4784 & 14744 & 6835 & 6054 & $24.5 \%$ & $35 \%$ & $31 \%$ \\
\hline
\end{tabular}




\section{CONCLUSION :}

Going through the above mentioned charts (I and II), it appears that before the initiation of veterinary services losses of livestock were approximately $30 \%$ per year due to the existence of foci (endemic) of various infectious diseases in the area. Now after five years operation of veterinary services, the losses have reduced to approximately 10-16\% in cattle and sheep/goats per year, as the foci of various infectious diseases have been controlled and reduced.

It means that livestock holders were losing milliards of Afs, each year before the operation of veterinary services. Thanks to those services, Afghan farmers are now saving milliards of Afs, each year sine then.

\section{RECOMMENDATIONS :} $\cdots$

1. Since there is no representative of central government in Afghanistan, the ongoing veterinary services are vitally needed to prevent losses of livestock, part of national wealth, these services would be necessary to be continued.

2. Ensuring effectiveness and better quality of veterinary services, laboratory facilities would be necessary to be established in different localities in Afghanistan to help field veterinarians in diagnostic techniques of diseases so far not detected.

3. To increase animal production in Afghanistan, which is in the lower range for various factors, it is necessary to improve local animal breeds mainly cattle by reintroduction of artificial insemination and improvement of : traditional feeding.

4. Pastures, as feeding source free of cost, would be imperative to not only preserve but also to improve. Further more drinking water sources for livestock would be vitally needed and would be possible to made it available nearby pastures through digging wells.

5. The increasing incidence of external parasites, causing enormous indirect losses, would require to be tackled with arranging pools for showering animals.

6. In the localities with limited agricultural lands, poultry rearing would be the only potential alternative to be adopted.

7. Short term courses, seminars and workshops would be necessary to arrange for farmers in practical aspects of the 1 ivestock management and poultry. 
8. Traditional feedings could be improved through introduction of simple techniques of non traditional feedings such as silage making, treatment of straw with urea etc. by practical demonstrations and extension activities.

9. To minimize the risks of transmission of infectious diseases, arrangements for quarantine and control of livestock moving from one place to another place would be necessary, specially at the borders areas.

10. Besides improvement of knowledge of veterinarians in technical matters, special attention would be necessary to be paid to the practical aspects of livestock management on the refresher courses being provided to field veterinarians. organizing refresher courses 


\section{ACBAR \\ MINUTES OF VETERINARY SUB-COMMITTEE MEETING \\ 16 JANUARY, 1996}

\section{APPROVAL OF THE AGENDA AND MINUTES OF THE LAST MEETING}

The Deputy Chairman welcomed participants to the meeting and wished them a happy new year. He hoped that this year would be a year of peace and success for Afghanistan, and also wished success for the veterinary activities.

Several changes were made to the minutes of the last meeting. The revised minutes are attached.

The agenda and minutes were then approved.

\section{ANNOUNCEMENTS}

MADERA announced that after some problems with the Pakistan Government, they moved their office to Jalalabad. Eight members of the agency are based in Peshawar.

MADERA also announced that a vaccination campaign was conducted in Kunar, Laghman and Noristan provinces. MADERA has produced 156,000 doses of CCCP vaccines and used 126,000 doses in the vaccination campaign. The vaccination campaign was for 10 days. MADERA added that medicines were charged at $100 \%$ without any problems.

FAO said that they are currently discussing medicine supply and looking into ways of encouraging manufacturers to provide medicines inside Afghanistan. FAO added that they do not want to directly be involved in this issue, but would like to encourage individual manufacturers to get involved.

FAO said that being successful in charging for medicines since 1992, they have decided to charge for Sheeppox vaccines. The demand of this particular vaccines is high and it is hoped that the decision will be successful. A minimum price for 1 dose is Rs. 0.6.00. The money generated from the sale of this vaccines will be used to purchasing other vaccines.

This decision was taken in light of insufficient funds available for vaccines.

ACBAR inquired if the decision was taken and discussed with the NGOs working in veterinary field.

FAO clarified that they have discussed it with the EU, GAF and the Dutch Committee for Afghanistan.

NGOs having any comments on this issue should inform ACBAR or bring it up at the next meeting.

\section{PRESENTATION ON EXTENSION SERVICES - BY DR. SAMSOOR, DCA}

Dr. Samsoor briefed the meeting on the background of the extension services. He said that initially 2 people were appointed with the aim of enhancing communication and technical skills and providing awareness among the farmers. 
Several charts, leaflets and booklets were prepared for this purpose. He further elaborated on the various publications displayed at the meeting.

Dr. Samsoor said that the extension messages, especially in colostrum feeding and rabies preventive measures were well received by farmers.

FAO asked about the outcome of the programme and farmers reaction.

DCA said that they faced several problems in different parts of the country, but the vaccination messages and prevention of mortality proved to be successful.

FAO asked if there was any evidence about the proposed design of stables with ventilation that was accepted by farmers.

DCA said that some areas were effective, but the outcome is not 100 .

Another query from FAO as to which messages were well accepted by farmers, DCA said that the vaccination, colostrum feeding and the stray dogs elimination were very successful in most of the areas.

\section{ANY O'THER BUSINESS}

Solidarites has worked in Jalrez in agriculture sector since 5 years. A permanent center was established in the area last year. The activities of the center are; seed distribution for multiplication, training of farmers through extensionists and collating field problems. The extensionists sometimes bring livestock problems from the fields. Solidarites said that DCA has three Vet. clinics in the district, but only one is active. There is no functioning center to advise or resolve farmers problems.

The agency brought this matter to the attention of the veterinary sub-committee, since they were approached by the people of the area.

FAO thanked Solidartes for the information and said that ADA has taken over those clinics and suggested that any problems with regards to veterinary activities in that area should be addressed to ADA in the future.

\section{Participants:}

Dr. Tahir D. Chairman

Dr. A. Ghafoor

Dr. G. Saeed

Wynn Flaten

Dr. M. Halimi

Dr. Mehraban

Liz Spincer

MADERA
GAF
COAR
A-AID
FAO
FAO
ACBAR

Dr. Faiza Zara

Eng. Esmat

Dr. Samsoor

Dr. M. Kazem

Dr. Terence Barker

Mohammad Hashim

Naqib A. Noory
UNOPS

ADA

DCA

PRB

FAO

Solichrites

ACBAR 


\section{ACBAR \\ VETERINARY SUB-COMMITTEE MEETING}

13 February, 1996

i. APPROVAL OF THE AGENDA AND MINUTES OF THE LAST MEETING

The minutes of the last meeting were criticized for not including some of the important points discussed.

The term CCCP should read CCPP in the agenda as well as the minutes of the last meeting.

Item II, para 2, line 3, should read 137,000 not 126,000 .

Item III, para 1, should read 5 persons will be appointed for extension services (not 2 persons).

\section{ii. $\quad$ ANNOUNCEMENTS}

ADA has recently taken over the responsibility of running 7 (VFUs), previously run by DCA. ADA expressed thanks to DCA for not picking up some office tools and materials within the VFUs.

ADA also supports 16 other clinics in Zabul, Kandahar and Urozgan provinces. School Based Agriculture Awareness project is run in all of the said areas.

ADA requested all NGOs to cooperate with the awareness project.

The representative of Solidarities will be leaving for Kabul shortly and then to Jalrez, Wardak. He asked the members if they have any messages or else to be conveyed.

PRB will have a presentation on activities in the north-east (Kunduz, Takhar and Badakhshan), for the next meeting. Writing information will be made available in advance. 
Postponed for the next meeting.

PRB had congratulated MADERA for initiating production of CCPP vaccine, through a letter circulated with the minutes of the last meeting. The letter also included some queries regarding the vaccine.

MADERA stated that they have not received the letter.

MADERA will have a detailed presentation at the next meeting and will answer any question arisen, accordingly.

FAO was criticized for its new policy of charging for Sheeppox vaccine. It was said that farmers are ready to pay for medicine and clinic fee for their diseased livestock, but it will be very difficult to convince them to pay for vaccination of their healthy animals as well.

DCA said that they have not been consulted regarding the issue, as mentioned by FAO in the last meeting.

DCA criticized FAO's charging policy and stressed that shortage of fund for vaccination should not lead to a change in policy. They should instead seek funds from donors, as $90 \%$ of other agencies, e.g. EU, etc. provide funds for vaccination to be served freely.

Furthermore, it will cause confusion among farmers, and will create problems for NGOs selling vaccines.

MADERA opposed the new policy and said that such decisions should be made in consultation of concerned organizations.

The representative of FAO said that since $\mathrm{FAO}$ is going to privatization process of activities, such policy could be justified. Now farmers are satisfied with payment for medicine and clinic fee, they were unwilling to pay for it at first though. The payment for vaccine will also get to be acceptable for farmers gradually.

Regarding the decision to charge for Sheeppox vaccine, more particularly, FAO acknowledged that the exercise was experimentally launched, since demand for Sheeppox vaccine was high while fund was very low. After observation of the outcome, the policy could be modified. This policy is not applicable for other vaccines yet. 
More discussions on this issue will take place at the next meeting, wherein more involved staff from FAO should attend the meeting.

Prof. Zimeray from PRB suggested that the Veterinary Sub-committee should meet twice a month. .He supported discussions on technical and scientific issues, relevant to the sub-committee, in the meetings.

NEXT MEETING:

The next Veterinary Sub-committee meeting will be held on Tuesday 12 March 1996, at 9:00 hrs, at ACBAR conference room.

Chaired by: Dr. M. S. Tahir MADERA

Minutes by: A. Jawed Ludin ACBAR

PARTICIPATED BY:

Eng. Esmat ADA

Tino Hennecken DCA

Dr. Ghulam Saeed

Dr. A. Osmani

Dr. Samsor DCA

Dr. Zimerai PRB

M. A. Salemi

CoAR

Dr. Mohd. Kazem

FAO

M. Hashim Mayar Solidarities

Safi

PRB

Dr. Attaullah

GAF

A. Jawed Ludin

ACBAR

M. Karim Rahimi

PRB

$\mathrm{ADF}$

- ACBAR 


\author{
VETERINARY SUB-COMMITTEE MEETING \\ 12 March 1996
}

\title{
I Approval of the Agenda and Minutes of last meeting.
}

Minutes of the last meeting were approved. It was agreed to move point VI of the agenda to point III, Chairman Election.

\section{Announcements.}

PRB issued a copy of their 1995 Activity Report to the meeting. They thought it important to discuss this as it has a lot of technical points and ACBAR should be kept informed of what is going on .

It was agreed that the whole document could not be discussed at this time but will be an agenda point at the next meeting. If anyone has any questions or queries they can be raised at that time. If you need a copy of this report contact Dr salemi at PRB.

\section{Election of new Chairman.}

Dr Salemi, PRB, on behalf of the committee, thanked the Chairman for all of his work in the past year. These thanks are being passed through the minutes as the Chairman was unable to attend today's meeting.

Dr. Zimeray, PRB nominated Dr Salemi as the new Chairman. There were no other nominations or any objections to this.

The new Chairman of the Veterinary Sub-committee is Dr Salemi, PRB.

\section{Update on Vaccine Laboratory by MADERA.}

A two page letter was handed out at the meeting and some time allowed for: everyone to read it.

MADERA pointed out that it was about Vaccine production not the Laboratory. They are trying to produce some CCPP auto vaccine in Afghanistan. So far they have been successful in this and many farmers have inoculated their goats. Production is very simple and all possible precautions are taken to prevent contamination. 
PRB queried whether it was possible to ensure purity of the products and asked if there was any testing or quality control. PRB would like to see International standards being applied.

DCA pointed out that MADERA are doing a good job and trying to improve conditions within a very limited budget. The quality of the auto vaccine may not be as high as an International vaccine but it did appear to be working.

PRB once again highlighted the dangers of contamination and if the auto vaccine was not pure, it may not kill the animals but could make them immune to the vaccine which could cause even more problems.

A-AID suggested that in the situation as it is at present within Afghanistan there is nothing that meets International standards, much as we would like them to. MADERA are doing an excellent job and taking the initiative to instigate new projects and try to help the farmers and therefore the community.

It was agree that a technical discussion would be no good at this point and a work Group should be set up to:

a. Monitor the results of using the auto vaccine by visiting farmers and asking their opinion.

b. Check the laboratory conditions and procedures used.

The Work Group will be made up by:

Dr Usmani, FAO

Daud Mohammad, ADF

Dr Anbergul, GAF

Dr Shafiq, MADERA

Dr Salemi, PRB

Dr Salemi and Dr Usmani will prepare a draft Terms of Reference for the group to be discussed and finalised at the next Sub-committee meeting.

\section{Technical Qualification of Extension Workers by DCA}

This point was addressed at the last meeting however Dr Samsor was good enough to explain briefly, the qualifications of their extension workers and how this programme was first initiated.

The programme was very low level and consisted of workers communicating with farmers regarding vaccinations and medications. This slowly progressed to the employment/training of extension workers.

Extension workers shokld have completed 12 th grade education before being accepted. They are then given basic veterinary training before going out in the field. They talk with farmers and give 
advice on basic animal care, they also listen to the problems being faced by the farmers and try to help them. Vaccination of animals is encouraged at all times. The workers report any new problems to their office and seek advice
when necessary.

As an ongoing part of their training veterinary matters are discussed and briefings held with Dr Samsor. It was questioned if basic training was enough and whether they
should have technical experience.

Dr Tino pointed out that the work they were doing was very communication skills which camportant qualification was good

\section{Sheeppox vaccine sale policy - by FAO}

FAO, due to reduction in funding are unable to give free vaccine this year and have been told by their donors that they will have to
sell it.

DCA and others strongly disagree with this as vaccine is too important and issue to hope that the farmers can afford to pay for it. How do you convince a poor farmer with healthy animals that he has to pay money for something that might happen.

DCA are waiting to hear from the European Union if the funds they have requested for vaccines are approved and hope to know by the the of this month. If they are successful FAO will then discuss the matter of free vaccine with DCA and EU.

\section{Any other Business}

PRB pointed out that there were a few alterations he would like to see in the DCA newsletter. He will write to them on the matter.

There was no other business the meeting was adjourned.

Next meeting of the Veterinary Sub-committee will be Thursday 11 th
April 1996 at 9.00 am, ACBAR Conference Room. 
Present

Dr M S Tahir

Dr Mehraban

Eng. Esmat

Dr Saaed

Dr Mohd A Salemi

Dr Zimeray

Dr Attaullah

Safi

Dr Tino

Dr Samsor

Wynn Flaten

Dr Tahir

Liz Spencer
MADERA (Deputy Chairman)

FAO

ADA

COAR

PRB

PRB

GAF

$A D F$

DCA

DCA

A-AID

MADERA

ACBAR 


\section{Veterinary Sub-committee Meeting}

\section{Held on 11 April, 1996}

Dr. Salemi, PRB, thanked the members for electing him as chairman, and hoped that the sub-committee will run properly.

\section{Approval of the agenda and minutes of the last meeting}

\section{Agenda: \\ Approved.}

\section{Minutes:}

The last sentence in the first paragraph of 2nd page, should read, "PRB would like to see the possibilities of observing International Standards, so production could be improved."

\section{II. $\quad$ Announcements}

DCA announced that their training center in Charikar is starting its course from August 1996. Agencies are asked to nominate members for the center not later than end of April. Placement test will be taken in July.

FAO suggested that DCA should select trainees from the local areas and in order to ensure avoiding overlap, particularly, people from Nangarhar, Kunar, Logar and Kabul provinces should not be considered since $\mathrm{F} A \mathrm{O}$ has trained big numbers of paravets in the said provinces. The suggestion does not include holding upgrading or refresher courses for FAO trained paravets."

\section{Terms of Reference for CCPP Vaccine Production}

A handout of the Terms of Reference for the Work Group, prepared by FAO, was circulated to the members, and some tine allowed to read it and then comment. (Attached please find a copy of the Terms of Reference.)

"Dr. Amber Gul from GAF, as decided in the last meeting to accompany the working group in the monitoring mission, will be replaced by Dr. Haji Malang, GAI", I $\Lambda \mathrm{O}$ stated.

MADERA suggested the lirst line, paragraph 4, page 1, to read "by the MADERA lab only in November and December".

DCA suggested that infection trail should be included in the Terms of Reference. Dr. T'incexplained that for the infection trail three groups of animals should be brought together in a control room; 
diseased animals, vaccinated animals and healthy (not vaccinated) animals. The vaccinated animals will not be infected, if the vaccine works, while the contagious disease will infect the rest of healthy animals.

Since this exercise will emerge to be too costly, MADERA was unable to afford it. To this end, FAO, considering the signilicance of the issue, said that they will look to find and allocate some budget for this purpose.

Since DCA keeps contacts with some institutes in Holland, they were requested to assist MADERA in supplying samples and securely transporting it to Holland to be examined.

After the 'Terms of Relerence were approved, members were asked to come up with a fixed time for commencing the monitoring mission. As ultimately decided, members of the working group will come together on Monday morning, 3 June 1996 at MADERA's office in Jalalabad. From there they will start their mission. 'The mission will take two weeks and after returning the work group will report the outcome to the Veterinary Sub-committee.

MADERA will provide transportation for the team as well as all required information. FAO will pay DSA for MADERA's staff; the rest of the group members will receive DSA from their own agencies.

In the next meeting, DCA will decide whether or not somebody from DCA will accompany the monitoring mission.

\section{Update on Sheeppox Vaccine Sale Policy}

DCA reported that the EU response to approval of funds for vaccination is still awaiting, so nothing could be discussed with regards to the vaccine sale policy. Once funds are available, sale policy will be completely disagreeable, yet agencies will have got no other choice if there is no fund. Notwithstanding the total unavailability of funds the sale policy should be fixed at a scale acceptable for farmers. DCA stressed that, initially, the sale policy should be widely publicized.

FAO reasoned that there is no source that could ensure availability of medicine in Afghanistan. Only the aid community should take care of it. FAO started the sale policy with charging $50 \%$ of the cost for Sheeppox vaccine. This has been a major success and it has not only greatly assisted the agency income, but also the number of farmers, referring for vaccination, has increased.

The issue of cheating in medicine sale was raised as an adverse problem being faced. Private dispensaries sell non-standard and expired medicine, definitely with a lower price than the standard medicine sold by NGOs. Unfortunately, farmers are mostly attracted by the lower price. FAO stated that they have taken some steps against this problem. PRB pointed out that this could be avoided through proper monitoring of VFUs or efficient extension service with willingness to keep in touch with farmers and find out their difficulties.

MADERA reported that cheating in medicine is a real problem, in Pech and Kamdesh districts of Kunar, which has emerged since the privatization of activities has occurred. MADERA considered training of BVWs to be ineffective. Approving the last statement, Prof. Zimeray, PRB, said that training $13 \dot{V W}$ s could create problems for veterinarians in field.

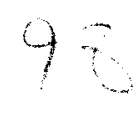


Though it was believed that only a stable government policy can remove these problens, the most the aid community can do is to regularize their structure of activities and stop the chances for medicine cheating.

\section{PRB Activity Report}

The report was circulated at the last meeting, and most of the participants had read it. The nembers were asked for comments.

It was said that the member agencies should report their relevant sectoral activities as quarterly, six monthly or yearly to the sub-committee meetings, so that coordination could be further strengthened.

ADF queried about some points in the PRB report, and was provided with answers by PRB representatives.

\section{Any Other Business}

MADERA reported but did not approve the claim of their microbiologist that the two sero type Mycoplasma has been identified in their Laboratory, but this was strongly contradicted as it was believed that identification of Mycoplasma is poorly possible even by the advanced and well equipped laboratories in Peshawar and Lahore.

In response to a question regarding the literature used by their laboratory, MADERA said that the technicians use new literature, though not provided by MADERA yet. MADERA asked the involved agencies for useful advice instead of criticism.

Based on a news article, in Daily Pameer Peshawar - issued on Tuesday 9 April 1996, it was reported that Kabul University intends to conduct an international seminar in Kabul on $15 \mathrm{July} 1996$. Delegations from many countries are expected to attend. Social, economic, cultural, development, rehabilitation, etc issues are going to be discussed. The seminar will last for ten days.

It was suggested that ACBAR, soon after the return of Executive Director and Programme Manager from Kabul, should contact Kabul University and ask for possibilities of the sub-committee member agencies participation in the seninar. The result will then be acknowledged to the members.

F $O$ reported that they have printed manuals for VFUs, while BVWs have already got the ir manuals. $A$ two week refresher course for 478 paravets will follow. $\mathrm{F} A O$ had planned to prepare a quarterly activity report, but has so far failed to do so.

FAO also reported that they have got clearance for their projects in Mazar-i-Sharif. More than 300 people have died from Rabies.

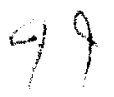


The representative of $\mathrm{A} \triangle \mathrm{O}$ said that the IIealth Department in Jalalabad has registered 19 cases of dog bitten hunan in one day. To this end, Rabies prevalence is approved in the eastern zonc.

On 15 May 1996, I:AO is starting a Rabies vaccination campaign in the eastern region. WHO will provide human vaccine freely, while FAO will provide dog vaccine to veterinarians and paravets in all clinics. The responsibility of local government is to kill stray dogs. The staff of the local government will receive wheat from WFP. FAO intends to extend this campaign to Khost, Kandahar, Paktia, etc.

In the next meeting, PRB will have discussion on the situation of veterinary, nutrition and livestock in Badaklıshan. The discussion will cover ideal plans for the future.

Members were asked to contact $\triangle C B A R$ secretariats in case they want any special item/subject to be included in the agenda for the next meeting.

NEXT MEETING: THENEXT VETERINARY SUB-COMMITTEE MEETING WILL BE HELD ON THURSDAY, 9 MAY 1996, AT 9:00 AM, IN ACBAR CONFERENCE ROOM.

Chaired by: Dr. M. A. Salemi, PRB

Minutes by: A. Jawed Ludin, ACBAR

\section{Participants:}

Dr. Mehraban

FAO

Dr. Ghulam Saeed

COAR

Dr. M. S. Tahir

MADERA

Mr. M. J. Emal

MADERA

Dr. Tino

DCA

Dr. Samsor

DCA

Dr. Zimeray

PRB

Dr. Nazir A.

PRB

Mr. Safi

ADF

Dr. A. Ghafoor

GAF

\section{Absent agencies:}

A-AID, ADA, ARDA, AWRC, BBC, EU, NPO/RRAA, RAFA, UNOPS

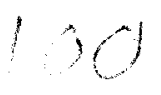




\section{ACBAR}

\section{Veterinary Sub-committee Meeting}

\section{Held on 9 May 1996}

The chairman welcomed the participants and appreciated their great interest shown to come up with an effective meeting.

I. Approval of the agenda and minutes of the last meeting

Agenda:

Approved.

Minutes:

FAO made some corrections to the minutes:

Dr. Tino ${ }^{\circ}$ name was miss-spelled in the last paragraph of the first page - ACBAR secretariat apologized for that.

Mr. Barker disagreed with the first and second sentences of the second paragraph, under item IV. He reasoned that aid community is not supposed to be the only authority to ensure availability of medicine in Afghanistan.

The third sentence of the same paragraph should read, "UN started charging policy ..."; besides, the last sentence of the paragraph should read, "This has been a-major success and it has not only greatly assisted the programme financing, but also the number of farmers, having received vaccination facilities, has increased."

The last paragraph in page 3 should read, "FAO also reported that they have got clearance for the extension of the Rabies project in Jalalabad, Mazar-i-Sharif and Khost. More than 300 people have died from Rabies in the northern provinces.

\section{Announcements}

DCA circulated a job announcement for a vacant position of Trainer within DCA. Dr. Tino said that preference will be given to bearers of qualified veterinary knowledge and experience, not to fluency in English, as quoted in the announcement. (The job announcement is attached)

\section{$\star 1 / 4$ *}

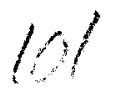


DCA, as well, announeed that they have reopened their medicine dispensary store in Ghazni. The aim is for the NGOs to avail good medicine with lower price than market. Medicine will be distributed to those veterinarians and BVWs of NGOs who refer for registration first. The registrations will be kept as records for future distributions.

In response to some questions from the floor, DCA said that pricing policy for the medicine has not been finalized yet. Once finalized, the pricing will be let be known to the members. Regarding establishment of similar stores in other provinces, DCA said that possibilities will be sought in Jalalabad, for cxample; though veterinarians from any provinec could get registered with and receive medicine from the store in Ghazni.

DCA asked if FAO could provide them with lists of veterinary staff of NGOs in Ghazni, Paktia and Paktika provinees to be covered by the medicine store in Ghazni. FAO responded that, as for now, it is unlikely to be possible, sinec FAO's database has not been completed yet.

GAF announced that they intend to establish two stores in Jalalabad and Khost. GAF would like to coordinate with DCA.

DCA, accordingly, stressed on coordination so that avoiding duplication could be ensured.

FAO announced that their Rabies vaccination campaign will be started on 15 May 1996. Vaccines have already been supplied. The campaign will cover village to village vaccination, and will continue for 3 to 4 months. Vaccination will be carried out through VFUs; and dog owners will be charged for. In response to a question regarding stray dogs, FAO said that stray dogs will either be shot or poisoned.

\section{Follow up on the Working Group monitoring mission}

Although, the concerning issues to the Working Group and monitoring mission were discussed, in details, in the last meeting, there was still need to include the follow up of the issue in the agenda for this meeting. DCA, in the last meeting, did not finalize the decision if DCA would let a representative accompany the Working Group in the mission.

DCA disclosed that nobody from their organization will take part in the monitoring mission. DCA excused for any inconvenience it might have caused.

\section{Veterinary/nutrition/livestock/general situation in Badakhshan, by PRB} Attached please find a Study Paper on the Nutrition Aspect of Badakhshan Province,
prepared by PRB.

Along with circulating the study papers, Prof. Zimeray, from PRB, abstractly bricfed the floor on the critical living conditions in Badakhshan. He, then, called on the aid community to

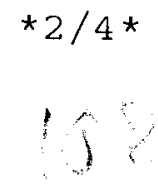


address the needs of the poor province. Given the fact that Badakhshan, as compared to other provinces, has a big number of educated women, conducting home based economic programmes were, particularly, stressed on. PRB said that the study paper is prepared to draw the attention of donors.

FAO said that they have submitted proposals for funding of 10 clinics in Badakhshan to UNOCHA. FAO is not sure, taking the unsteady funding conditions into account, if the clinics could survive/be sustainable in this province.

Afghanaid reported that two of their successful programmes had been approved and implemented based on personal approach by some individuals within the organization staff. An apiculture project in Badakhshan, with outstanding outcome and raising demand for honey, proved to be very successful. Another programme was poultry project in Charikar, which was successful as well. One of Afghanaid's staff is in Badakhshan now looking after a BVW training programme. He is expected to come up with good suggestions.

Afghanaid has no clinic in Badakhshan, yet a BVW training programme will be conducted in the coming summer. Medicine and required supplies will be transported to the province from Peshawar.

Focusing on page 9 of PRB's study paper, Director of Afghanaid considered the recommendations and recounted the relevant achievements by Afghanaid.

Prof. Zimeray from PRB was interested in individual approach to Afghanaid to get the relevant issues discussed.

\section{Any other business}

CoAR reported that they plan to establish a sheep raising farm in Wardak with an initial capacity of 50 sheep. CoAR has sent the concept paper of the project to FAO, asking for assistance and professional consultation, sinee this has been COAR's first-ever experience in this field.

CoAR added that it is an experimental farm aimed at raising wool production from the local breed, as well as conserving the breed. Lambs will be sold in subsidized prices.

FAO said that their is no allocation for livestock within FAO, therefore, CoAR could not be provided with FAO assistance.

FAO requested, if any agency have a survey on household consumption of animal productions, to provide FAO with a copy of the survey results.

In response to FAO, PRB expressed that they have completed a survey on the similar purpose in Paktia province. The survey documents are still in Dari draft stage and have not

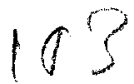


been finalized, but based on FAO's insistent request, PRB promised to provide a copy of the results.

The chairman requested the members to contact ACBAR secretariat in case they want any special item/subject to be included in the agenda for the next meeting.

NEXT MEETING: THE NEXT VETERINARY SUB-COMMITTEE MEETING WILL BE HELD ON THURSDAY, 20 JUNE 1996, AT 9:00 AM, IN ACBAR CONFERENCE ROOM.

Chaired by: Dr. M. A. Salemi, PRB

Minutes by: A. Jawed Ludin, ACBAR

\section{Participants:}

Dr. A. Ghatoor

Dr. M. S. Tahir

Wynn Flatten

Dr. Samsor

Dr. Tino

Terence J. Barker

Sediqullah

Dr. Nazir Ahmad

Dr. Zimeray

Dr. Ghulam Saced

Eng. Esmat

GAF
MADERA
Afghanaid
DCA
DCA
FAO
FAO
PRB
PRB
CoAR
ADA

GAF

MADERA

Afghanaid

DCA

DCA

FAO

FAO

PRB

ADA

Absent agencies:

ARDA, AWRC, BBC, EU, NPO/RRAA, RAFA, UNOPS 


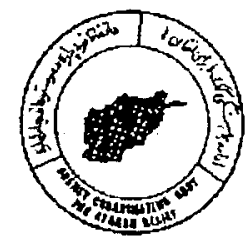

\section{ACBAR}

\section{Veterinary Sub-committee Meeting}

Held on 20 June 1996

The chairman introduced the agenda for the meeting after welcoming the participants.

I. Approval of agenda and minutes of the last meeting

Agenda:

Approved.

Minutes:

The last sentence, last paragraph, under item II, Announcements, in page 2, should read, 'In response to a question regarding stray dogs, FAO said that stray dogs will either be shot or poisoned by the local authorities'.

'Paktia province' in the last paragraph, page 3, should read Khost province.

\section{Announcements}

COAR announced that they have received reports from Baraki Barak district, Logar province indicating existence of some cases of Rabies and FMD. Reports add that 19 cattle have been bitten by Rabies dogs in Abdul Hakim village, while other four cattle were bitten in Babur village. The cases of FMD (Foot and Mouth Disease) are seen in sheep in nomad families.

FAO announced that Rabies vaccination campaign has been started in the eastern provinces. The key implementing partner agencies are MADERA, GAF, etc.. About 14 selected districts in 3 provinces of the region have been covered. The programme is still continuing and more districts in the region will be covered.

In response to a question regarding extension of the programme to other provinces, FAO said that facilities for extension of Rabies vaccination campaign exist, but still clearance is needed. This programme will be expanded to Logar, Paktia, Khost, and other provinces.

MADERA, regarding the vaccination campaign, disclosed that one of the problems faced by vaccinators was charging money for the vaccine, which was unexpected for people who had no experience of MADERA's charging for vaccine previously. Nevertheless, in general, it was believed to be ar good start for the charging policy.

III. Report on field observations / monitoring mission to Kunar (Production of CCPP Auto vaccine by MADERA)

The chairman, who had been a member of the monitoring mission, shortly briefed the floor on their trip to Kunar. The members of the working group had to undertake long and difficult hiking. They visited many villages and interviewed flock owners. MADERA's lab, and lab personncl were also visited. (The report of the monitoring mission is attached)

Both Dr. A. Osmani and Dr. Salemi had prepared mission reports that were fairly similar to each other: Mission's report was circulated to the floor and some time was allowed for

\section{$1 / 4$}

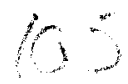


them to read the conclusion and recommendations.

Dr. Osmani introduced and explained some parts of the report. MADERA's work was generally considered valuable and appreciable, yet in many aspects improvement was deemed necessary.

A question arose from the floor regarding whether Dr. Osmani would, based on observations of the mission, recommend that MADERA should continue local production of CCPP auto vaccine from the local strains, of course, assuming that no other possibility of improvement, including donor assistance, would exist.

Dr. Osmani, in response, recommended continuation of the vaccine production, but he believed that for MADERA to continue this process, it is necessary to amend and improve the ill points; some recommendations to be considered are included in the report. Dr. Osmani added that the mission, including him, was assigned to go, see and collect ideas of local people about CCPP vaccine; now that the mission report is prepared, it is up to the sub-committec to set suitable resolutions.

Dr. Salemi appreciated the process as a good start and stressed on the technical improvements within the production. He stated that the recommendations of the working group are clear, and MADERA, considering the recommendations, would firstly hire an expert consultant, and train the staff in a recognized CCPP vaccine producing institute.

MADERA asserted the desire to send some samples to any European lab to be examined, and requested if FAO could help in this respect. It was suggested that the samples be sent to a lab in France.

DCA suggested that MADERA should be complemented with their initiative. MADERA would better go on then to stop. With regards to testing the efficacy of CCPP, the available ways should be used. Conducting a field trial was stressed upon, to check the field results.

MADERA requested if any agency could provide them with a list of Dari or Pushtu books to be used as reference by the clinic staff. MADERA tends to promote the production of not only CCPP but also other vaccines, i.e. Agalactia.

\section{General veterinary update by agencies}

\section{VETERINARY MEDICINE STORE:}

DCA, as reported in the last meeting, has opened a medicine dispensary store in Ghazni for veterinary field staff of NGOs in the region. The price scale, though not still clear, will be at least $10 \%$ lower than market prices in Peshawar. Agencies are asked to submit lists of their veterinary field staff in the region.

DCA, in response to a question, said that the store will have the basic and most needed medicine in stock for distribution. Part of the medicine is Pakistani, while products of international companies have also been procured. Responding to more questions, DCA said that before planning for extension of the programme to other provinces, the result of the venture in Ghazni will be considered. DCA provides the initial support for the establishment: the store will be self supporting then in the future.

FAO suggested that DCA should prepare a list of the available medicine in the store, and to send the Pushtu version of the list to VFUs in the region. DCA noted the suggestion.

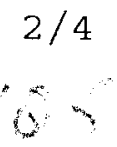


DCA plans to start the new course of paravet training in Charikar. The course will probably begin in September or October, given the completion of arrangements. Interested agencies were asked to nominate candidates for the course.

FAO will nominate 10 persons. FAO's concern was that more people in Paktia, Khost, etc need to be trained as paravets, while this seem not practical due to some reasons, such as the long distance to Charikar, not knowing Dari, etc.. As it was disclosed by DCA that training will be carried out in both Dari and Pushtu languages, FAO confirmed that some 10 persons will be nominated for the course, mostly from south castern provinces.

\section{DCA'S PROPOSALS:} The meeting was briefed on DCA's proposals for future activities. Some proposals have
been submitted to EU and FAO.

DCA has submitted a proposal for veterinary field work and paravet training to EU. This proposal, awaiting approval under DG- $1^{1}$ budget line of EU, covers provision of complete package of veterinary services for DCA's three main target provinces in the western Afghanistan, i.e. Herat, Ghor and Badghis.

DCA looks forward to EU's allocation of money for a big vaccination proposal that has been approved under DG- $8^{2}$ budget line. The proposal, covering 1 million ECHOs $(1.2$ million dollars) per annum, will support two year vaccination programme. The proposal is being

\section{VACCINATION CAMPAIGN:}

COAR has started a vaccination campaign in Logar, Wardak and Ghazni on 1st May, and will continue to the end of July. 40,000 animals, including cattle and poultry, are targeted to be vaccinated. According to work progress report, 20,000 animals have been vaccinated in
Logar in one month.

CoAR, as well, plans to conduct a Ectoparasite Campaign in Scptember. The programme will include spraying stables in the provinces.

\section{Any other business}

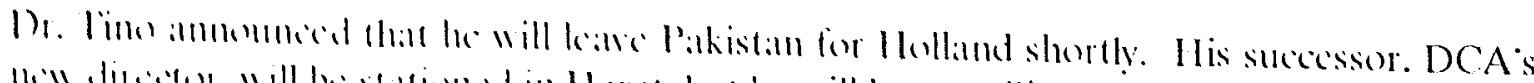

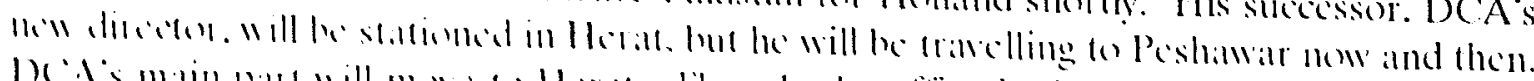

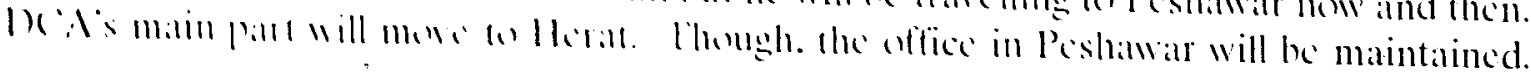

The chairman. on behalf the sub-committec thanked Dr. Tino for his good service for Afghanistan and his actice participation in the Veterinary Sub-committee, and wished him more sucess.

1 DG-1 is the budget line of European Union that has a refugee return and integration mandate.

DG-8 is the budget line of European Union that has a food 'supply mandate. 
ACBAR heartily appreciates Dr. Tino Hennecken's invaluable service, and, thanking him for his attentive participation in and cooperation with the Veterinary Sub-committee, wishes him every good luck for the future.

FAO, adversely concerned on duplication of activities and unfair provision of services, raised a point and said that the person in-charge of CoAR clinics in Wardak is a BVW, while many paravets, trained by either DCA or other agencies, look for jobs. COAR had promised to stop selling medicine on subsidized prices because of funding problems, but still continue giving subsidy on medicine sale.

$\mathrm{COAR}$, in response, claritied that no subsidy is given on medicine sale, while agro chemicals are sold on $15 \%$ subsidy. CoAR doubted the BVW being in-charge of CoAR's clinic, but stated that they will investigate the matter.

FAO stressed on formation of field based veterinarians associations to encourage more support for veterinary and ensure additional funds. Dr. Mehraban explained that if veterinarians share funds and jointly undertake programmes, such as DCA's store in Ghazni, a highly favorable outcome is expectable. FAO will extend possible support to such associations. In the past, some shop-keepers were supported to sell veterinary medicine, but the problem of non-standard medicine emerged then.

It was decided that, in the next meeting, Dr. S. Tahir, MADERA, will have a presentation on MADERA's activities in the field of veterinary.

NEXT MEETING: THE NEXT VETERINARY SUB-COMMITTEE MEETING WILL BE HELD ON 25 JUNE 1996 AT 9:00 A.M. IN ACBAR CONFERENCE ROOM.
Chairman:
Dr. M. A. Salemi
Minutes by:
A. Jawed Ludin

Participants:

$\begin{array}{lll}\text { - } & \text { Dr. Mehraban } & \text { FAO } \\ \text { - } & \text { Dr. A. Osmani } & \text { FAO } \\ \text { - } & \text { B. E. C. Schreuder } & \text { DCA, Holland } \\ \text { - } & \text { Dr. Tino Hennecken } & \text { DCA } \\ \text { - } & \text { Dr. Samsoor } & \text { DCA } \\ \text { - } & \text { Dr. Zimeray } & \text { PRB } \\ \text { - } & \text { Safi } & \text { ARDA } \\ \text { - } & \text { Dr. Ghulam Saced } & \text { CoAR } \\ \text { - } & \text { Dr. A. Ghafoor } & \text { GAF } \\ \text { - } & \text { Dr. M. S. Tahir } & \text { MADERA }\end{array}$

Absent agcncics:

ADA, Atghanaid, AWRC, BBC, EU, NPO/RRAA, RAFA, UNOPS 


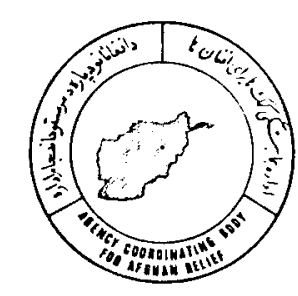

\title{
Veterinary Sub-Committee Meeting
}

\author{
Held on Thursday 25 July 1996
}

\section{Attention 4 questionnaire is attached for some of the sib committe niembers, Relevani ageneles are starred in the list of absent ageneies.}

I. Approval of the agenda and minutes of the last meeting

Agenda: $\quad$ Several points were raised by the floor to be discussed under item IV, General veterinary update, of the agenda. The points were noted by chairman.

Minutes: CoAR made some corrections. The term ECHO in the fifth paragraph, page 3, should read ECU, European Union's currency.

The sixth paragraph, page 3 , under vaccination campaign report by CoAR should read: "40,000 animals, including cattle, sheep, goats and poultry, are targeted to be vaccinated. According to work progress report, 20,000 animals have been vaccinated in Logar, Wardak and Ghazni provinces in one month.

II. $\quad$ Announcements

Some of the announcements made were suggested to be discussed under item IV, General Veterinary Update.

III. Activity presentation, by MADERA

Copies of MADERA's presentation were circulated to the participants. The presentation is attached with the minutes for the absent agencies who did not receive the papers.

A lengthy discussion on improvement of veterinary in Afghanistan followed. MADERA's new programme. straw treatment programme, was particularly discussed and appreciated by some agencies. It was suggested that, for the next meeting after the members study MADERA's presentation, they can address their questions to MADERA.

\section{General veterinary update, by agencies}

\section{NEW DISEASE IN SAYEDABAD}

CoAR reported that some symptoms discovered in Sayedabad district, Wardak, are corresponding to existence of Anaplasmosis. Based on reports, it is prevailing in more than $40 \%$ of cow and calf population. It was said to be an approximate diagnosis made by Dr. Ghulam Saeed after scrutinizing the symptoms. 
The floor suggested that CoAR, to accomplish full diagnosis, can provide a slide and take it to GAF's lab in Khost for cxamination.

\section{NEW VACCINES IN KABUL}

GAF reported that their monitor has seen some type of FMD vaccine and Tyloject medicine available in Kabul medicine markets. The vaccines keep no clear label as to indicate where they have been produced. A matter of bigger concern is the storage of the vaccine as it requires a certain and fixed temperature, while they are kept in the normal weather in medicine cupboards.

\section{UPDATE ON RABIES VACCINATION}

After the successful completion of Rabies vaccination campaign in Mazar-i-Sharif, whereby about 80,000 dogs were vaccinated, FAO started a similar campaign in the Eastern Zone provinecs, Nangarhar. Laghman and Kunar. This was a joint venture by FAO, UNICEF, WHO. MADERA and Health Department of Nangarhar Shura. The campaign was satisfactorily carried out in all districts of the three provinecs; although, the last part of the campaign, i.c. cradication of stray dogs, is still left. FAO is not involved in this part. Government authorities as well as WFP have been contacted to take over this responsibility.

Quite recently, FAO together with UNICEF, WFP and WHO has started the Rabies vaccination campaign in Kabul. To cover this programme, a quantity of 50,000 doses vaceines that were left from the previous campaigns will be used. Further, 90,000 more doses of the vaccine have been ordered. FAO added that no death case has so far been reported from Rabies in Kabul.

FAO was requested to prepare reports on the various campaigns in order to provide records and thus to facilitate follow up efforts in the future.

\section{RINDERPEST IN KHOST}

Rinderpest was diagnosed in Khost. It was strongly believed to be imported from Pakistan, as the diagnostic studies indicated similarity between the cases in Khost and Rinderpest in Karachi. The problem was that Pakistan authorities paid little heed to this problem and did not admit prevalence of Rinderpest in Pakistan. This continued until last year when more than 40,000 cows died from Rinderpest.

In Khost, FAO has started Rinderpest vaccination campaign. 50,000 doses out of the available 100,000 doses vaccines were used. The campaign comprised of 40 persons that were very well equipped to reach all parts of the provinee with vaccination facilities.

\section{FAO MISSION TO SOUTHERN PROVINCES}

Dr. Mehraban, FAO, had recently returned from a mission to Zabul, Helmand, Urozgan and Kandahar. The veterinary services, as he witnessed in these provinces, were good but not enough. ADA reportedly had good activities in the region. FAO reported Gangerenous Mastitis, Agalactia, etc. as the visibly prevailing diseases in the region with little suitable treatment available.

\section{FAO'S POULTRY TRAINING PROGRAMME}

FAO has trained 30 women in poultry production in Helmand. A training programme for men in Helmand comprises of 100 men. FAO viewed that the women programme was very effective and envisaged no problem from the Taliban. The only problem of the trainees after completion of the course is that they are located in different places mostly far away from clinics and thus deprived of veterinary services. It could be suggested that loeal veterinary 
workers be trained fïrst.

Moreover, FAO has approved a quitc similar programme, poultry production, for a group comprising of 14 men and 16 women in Kabul. FAO will provide the trainees with eggs and poultry food, while incubator should be provided by themselves.

\section{CHARGING FOR VETERINARY SERVICES}

GAF reported that they have received a complain from Baraki district, Logar, regarding fee charging for veterinary services. CoAR reportedly charges no fee for the services and thus it has created a big confusion among people who pay money for the services to GAF.

CoAR refuted the allegation commenting that, except for examination, all other services are charged for.

\section{COAR'S COLD CHAIN PROGRAMME}

COAR has started a cold chain programme in Logar, Wardak and Ghazni. Necessary supplies, e.g. freezer, cold box, gas, etc. have been provided.

DCA's activity report is attached.

\section{Any other business}

ACBAR had circulated copies of FAO's questionnaire on VFU income to some of its members not funded by FAO. CoAR and DCA, who had received the questionnaire, reported to have some problems in provision of the information. The far and widely dispersed locations of clinics is one of the problems that would require hiring a monitor to travel to each clinic and help the paravets in filling out the questionnaire.

This issue will be further discussed in the next meeting.

** MADERA was requested to report their follow up on the recommendations of the CCPP vaccine production monitoring working group that accomplished a mission to Kunar in June.

*** MADERA reported that they will conduct a mission to Behsud I and Behsud II of Hazarajat areas. The purpose of the mission will mainly comprise of improving sheep breeding. MADERA, if possible, will report on the mission to the next meeting.

NEXT MEETING: THE NEXT MEETING OF THE VETERINARY SUB-COMMITTEE WILL BE HELD ON THURSDAY 22 AUGUST 1996, AT 9:00 AM IN ACBAR.

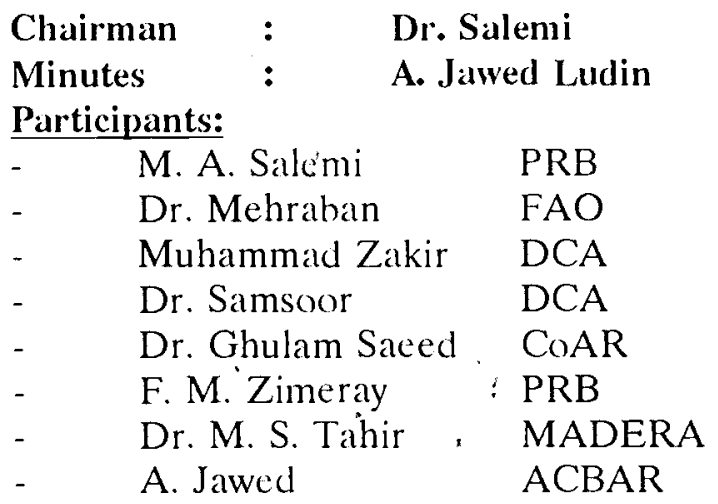


Absent:

Afghanaid*, ADA, ADF, AFRANE*, ARDA, AWRC*, EU*, NPO/RRAA*, RAFA*, UNOPS* and Solidarites*.

*. The starred agencies are cordially requested to fill out the following questionnaire and send it back to Ahmad Jawed Ludin, at ACBAR Programme Department not later than 15 August 1996. Your urgent feed back will be appreciated.

Please cut this portion and send.

$\mathrm{X}$ $\mathrm{X}$

AgencyName:

Are you working/interested to work in veterinary sector? Yes () No ()

Have you previousely participated in ACBAR Veterinary Sub-committee meetings? Yes () No () if no WHY?

Have you been receiving properly the minutes and agenda for the meetings? Yes () No ()

Do you approve the need for coordination of veterinary activities? Yes () No () if no WHAT IS THE REASON?

In your view, what are the effective points with current veterinary sub-committee?

1

2.

3

In your view, what are the in-effective and weak points with the sub-committee?

1.

2

3

If provided properly with minutes and agenda, are you interested to regularly participate in the meetings of the sub-committee? Yes () No () if No WHY?

If Yes, please nominate a person within your organization who will attend the meetings:

Name:

Your name:

Signature:
Title:

Title:

Date: 


\section{Veterinaity GUh-CommitTeE Meetive: Held on Thursday 22 August 1996}

Since the chairman was out of town, and the deputy chairman, Dr. Tahir, arrived late from Jalalabad, the floor appointed Dr. Samsoor, DCA, to chair the meeting.

I. Approval of the agenda and minutes of the last meeting

Both the agenda and minutes were approved in absence of any comments.

11. Announcements

MADERA sadly announced that Mr Khoshal Habib, MADERA Regional Officer in Kunar, was tragically shot dead in Jalalabad a few days back by some armed thieves.

The floor expressed sorrow and condolence over the issue.

COAR was requested, in the last meeting, to provide a slide from the Anaplasmosis symptoms in Wardak and take it to GAF diagnostic lab in Khost. CoAR, accordingly, announced that Dr Bashir from GAF has already provided a slide but the result is still to be announced. 10 cattle reportedly died from Anaplasmosis in one village. This was reported by Dr Ghulam Saced, CoAR, who visited Ghazni and Wardak last week.

In response to FAO's query regarding the postmortem inspection of the died cattle, CoAR said that only one report existed on Splenomegaly in a dead cattle.

III. Activity presentation, by MADERA

The activity presentation was circulated in the last meeting. PRB asked some questions that were responded by Dr Tahir. MADERA.

Dr Emal, from MADERA Laghman, briefed the floor on MADERA's Straw Treatment programme. This programme is aimed at provision of tasty and nutrient food for animals. For this purpose, whe at straw is used, while, in the next step, MADERA will experience rice straw.

Dr Emal explained that $100 \mathrm{kgs}$ of wheat straw are thoroughly mixed with $4 \mathrm{~kg}$ Urea dissolved in 20 to 40 liters of water. It is then covered by plastic or mud and kept for some time. The outcome will make a more tasty and fortified food for animals.

\section{$\eta / \beta_{3}$}


In response to a relevant question from RAFA, FAO cnlightened that fungus affection of the straw treatment will be more probable only incase that too much water is used. Whereas MADERA's method is perfect. "The straw treatment increases digestibility and intake capacity of animal, and it is important to note that if a farmer cannot afford providing extra straw to feed his animal, the value of the treatment will be lost.". added FAO.

\section{General veterinary update}

\section{DCA'S PARAVET TRAINING CENTER}

DCA's training eenter is shifted from Peshawar to Charikar. The new course of training will begin on 1st September 1996. The building for the training eenter is under construction and will be completed on 15 September. Until then, the training will be centered in a rental house. Accommodation is already provided for the trainees in Charikar, and NGOs can start deploying their nominees to the center.

DCA will set up a clinic in Charikar for training purposes. This clinic will have to provide tree medicine and treatment.

FAO said that PRB has a clinic in Charikar, and suggested that DCA consult PRB to avoid the misunderstanding that the provision of free medicine and treatment might cause. It was further suggested that DCA could take the trainees to PRB's clinic to see and get familiarized also with the charging policy.

DCA, accordingly, said that contacts have already becn made with PRB. PRB was also requested to submit the elinic to DCA but the request was turned down with the reason that the clinic was funded by FAO.

\section{FAO'S MEETING WITH AGRICULTURE MINISTER}

Mr Barker, FAO, reported that, last week, he was in Kabul, where he met wịth Dr. Sikandar, the newly appointed Agriculture Minister. FAO, in the meeting, introduced its policy which was approved by the minister. Some further important points, ie the charging policy for vaccination, quality of medicine, etc were discussed.

\section{UPDATE ON RABIES AND RINDERPEST}

Rabics vaccination campaign is continuing in Kabul, with around 10,000 dogs vaccinated. The campaign will be moved to Khost after completion in Kabul.

Rinderpest vaccination is going on in Khost. FAO has hired an Iranian Rinderpest expert.

FAO also has appointed three regional coordinators for the eastern, western and southern regions. Their job is to maintain surveillance on veterinary problems in the regions.

\section{MALAISES PLAKS}

FAO reported that they have ordered 50,000 Malaises Plak to be used in Jaji Maydan, Ghazni and Kabul. Last year, some demonstrations were made in Jaji Maydan and Ghazni which proved of good results. It will be sold through VFUs. The recommended price per $\mathrm{kg}$ is $\operatorname{Rs}^{\circ} 10$. 


\section{CoAR'S ACTIVITIES}

CoAR has distributed 200 ewes to widows in Zena Khan of Ghazni, and Sayedabad of Wardak.

The three months vaccination campaign by CoAR, which started on 1st May 1996, is completed. A total number of 58,000 animals have been vaccinated.

\section{VISIT TO HOECHEST}

MADERA reported that they will have a mission to Kabul shortly. Visiting Hoechest Kabul will be included in the mission. MADERA viewed that the agencies working in veterinary can approach Hoechest with orders for medicine production. "This will, at the same time, be a good step in support of national industry.", said MADERA.

\section{GAF'S POULTRY MANAGEMENT PROGRAMME}

GAF runs a Poultry Management Programme in Herat which is funded by UNOPS. Under this programme. 150 women are trained in 50 villages.

\section{V. $\quad$ Any other business}

MADERA's mission to Behsud I and Behsud II of Hazarajat, as announced in the last meeting, could not take place this month. MADERA will shortly resume the said mission.

\section{NEXT MEETING: THE NEXT MEETING OF VETERINARY SUB-COMMITTEE WILL BE HELD AT 9:00 AM ON THURSDAY 19 SEPTEMBER 1996 IN ACBAR CONFERENCE ROOM.}

$\begin{array}{lll}\text { Chaired by } & : & \text { Dr Samsoor, DCA } \\ \text { Minutes by } & : & \text { Ahmad Jawed, ACBAR }\end{array}$

\section{Participants:}

$\begin{array}{lll}- & \text { M A Rashid } & \text { RAFA } \\ \text { - } & \text { M Yosef Khashia } & \text { AOR, Mazar-i-Sharif } \\ \text { - } & \text { M Zakir } & \text { DCA } \\ \text { - } & \text { Dr Samsoor } & \text { DCA } \\ \text { - } & \text { Dr Zimeray } & \text { PRB } \\ \text { - } & \text { Dr Ghulam Saced } & \text { CoAR } \\ \text { - } & \text { Dr A Ghafoor } & \text { GAF } \\ - & \text { T J Barker } & \text { FAO } \\ - & \text { Dr M S Tahir } & \text { MADERA } \\ \text { - } & \text { Dr M J Emal } & \text { MADERA } \\ \text { - } & \text { A Jawed Ludin } & \text { ACBAR }\end{array}$

Absent agencies:

Afghanaid, ADA, ADF, AFRANE, ARDA, AWRC, EU, UNOPS

$$
\begin{aligned}
& 3 / 3 \\
& 1 / 5
\end{aligned}
$$




\section{Veterinary Sub-Committee Meeting \\ Ihola on Tharsilay 19 September 1996;}

The meeting was poorly participated. The absent agencies were commented on for being reluctant to participate in the meetings and strengthen coordination.

THE ABSENT AGENCIES (LISTED AT THE END) ARE REQUESTED TO EITHER DELEGATE THEIR REPRESENTATIVES TO THE MEETINGS OR INFORM ACBAR IN ADVANCE OF THEIR ABSENCE. THIS WILL NOT ONLY REGULARIZE ORGANIZING THE MEETINGS AND FACILITATE COORDINATION BUT WILL ALSO AVOID WASTAGE OF PAPERS AND OTHER MATERIALS PROVIDED FOR PARTICIPANTS BEFORE THE MEETINGS.

I. Approval of the agenda

Item \# 3 was postponed for the next meeting since Mr Haroon from GAF was not able to attend the mecting due to his involvement inside the country.

Item \# 4 was cancelled.

II. Comments on minutes of the last meeting

The expression "Molasses Plocks" was misspelled in the last paragraph, page 2, DCA made the correction.

PRB, commenting on paragraph 5, page 2, said that one of the reasons that PRB's clinic in Charikar was not committed to DCA is that PRB gets multiple use out of the clinic which is vital for its activities in the region. The clinic, for example, is used as storage base for supplies to the region.

III. Announcements

MADERA announced that they conducted a preliminary survey on need assessment in Hazarajat from 24 to 30 August 1996. The survey covered Behsud I and Behsud II, and included assessment of veterinary services, besides other sectors. A detailed two months survey of the region may follow in the near future. Please read the details under item vi "General veterinary update".

VI. General veterinary update, by agencies

\section{MADERA'S SURVEY}

MADERA, from their survey in Hazarajat, reported that livestock was common and extensive, but livestock nutrition had a poor situation. Bad conditions of stables was another problem witnessed. The common animal diseases in the region were reported to be Enterotoxemia, Anthrax, Brucellose, Mastitis and Blackleg (Black quarter). 
MADERA, as for present, plans to appoint and fix some paravets in the region and, further, some vaccines will be deployed shortly.

\section{CALAMITY IN POULTRY}

DCA presented a report they had received from Herat regarding a continuous high mortality in poultry in that province. The report denoted that, recently, some FAO supported agencies in Herat imported hens and eggs from Pakistan but, unfortunately, the quarantine regulations were not properly applied and health certificates were not obtained. As the result, a high mortality rate among, specially, the young chicks is being reported. The primary check up, autopsy and other researches contradicted the Newcastle outbreak, while symptoms support possibility of Infectious Bronchitis and Gumboro. Report added that DCA has no vaccine in store in Herat. ACBAR Veterinary Sub-committee was, thus, requested to react accordingly.

\section{VETERINARY PROGRAMME OF MINE DETECTION DOG CENTER (MDC)}

MDC's veterinary programme is limited to providing services for the dogs they use for mine clearance purposes. The veterinary programme is mainly prevention oriented and include less treatment services. The reason is that usually a deminer dog, after getting a major treatment, stays unreliable for mine detecting exercises. Each demining team, within MDC, includes a paravet and each sub-office is employing a veterinarian. MDC has around 90 dogs.

VII. Any other business

* Neither CoAR nor GAF made any update on Anaplasmosis situation in Wardak.

FAO had sent a hand out of information on Ammonia Treatment of Straw to the subcommittee, which was photo copied and circulated to the members by ACBAR. The hand out is attached for some of the absent agencies.

NEXT MEETING: THE NEXT MEETING OF THE SUB-COMMITTEE WILL BE HELD ON THURSDAY 24 OCTOBER 1996 AT 9:00 AM IN ACBAR CONFERENCE ROOM.
Chaired by :
Dr M S Tahir, MADERA
Minutes by
A Jawed Ludin, ACBAR

Participants:

\begin{tabular}{lll} 
- & Dr Samsoor & DCA \\
- & Mohd Akbar Baburi & CoAR \\
- & Dr Mir Ahmad & GAF \\
- & Dr Ahmad Kazcm & PRB \\
- & Dr M S Tahir & MDC \\
- & Ahmad Jawed & MADERA \\
\hline
\end{tabular}

Absent agencies:

Afghanaid, ADA, ADF, AFRANE, ARDA, AWRC, EU, FAO, RAFA, UNOPS

$2 / 2$

117 


\section{ACBAR

\section{VETERINARY SUB-COMMITTEE MEETING \\ 24 October 1996}

Due to absence of the chairman, Dr Tahir, MADERA, presided over the meeting.

\section{Approval of the agenda}

Item \# iv, Presentation on Veterinary Associations - by Mr Haroon - GAF, was postponed, for the second time, to the next meeting as Mr Haroon was reportedly in Mazar and could not participate in the meeting.

The agenda was approved then.

2. Comments on minutes of the last meeting

The first paragraph, last page of the minutes, should read: "MADERA, as for present, plans to appoint and fix some paravets in the region and, further, some vaccines might be deployed shortly provided that conditions are ok.

\section{Announcements}

No announcements.

4. Review on vaccination prices

This item was proposed by COAR. Since COAR did not participate in the meeting, proper discussions could not take place. Nevertheless, some important points were raised respectively.

FAO said that, under FAO policy, the minimum charges for vaccination services are fixed for different animals, ie, cattle - Afs 100, sheep/goat/etc - Afs 50, and poultry - Afs 20. The veterinarians can charge more only in case that livestock owners are willing to pay. In response to MADERA's suggestion regarding free vaccination services, FAo added that now the public of Afghanistan are aware of the importance and value of vaccine so people will not stop paying for vaccine. This will certainly help a self-sustaining veterinary sector.

\section{$1 / 3$}


COAR was requested to attend the next meeting of the subcommittee and share with the meeting if there is any special reason for reviewing the vaccination charging policy.

5. Report on NPPP Conference, September 1996 Islamabad, by FAO

FAO held the annual conference of its National Professional Project Personnel (NPPP) in Islamabad from 22 to 25 of September. 15 NPPPs participated in the conference. Mainly, technical issues and problems were focused on for discussion. Reports from all FAO IPs from all the five FAO operational regions were reviewed. Credit was allowed to the IPs who proved to be working constructively.

Other issues discussed in the conference were: plans for future, deceit in vaccine/medicine, animal nutrition, animal diseases in different seasons - based on researches and experiences recorded by FAO field centers, refresher and inservice training, and probable establishment of regional diagnostic centers.

Some of the present agencies requested FAO to provide them with copies of the research data by FAO regional centers. FAO promised to make the papers available as soon as they are sorted out.

MADERA said that FAO should have invited, at least some of, the most involved agencies to the NPPP conference. As MADERA's veterinary activities are very much linked with FAO, MADERA would also like to be involved in any event of this sort.

\section{General veterinary update, by agencies}

DCA'S TRAINING PROGRAMME IN HERAT

DCA announced that their paravet training course will start on 1 December in Herat. Agencies can nominate trainees to the programme before the mentioned date.

DCA reported that their paravet training course in charikar has been temporarily shifted to kabul after the recent military and political changes in the region. The course is normally functioning.

BVW TRAINING PROGRAMME IN BADAKHSHAN .

$\mathrm{PRB}$ reported that Afghanaid is running a BVW training programme in three districts of Badakhshan and claim that the programme is funded by FAO. PRB, showing concern over 
duplication of activities, asked FAO for clarification as PRB was implementing FAO's BWV training programme in that province.

FAO clarified that they are funding no BVW training for Afghanaid in Badakhshan.

It was suggested that Afghanaid be invited to the next meeting to report on their activities and, particularly, clarify the said issue.

\section{MONTHLY AND ANNUAL REPORTS OF IPS}

FAO complained about the careless reporting of some of their IPs. The implementing agencies report on their activities every month and provide an annual report at the end of every year. However, most of the times summations of the figures from the 12 monthly reports are far different than the annual reports. FAO requested the agencies to take more time and care while providing the reports. This problem is very critical because the figures are important for the database that FAO is currently operating.

\section{AGRICULTURE AND FOOD PRODUCTION SEMINAR BY FAO}

PRB reported that FAO is conducting a two day seminar on agriculture and food production on 30-31 october 1996 in Peshawar. It is a matter of deep concern that no implication of veterinary has been made in the contents of the seminar. This is an obvious fact that veterinary is the best and most successful programme being implemented in Afghanistan.

ACBAR was requested to write a letter to FAO Agriculture office and, notifying the issue, ask FAO for a solid conclusion.

\section{Any other business}

As Dr M A Salemi, Chairman of the Veterinary sub-committee, has been on his new assignment inside Afghanistan for the last few months, and based on contexts he may not be able to appear for the next meetings in future, it was decide that his position be suspended. After some discussions, Dr M Sabir Tahir, MADERA Livestock Coordinator and the current Deputy Chairman of the Sub-committee, was elected as Acting Chairman of the Veterinary sub-committee to the end of this year.

Election of new chairperson for the sub-committee will take place in January 1997. Nomination of candidates for the position could be received before January.

* PRB reported that they plan to start Rinderpest prevention/vaccination programme in the northern provinces. PRB requested if one of FAO's Rinderpest expert be invited for a meeting, whereby many of the relevant questions can be discussed. "FAO, noted the point and hoped that the expert will be available in the near future. 
NEXT MEETING: THE NEXT VETERINARY SUB-COMMITTEE MEETING WILL BE HELD ON THURSDAY 21 NOVEMBER 1996 AT 9:00 AM IN ACBAR CONFERENCE ROOM.

Chairman : Dr M Sabir Tahir, MADERA

Minutes : A Jawed Ludin, ACBAR

Participants:

- Dr A A Nasseri, Deputy Manager, FAO Islamabad

- Dr M S Tahir, Livestock Coordinator, MADERA Jalalabad

- Dr F M Zimeray, Advisor, PRB Peshawar

- Dr Nazir A Sherzai, Monitor, PRB Peshawar

- Eng Esmat, Planning Director, ADA Peshawar

- Dr Samsoor, Extension/Monitoring Coordinator, DCA Peshawar

- S Safi, Coordinator, ADF Peshawar

- Dr Ahmadi, Field Veterinarian, MDC Peshawar

- Dr Mir Ahmad, ?, GAF Peshawar

- A Jawed Ludin, Information officer, ACBAR Peshawar

Absent agencies:

Afghanaid, AFRANE, ARDA, AWRC, EU, RAFA, UNOPS, OXFAM

Apologies:

COAR 


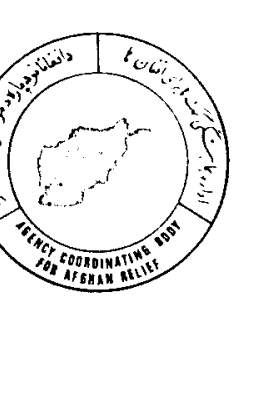

ACBAR TIS!3.

A genCY COORDINATING B ODY FOR A FGHAN RELIEF

\section{VETERINARY SUB-COMMITTEE MEETING \\ 28 November 1996}

1. $\quad$ Approval of the agenda

The representative of Afghanaid, who had to leave early for another meeting, suggested that the item 4 of the agenda, "Briefing on Afghanaid activities in Badakhshan", be discussed before the "Presentation on Veterinary Associations".

\section{Minutes of the last meeting}

COAR had some concerns over the charging for vaccination. Some relevant questions from COAR were responded by FAO. FAO said that charges for vaccination have two parts, cost of vaccine and fee for vaccination. Under FAO's policy, the cost of vaccine is free, but their is a minimum fixed fee for vaccination while veterinarians have the chance to charge more than the fixed prices if the beneficiaries agree.

The second sentence under MONTHLY AND ANNUAL REPORTS OF IPS should read "The implementing agencies report on their monthly activities every two months and provide an annual report and CSA at the end of every year."

\section{Briefing on Afghanaid activities in Badakhshan}

Mr J Nurmohamed, Project Director Afghanaid, represented his agency and kindly accepted the request to put some lights on their activities in Badakhshan. As reported in the last meeting, PRB had big concerns over Afghanaid's BVW training programme in Badakhshan which was believed to be duplication of PRB's programme.

Afghanaid, first, apologized for no proper representation in the sub-committee meetings. This was said to be because of limited staff in Peshawar.

Referring to PRB's concern, Afghanaid said that this issue has already been resolved. They had a meeting with PRB on 13 November, where this issue was also discussed and Afghanaid accepted to stop its programme in case it is not really needed. Any further discussions in this regard could take place directly between PRB and Afghanaid.

In a briefing on their activities, Afghanaid stated that they have changed their approach towards delivering. veterinary assistance. Afghanaid with collaboration with some other partners will be working on livestock improvement in other new ways. Before delivering any assistance, the different impacts should be scrutinized. For example, no vaccination should take place without prior understanding of the real need for that and ensuring no bad effects on environment; one of the bad effects could be increase in number of animals with no increase in capacity of pastures. 
Afghanaid has stopped vaccination to check the impacts on pastures. Specially, the Shewa plains are going towards eradication. If not controlled, Shewa plains will be finished in 20 years.

Afghanaid added that there is a need for coordination of activities, and a joint work to encourage the commanders to stop selling lands of Shewa plains to farmers. This is a severe problem, which could be stopped only if there is a stable government.

FAO also reported a similar problem in Herat where pastures were used for cultivation.

\section{Presentation on Veterinary Associations}

\section{(By M Haroon, Coordinator UVSA - Umbrella For Coordination of Veterinary Services Associations)}

M Haroon distributed copies of the VSA Guidelines to the participants. Mr Haroon, besides, briefed the floor on VSA and its establishment. VSA, basically a profitable NGO, has been an initiative of FAO. Initially funded by FAO, the association is established with the aim to make available cheaper and good quality medicine for veterinarians, assistant veterinarians and paravets in Afghanistan. VSA is based in GAF office, Peshawar.

FAO said that they will continue to support VSAs till they stand on their own feet.

Mr Haroon, in response to the questions from the floor, agreed that the guidelines are not complete and need modifications. Any constructive comments from the agencies will be highly appreciated. Agencies can contact him in case they suggest any modifications. He added that VSA will include conducting seminars and technical conferences in Afghanistan in its action plan once it is strong enough to afford it. VSA will also consider establishing local labs for some $\chi$ limited medicine production. As soon as the situation allows, VSA will establish its central association in Kabul.

In a prolonged open session that followed Mr Haroon's presentation, several other relevant questions were raised, which were discussed in details.

The details on the so far established regional associations are attached.

\section{General veterinary update}

\section{DUPLICATION OF ACTIVITY IN NURISTAN}

ADF said that, based on reports of their monitors from ADF's veterinary clinic in Nangarage Nuristan, MADERA is also running a veterinary clinic in the same village. These two clinics are too much for the area mentioned. ADF wanted that this important issue should be discussed and either of the agencies should move from that area.

MADERA disclosed that since MADERA has a long history of activity in the said area and they are working on several other projects there, MADERA's clinic would rather like to stay.

FAO suggested that MADERA and ADF set together, with FAO mediating, to resolve this problem. The outcome will be reported to the next meetings.

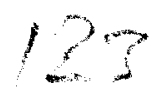




\section{PRB'S CLINIC CONSTRUCTION}

PRB has just completed construction of a building for its veterinary clinic in Faizabad. The clinic is, reportedly, very well mobilized with provincial level veterinary services.

\section{GAF UPDATE ON RINDERPEST}

FAO's Rinderpest vaccination campaign started in September in Khost. In October, they were able to implement the campaign in 10 districts. GAF added that they will start Rinderpest vaccination in Logar and Ghazni shortly.

\section{ETV VACCINATION BY MADERA}

MADERA implemented an ETV vaccination campaign in Kunar and Nuristan from 21 October to 1 November 1996. Approximately, 118000 doses of the said vaccine were used.

\section{NDV AND MOLASIS NEEDED BY GAF}

GAF reported that while visiting their clinics in different regions, their field veterinarians expressed their need for more NDV vaccine as well as Molasis. Molasis has reportedly had incredibly good effect on animal nutrition. GAF requested if FAO provide them more NDV vaccine and Molasis.

There was a view point suggested by a number of agencies, ie PRB, GAF and MADERA that the technology of Molasis production would be very positive step if shifted inside Afghanistan. While the raw materials are easy to procure in Afghanistan, the machinery will also be reasonable to buy from outside. It was suggested that FAO should do something in this regard.

Responding to the above questions, FAO said that they will provide NDV for GAF. Molasis will also be provided but probably not for those areas where other alternatives, eg, good pastures, exist. Regarding the technology of Molasis production inside Afghanistan, FAO would like it. NGOs can first check the possibilities of this venture as well as availability of raw materials; FAO may extend possible assistance as part of its continuous support to such activities.

\section{MADERA'S STRAW TREATMENT}

MADERA reported that following their wheat straw treatment experiences, now they have launched six experiments with rice straw in Laghman. MADERA hoped that they will get good results from their experiments.

\section{6. $\quad$ Any other business}

The last Veterinary Sub-committee meeting of the year 1996 will take place on Thursday 19 December 1996 at 9:00 in ACBAR conference room. This will be a special meeting and the subcommittee will make an overall overview of its work in 1996.

Besides, all member agencies of the sub-committee will overview their major activities in the past year. To this end, the members of the sub-committee are requested to prepare a brief presentation and contact ACBAR at least one week before the meeting, in order for them to be included in the agenda for the meeting.

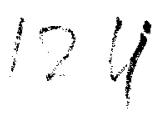


NEXT MEETING: SEE UNDER ANY OTHER BUSINESS.

$\begin{array}{lll}\text { Chairman } & : & \text { Dr M Sabir Tahir, MADERA } \\ \text { Minutes } & : & \text { A Jawed Ludin, ACBAR }\end{array}$

The participants:

Dr M S Tahir, Livestock Coordinator, MADERA Jalalabad

Dr A Ghafoor, Director, GAF Peshawar

Dr A A Nasseri, Deputy Manager, FAO Islamabad

Dr Nazir A Sherzai, Monitor, PRB Peshawar

Dr Ahmadi, Field Veterinarian, MDC Peshawar

$M$ Haroon, Coordinator, UVSA Peshawar

Dr G Saeed, Veterinary In-charge, CoAR Peshawar

Safi, Coordinator, ADF Peshawar

J Nurmohamed, Project Director, Afghanaid Peshawar

Eng Esmat, Planning Director, ADA Peshawar

Dr Zimeray, Advisor, PRB Peshawar

A Jawed Ludin, Information Officer, ACBAR Peshawar

Absent:

DCA

RAFA

Always absent agencies:

AFRANE

ARDA

AWRC

EU

OXFAM

UNOPS 
veterinary extension services are going on in Herat, Ghor, Badghis, etc. A store for veterinary medicine has been set up in Ghazni city, to make available cheaper and good medicine for the veterinary staff of NGOs in the field. Further, DCA has continued to produce publications for awareness.

DCA distributed a booklet, "Calfrearing", to the participants.

MDC's veterinary activities are restricted to taking care of their deminer dogs. MDC, currently, has 93 active adult dogs. Dogs are provided with complete veterinary services, ie deworming, etc., every six months.

Dr Salemi, Coordinator of TCP/FAO (Technical Cooperation Project), reported on Rinderpest Project in Afghanistan. This project was started in August 1996 by FAO, conducting vaccination in Khost. TCP/FAO has accomplished surveys in many areas of Afghanistan. A table of details on Rinderpest vaccination in Khost is attached.

5. $\quad$ Activity update

Most of the agencies included their activity update in the previous item (presentation on their activities in 1996).

FAO reported that, three weeks back, a lab was established in Dand district, Kandahar. It was also reported that FAO will start Rabies vaccination programme in Herat shortly. FAO plans to start publishing a newsletter for its veterinary services in the near future. Cooperation of other agencies will be appreciated.

\section{6. $\quad$ Any other business}

FAO protested about some rumors in Herat, which were reportedly instigated by DCA's regional office in Herat. The subject of the rumors (relating to submission of FAO's clinics in Herat and Farah to DCA) was believed to be very much important and official.

Refuting the allegations, DCA defended their regional office and said that the subject was not new. DCA assured FAO that their regional office was not involved at all in this issue.

MADERA was criticized for having not followed the recommendations of CCPP production monitoring group, that were set out after a monitoring mission to Kunar in June 1996. MADERA was supposed to, after application of the recommendations, arrange a follow up mission to Kunar before the end of the year. Now the year 1996 has gone, but no follow up efforts have been made by MADERA.

It was suggested that a Technical Publication Review Board be set up within the Veterinary Sub-committee. This suggestion was made after DCA reported that they are doing publications relating to veterinary services. The board will be responsible to review and approve publications of member agencies before they go for printing. This issue will be further discussed in the next meeting.

**** Dr Salemi raised a concern over the probable clash between medicine store of DCA and veterinary medicine supply programme under VSA. DCA, in this regard, said that both are new

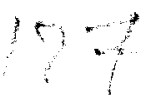


initiatives and should go on. The future would decide which one to continue, depending on the success achieved by either of the two programmes. FAO viewed that good competition could be useful. However, to avoid negative impacts, DCA and VSA can set together and avoid any possible duplication.

NEXT MEETING: THE NEXT VETERINARY SUB-COMMITTEE MEETING IS PLANNED TO BE HELD ON 30 JANUARY 1997 AT 9:00 AM IN ACBAR CONFERENCE ROOM.

Chaired by : Dr Salemi, TCP/FAO

Minutes by : Ahmad Jawed, ACBAR

The participants:

$\begin{array}{llll}\text { - } & \text { Dr M S Tahir } & \text { Livestock Coordinator } & \text { MADERA } \\ \text { - } & \text { Dr Ahmadi } & \text { Field Veterinarian } & \text { MDC } \\ \text { - } & \text { Dr M Kazem } & \text { Veterinary Coordinator } & \text { PRB } \\ \text { - } & \text { Dr Nazir Ahmad } & \text { Monitor, Takhar } & \text { PRB } \\ \text { - } & \text { Eng Esmat } & \text { Planning Director } & \text { ADA } \\ \text { - } & \text { Dr A Qadir Samsoor } & \text { Extension Coordinator } & \text { DCA } \\ \text { - } & \text { Mohd Seddeq } & \text { Representative } & \text { ADF } \\ - & \text { Dr A Nasseri } & \text { Deputy Programme Manager } & \text { FAO } \\ \text { - } & \text { M A Salemi } & \text { National Coordinator } & \text { TCP/FAO } \\ - & \text { Ahmad Jawed Ludin } & \text { Information Officer } & \text { ACBAR }\end{array}$

Absent agencies:

Afghanaid, AFRANE, AWRC, COAR, EU, GAF, OXFAM, RAFA and UNOPS.

Apologies:

Shah Mahmood Safi, ADF (ARDA) 


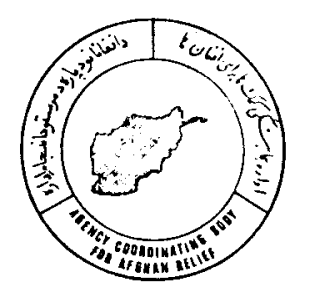

\section{A REVIEW ON VETERINARY SUB-COMMITTEE IN 1996}

The ACBAR Veterinary Sub-committee has been one of the successful coordination groups within the aid community. It has been able to effectively address issues of concern for coordinated activities. The sub-committee has enjoyed considerably good and attentive participation of the agencies which, though few in number, but have run extensive programmes in veterinary sector. This has probably been the reason why the sub-committee is successful.

The roles of chairpersons and deputy chairperson have been significant. Dr Nabi Hussaini from DCA. whose appointment, as chairman of the sub-committee, went some years back, headed the sub-committee up to March 1996, when he was no more able to continue with his involvement in the sub-committee. The sub-committee, with no doubt, owes much of its success to his contribution. Dr Mohammad Arif Salemi from PRB, who succeeded Dr Hussaini, contributed appreciable efforts to the sub-committee in his period of assignment, which was, though short, very effective. Unfortunately, after absence in three consecutive meetings, his position had to be suspended. Dr Mohammad Sabir Tahir from MADERA. who had been the deputy chairman of the sub-committee since 1995, was elected as acting chairman. He is currently leading the sub-committee.

Specifically, in the year 1996, the sub-committee has tackled some problems that could have been of big concern if not addressed.

The highlights of the sub-committee's work, in 1996, are listed, monthly sorted, as follow:

\section{January: (Chaired by Dr Tahir, MADERA)}

FAO reported on their decision of charging for sheeppox vaccine. The decisjon was said to be taken in light of the insufficient funds available for vaccination. A minimum price for 1 dose was Rs 0.6 . The money generated from the vaccine sale would be used to purchased
other vaccines.

Dr Samsoor, DCA, made a presentation on their extension services. The aim of the services was said to be enhancing communication and technical skills and providing awareness among the farmers. Charts, leaflets and booklets were used. According to reports, the extension massages, especially in colostrum feeding and Rabies preventive measures were well received by farmers.

February: (Chaired by Dr Tahir, MADERA)

ADA announced that they have taken the responsibility of 7 VFUs from DCA.

FAO was criticized for its charging policy for vaccination. DCA said that they have not been consulted by FAO. DCA added that shortage in fund should not lead to change in policy. MADERA, also criticizing the policy, stressed that such steps should be taken in consultation with other agencies.

FAO reasoned that the decision was taken based the policy of moving towards privatization. 
March: (Chaired by Dr Tahir, MADERA)

Dr M A Salemi, who was nominated by PRB, was elected as chairman, Veterinary Subcommittee.

MADERA circulated a handout on their CCPP vaccine production, which was followed by a briefing on this issue, by Dr Tahir.

MADERA's initiative was appreciated by the members. However, concerns were raised about the technical and safety standards of vaccine production. A working group was formed to:

a. Monitor the results of using the auto vaccine by visiting farmers and asking their opinion.

b. Check the laboratory conditions and procedures used.

The working group was made up by:
1. Dr Usmani, FAO
2. Dad Mohammad, ADF
3. Dr Anbergul, GAF
4. Dr Shafiq, MADERA
5. Dr Salemi, PRB

Dr Salemi and Dr Usmani would prepare a draft Terms of Reference for the working group.

A second presentation on DCA extension services was undertaken by Dr Samsoor, in which he explained the technical qualification of their extension workers.

A discussion on FAO vaccine sale policy was raised, in which some agencies strongly disagreed with the policy.

\section{April: (Chaired by Dr Salemi, PRB)}

"Terms of Reference for CCPP Vaccine Production" and "Update on Sheeppox-Vaccine Sale Policy, were discussed. The Work Group, set up in the previous meeting, had prepared the Terms of Reference for the working group's monitoring mission to Kunar, to monitor production of CCPP vaccine by MADERA, which was circulated to the participants. The Terms of Reference were approved. Haji Malang, from GAF, replaced Anbergul in the working group.

The monitoring mission of the group was planned to start on Monday 3 June 1996 from MADERA's office in Jalalabad.

FAO's new charging policy for Sheeppox vaccine was commented by many of the participating agencies. FAO defended the policy by providing some reasons, eg the privatization policy of FAO, etc.

May: $\quad$ (Chaired by Dr Salemi, PRB)

FAO announced that their Rabies vaccination campaign would start on 15 May 1996 in the eastern zone pravinces.

No discussion on the monitoting mission of the working group took place. 
PRB presented a detailed report on Veterinary / nutrition / livestock / general situation in
Badakhshan to the meeting.

June: (Chaired by Dr Salemi, PRB)

The working group had been able to accomplish the monitoring mission and a report was the meeting on was circulated to the participants. Dr Osmani-FAO, the team leader, briefed

CoAR announced that they have received reports on Rabies and FMD cases in Logar. FAO reported that Rabies vaccination campaign has been started and was normally going on. DCA accepted nominees from training programme was starting a new course of training and Logar, Wardak and Ghazni on 1 cacination campaign in

Dr Tino, DCA, announced that he was leaving Pakistan for Holland. His successor, DCA's new director, would be stationed in Herat.

July: (Chaired by Dr Salemi, PRB)

CoAR reported symptoms of Anaplasmosis in Sayedabad, Wardak. CoAR also reported that they have started cold chain services in Logar, Wardak and Ghazni. FAO updated the meeting
on their Rabies and Rinderpest vaccination campaigns.

Activity presentation by MADERA was included in the agenda. Copies of the presentation, prepared by MADERA, were circulated to the participants.

August: $\quad$ (Chaired by Dr Samsoor, DCA)

DCA announced that their poultry training programme in Charikar was starting its course of training on 1 September 1996. FAO updated the meeting on their Rabies and Rinderpest
vaccination campaigns.

MADERA, as a follow up of its activity presentation in the previous meeting, delegated $\mathrm{Dr}$ Emal to the meeting, who briefed the meeting on MADERA's new Straw Treatment
Programme.

\section{September: (Chaired by Dr Tahir, MADERA)}

DCA reported continued casualties in poultry at the result of an infectious poultry disease in Herat. MDC made a short briefing on their veterinary programme.

A handout of information on Ammonia Treatment of Straw, sent by FAO, was circulated to
the participants.

\section{October: (Chaired by Dr Tahir, MADERA)}

FAO said that according to its policy, the minimum charges for vaccination are set. However, veterinary workers can charge more as per agreement of beneficiaries.

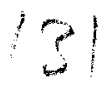


FAO briefly reported on NPPP conference, 22 to 25 September 1996 in Islamabad. Technical issues were brought up for discussion from the five FAO operational regions in the conference.

DCA announced that their paravet training programme is starting in December in Herat. DCA's paravet training programme in Charikar was reported to be running in Kabul after the recent military developments.

PRB reported that Afghanaid was doing BVW training in Badakhshan, which is duplication of PRB's programmes. It was suggested that Afghanaid be invited to report on their activities in the next meeting.

Dr M Sabir Tahir, MADERA, was elected as Acting Chairman of the Sub-committee with the agreement that election of new chairperson would take place in January 1996.

\section{November: (Chaired by Dr Tahir, MADERA)}

The two important items of the agenda, namely: "Briefing on Afghanaid activities in Badakhshan" and "Presentation on veterinary associations, by M Haroon" could be thoroughly discussed in the meeting.

Afghanaid briefed the floor on the their activities and responded the relevant questions.

M Haroon, Coordinator UVSA, briefed the meeting in details on Veterinary Services Associations. Handouts were circulated and the relevant questions were discussed.

The last Veterinary Sub-committee meeting for the year 1996 was decided to be held on 19 December 1996 in ACBAR office. The sub-committee will make an overall review on the veterinary activities in Afghanistan in 1996.

NOTE:

ACBAR would like to thank the members of the Veterinary Sub-committee for having maintained effective participation and cooperation which led to making the sub-committee successful in the past year. Their commitment for delivery of veterinary services to Afghanistan has proved of vital value for the country.

ACBAR, on behalf of other sub-committee members, extends appreciations to FAO for its continues support to the Veterinary sector. This support has, without reservations, made the back bone of existing veterinary services in Afghanistan.

It is hoped that the next year will be of more sincere commitment for assistance to Afghanistan and the sub-committee, together with its members, will achieve more beyond expectations.

Looking forward to cooperating with you in the future, wish you

\section{HAPPY NEW YEAR!}

A Jawed Ludin 


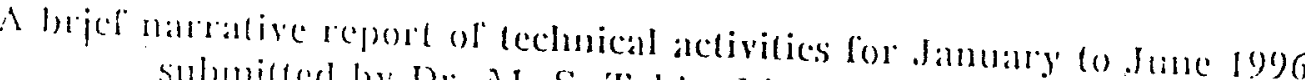 submiter by Dr. M. S. Tahir, Livestock Coordinalor}

\section{l'an 1: Cicoleral Introluction}

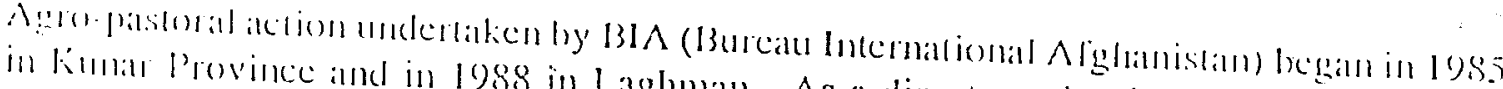

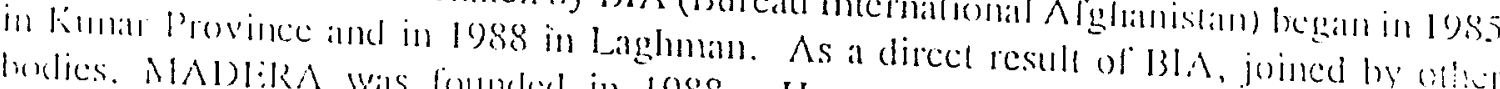
bodics. MADliRA wals founded in 1988. Ilowever 1991 was, above all, the rear

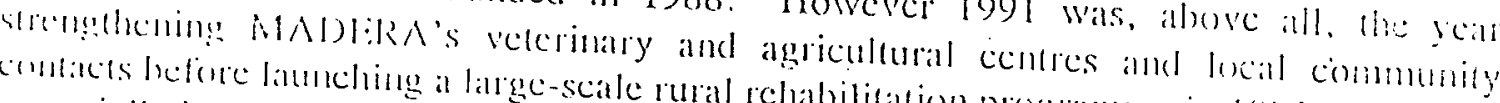

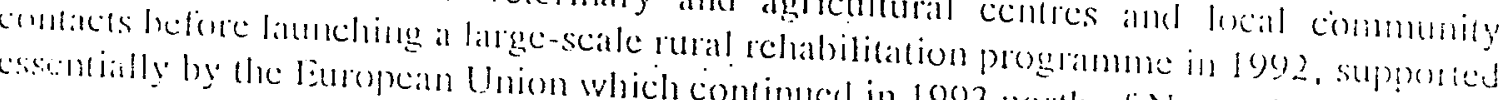

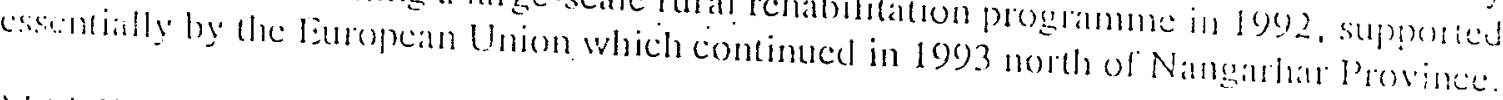

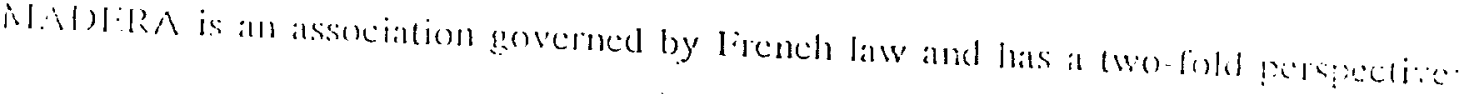

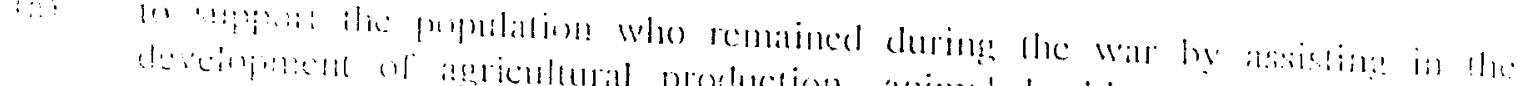

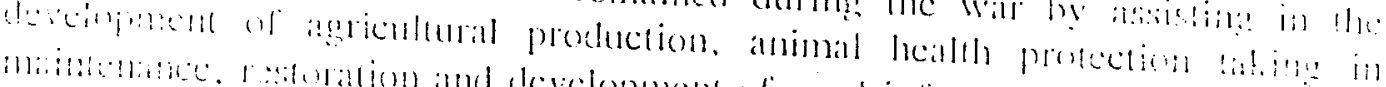

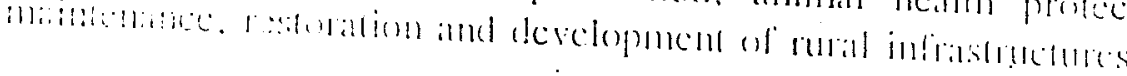

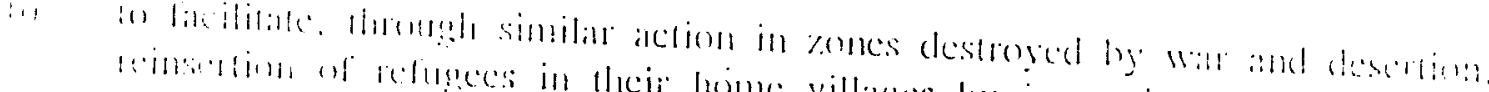

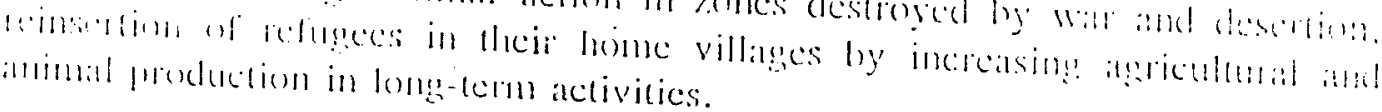

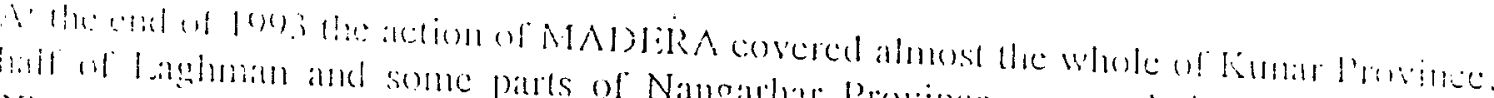

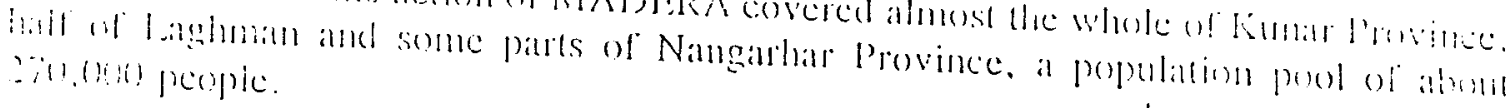

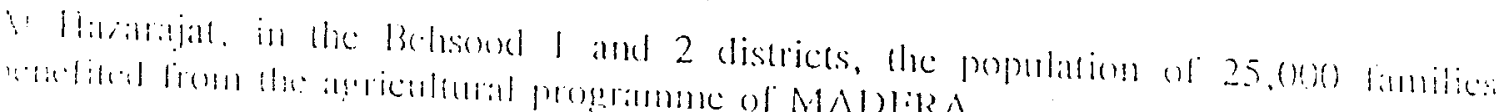

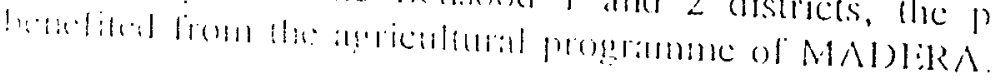

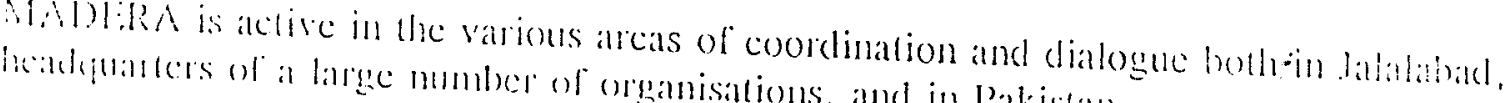

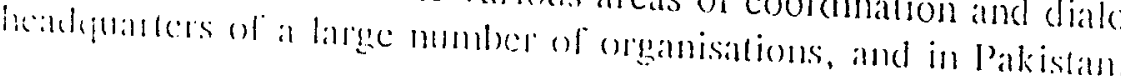

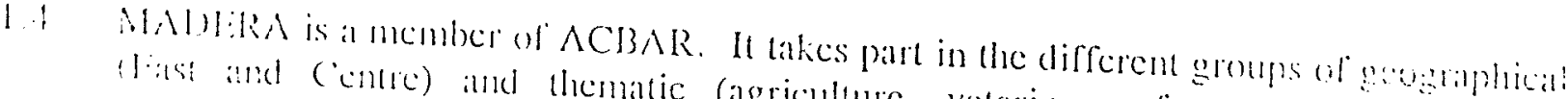

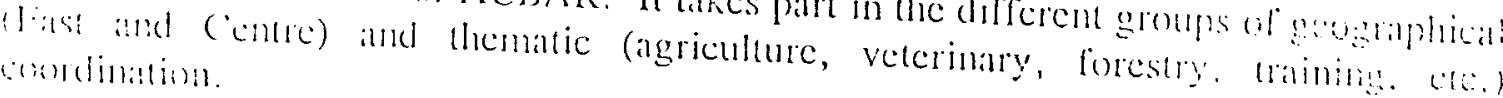

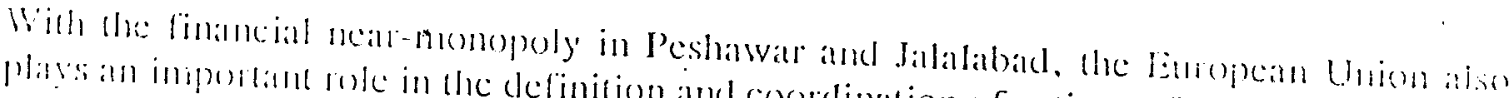
flass: an injontant sole in the definition and coordination of actions of the different actors lamkel. In his capacily. MADIBRA matntans close contace with the representatied at

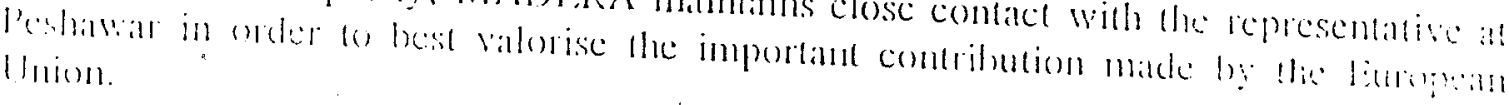

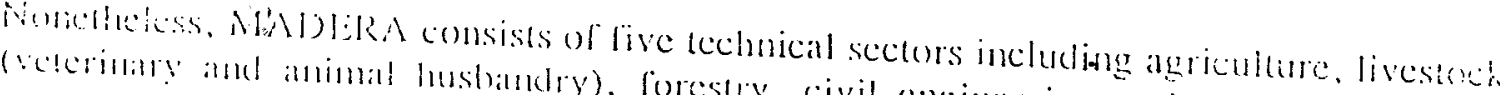

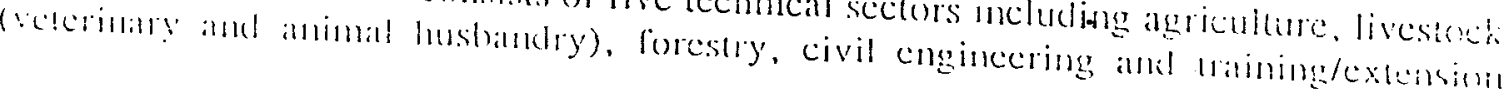


which carly out all the lechnical activilics of the association.

\section{l'al 2: Specilic introduclion}

2.1 Incrases in the worlel population demands increasing food supply. including animal protein year by yeals. Therefore, as velerinatians, we have an obligation to actirely (evelop) animal production.

As it is known that livestock sectors play an impontant wote in the national foconomy of Aghanistan. the main task and aim ol MADERA's veterinary sector is lo increase animal predaction in the target areals of our programmes which anc implementedin reducing amimal morbiclity and mortality. For this purpose, our clinics (1.5 original and 3 sul). clinics) are involved practically for consultation with anmal owners. for diagnosis and ucatment as well as for vaccinalion programmes against certain specific infoctious and

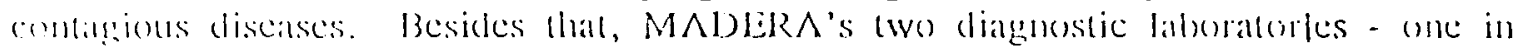
kumar and one in laghman province, are working well and analysing mostly parastologeical and bacleriological samples regularly which is very important for the

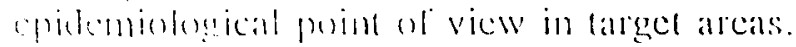

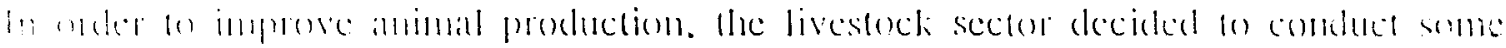

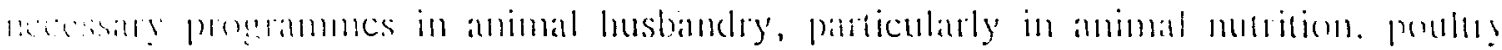

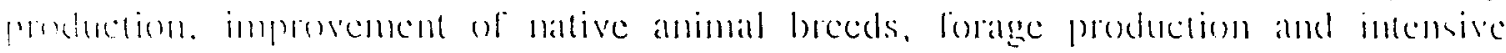

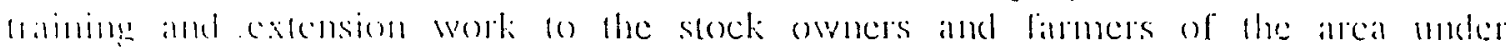
consideration.

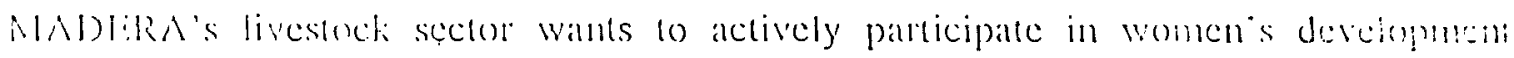
projects, such as women training in basic velerinaly heallh and small pouldry pactange

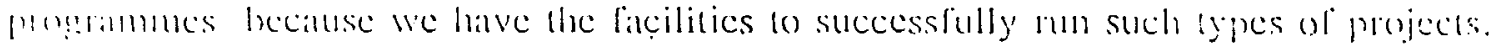

i'inl 3: Implenentalion Strategy

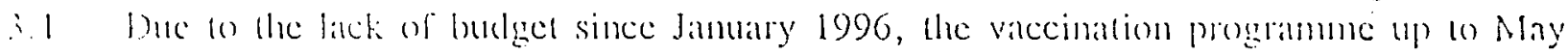
1996 has not been sucessful in target areas and some disadvantages ocemed in the procedure. The clinical activitics regalding examinations, diagnoses and trememe of different animals including poultry were beter and still ruming normally.

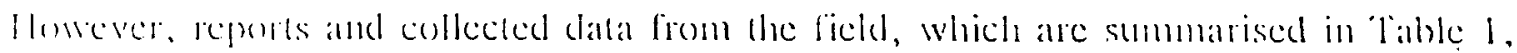

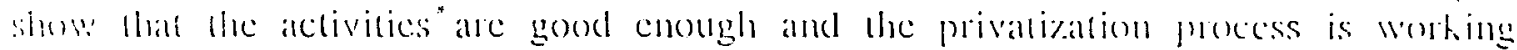
satisfictorily and the peasants of the areas agree to pay for the cost of medicines which is, in itself, a sicp lowards privatization.

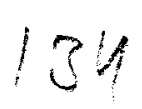


.3.5 Table (1) - Summary of the Month of $\Lambda_{\text {pril }} 1996$

\begin{tabular}{|c|c|c|c|c|c|}
\hline $\begin{array}{l}\text { Proficel } \\
\text { areal }\end{array}$ & $\begin{array}{l}\text { No. of } \\
\text { animals } \\
\text { cxamined } \\
\text { inc poultey }\end{array}$ & $\begin{array}{c}\text { No. of } \\
\text { animals } \\
\text { diagnosed . } \\
\text { or treated } \\
\text { inc. poultry }\end{array}$ & $\begin{array}{c}\text { No. of } \\
\text { animals } \\
\text { vaccinated } \\
\text { inc. poultry }\end{array}$ & Beneliciarices & Romanks \\
\hline 1.:1:!1minn & 1,848 & 11,336 & 488 & 1.183 & \multirow{4}{*}{$\begin{array}{l}\text { Only IISV } \\
\text { hats heen } \\
\text { inproduced }\end{array}$} \\
\hline Kim:1 & 1.01 .13 & $22.5 \% 2$ & 488 & .506 & \\
\hline l'clelt & 1.38 & 2,212 & - & 120 & \\
\hline Wey!n: & 6.5 & 5,853 & - & 123 & \\
\hline$\because 11\}-\{11: a \mid$ & $3,004.4$ & $41,99,3$ & 976 & 2,022 & \\
\hline
\end{tabular}

false 1li - Summary of the Nonth of Nay 1996

\begin{tabular}{|c|c|c|c|c|c|}
\hline 1.1!!1mmin & 2.675 & 4,820 & 24,649 & 1,107 & One vaccimation \\
\hline $1 \because 4 n: 11$ & $\therefore 13$ & 8,794 & 30,282 & si) & campraing of $A S V$ \\
\hline 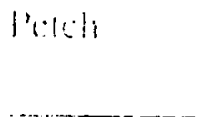 & 5.17 & 97.5 & 20,966 & 65 & $\begin{array}{l}\text { E IISV during lass } \\
\text { weck of Maly. }\end{array}$ \\
\hline Whon: & 4.3 & 1,914 & 17,104 & 60 & $\begin{array}{l}\text { and combinued } \\
\text { (11) } 10.5 .6 .96\end{array}$ \\
\hline Sublotolal & 2,5018 & $16,50) 3$ & 93,001 & 1,831 & \\
\hline
\end{tabular}

3.7 Table 1f - Summuary of the Month of June 1996

\begin{tabular}{|c|c|c|c|c|c|}
\hline Anglminn & 1.171 & $2,6.35$ & 12.934 & 7.4 & \multirow{4}{*}{$\begin{array}{l}\text { Vitcintation } \\
\text { campaign } \\
\text { continued up } \\
105.6 .96 .\end{array}$} \\
\hline Kunall & 33.5 & 8,159 & 15,095 & 384 & \\
\hline Pech & 58 & 1,541 & 1,583 & 174 & \\
\hline Weygal & 85 & 3,835 & 16,760 & 145 & \\
\hline$\therefore(1)|-| 06: 1)$ & $1: 9419$ & 16,170 & 46,372 & 1,447 & \\
\hline Crand l'or:al & $57,70,3$ & $160,(0) 32$ & 196,327 & 10,648 & \\
\hline
\end{tabular}


Tahle 1 - Summary of the Technical Activities in Januany 1996

\begin{tabular}{|c|c|c|c|c|c|}
\hline $\begin{array}{c}\text { Propicet } \\
\text { arrai }\end{array}$ & $\begin{array}{l}\text { No. of } \\
\text { animals } \\
\text { cximined } \\
\text { inc. pouldey }\end{array}$ & $\begin{array}{c}\text { No. of } \\
\text { animals } \\
\text { diagnosed } \\
\text { or trealed } \\
\text { inc. pouldry }\end{array}$ & $\begin{array}{c}\text { No. of } \\
\text { animals } \\
\text { raccinaled } \\
\text { inc. poultry } \\
\text { ! }\end{array}$ & Beneficiaties & Rcmanlis \\
\hline 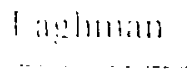 & 7.446 & 8,752 & $13 ; 894$ & 739 & \multirow{4}{*}{$\begin{array}{l}\text { Ony ASV. } \\
\text { IISV. slecep } \\
\text { pos and } \\
\text { NDV were } \\
\text { infueluced }\end{array}$} \\
\hline KLibil & 9.280 & 12,635 & 3.398 & 688 & \\
\hline lekh & $2.7 \cdot 1 \cdot 1$ & $2.30) 3$ & 5.5 .39 & 270 & \\
\hline $11: 19: 11$ & 3.855 & 4.003 & 2,700 & 89 & \\
\hline$(401)-|a t: 1|$ & $2.3,155$ & 23,193 & $25,5.31$ & 2.1168 & \\
\hline
\end{tabular}

Tahk 16 - Summary of the Month of lebruary 1996

\begin{tabular}{|c|c|c|c|c|c|}
\hline | & 5.163 & 5,953 & 9.749 & 7.36 & \\
\hline Sumar & 7.152 & $8,(642$ & - & 344 & slecep pos: and \\
\hline l':31 & 1.227 & 1.237 & 2,731 & 901 & NDV were \\
\hline$\because \because ! ! !: 1 !$ & 202 & 207 & - & 40 & introcluced \\
\hline Sinfr-tolal & 12.83 .1 & 16,159 & 12,480 & 1,210 & $\therefore$ \\
\hline
\end{tabular}

lable 16: - Summary of the Month of March 1996

\begin{tabular}{|c|c|c|c|c|c|}
\hline 1 1:16man & 8.338 & 16,950 & 7,080 & 1,301 & Only LISV. \\
\hline Bmmin & 5.113 & $12, .525$ & 4,314 & 461 & shecp pox and \\
\hline $\ln 11$ & 117 & 3.875 & 2.073 & 168 & NIDV were \\
\hline$\because \because \cdots: \cdots 1$ & 0.5 & 7.658 & 4.500 & $1: i 0$ & inrroluced \\
\hline$(5,1)-\{0|a|$ & $1,3,96.3$ & 41,014 & 17,967 & 2,070 & \\
\hline
\end{tabular}




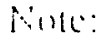

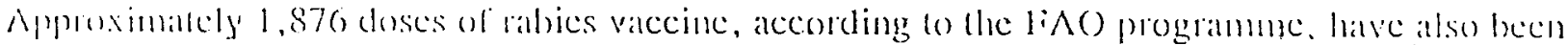

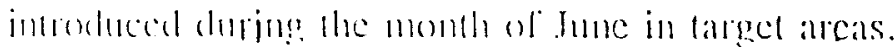

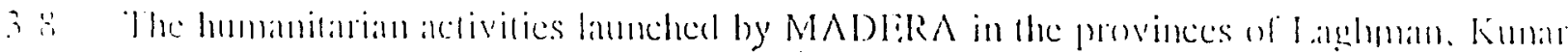

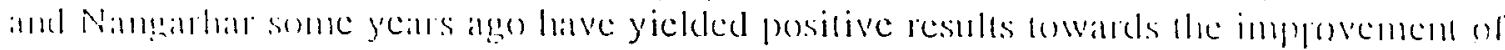

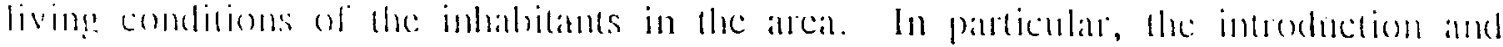

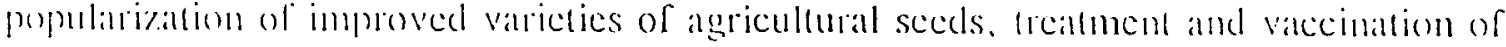

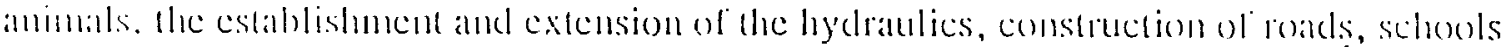
itnd some hamelictalt projects, as well as ofler projects, have proved heneficial for the peasants of thesc watr-tom provinces.

:1) Since 1 July 1996, the livestock sector, in order to improve animal production, stauted

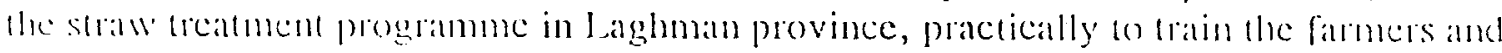

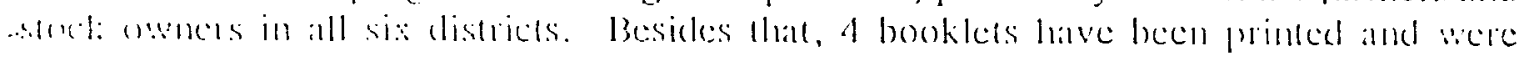

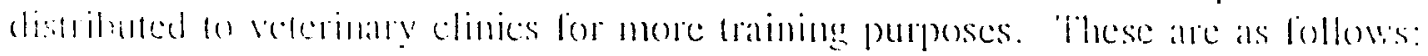

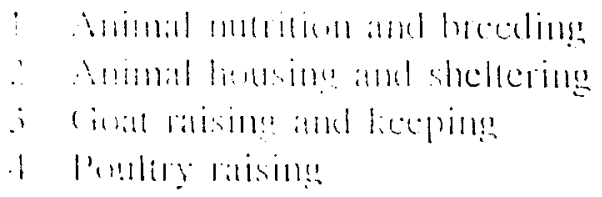

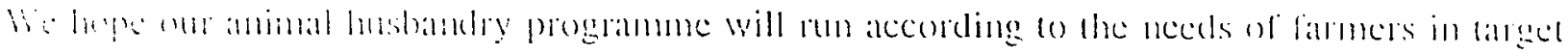
: $: 1, \cdots ! \cdots$

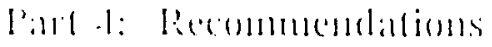

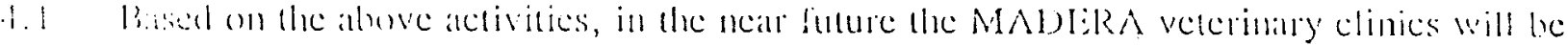

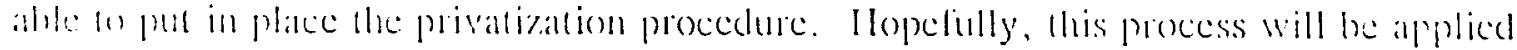

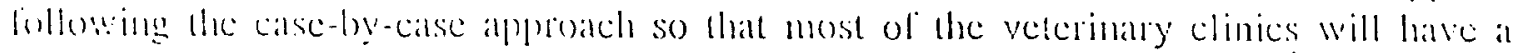

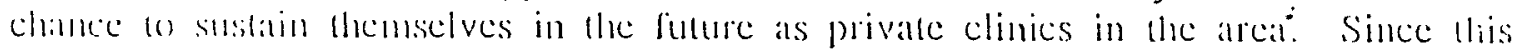

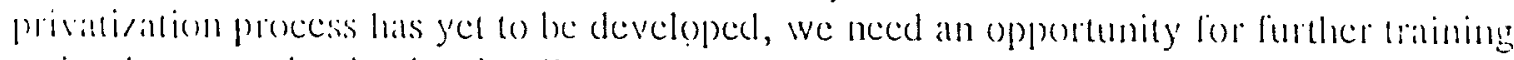
wimplement privatization in all target arcas.

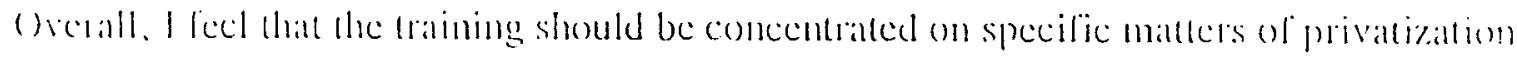
al: an essential sicp in the development of the down activities. 


\section{Livestock sector \\ A brief report of technical activities for Jan. to Nov.1996. \\ Submitted by Dr.M.Taher \\ Livestock Sector coordinator \\ Dated, 18 , 12, 1996}

\section{Introduction,}

Increases in the world population, demands, increasing food supply, including animal protein year by year, therefore, as veterinarians we have an obligation to actively develop animal production.

As you know, live stock sector plays an important role in the national economy of Afhanistan , therefore, the main task and aim of MADEIRA's veterinary sector is to increase animal production in target areas of our programs, which are implemented in reducing animal morbidity and mortality.

For this purpose, our technical staff are involved practically for consultation with animal owners, for diagnoses and treatment as well as for vaccination programs against certain specific infectious and contagious diseases.

Beside that, our two diagnostic laboratories are working well and analyzing mostly parasitological and bacteriological samples, which is very important for the epidemiological point of views in target areas.

However, reports and collected data from the field which are summarized in the following tables show that the activities are good enough from Jan. to Nov. 1996 and the privatization process is working satisfactorily and the peasants of the area agree to pay for the cost of medicines which is, in itself, a step towards privatization :

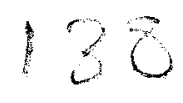


Summary of the technical activities of the livestock sector regarding the examination of sick animals, diagnoses, treatment and vaccination of different animals from Jan. to Nov.1996.

\begin{tabular}{|l|l|l|l|l|l||}
\hline Months & $\begin{array}{l}\text { No. of } \\
\text { animals } \\
\text { examined in } \\
\text { the site }\end{array}$ & $\begin{array}{l}\text { No. of } \\
\text { animals } \\
\text { diagnosed } \\
\text { and treated }\end{array}$ & $\begin{array}{l}\text { No. of } \\
\text { animals } \\
\text { vaccinated }\end{array}$ & Beneficiaries & Remark \\
\hline Jan. & 23355 & 28193 & 25531 & 2068 & \\
\hline Feb. & 12834 & 16159 & 12480 & 1210 & \\
\hline Mar. & 13963 & 41014 & 17967 & 2070 & \\
\hline Apr. & 3094 & 41993 & 976 & 2022 & \\
\hline May & 2058 & 16503 & 93001 & 1831 & \\
\hline Jun. & 1949 & 17739 & 54986 & 2442 & \\
\hline Jul. & 3878 & 24852 & 47936 & 3098 & \\
\hline Aug. & 2360 & 15229 & 7804 & 1639 & \\
\hline Sep. & 2109 & 8064 & 802 & 1235 & \\
\hline Oct. & 2076 & 17027 & 121109 & 5011 & \\
\hline Nov. & 1842 & 24129 & 5656 & 1444 & \\
\hline Total & 69518 & 250902 & 388248 & 24070 & \\
\hline
\end{tabular}


Peshawar, July 25, 1996

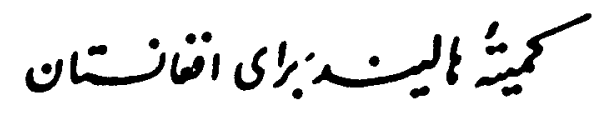

General update by DCA

1. Refresher course about pregnancy diagnosis through rectal exploration and artificial Insemination technique for artificial and livestock directorates personnel of Nangarhar Agricultural department and Hada farm veterinary officer. From 30th June to 15th July 1996, 10 participants were present.

2. The following activities are in progress :

- Survey about food basket programme in Naser Bagh refugees camp.

- Refresher training for veterinary personnel in Herat/ Parwan.

- Shifting of PV training programme to Charikar.

3. Medicine store activity in Ghazni to supply good quality veterinary medicine for veterinary personnel is improving and running very well.

4. Paravet training course in Herat completed its period on 17 July 1996.

5. Booklet (manual) about calf rearing in Pushto which has been prepared by Dr. Samsore is in progress. 


\section{Agency for Rural Development of Afghanistan}

Rel.No

Dated.11-1?...1996

To: Ahmad Jawed Ludin

Information Officer

ACBAR

Peshawar

Subject: $\quad$ Activities Report-ADF/96/01

Dear Sir,

According to the decision taken in veterinary Sub-Committee meeting, on 28 November, 1996 summary of the project activities is sent to you for information and necessary action.

With regards

Sincerely Yours

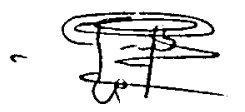

Shah Mahmoud Safi

Project Coordinator 


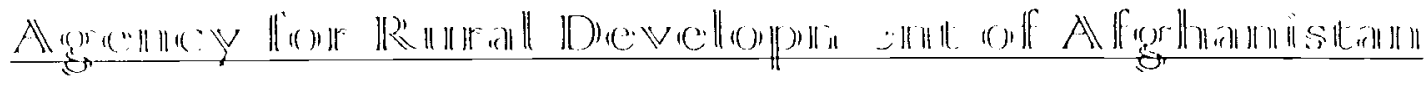

$$
\begin{aligned}
& \text { Activity Report } \\
& \text { Project - ADF/96/01 }
\end{aligned}
$$

ADl: has velerinary services in 21 districts of Nangarhar, Kuner and Laghman provinces. The organization main office is in Peshawar and field office in Jalalabad cily.

Ihe velerinary project was funded by $l \wedge \Omega$ and has been carried oul by a project manager, one monitor. 13 DVM, one assistant DVM and 42 paravets.

The activities which have been done by $A D$ ) li are as forlows.

- The translier of live VliUs in Nangarhar province from GAF and one VIUS in Laghman province from 1$)(\wedge$ to $\wedge \mathrm{DP}$ was done in January 1990

- Refresher training courses for paravets have been organized at ADF field office. 26 paravels fiom our clinics have been refreshed in the courses.

- The vaccines received from FAO have been provided to the VI:Us in Nangarhar, Kunce and Laghman provinces and the empty bottles have been collected to the FAO regional oflice.

- The lirst vaccination campaign organized by the VIVU incharges. 53 VFUs staff together with 84 13VWs carried out vaccination campaign in the project location.

However, a total of 163115 animals and poultry were vaccinated against Anthrax. Enteronceamia, Slieep Pox and New Castle diseases and 14863 animals were treated during the campaign.

- Rabics vaccinalion campaign was started on 27 Na:, 1996. A total of 5143 dogs and other animals were vaccinated against rabies disease in 21 districts of Nangarhar, Kuner and Laglman provinces. The campaign was carried out by the VIUS persomel and BVWs.

- The second vaccination campaign was started on 17 November. 1996. The activities reports from VIU Us have not been received yet.

- Refresher training courses for active BVWs have been organized in some VFUs and our field office. 81 active BVWs have been refreshed in the courses. In addition 24 active BV'W are under training. They will be provided with refresher kits very shortly.

- The incidents of Black Leg and FMD diseases have been reported fiom some districts of project location. The BQV vaccine received form FAO was used as campaign in the

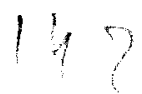


mentioned areas. However, due to unavailability of FMD vaceine the infected animals have been treated.

- Five literate people were selected for BVW from Nooristatn district, Laghman province. After a month successful training, fiee kits of instrument, medicines and vaccines were provided to them.

- Two VFUs buildings are under construction.

- The VFUs activities in 21 districts of Nangarhar, Kuner and Laghman provinces have been monitored regularly.

- According to the progress reports received from the VFUs, a total of 544000 animals and poultry have been vaccinated against Anthrax. Enterotoxeamia, Black Leg Sheep Pox, Rabies and Newcastle diseases, and 322000 animals have been dewormed /treated in 21 districts of project location from 1st Jan. to 30 Oct., 1996.

With regards. 


\section{FAO ACTIVITIES}

(1 January - 31 June 1996)

FAO's activities in this period have been implemented by 13 IPs through 244 VFUs in 244 districts, 27 provinces of Afghanistan.

\section{Vaccination:}

Targetted number of animals for vaccination: $14,850,000$

Actual number of vaccinated animals: $\quad 5,884,553$

Acheived percentage: $\quad 40 \%$

Rinderpest vaccination campaign was conducted in Khost. The campaign, which was started in 1995 , has covered 9 districts $(100,887$ head cattle were vaccinated), while two other districts (Chamkani and Dand Wapatan) would receive it in the near future.

Rabies vaccination campaign was carried out in Mazar (and some other northern areas), Nangarhar (and other eastern areas), Qandahar and Ghazni. A similar campaign will also be undertaken in Herat.

\section{Deworming:}

The targetted number of animals for deworming service has been $2,982,000$. Out of this, $2,140,766$ animals have been vaccinated. The achieved percentage is 72 .

\section{Training:}

Training of 177 new BVWs was targetted. So far, 18 BVWs are trained (10 \%). Besides, out of 665 BVWs targetted for refresher training, 153 have been trained $(23 \%)$. Refresher training was also provided for a total of 399 field veterinary staff (52 DVM, 45 asst vets, and 302 paravets).

Poultry training has been an important portion of FAO's traning programme. Within this programme, besides training, the trainees were provided with locally manufactured kerosene incubators, 400 fertile eggs, and $70 \mathrm{~kg}$ stuff, including food, vaccine and medicine. Details of the traning were as bellow:

Helmand: $\quad$ ADF trained 30 women and 10 men;

Herat: $\quad$ VSR trained 80 men and 20 women; a second project will start shortly (40 trainees)

Mazar: $\quad 30$ people (14 men and 16 women, including 9 widows) were trained by Mujda poultry farm;

Kabul: $\quad$ WOA trained 30 men and women trainees; in a second project 110 people (men and women will be trained;

Farah: $\quad$ WRCA trained 10 persons ( 7 men and 3 women);

Khost: $\quad$ The project in Khost has not started yet.

PAIHAM: This is another training programme. Under this programme, 10 people (5 veterinarians and 5 animal husbanders) have been trained as initiators. They work to educate farmers on animal health, nutrition and production. They will maintain links between veterinary workers and farmers. They also convey new veterinary masseges to farmers and BVWs.

Women Development Programme is also part of FAO's activities which include training. This programme is run in Jalalabad, Helmand, Mazar, Aqcha, Jawzjan and Laghman. 


\section{Treatment:}

$1,485,000$ sick animals were targetted to be treated. So far, 831,952 animals have been treated $(56 \%)$. In addition to it, 371,355 cases were also treated against Ecto Parasites.

Animal production:

A total quantity of $38 \mathrm{MT}$ Molasses were supplied for veterinary services in Khost, Ghazni and Nangarhar. Shortly, $20 \mathrm{MT}$ more will be supplied to Kabul, Wardak and Logar. $10 \mathrm{MT}$ will be given to MADERA on their request.

Totally, $3600 \mathrm{~kg}$ of straw treatment with Urea was supplied to Paktai, Ghazni and Nangarhar.

\section{Others:}

Fodder Crop Demonstration was conducted in Jalalabad, Khost, Herat, Mazar and Baghlan.

The diagnostic lab in Mazar has been normally working.

Evaluation teams have been regularly sent to fields.

An NPPP workshop was conducted. 


\section{German Afghanistan Foundation Veterinary Project}

\section{Activity Report from 1st January 1996 up to 30th November 1996.}

Veterinary project of German Afghanistan Foundation is running 58 Veterinary Field Units in 58 districts . Kabul, Logar, Nangrahar, Ghazni, and Paktia provinces of Afghanistan .

\section{OBJECTIVE OF THE PROJECT.}

Following were the main objectives of the project.

A.To improve livestock health and production, through support to village based veterinary services.

B.Provision of professional and logistic support to veterinary personnel deployed in the project.

C.To educate the local community in basic veterinary aid.

\section{OUTPUT TARGET ;}

GAF veterinary services in 58 districts. five provinces of Afghanistan. The organization main office in Peshawar and field office in Khost and Nangarhar province.

The veterinary project funded by FAO and has been carried out by veterinary coordinator, monitoring supervisor, four monitors, 26 DVM, 19 Assistant DVM and 106 pravets.

\section{Activities;}

1, Totaly 23 clinics were transferred from other NGOs to GAF on January 1996.as following.

The transfer of two VFUs in Kabul province from ADF.THREE VFUs in Logar from DCA . Five VFUs in Nangrahar from DCA. Seven VFUs in Ghazni province from DCA. one VFU in Nangrahar from Government, and five VFUs in Paktia province from PRB.

2, GAF transferred total 15 VFUs to the different NGOS.OON the beginning 1996. as following. 6 VFUs in Kapisa and Parwan provinces were transfered to PRB. 5 VFUs in Nangrahar Province were transfered to ADF. 2 VFUs in Bamyan province transferred to AOR. 2 VFUs in Bamyan province were transferred to OXF was done in January 1996. 


\section{Vaccination;}

The vaccines received from FAO have been provided to VFUs in Kabul, Logar, Nangrahar, Ghazni, and Paktia provinces and the empty bottles have been collected to the FAO regional office.

Totally 1392446 numbers of Live stock have been vaccinated against different infectious diseases Anthrax,

Enterotoxceamia, Sheep Pox, Black Quarter, and New Castle diseases.

The incidents of FMD diseases have been reported from some districts of project location. Due to unavailability of FMD vaccine the infected animals have been treated.

The first Rinderpest vaccination campaign was started on 14th July 96.finished 6th August 1996. A total of 44642 cattle were vaccinated against rinderpest diseases in Bak , Jaji Maidan, Alisher, Shamal, Ismaial Khil, Nader Shakot, Yaqubi, Khost, Tani, and Gurbuz VFUs of Khost province.

The second rinderpest vaccination campaign was started on 21.09.96 finished on 24.11.96. A total 108879 Cattle were vaccinated against rinderpest diseases in Jaji Maidan, Bak, Yaqubi, Alisher, Shamal, Gurbuz, Tani, Ismail Khil, and Khost Center veterinary clinics.

Rabies vaccination campaign was stared on 27 May 1996 A total 8525 numbers of doges, and 30 numbers of other animals were vaccinated against rabies disease in 42 VFUs of Kabul, Logar, Ghazni, Nangrahar, and Paktia veterinary clinics.

\section{Deworming;}

554438 numbers of livestock have been dewormed during the reporting period.

\section{Treatment;}

A total 332824 number of livestock have been treated against different diseases.

6-During the project period 16 farmer have been newly trained for 30 days as BVW in different districts. The course were conducted through our veterinary trainer. 
7-During the project period 157 active BVWs were refresher trained for seven days. in different clinics and the courses were conducted through VFUs veterinarian and granted with necessary kits.

8-A total 17 Honda/Japanese Motorcycles and 36 Bicycles were purchased and delivered to the field Units.

9-32 Bicycles have been distributed to those BVWs who are active.

10-Veterinary instruments and other equipments were provided to 58 VFUs during the project period.

11-At least six active BVWs working in each district area.

12-Each clinic has been monitored 6 time during the year.

13-34 professional VFUs personnel shared in veterinary Union and they deposited 4714 US Dollar in the UVSA bank account.

1.4-The following veterinary medicines were provided as loan to veterinary association.
a. Nilzan drench 1 litter
b. Systamex $450 \mathrm{ml}$
c. Syatamex $100 \mathrm{ml}$
No-2000 litters. No-2000 Bottle. No-4000 Bottle.

15-According to an agreement with FAO, GAF has been " started the 121 VFUs signboards build and repaint from different NGOs of $\mathrm{PRB}, \mathrm{ADF}, \mathrm{ADA}$, and KVC veterinary field units signboards.

16-A total 7 students were introduced to the DCA veterinary training Center and trained as paravets after graduation they were employ in GAF VFUs.

However 7 students more under training as paravet training.

17-PIHAM [Animal Health and Production Module; AHPIM] is a herd health and production programme which aims to improve the quality of livestock services within Afghanistan. it is an approach based on gaining a greater understanding of farmers needs and formulation a response to those needs . PIHAM consists of two components; a seven step monitoring system, and a programme of quality control. 
The implementation of PIHAM within Afghanistan has divided into two phases; a pilot phase and a replication phase. During the pilot phase 12 initiators from Nangrahar, Paktia, Kandahar, Herat, and Mazar region will be trained to test and make modifications to the PIHAM programme. The pilot phase with practical work in the field from March 1996 to January 24th 1997 a training of trainee course will be probably conducted in March 1997 for PIHAM initiators in order to be as trainers in replication phase. The replication phase will be implemented from 1997 onwards. The intention is that PIHAM will be implemented through the existing Veterinary Field Units by the veterinarians. During the replication phase the initiator will begin training the VFU staff to use the PIHAM approach.

Thank you.

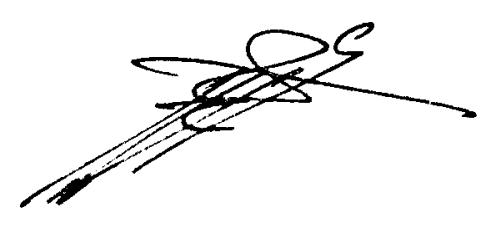

Dr.A.Ghafoor

Director and Veterinary Coordinator.
GAF Peshawar. 


\section{Afghan Development Association Veterinary Services in South West \& South Central Afghanistan 1st Januay 1996 to 31st August 1996}

\section{OBJECTIVES:}

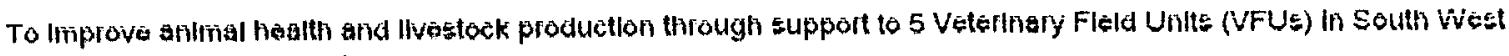
and South Central Aighanlstan.

To promote the development of district level self-sustaining basic animal health care systems.

\section{OUTPUT}

Stated:

5 VFUs establlshed and veterinary services provided through these VFUs

Actual:

According to an agreement with FAO, ADA started the running and supporting VFUs In Kandahar. Zabul and Wardak provincns. Now ADA is running totally 23 VFUs in the four provinces.

During project time $A D A$ vaccinated a total of 496,831 animals and treated a total of 637,473 animals against different diseases Iri the project areas.

For tralning of Afghans in veterinary services, a total of 22 Afghans were trained as Baslc Veterinary Workers (BWWs) by ADA veterlnary program and equipped with kits. Blcycles were also distributed to active BWWs through the program.

The following table is showing the detail about veterinary activity in the four provinces.

\begin{tabular}{|c|c|c|c|c|}
\hline \multirow{2}{*}{ Province } & \multicolumn{4}{|c|}{ Type of Activitles } \\
\hline & Vaccination & Treatment & $\begin{array}{c}\text { Deworming } \\
\text { Treatment }\end{array}$ & : Fraining BWWs \\
\hline Uruzgan & 178,857 & $52,45 ?$ & $205,5,28$ & Q \\
\hline Zabul & 103,832 & 33,401 & 140,428 & 14 \\
\hline Kandahar & 62,455 & 17,399 & 56,101 & 2 \\
\hline Wardak & $151,8 B 7$ & 25,053 & 101,111 & 6 \\
\hline Total & . $\quad 496.831$ & 128,305 & 509.168 & 27 \\
\hline
\end{tabular}

During project time, monitoring vists were also done by project monitors and FAO monitors on regular basis.

The project monitors and project technicel steff were also providing necessery information and training to the livestuck owners and were raising their awareness about the project and the program.

\section{ATTAINMENT OF THE OBNECTIVE:}

The project objectlves were attained successfully. ADA established and supporting 23 VFUs in the project area provided veterinary services accordingly. A total of 109 Afghans were tralned as Baslc Veterinary Workers (BWWs) in the project araa. Through this project anlinal heolth and animal production as well as people health hove been Improved considerably and economic situation is getting better with compare to the previous years. 


\section{PAMIR RECONSTRUCTION BUREAU \\ VETERINARY PROJECT \\ ACTIVITY REPORT OF VFUS}

PRB is running 54 dinics in 54 districts of 6 provinces. The clinics are managed and supported through 3 field offices located in Khost, Kabut and Takhar province.

Activity report of each field offices are out insd in the following:

\section{(I). Activity Report of Kabul Field office}

(from ist January to 30 th september 19ss)

1. PRB has a total of 13 VFUs operaing in 13 districts of parwan and Kapisa provinoss.

2. A total of 15 DVM, 20 paravets and assistant veterinarians are employed in thase VFUs.

3. At least 5 BWs are working in each clinic.

4. Each clinic has been monitored at least 6 times during the :ear.

5. Two vaccination campaign have been implemented against different infectious diseases. Also, a vaccination campaign against Rabies has been carried into execution in Bagram and Charikar areas.

6. A total of 15 DVMs and paravets have been refreshed by fAO in the area.

7. A total of 24 BVWS have been refreshed and equipoed with kits of necessary medicine and equipments.

8. Three techrical staff ( 2 ovis and 1 paravet) have been newly employed in Nejrah, Chartar and Panjshir clinics.

9. A total of 375455 different animals have been vacoinated against different infectious diseases.

10. A total of 184948 animals have been treated against different diseases.

11. A total of 115880 animals have been dewormed.

12. Two new sub-clinics have been established in Jamal Agha (Kohestan) and Pachaghan of Nejrab district.

13. Some technical equipments have been distributed to some of the clinics as needed. 
(II). Activity Report of Khost Field office (1si January lo $30 t h$ september 1996)

1. A tolal of 18 veterinary clinics in 18 districts of paktika province have been running and supported through this field". office of PRB.

2. A total of 3 DVM, 5 Assistant veterinarians, 24 paravets, 4 vaccinators and 12 BVWs have been carrying on veterinary services in these clinics.

3. A total of 35141 animals have been treated against different diseases.

4. A total of 183327 animals have been dewormed during the reporting period.

5. A total of 308181 animals have been vaccinated against different infectious diseases.

6. A tolal of 8 BVWs have been newly trained and granted with necessary kits.

7. A total of 28 DVMs. Assistant veterinarian and paravets have been refreshed by $F A O$ in the area.

8. Almost 8 times the clinics have been monitored.

9. A total of 3 bicycles and 7 motorcycles have been distributed to those clinics which still had hot received the equipments.

10. Almost 10 clinics have been provided with technical equipments and logistic support as needed.

11. Two persons from two districts were introduced to DCA paravet course for training.

(III). Activity Report of PRB field office in Takhar (From 1st January to $30 t h$ september 1996)

1. A intal of 22 vFus in 23 districts of 3 northern provinces (kundus, Takhar and Badakhshan) have been running and suppowted through this field office.

2. A total of 10 DVMs, 2 Assistant DVM, 32 paravets and 79 BVWs have been carrying on veterinary services in these clinics.

3. During the first three quarters of the year a total of 252692 anima 15 have been treated against different internal parasites and a total of 68705 animals have been treated against different external parasites. 
4. Two vacoination rampaign have been implemented through which a total of 1197642 animals have been vacoinated againot different infectious diseases.

5. For the second time, a cencus of animals has been carried into execution in all of the districts.

6. Three DVMS, one Assist. DVM and a paravet have been newly employed in the vacant position.

7. Four persons from four districts where we had been in lack of technical personnel have been introduced to doA paravet courses for training.

8. A refresher course for 10 DVMs and another refresher course for 35 paravets have been carried on in Taloqan city during the reporting period.

9. A total of 59 BVWs from different clinics have been refreshed and they were granted kits of instruments.

10. Five monitoring missions have been conducted from the clinics and practical work and technical support have been provided to them.

11. The required equipment and logistic support have been purchased and distributed to the clinics as requested.

12. Some technical instruments needed by the clinics are present 1 y supplied according to their request and it will be distributed to them during the following monitoring mission.

13. Due to shortage of animal remedies in the clinics, their medicinal needs have been purchased in peshawar and distributed to the clinics against five month salary of their technical staff.

14. Practical guide books and some books of first aid veterinary services have been distributed to DVMs, Assist. veterinarian, Paravets and Buws respectively.

15. UVSA was established in Taloqan and all preparation were provided for it. A total of 33 person have received membership of the union and 6000 Us $\$$ was transferred by PRR to its account.

16. A clinic building for the faizabad vfy has been constructed.
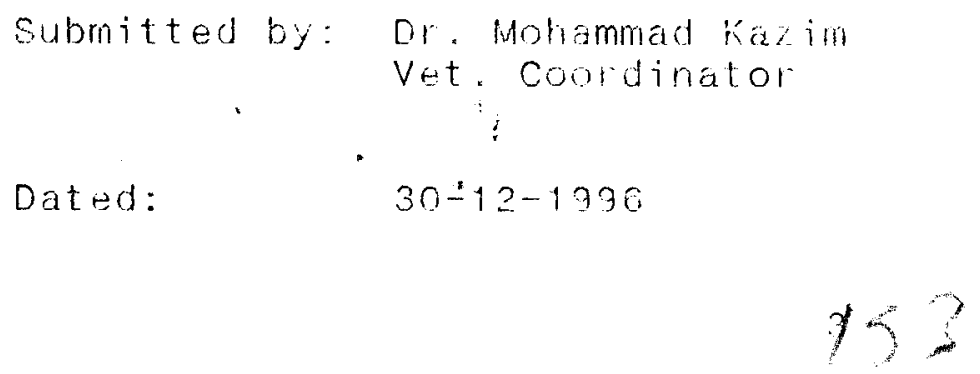
List of The Established VSAs

\begin{tabular}{|c|c|c|c|c|c|}
\hline Date of Establishment & DVM & Ast.DVM & Paravet & Total & Shares \\
\hline \multicolumn{6}{|c|}{ Nangarhar } \\
\hline 09.07 .1996 & 11 & 0 & 9 & 20 & $\$ 4600$ \\
\hline \multicolumn{6}{|c|}{ Khost } \\
\hline 10.03 .1996 & 7 & 0 & 26 & 33 & $\$ 4337$ \\
\hline \multicolumn{6}{|c|}{ Kandahar } \\
\hline 20.08 .1996 & 1 & 6 & 18 & 25 & $\$ 5000$ \\
\hline \multicolumn{6}{|c|}{ Herat } \\
\hline 26.08 .1996 & 3 & 1 & 2 & 6 & $\$ 1200$ \\
\hline \multicolumn{6}{|c|}{ Takhar } \\
\hline 23.09 .1996 & 10 & 1 & 22 & 33 & $\$ 6600$ \\
\hline \multicolumn{6}{|c|}{ Ballkh } \\
\hline 17.10 .1996 & 5 & 4 & 3 & 12 & $\$ 2400$ \\
\hline Total & 31 & 12 & 80 & 129 & $\$ 24137$ \\
\hline
\end{tabular}

Totally, a sum of US\$ 6000 was paid for furnishing the stores. They have rented a store in the centers
of the provinces. Also, a total of US\$ 1200 was paid for rent of the stores.

We got quotations from serveral companies. Recently, we gave an order to Norbrook Company Northern Ireland for 4000 vials Alamycin LA $100 \mathrm{ml}$ and 4000 Norocillin LA $100 \mathrm{ml}$. We will print a book "Basin Elements of Trade in Afghanistan" and we will open a training course in this regard for the chairnan and one member of the board of management of VSAs. 


\section{Guidelines for Veterinary Services Associations}

\section{Draft}

\section{Chapter One:}

1.) Name of Association: Veterinary Services Association (VSA)

2) Area of Activities: Regionally based

3) Activities: A regionally-based Veterinary Club organized to:

4) Procure and distribute veterinary medicines, vaccines and equipment, such as to preserve their potency/quality, in accord with manufacturers' directions, and available at all times in all regions on demand from shareholders or with minimal delay.

5) Promote the use of veterinary medicines, vaccines and equipment according to manufactures' instructions and good veterinary practices through problemoriented education

6) Maintain a list of veterinarians, assistant veterinarians, paraveterinarians (both members and non-members of the VSA), and basic veterinary workers (BWWs) in the region.

7) Promote ethical sales practices through locally agreed rules of procedure and continuing education.

\section{Chapter Two:}

Association strategy and employment:

8) Membership in the Association is voluntarily.

9) Members should perform their activities based on Islamic regulations and scientific requirements.

10) The Association will not affiliate with any political party and is completely impartial!

11) Persons eligible for membership are Veterinarians, qualified Assistant Veterinarians and Paraveterinarians. (precise definitions are required here, we can discuss):

12) The membership fee equal to one share in the Association is US $\$ 300$ or the equivalent in any other currency based on the current ex-change rate of the day.

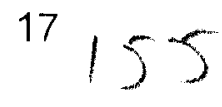


13) Each member of the Association may, if he/she wishes, purchase more than one share.

14) The Association will establish area-based offices in the Regions which will be led by a chairman and two to four members who form the board of management.

15) Chairman and members of the board of management will be selected through elections and will serve for a period of one year, with eligibility to be re-elected yearly for a maximum of three consecutive terms.

\section{Chapter Three:}

Terms of Reference of the Association's chairman and the board of management:

16) Chairman and members of the board of management should work voluntarily for the benefit of the Association for the period of one year.

17) Membership fees will be collected by members of the board of management and will be deposited in the bank account of the Association.

18) Chairman and members of the board of management shall distribute the available medicines proportionally amongst shareholders, according to the number of shares they hold.

19) Chairman and members of the board of management shall organize a minimum of two meetings per year in order to discuss proposals, recommendations, criticisms and in order to find solutions to problems.

20) Members of the board of management shall organize the annual general meeting under the guidance of the chairman of the Association to evaluate the activities of the Association and to take necessary actions and decisions for the further improvement of the overall affairs of the Association

\section{Chapter Four:}

\section{Rules for the sale of medicines:}

21) Purchase of medicines, vaccines and equipment in the first phase shall be carried out with the technical support of the FAO, Animal Health and Livestock Production Programme (AFG1931004) and technical clearance from FAO/AGAH.

22) Members of the Association shall follow good veterinary practices when storing, dispensing and selling veterinary remedies.

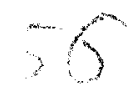


23) Members of the association will be required to purchase medicines as first priority from the Association unless supplies run out or specific medicines are not : available.

24) Medicines will be distributed to the Association's shareholders based on the value of their shares.

25) Income received from the sale of the medicines will be the assets of the shareholders.

26) The Association will charge a fee amounting to $5 \%$ of the local-landed cost of the medicines, vaccines, or equipment which shall benefit and support the Association. "Local-landed cost" will be calculated after delivery to each VSA at its Regional offices.

27) An additional marketing fee (suggested at $15 \%$ ) will te charged on the locallanded cost of the medicines, vaccines, or equipment to those veterinarians or paraveterinarians who are not members of Association.

28) Medicines or vaccines shall not be sold to persons who are not registered veterinarians, assistant veterinarians or paraveterinarians.

29) Damages and loss of medicines, vaccines, equipment from the regional VSA office will be born by the Association and its members.

\section{Chapter Five:}

\section{Association rules of procedure:}

30) Activities of the members of the Association for the benefit of the Association will be voluntary.

31) Members of the Association who do not follow the rules of procedure of the Association, or any subsequently agreed to rules of procedures, may forfeit any or all benefits provided by the Association.

32) A shareholder member of the Association has the right to leave the Association at any time and the unpaid balance of his/her share(s) will be repaid in full six months after written notification of intent to withdraw.

33) Rules of the Veterinary Services Association are prepared under five chapters and 33 articles and form a contract between the Association and its members.

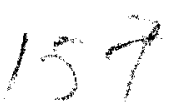


Member of the Association:

Name:

Clinic

Signature:

Date:
Association's Chairman:

Name:

Signature:

Date: 


\section{Proposal}

For better organization of activities related to supply and distribution of medicine, vaccines and veterinary equipment and execution of other related activities of the Veterinary Services Associations (VSA), an organization called the Umbrella for Coordination of Veterinary Services Associations (UVSA) shall be established to fulfil the responsibilities and obligations below.

\section{Responsibilities of UVSA}

1. UVSA will be considered as an umbrella for coordinating the regional VSAs.

2. UVSA will take the necessary action to procure medicines, vaccines, equipment and furniture for field offices of the VSAs.

3. UVSA will take on the logistical aspects of importing and distributing medicines and related veterinary items.

4. Upon receipt of medicines, UVSA will distribute them according to the number of paid-up shares held by members of the regional VSAs and transport them to the offices of the VSAs.

5. UVSA will purchase required furniture using funds from the FAO Livestock Production and Health Programme (AFG1931004) budgeted for this purpose.

6. UVSA will maintain and present proper documents against all expenses to FAO Livestock Production and Health Programme Office.

7. UVSA will receive receipts from VSAs for all payments made to each VSA and against delivery of medicines to each VSA member.

8. UVSA will present a written report to the FAO Livestock Programme Regional Office after each delivery to the field.

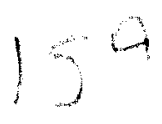


Date: 18.06 .1996

REPORT ON MISSION TO KUNAR PROVINCE OF AFGHANISTAN

Submitted by:

ACBAR Vet.Sub.Committee Appointed Technical Group

1. Dr.A.Osmani

2. Dr.M.A.Salemi

3. Dr.Dad Mohammad

4. Dr.Haji Malang

5. Dr.Shafiq
FAO Team leader

PRB Member

ADF

GAF

MADERA ",

Subject: To monitor and check the field efficacy of CCPP Auto vaccine produced and used by MADERA in Kunar province of Afghanistan

Date: $\quad 3.06 .96-10.06 .96$

Introduction:

Contagious Caprine Pleuro Pneumonia (CCPP) has known as an important disease of goats, and now it is a major cause of loss in goats population in different countries of Asia and Africa.The causal agent of classical acute CCPP is F38 biotype which is closely related to three other Caprine Mycoplasma pathogens, namely:

Mycoplasma mycoides sub sp.mycoides ( $\mathrm{Mmm}$ ) (The large colony type and this sub sp causes CCPP like disease in goats and sheep), Mycoplasma mycoides sub sp Capri (Mmc) which causes CCPP like disease in goats; and Mycoplasma Capricolum the main cause of Arthritis, Mastitis and Pheumonia in goats and sheep.

The disease produced by $(\mathrm{Mmm})$ and $(\mathrm{Mmc})$ resemble to that caused by F38 biotype in some aspects, and serological cross-reaction and similarity of reactions in biochemical test particularly between F38 biotype and M.Capricolum, can confuse the identification of the isolates.

Acute Pleuro Pneumonia in goats may also involve Pasteurella haemolytica and Pasteurella multocida. 
Two other Mycoplasma (Mycoplasma Ovipneumoniae and Mycoplasma Agalactiae) may be implicated in caprine respiratory disease which does not resemble to CCPP.

It was reported by MADERA to the ACBAR Vet. Coordination that since 1993 MADERA made an effort and produced CCPP auto vaccine from affected lungs of field cases of sheep and goats and used against to control the field disease outbreak in Kunar and Laghman provinces of A.fghanistan. In this regard they have succeeded to some extent to reduce the CCPP disease morbidity and mortality rates in the area.

\section{Activities:}

According to the prepared terms of reference, on 3.06.96 at 11.30 AM appointed mission proceed to MADERA head office Jalalabad city, after a short discussion with Dr.S.Tahir head of the MADERA Veterinary Sector, obtained related information regarding the starting date and quantity of CCPP auto vaccine produced and used. The starting date, total quantity produced and used in different districts/villages of Kunar and Laghman provinces, is shown in table(1).

Table(1): Date \& QTY of CCPP auto Vacc. produced and used by:MADERA

\begin{tabular}{|c|c|c|c|c|c|}
\hline NO & Date/Yr & QTY produc & QTY used & $\begin{array}{l}\text { sp of } \\
\text { animal } \\
\text { vaccinat }\end{array}$ & Area covered \\
\hline 1 & 1993 & $\begin{array}{l}90000 \\
\text { doses }\end{array}$ & $\begin{array}{l}60446 \\
\text { doses }\end{array}$ & $S p \& G t$ & $\begin{array}{l}\text { Kunar province } \\
\text { (Pashad,Want, Kan- } \\
\text { dy }\end{array}$ \\
\hline 2 & 1994 & $\begin{array}{r}93000 \\
\text { doses } \\
\end{array}$ & $\begin{array}{l}84809 \\
\text { doses }\end{array}$ & ", & $\begin{array}{l}\text { All the dist.of } \\
\text { Kunar province \& } \\
\text { Alishang\& Alingar } \\
\text { dist.of Laghman } \\
\text { province. }\end{array}$ \\
\hline 3 & 1995 & $\begin{array}{l}150300 \\
\text { doses }\end{array}$ & $\begin{array}{l}134946 \\
\text { doses } \\
28021\end{array}$ & $" \quad "$ & $\begin{array}{l}\text { All dist. of Kunar } \\
\text { province and most } \\
\text { of the district } \\
\text { of Laghman provin }\end{array}$ \\
\hline & Total & $\begin{array}{l}333300 \\
\text { doses }\end{array}$ & $\begin{array}{l}-403456 \\
\text { doses }\end{array}$ & & \\
\hline
\end{tabular}

In the same date at 2.25 PM with the company of Dr.S.Tahir mission left Jalalabad 'city for Kunar province and proceed to chowki district VFU at 5.25 PM and met Dr: Soorgul responsible vet for the VFU and other staffs. According to them and the VFU register from 15.12.95 - 20.12.95 they have vaccinated the goats of some villages of this district with MADERA produced CCPP auto vaccine and there was no any untoward reaction, 
they were satisfied with the field result of this vaccine.

Then we continued our trip toward Chaghasari and arrived there at 6.30 PM, we met the lab staffs and with the help of them and Dr.S.Tahir work plan was prepared.According to the work plan from 4.06.96-9.06.96 totally (20) villages of $(8)$ districts of Kunar province were monitored and (35) flock owners, vets, paravets and BVWs were interviewed for the field result of the mentioned vaccine, for detail see table (2).

During monitoring and asking questions from the owners and related technical staffs regarding vaccines, vaccination and the fieled result of different type of vaccine in general and MADERA produced CCPP auto vaccine in particular, generally we have faced with three type of live stock owners responses:

1. The first group owners, they were not able to respons the positive or negative result of vaccine and vaccination and the type of vaccine they were used through vets or paravet to their animals. Just they answered that vaccination is good for the prevention of the animal diseases.

2. The 2 nd type of flock owners responses were negative to the result of CCPP auto vaccine in some extend, according to Dr.Afzal (MD) from Kalai gal village of want district " three years back from one flock owner in Nishegrame village, he vaccinated his goats against CCPP, but after one month CCPP disease outbreak was started and most of his goats were dead.

In other instance, Abdul Qaium from Hazar Mir village of Chapadara was not satisfied with the result of CCPP auto vaccine, because he vaccinated his goats against CCPP disease and after some time, the disease outbreak was started with mortality.

In 3rd case, Dayium khan from Kumarigal village of Barikot district stated that, last year in February, 1995 he has vaccinated his 250 goats against CCPP disease, and during March - 95 the CCPP disease out break was started and $80 \%$ of his flock became sick, and 30 goats were dead, and most of the pregnant goats aborted.

In some other cases after injection of CCPP auto vaccine for four hours to one day reactions such as fever, anorexia, depression etc have been noted by flock owners.

3. The 3rd group of flock owners, were satisfied with the field re sult and efficacy of most animal vaccines, i.e, ASV, ETV, BQV, CCPP etc.

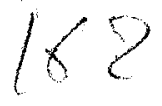


Ible (2): Districts/Villages covered and Flock owners interviewed during 04-06-96 to 08-06-96

\begin{tabular}{|c|c|c|c|c|c|c|c|}
\hline \begin{tabular}{c|c}
0. & 1 \\
- & 1
\end{tabular} & $\begin{array}{l}\text { Date } \\
\text { Interviewed }\end{array}$ & District & $\begin{array}{l}\text { Villages } \\
\text { Covered }\end{array}$ & Flock Owners Interviewed & $\begin{array}{l}\text { No. of } \\
\text { Goats \& } \\
\text { Sheep } \\
\end{array}$ & $\begin{array}{l}\text { Kind of Animal } \\
\text { infectious disease } \\
\text { they have faced }\end{array}$ & \begin{tabular}{|l|} 
Type of \\
vaccine they \\
used
\end{tabular} \\
\hline $\begin{array}{r}1 \\
-\end{array}$ & $4 / 6 / 96$ & $\begin{array}{l}\text { Ninglam } \\
\text { (Petch) }\end{array}$ & Waradish & $\begin{array}{l}\text { 1. Abdul Sayed } \\
\text { 2. Mola Jan } \\
\text { 3. Eqbal } \\
\end{array}$ & $\begin{array}{l}300 \text { Goats } \\
100 \text { Goats } \\
10 \text { Goats } \\
\end{array}$ & $\begin{array}{l}\text { Anthrax, ENT, } \\
\text { CCPP }\end{array}$ & $\begin{array}{l}\text { ASV, CCPP- } \\
\text { Vac, ETC }\end{array}$ \\
\hline $\begin{array}{r}2 \\
-\end{array}$ & $4 / 6 / 96$ & $\begin{array}{l}\text { Kandy } \\
\text { (Petch) }\end{array}$ & $\begin{array}{l}\text { Gulsalak } \\
\text { Sari Gal } \\
\text { Marchal }\end{array}$ & $\begin{array}{l}\text { 1. Wali Mohammad } \\
\text { 2. Sayed Ahmad } \\
\text { 1. Qadeer Khan } \\
\text { 1. Mir Azam } \\
\text { 2. Zaberdast }\end{array}$ & $\begin{array}{l}150 \text { Goats } \\
80 \text { Goats } \\
20 \text { Goats } \\
10 \text { Goats } \\
100 \text { Goats } \\
20 \text { Sheeps } \\
\end{array}$ & $\begin{array}{l}\text { Anthrax, Sp CCPP } \\
\text { FMD Agalactiae }\end{array}$ & $\begin{array}{l}\text { ASV, } \\
\text { Agalatiae } \\
\text { CCPP-Vac }\end{array}$ \\
\hline 3 & $5 / 6 / 96$ & Kandy & $\begin{array}{l}\text { Chapadara } \\
\text {-Hawara } \\
\text { - Hazrat Mir Kali } \\
\\
\text {-Kabori } \\
\text {-Sartoor Kali } \\
\end{array}$ & $\begin{array}{l}\text { 1. Karim Jan } \\
\text { 1. Sayed Mohammad } \\
\text { 2. Rahim Gul } \\
\text { 3. Nawab } \\
\text { 4. Abdul Qayum } \\
\text { 1. Mohammad Gul } \\
\text { 2. Amir Mohammad } \\
\text { 3. Ghazan Khan } \\
\text { 1. Barakat } \\
\end{array}$ & $\begin{array}{l}20 \text { Goats } \\
70 \text { Goats } \\
4 \text { Goats } \\
60 \text { Goats } \\
40 \text { Goats } \\
30 \text { Goats } \\
40 \text { Goats } \\
25 \text { Goats } \\
350 \text { Goats } \\
\end{array}$ & $\begin{array}{l}\text { Anth, ENT, CCPP } \\
\text { Agalactiae }\end{array}$ & $\begin{array}{l}\text { ASV, ETC } \\
\text { CCPP-Vac }\end{array}$ \\
\hline $\begin{array}{r}4 \\
-\end{array}$ & $6 / 6 / 96$ & Want & $\begin{array}{l}\text { Darar Waigal } \\
\text {-Kali Gal } \\
\text {-Kund Kali } \\
\text {-Want Kali }\end{array}$ & $\begin{array}{l}\text { 1. Shah Mohammad } \\
\text { 2. Haji Azizullah } \\
\text { 1. Mohammad Sher BWW } \\
\text { 1. Ghulam Sakhi } \\
\text { 2. Mohammad Jan } \\
\end{array}$ & $\begin{array}{l}60 \text { Goats } \\
300 \text { Goats } \\
- \\
40 \text { Goats } \\
100 \text { Goats } \\
\end{array}$ & $\begin{array}{l}\text { CCPP, Anth, ENT, } \\
\text { Listeriosis, } \\
\text { Agalactiae, FMD }\end{array}$ & $\begin{array}{l}\text { CCPP-Vac, } \\
\text { ASV, ETC }\end{array}$ \\
\hline 5 & $7 / 6 / 96$ & Shigal & $\begin{array}{l}\text { Shigal Center } \\
\text { VFU }\end{array}$ & $\begin{array}{l}\text { 1. Mohammad Yusuuf } \\
\text { Paravet }\end{array}$ & - & $\begin{array}{l}\text { CCPP, FMD, } \\
\text { Anthrax }\end{array}$ & $\begin{array}{l}\text { CCPP-Vac, } \\
\text { ASV } \\
\end{array}$ \\
\hline 6 & $7 / 6 / 96$ & Asmar & $\begin{array}{l}\text { Asmar Center } \\
\text { VFU }\end{array}$ & $\begin{array}{l}\text { 1. Dr. S.A. Sayedi } \\
\text { Responsibile VET, MVSc. } \\
\text { 2. Noor Hakim, Paravet } \\
\text { 3. Ahmadullah, Paravet }\end{array}$ & - & $\begin{array}{l}\text { Anthrax, ENT, } \\
\text { CCPP, BQ, HS }\end{array}$ & $\begin{array}{l}\text { CCPP-Vac, } \\
\text { ASV, ETC, } \\
\text { Agalactiae }\end{array}$ \\
\hline 7 & $7 / 6 / 96$ & Asmar & Enzer Kot & $\begin{array}{l}\text { 1. Sulton Mohd. } \\
\text { 2. Gul Amir } \\
\text { 3. Neshter } \\
\end{array}$ & $\begin{array}{l}6 \text { Goats } \\
60 \text { Goats } \\
3 \text { Goats } \\
\end{array}$ & $\begin{array}{l}\text { Anthrax, HS, } \\
\text { Agalactiae } \\
\text { CCPP, ORF, FMD } \\
\end{array}$ & $\begin{array}{l}\text { CCPP-VAC, } \\
\text { ASV, ETC, } \\
\text { Agalactiae } \\
\end{array}$ \\
\hline 8 & $7 / 6 / 96$ & $\begin{array}{l}\text { Dangam } \\
\text { Sub-Dist. }\end{array}$ & Dangam & $\begin{array}{l}\text { 1. Zeker Rahim } \\
\text { 2. Noor Mohammad } \\
\end{array}$ & $\begin{array}{l}120 \text { Goats } \\
300 \text { Goats }\end{array}$ & CCPP, ORF, SP & CCPP-Vac \\
\hline-9 & $8 / 6 / 96$ & Asmer & Nishagam & $\begin{array}{l}\text { 1. Shir Mohammad } \\
\text { Paravet in Kamdish } \\
\end{array}$ & - & $\begin{array}{l}\text { CCPP, SP, ENT, } \\
\text { Anthrax,Agalactiae }\end{array}$ & $\begin{array}{l}\text { CCPP, ETC, } \\
\text { ASV, } \\
\text { Agalactiae }\end{array}$ \\
\hline-10 & $8 / 6 / 96$ & Barikot & $\begin{array}{l}\text { Bari Kot center } \\
\text { Komarigal }\end{array}$ & $\begin{array}{l}\text { 1. Dr. Khan Rehman, Vet. } \\
\text { 2. Noor Rehman, Paravet } \\
\text { 1. Dayium Khan }\end{array}$ & $\begin{array}{c}- \\
- \\
250 \text { Goats } \\
50 \text { Sheeps }\end{array}$ & $\begin{array}{l}\text { Anthrax, ENT, } \\
\text { CCPP,Agalactia } \\
\text { SP, Goat-Pox, HS. }\end{array}$ & $\begin{array}{l}\text { CCPP-Vac, } \\
\text { ASV, ETC, } \\
\text { Agalactia }\end{array}$ \\
\hline
\end{tabular}


For example, Zaberdast from Marchal village of Kandy district, Haji Azizullah from kalaigal village of Want district and Noor Mohammad from Dangame sub district etc. According to them, they were experienced in animal husbandry and animal production, the importance of vaccine and vaccination particularly CCPP vaccine well known by them. During last three years they have used this CCPP auto vaccine and field efficacy of this vaccine was good with reducing morbidity and mortality rate of the
disease.

The field activity of MADERA VFUs staffs (Ninglam, Kandy, Want, Shegal, Asmar and Barikot districts) were monitored and the field efficacy of different type of vaccines especially CCPP auto vaccine were discussed. They were also satisfied with the field result of this vaccine.

According to Mohammad Sheer BVW from Kund Kali and Qiamuddin paravet from Kalai gal village, one - two years back they have collected CCPP disease suspected samples from Kund Kali and Nishegrame villages and submitted to MADERA Diagnostic lab in Chaghasari for investigation. The named lab staffs from those samples prepared CCPP auto vaccine and distributed to the area for use and the result of that was satisfactory.

Finally the mission visited the MADERA lab staffs (Mr. Nusrullah lab incharge and Najebullah lab member) and their diagnostic and CCPP auto vaccine production lab. The lab was equipped to some extent, but both diagnostic and vaccine producing lab equipment were placed in the same room. We advised them to separate the vaccine production lab equipment from diagnostic one, for precaution and contamination.

When we asked them regarding the date,reason and the procedure of CCPP auto vaccine production, Mr. Nusrullah lab incharge has responded:

- On 10.3.93 thére was an out break of unknown disease in sheep in Pashad district, he has purchased one sick sheep and transferred to MADERA HQ in Peshawar for disease diagnosis. He submitted the sheep carcass to the Veterinary Research Institute (VRI) Peshawar. According to the post mortem changes VRI Peshawar suggested that the case is pleuro pneumonia ( but there is no lab microscopic examination and confirmation. The lab result sheet of VRI Peshawar is attached). From the affected lungs they have prepared auto vaccine and showed to him, how to prepare CCPP auto vaccine. The prepared auto vaccine was handed over to him for use against the disease in the affected area. He distributed the 
prepared CCPP auto vaccine to the Pashad VFU staffs and by vaccination they have controlled the fieled out break.

- The second case was happened in Nishagrame village of DaraiWaigal in 1993. There was an outbreak of CCPP like disease in goats and they have purchased two sick goats and one of them was submitted to VRI Peshawar on 3.11.93 for diagnosis and confirmation. VRI Peshawar in accord to the post mortem changes suggested that is pleuro pneumonia ( but no lab microscopic examination and the lab result sheet is attached) and from the affected lungs they have prepared CCPP auto vaccine and gave him the vaccine to use for prevention of fieled disease out break.

That vaccine was already used by MADERA VFU staffs in the diseased area and the rate of morbidity and mortality reduced thereinafter.

According to Mr. Nasrullah lab incharge, every year he was following the same procedure and collecting the CCPP disease suspected fieled cases samples mostly during the early winter and preparing the auto vaccine and using freshly within two weeks time through a vaccination campaign by VFU staffs.

\section{Conclusion:}

From the result of interviews made with different flock owners, MADERA VFUs technical staffs, and the reduction of animal infectious/contagious diseases in general and CCPP disease in particular in Kunar province of Afghanistan we can justify that:

1. The auto vaccine produced and used against CCPP suspected fieled cases is effective to some extent and reduced the morbidity and mortality rates of CCPP suspected fieled cases. Actually it is a good effort of MADERA from economic point of view.

2. According to the said history by Mr. Nasrullah MADERA lab incharge, and no constant laboratory confirmation document it is difficult to say that only one sero type of Mycoplasmal particularly F38 biotype) or Pasteurella ? are involved with the field cases. Therefore it is suggested that, during CCPP disease suspected fieled out break and preparation of the auto vaccine proper sample should be sent to a standard lab ( probably to France) to identify and confirm the real causal agent(s) for further CCPP vaccine production and improvement.

3. Some negative points or un effectiveness of the said auto vaccine stated by flock owners are may be due to:

- Different field cases are due to different serotype of Mycoplasma.

- Short duration of immunity. 
- Un suitable transportation and usage by some vets,paravets and BVW.

- Unsuitable storage for long duration etc.

Anyway MADERA should find the source of such inability of the produced auto vaccine in the future.

4. According to Mr. Nasrullah lab incharge, during this auto vaccine production and distribution, out of three main tests namely: Purity/sterility test, safety test and potency test, he is performing only one test (purity/sterility test) by meant of culturing from affected lungs to the different media to differentiate the original from different invaders, eventhough this test is incomplete (because for the differentiation of Mycoplasma from Pasteurella he should add fresh blood of sheep into blood agar base,but he didn't.), of the other two tests, he is not doing any. Therefore, it is necessary for a vaccine producer to perform all the related tests, then he can distribute the product for fieled use. Safety and potency tests both are important, by any type of fieled trial. He can perform the safety and potency tests and he can estimate the duration of immunity produce.

Recommendation:

Providing different type of animal vaccines is one of the main and important part of animal health services in the country. The two lab technician of MADERA in Kunar province of Afghanistan have done an appreciable effort for the production of CCPP auto vaccine as their knowledge permit them. Their practical work is good but due to lack of technical knowledge in this field they failed to perform all related scientific tests. Therefore we hereby recommend, if it is possible for MADERA to train them in a standard vaccine production Institute to be more useful in this fieled for the future. It would be more useful if MADERA could appoint one qualified technical person to assist the lab staffs and if he could change the procedure for preparing of CCPP standard vaccine in that lab.lt would be more efficient for the control of CCPP disease throughout the country in general and for the south east zone in particular, for the future. 


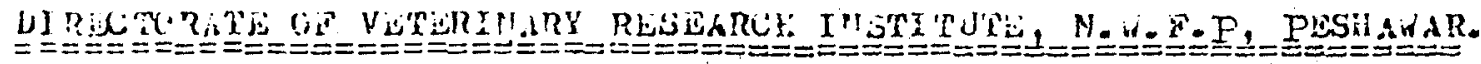

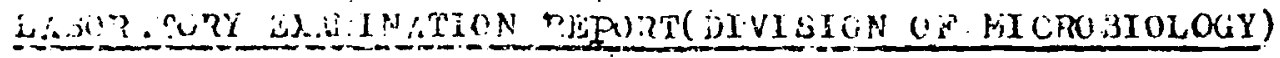

Rof your no. wated 10.3.93 Lab.No.554 Dated 10.3.93

$\ddot{r i n d}$ of Lab

ltetarial necicred.

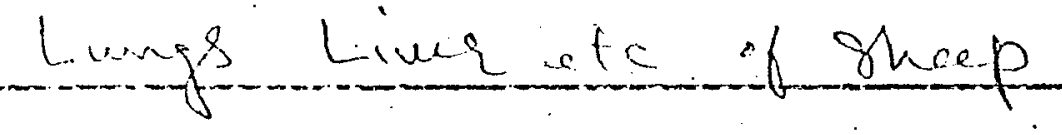

rom MADERA

axatinon for

Vail sad on recieved on

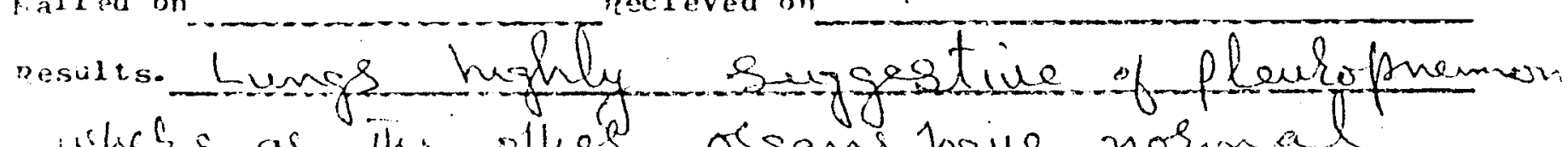

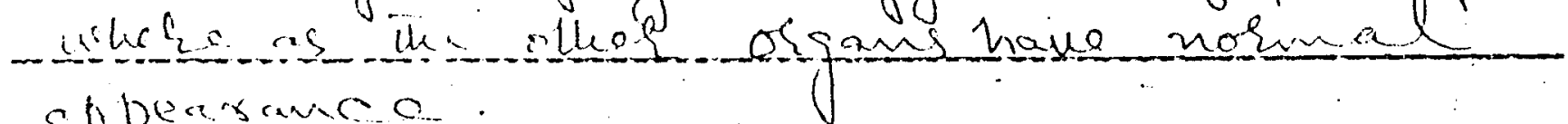

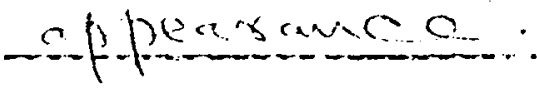

R:AnRs:

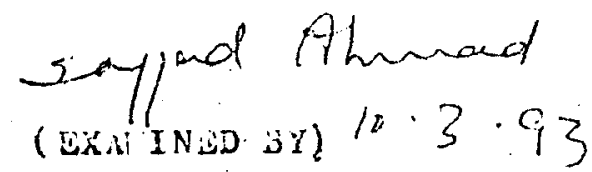




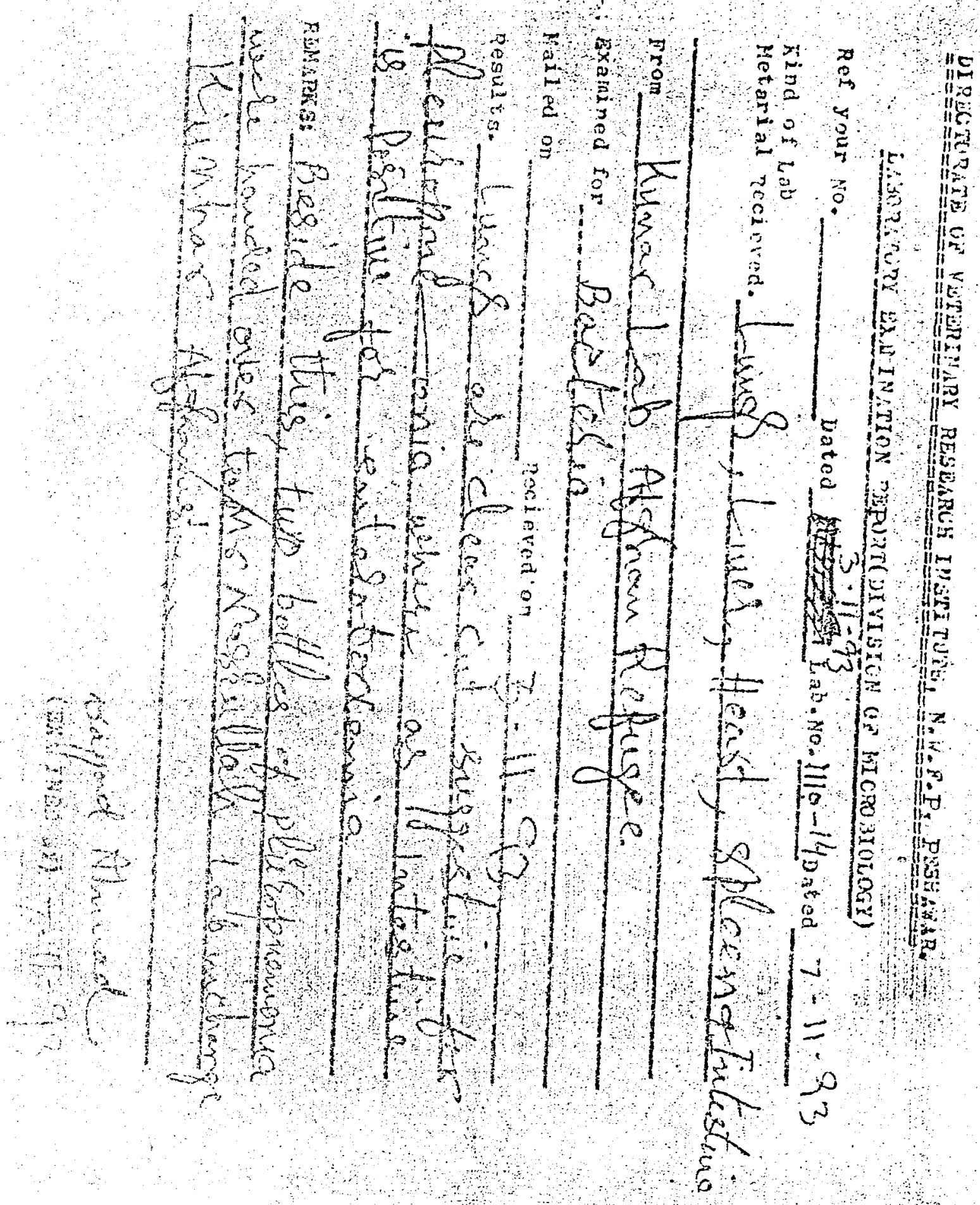




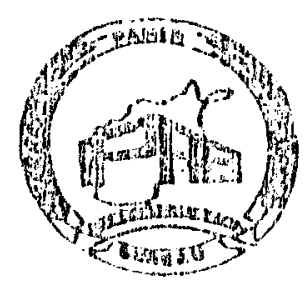

Parnir Reconstruction Propedi

\section{$(B P B)$}

Animal Hedth \& Livestord Production Department

Study on the frurinomal Aspoen of

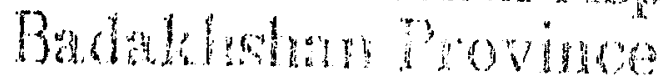

Ashoutetan

May, 1996

P awar, Pakistan . 
I. Gsnegal information:

Badaklishan province is situated in north-east remote part of Afghanistan, because of its distent location from the center ot this country ard absence of adequate roadr for transportation it has always been one of the backward provinces.

The geographical situation of the province js such that to the noth it is bound to the republic of Tajekestan, to the east to pakistan and the republic of people of china, to the south to the provinces of Konars and Laghman and to the west to Takhar province.

The altilude of Badathshar province from the sea level is about $960-2800$ meters, some parts like pamoer reaches up to $3000 \mathrm{~m}$ whol is alway covered by snow.

The majority of the population are Tajeks but a limited number of other tribes such as Uzbaks and Turkmans are also irhabitated there.

The center of the province is called faizabad previously it jovolved 6 districts, sub-districts where as now is increased to 23 districts.

Even before 1978 the country development plans were not applie? properly over there and during the wir since 1978 the previous condition is still continued. To improve the situation many international humanitarian organizations, UN agencies as well as some NGOS such as UNDCR, UHHCR, UNICEF, WFP, WHO, Afghan Aid, NAC, SCA, and PRB have started/completed their rehabji.jation and reconstruction procrans and project covering aifferent parts of the province.

The total area of the province is approximately $41.490 \mathrm{~km} 2$ that involves totaljy 3000 viljages with 00667 familiss existing, during 1990 the total population in the province was estimated around 554370 people.

For better understanding anc to study the different aspects of areas the province is divided into 2 major parts on district basis.

A. The southern district of:

Jurm, Baharak, Faizabad, Gandum Ghul, Kishim 
Darwaz, Sheghman, Shahere-bozurg, Khawahan, Ragh, Ishkashim, wakhan, zibak.

Tite uibirict located in souhern part covers the areas where mostiy poppy is cultivated. ls mentioned above many organization have implemented some appreciable work of thiex concern incluaing rep.

The southern dirtoict have compatively better food production but the cost is very high Monwhile thewe are some roads present but in a very bac condition, another main problem of this region $i s$ the occiurrence of flocd ouring the spring and sumer season, 25 well as soil erosions with the destruation of forests. The considerable problem of the not thein distudot: are majilly:

1. Absene or roase and ways for transportation.

2. Wost of the tame is min-ped (not jursetable).

3. Agricultural products are of very minor quantity.

It is also to be mentioned that the perple belong to this region do not cultivate the poppy but they are used to utilize the opium.

PRB monitoring obsewation shows the socio-economic problems of the people in north is more than that of the southern districts because the distance in between districts js very far meanwile there are no road or any mechanical transportation facilitics, agricultural products are insufficient, there is mon higher rate of malnutrition in children as well as in adults. It is also very sad to say that majority of population are used to opium.

There j.s a lot number of different domestic and wild animals but because of long winter and less feeding stuff the level of productivity is very low, veterinary services centers are not. established. Preverition of animals against various infectious diseases requixes more attention as the vaccines provided to PRB VFUs is not sufficient to reach the northern districts, more quantity of veterinary vaccines to be issued by the donor concerned.

Generally speaking the northern districts of Badakhshan need more attention of international donors for wocio-economic development.

Agricultural products of Badakhshan are mostly wheat, oats, corn, potatoes, paddy, legumes and other vegetables and fruits, which are not enough to cover the need of the population. 
The industrial products of bidathshin are carpets, Rugs, Jenthes products, Woolen pieces mollandicrasts but are all in insufficient quantity.

The natural wesoluces of the province inciudes forests, precious stones, gojd, iron, copper, salt, etc unfortunately they are still in an original posjtior and the resolurces have not been so far utijized.

Most of the schools are running actively, the number of educated and literated people in Badakhshan is more than any other province in the country. Specially the women have been educated in a considerable number who are now localized in there native places after finishing education in Kabul etc.

T.T. proquctive notential of Badahohan province:

Badakhshan is a mountainous area, although there are many rivers providing an adequate cuantity of running water but because of rioher level of arable land as compare to the low level. of running water, mostiy the water of these rivers are not suitable to be utilized for irrjgatjng cultivating land, therefore the major parts of the area available for agriculture is rain-fed land which depends on the seasonal. rainfall. It is also worth to mention that the higher price of fertilizer has no affect on the productivity of land.

The available area suitable for agriculture is very limited in Badakhshan province where as the land ownership ranges from 515 jeribs (1-3 hectares). Natural disasters like flood, drought, earthquakes, soil exosions etc has also an adverse effect on the production.

Total area of Badakhshan province cover $41490 \mathrm{~km} 2$ of which 905 $\mathrm{km} 2$ is forest, $2927 \mathrm{~km} 2$ is pasture, $1821 \mathrm{~km} 2$ is estimated to be suitable for the cultivation of agricultural products as well as vegetable and fruits. The remaining $35341 \mathrm{~km} 2$ is not utilizable for agricultural purposes as ve calculate on percentage basis it will show that $2.17 \%$ is forest, $7 \%$ is pasture, $13.6 \%$ is sujtable for cultivation of other crops,and fruits ete and $36.38 \%$ is waste land.

Compare to existing population in the area agricultural land is very little and by no means they could be self sufficient.

During 1976 UNDP/FAO had given a warning of food shortage in Badakhshan, even now the local production will be onough only for $1 / 3$ of the population, an other 2/3 portion is purchased from markets. According to available information only about $20 \%$ population is self sufficient the rest of them that is $80 \%$ usually purchased their required food stuff. Out of $1 / 3$ of self sufficient farmers, approximately $12 \%$ of their excess products is marketable. Usually the commodity required for consumption is transported from far distant villages carried by horses or donkeys covering days journey to be transported. 
III. Socio-eonnomic stuntion:

Nutritional status of food stuff which is the prodnct of

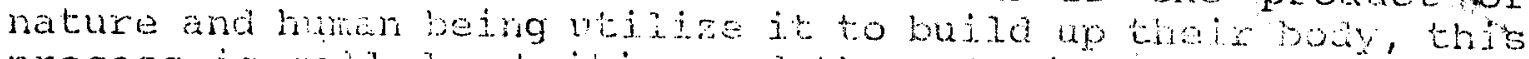
process is called rutribion and the naterials wed ia called food. food is usually either rom plants om anjmal sources otherwise on chemica] basis it covta also be divided on

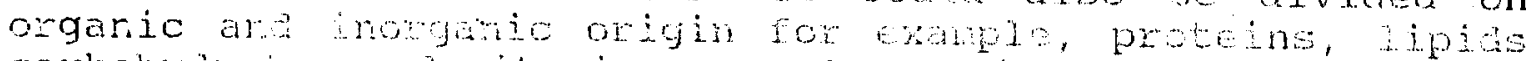
carbohydrates and vitamins ate of organio, water and mineral are or inorganic origin.

Adequate mutrition je a ghantidatvely and owaibatively

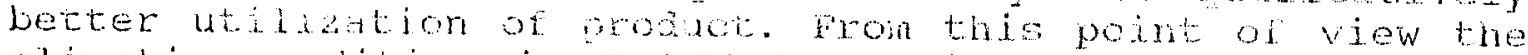
clinatio condition in Gadabionan being cold ard the aroa mountainous, laving very little cultivated land compare to the

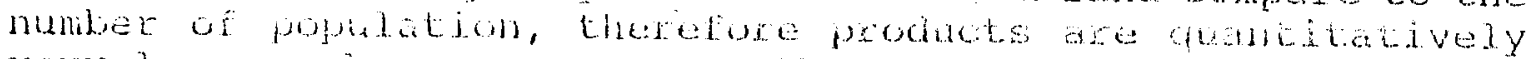
very less, and cur never cover the need for better nutrition.

The estinated statistic of the year 1967 in Banahohen shows the following anoun of food stutt an kgs for each family in one year.

\begin{tabular}{|c|c|c|c|c|c|c|}
\hline $\begin{array}{l}\text { Wo of persons } \\
\text { in one family }\end{array}$ & Adults & onilduen & H!neat & cexeals & $\begin{array}{l}\text { cooking } \\
\text { oit. }\end{array}$ & lotatoes \\
\hline 12 & 8 & 4 & 500 & 240 & 80 & 640 \\
\hline
\end{tabular}

Nowadays for each person in a family in one year it is calculated $a s$ weat $=66.99$, cereal $=20 \mathrm{~kg}$, cooking oils $6.6 \mathrm{~kg}$, potatoes $=53 \mathrm{~kg}$ mere as if we calculats it for one day conseguentiy it: wifl be 300 grams 54.47 grams, 16.43 grams, and potatoss 145 gams.

These estimated products will be able to produce aproximately 2300 calorites, this anount of energy produced will be too little because a person who works fox 8 hours a day 3000 alorie is required of which $1 \% 00$ galories wijl be utilized for Basal Metabolism of the 300 calowies for total metabolism or activity metabolism. Shortage of calorie and exercising the routine activity which nostly forcibiy to be done to maintain existence wold lead for the utilization of body composition such as lipids, Carbohychates and proteins. Whis conditions now very much applicable to Badakhshan people that majority of the adults uses their bory composition for the production of energy to work and therefore they are naturally getting lean, their working capacity reduces and looses resistarce againot many disease, lost the average range of 1 ife tn such environment will be low with very high mortality rate. In general the outcome of such food shortage will cause malnutrition. In this regard UNICEF has given warning of inalfutrition in children of Badakhshan during 1992 and shown the incidence of mortality 40-50 person/1.000 persons with the extreme ratadi110,1000 person. 
It is a considerable point that nothing have nentioned about animal prodicte in badahinan, atchough a huge number of animas due given in statistiss. hodording to estinated statistics in 1967 the collowing numer of animals are
conted:

\begin{tabular}{|c|c|c|c|c|c|c|c|c|c|}
\hline $\begin{array}{l}\text { Human } \\
\text { population }\end{array}$ & $\begin{array}{l}\text { Arclinary } \\
\text { sheep }\end{array}$ & $\begin{array}{l}\text { kisragul } \\
\text { shoep }\end{array}$ & Goats & Lattle & Eurfaloes & Cane! & Horse & bonter & Posltery \\
\hline 4861830 & 337770 & 2150 & 253210 & 173050 & 1090 & 760 & 21160 & 57310 & 220750 \\
\hline
\end{tabular}

The Panir Recomstruetion Ruren has sstabished three veterinary clinics in the distrjots of Feizabad, Brharak ard Kishim since 1904 , the animals haal count is performed during 1994 by vru personnel the following numbers are recorded.

\begin{tabular}{|c|c|c|c|c|c|c|c|}
\hline & $\begin{array}{l}\text { Eopula } \\
\text { Eion }\end{array}$ & Catt 10 & Shaep & Gcotas & Hortse & Donkey & Poultry \\
\hline Faizabad & 47020 & 24010 & 67048 & 30767 & 818 & 6163 & 29869 \\
\hline Kishim & 19630 & 15483 & 20606 & 27715 & 710 & 5149 & 33518 \\
\hline Baharak & 1.4800 & 14000 & 251966 & 155596 & 1269 & 8112 & 35208 \\
\hline
\end{tabular}

Information based on personal communication states that a high number of anjmals in Baharak district inciudes those migrating animals who are moved place to place via Baharak in search of pasture during different seasons.

Since 1952 United Wations discuss the mater of food shortage and hunger in thejr annal sessions, all the menber countries knows that $2 / 3$ of the world population cannot receive the adequate food for their xoutine utilization, meanwhile it is also understood that most of he countries in Asia, Africa and South America are faced to such problems, although the natural vesources in those countries are suitable for economic improments but unavailablity of proper technology and E. r radaj possibilities the resources are not so for put into

c. a initut.

ons thought of increasing the probuctivity, where as :iric studies, i] lustrated that the increase in procuctivity lot parallel. to the increase in population rate as their is h Increase in amnal population compare to increase in al roductivity in terms of oet capita consmpton. liy there are 2 factor involved in the increase of
ulation.

Development of medical science by using effective medicines against total disease as well as successful prophylactic measures by using vacoines agajnst many 
Prof. Samuel Brandy (1954) has explained the danger of population increase severe than that of cancer and draws the attention of nations to think of their future existence circumstances.

When we talk of adequate food it is the food of animal origin which is important in the development of body structure and mental health, keeping working capacity, resistance of body against many diseases etc. These food stuff includes meat,
milk, egg and there products.

statistical information fxom FAO shows the world is suffering from the shortage of above products, the results collected from research sources and its analysis shows that the routine requirement for adult humar body is $35 \mathrm{gr}$ protein from animal origin, FAO concerned reports also states that as an average each person receives only 27 gr of animal originated protein on worldwide basis, going into more details developed countries 44 gram, developing and undeveloped countries as an average of less than $10 \mathrm{gram} / \mathrm{day} / \mathrm{capita}$.

During 1967 this range in Afghanistan was accepted to be 14 gram and in Turkey it is said to be 17 gr/day/capita. In Pakistan annual meat production is 2 million MT and milk is 13.8 MMT, therefore as if the population is accepted to be around $120 \mathrm{million}$ per capita protein consumption/day will reach to more than 25 gram from meat and milk only.

Proteins are made of Amino-acids, the number of these amino acids in the composition of different proteins reaches 25 , of which 10 of them comes from animal proteins that is necessary body. These are called essential amino acids, meanly taken from meat, milk and eggs.

If we compare the rate of production and consumption of food stuff, it is estimated that the rate of increase in human population is calculated 2.2 - $21.7 \%$ where the rate of increase in food materials in the world is only about $1 \%$.

IV. Analysis of the situation of shortage of food in Badakhshan:

Based on literature available agricultural and livestock production in Badakhshan is too less compare to the density of population. This may be because of different factors such as:

A. Number of population:

Unifortunately till now there is no assured statistical data bf population in Afghanistan, this will definitely have a negative afect on the implementation of socioeconomic development planning program of the country. 

There ale cifferent data available about the number of
populatior in Badakhshan for example:

1. The data from the ministry of planning afiairs in

2. Ministry of statisticsers.

3. DPA 1936 of statistics states it 592000.

4. UNDP/OPS/Untioned 497758.

UNDP/OPS/UNOCHA 1992 published 554370.

B. Available land suitable for cultivation:

Badakhshan is a mountainous area agricultural land is too little. total available land of the province is said to be around 450000 hectares of which 192000 hectares is under cultivation that $42.7 \%$ of the total land is cultivable, Out of $42.7 \%$ agricultural land $17.18 \%$ is known that 6658 and $82.8 \%$ is rain-fed land. It is also 96000 hectares hectares land is for horticulture, over pasture (operation SALAM-1989). 122000 hectares is

C. The insufficient agricul wheat, barely (oats) varieties of vegetables an, legumes, paddy, potatoes,

D. Badakhshan has very natural resources like precious stones, copper, lead, salt, gold etc but not yet
utilized.

E. Quantitative evaiuation of agricultural products based on data available during 1978 the product for each one jerib Iand calculated is $266 \mathrm{~kg}$ that is $1330 \mathrm{~kg}$ for each
hectares from irrigated land.

Therefore from one side less area of cultivable land and from other side lesser product per unit area of land in compare province.

Available information states that even before the war period $50 \%$ self sufficiency of the agricultural products was speculated; this got worst during war and still continues.

V. Reasons for reduced productivity:

1. Although Badakhshan has a lot of water resources, unfortunately the rivers level is to low than that of land, mechanical facilities are not available to make use of water, therefore major portion of the cultivable land cannot be irrigated.

2. Incidence of animal and plant diseases, as well as locust causes loss of productivity, shortage of improved seeds and fertilizers can also be a reason for economic
backward'ness. 
3. About $80 \%$ of Badajhshan's population is busy with agriculture which involves 443499 people for each person 0.432 hectares land will be rvailable for cultivation. including both irricyated and rain-fed land.

4. Cultivable land is cultivated every altenative year because of the unavailability of enough water for irrigation as well as fertilizer, once again recuces $50 \%$ of the annual productivity.

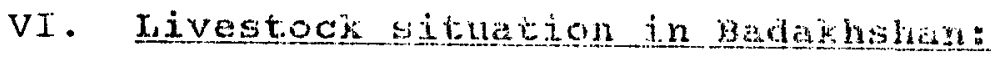

There is no definite data of livestock census of Badakhshan, different sources gives different information. One could see that there are guite a lot number of livestock in he province but there is diflicult wjuter feed, that is why the animals are mostly raised for marketing purposes, it is a dso observed that even the productive animals are moved into a distant pasture at sumier time aid chere will be no chance of the consumption of their products like milk by the fanjlies. Soon after the animals are grown up they will be sold in market to get money and provide their reguired food sturt and other needed materials. Therefore their is deficiency of protein in their food, the population will face to the danger of the occurrence of various ratal diseases because of their low body resistance. Sub normal physical and mental development in children, reduced working capacity in adults as well as high rate of mortality in children as a result of mall-nutritive food there is chance of occurrence of some infectious diseases for example Tuberculosis as reported oftenly all over the province as a prevalent disease in human being.

It is worth mention that as a result of low economic level of Badakhshan society alorig with possibly less utilization of meat and milk the best source of protein would the poultry mat and eggs which is not enough to cover the body requirement for protein by the last two items only.

Because of the absence of roads and properly connected ways between different districts and villages approach to socioeconomic affair is difficult, even though many international NGOs and orgarizations have tried their best for their projects implementation in various fields with good results but as said constraints present as environmental affects, it atill require much more efforts to improve the situation to a poszible extent.

According, to the technical field reports received fom our vru areas in Faizabad, Baharak and Kishim.district, various infectious and non-infectious disease of animals are noticed tó be present as endemic disease occurring sporadically in different seasons of the year. Such as:

1. In catto: Anthra, FMD, BQ, HS, TB, Mastitis etc. 
2. [n sheep and goats: Anthrax, Enterotoxemia, sheep and goat pox, Eot rott, lllo, lls, etc.

3. In poutty: Now castie disease CRD, Pox, etc.

linese only 3 vet.clinics will not be able to cover ali la aisiricts services unless tos number is increased.

VTT. Recommendation:

1. Based on FAO policy on Animal Health and Livestock Production Pxogram establishment of 10 other vet.clinics by PRB beside previous established 3 clinics to cover all 13 districts in consideration to geographical situation as recommended in 1995.

2. Establishment of livestock improvement activities by implementation of AI/inbreeding programs.

3. Extending extension services and providing informal education to faxmers and animal owners about animal hedith, production and management.

4. Provision of Apiculture program and managing short term training programs in continuation of some work done by. Afghanaid in this fiela.

5. Provision of sericulture training and developing program and its distribution.

6. Provision of women BVW (Basic Vetexinary Worker) program under women development program.

7. Provision of preventive measures for wild life such as yak.

8. Provision of Horticulture development program.

9. Provision of vocational training program to improve skjll efficiency for self sustainable program.

10. Provision of training courses through skilled local women to improve and increase handicraft production under women development program.

11. Proviston of emergency programs to overcome the problem of malnutrition.

12. Provision of infrastructure and public utility building.

13: Providion of initiatirig and supporting poultry farming ant raising program specially under women development program . 
14. Replanting of trees and forestry developing program specially with trees having leaves eatable to animals.

15. Construction and reconstruction of roads between districts and main villages and Takhar province to financial assistance of internation and products with the organizations.

16. Provision ol reforestation to avoide soil efosions. 
Date: $\mathbf{3 1 . 0 3 . 9 6}$

\section{TERMS OF REFERENCE FOR THE WORK GROUP TO CHECK THE EFFECTIVENESS OF CCPP VACCINE PRODUCED BY MADERA IN KUNAR PROVINCE OF AFGHANISTAN}

Contagious Caprin Pleuro Pneumonia (CCPP) is a highly contagious disease of goats which is endemic in most part of Asia and Africa. Two sero type (Mycoplasma Mycoides sub.sp.Capri and Mycoplasma - f38) have been found to be responsible for the disease out breaks.

Because of no laboratory disease diagnosis confirmation for different sero types of the causal agent in Afghanistan it is difficult to identify the sero type prevalent in Afghanistan.Based on this fact it is impossible to recommend a CCPP vaccine for Afghanistan. Therefore MADERA made an effort and produced Auto vaccine and inoculated 100,000 goats.

According to MADERA reported in ACBAR vety sub committee meeting the vaccine was effective in controlling the disease in Kunar province.In order to find out the quality and efficacy of the vaccine, Laboratory capacity and the procedures to be tested and the area vaccinated should be monitored.

Since the vaccine is produced by the MADERA lab only in October and November, it was suggested that monitoring of the lab will be carried out in October and November.It was recommended that a group of experienced vets from different NGOS involved in veterinary activities in the region including FAO and MADERA will monitor the area vaccinated in October - November 1995 and find out whether the vaccine practically prevented the disease.

Therefore the technical working group which was appointed by ACBAR vety sub.committee on 12.03 .96 will be :

$\begin{array}{lrl}\text { Dr.A.Osmani, } & \text { FAO } & \text { Team leader } \\ \text { Dr.A.Salemi, } & \text { PRB } & \text { Member } \\ \text { Dr.Dad Mohammed, ADF } & \text { Member } \\ \text { Dr.Haji Malang, } & \text { GAF } & \text { Member Di } \\ \text { Dr.Shafiq, } & \text { MADERA } & \text { Member }\end{array}$

The following terms of reference are prepared for the technical working group to monitor the field results of the CCPP vaccine produced and used by MADERA: 
1- At first list of flock owners in 5-10 different villages of 2-3 districts which were vaccinated against CCPP should be collected from MADERA regional office and VFUS
for checking.

2-Interview with different farmers/flock owners of different villages of 2-3 districts through asking the following questionnaire by using PRA methods:

- What type of animal they are keeping and their herd/flock size?

- What is their main problem in animal health and livestock production at past and - What type of animal disease (local name) they have observed in their flocks during
last three year?

- What was the main clinical signs and duration of the observed disease?

- What was the morbidity and mortality rate of the disease they have faced in their

- In which season of the year animal disease would be prevalent?

- Is there any local procedure for animal disease prevention and control in the past or

- Are they vaccinating their animals against infectious/contagious disease every year? What season is the best time of vaccination?

- When they are leaving the village for summer pasture and returning back?

- What type of vaccine they have used in the past and what was the results?

- Do they know the type of vaccine they have used in the past or they are using now?

- From which vaccine they have got satisfactory results?

- Which agency is working for their animal health services?

3- Finally the collected information should be analyzed and the res submitted to ACBAR vety sub committee meeting for action.

Time for this Helssion should be one week and vehicle for transportation shoutd be
provide by MADERA.

The checking of laboratory condition and the procedures they are following for the production of CCPP vaccine we have to wait till November and December (the time of producing vaccine) and for that purpose following points should be checked:

- 1- How they are Isolating and harvesting the causal agent from field cases?

- 2- Are they sure that the causal agent they have collected is mycoplasma?

3- What procedures they are following?

4- Do they perform all the vaccine,s production related tests such as: Purity(sterility), safety and potency tests?

5- What is the procedure for maintenance of virulent in stock culture?

6 - How long they can store the produced vaccine in laboratory and field condition from manufacturing date?

7- What is the procedure for estimating the shelf life of the vaccine?

8- Do they have under taken any field trial to know the effectiveness of the vaccine, if the answer is no, how they can say the immunity duration for this vaccine is one 
year?

9- If documentary information is not sufficient to justify, then mission will under take a field trial by meant of using the vaccine on (10) goats of some owners as a test flock and (10) goats as a control.Blood serum should be drown on (0) day and 14 days after vaccination for antibody titre against the CCPP disease through a standard lab which admission should be taken in advance.After obtaining the result final report should be prepared by appointed work group and submit to the ACBAR vety sub committee for further action.

$$
\begin{aligned}
& \text { Nov. } \quad \text { Dec. } \\
& \text { 82 }
\end{aligned}
$$




\section{$\begin{array}{lllll}\mathbf{A} & \mathbf{C} & \mathbf{B} & \mathbf{A} & \mathbf{R}\end{array}$ \\ VETERINARY SUB-COMMITTEE MEETING \\ 10 January, 1995}

\section{By Naqib A. Noory}

Approval of agenda and the minutes of the last meeting The minutes and agenda of the meeting were approved.

DCA's BVW Manuals, Dari version will be ready by the end of January, while the pushto version may take another month.

I. Announcements

ACBAR announced that Mrs. Margaret Reid has joined ACBAR as Personal Assistant to the Executive Director and Programme officer, as of January 1st, 1995. She will be working in the various ACBAR coordination and technical sub-committees.

The chairman welcomed Mrs. Margaret and hoped that she may further strengthen coordination among the NGOs and the various committees of ACBAR, and promised her every possible assistance.

DCA announced that Dr. Garet wassink will be joining them, as DCA's Director for the second time.

The chairman asked MADERA if there was any progress with the establishment of the proposed vaccine production laboratory.

MADERA, in response, said that they have had meetings with an institution in France, who may shortly send a team to carry out the feasibility survey in Jalalabad, the site proposed for the vaccine production facility. Upon completion of this process, MADERA will
consider the recommendations of the team.

[II. Take over issue of Malistan and Jaghori Clinics

FAO reported that the clinics have already been negotiated and handed over to MCI before the last veterinary sub committee meeting. Funds for 1995 have also already been allocated.

Based on the discussion in the last veterinary meeting, NGos felt that FAO's decision of handing over the clinics to MCI is not according to the regionalization of activities and therefore, requested FAO to reconsider the issue.

FAO responded that new NGOs could not be included in the programme, MCI was an NGO who had some other activities in the region, and had veterinary projects with UNDP/OPS in the south-west in past years. FAO advised they will closely monitor MCI's VFUs in Jaghori and Malistan.

IV. New Programme for 1995

FAO distributed Policy Paper "Discussion on New CSAs 1195" and "Discussion on New VFUs" to participants, and elaborated on the contents of the paper. FAO added that the paper is aimed at achieving the goal of privatization, efficiency and sustainability. Many of the elements of the paper are already in practice and the field staff are aware of these. 
MADERA inquired if FAO had completed any study inside Afghanistan of areas and conditions of the farmers, before resorting to speedy changes under the name of sustainability. The policy which FAO is intending to push seems inappropriate in Afghanistan, as the situation is one of an emergency nature in most parts of the country. MADERA advised that NGOs follow the policy of privatization gradually when the situation is ready for a change. Regarding the vaccination campaign, there will be no charges to the farmers from MADERA at all. MADERA asked if FAO can name any country in the world with a situation like Afghanistan, where a policy such as FOA is intending to implement, has been adopted.

FAO in response said that they have had trips to Khost, Gardez, Wardak, Ghazni and the northern areas of Afghanistan, and have discussed the scope of the programme with farmers. The suggestions made by farmers have been taken into consideration.

FAO elucidated that there are some 81 districts in Afghanistan which are not so far covered by any NGO and do not have any vet. services and asked that should the farmers just sit and let their animals die? FAO thinks that people are ready to pay for services and asked, what would happen if no money is granted to the programme, should the programme also come to an end? In the way FAO intends to operate, there will be at least $50 \%$ continuity of the programme, and Afghans have to become self reliant.

MADERA supported the vaccination campaign system and emphasized that the neglected villages and remote villages within the district should be reached by the immunization campaign. Medicines should be sold at subsidized prices as in some areas farmers may not be able to afford $100 \%$ of the cost, or even less. Timely delivery of vaccines to the VFUs is very important for the vaccination campaign.

FAO agreed that there were difficulties with the vaccine supply system in 1994 partly due to the transfer of the programme from UNDP/OPS to FAO, and hoped that in the future the vaccines will reach the VFUs on time.

Regarding full payment for medicines and the privatization process, FAO stated that funding is likely to come to an end by 1996 - vaccination campaigns need the support of the Government, and extra funds in the present circumstances may not materialize.

PRB supports the idea of vaccination campaigns - and quoted the example of vaccination campaigns prior to the war. They also stressed the necessity for the timely supply of vaccines.

GRSP said there should be a better mechanism in order to make the programme sustainable. If the veterinarians are provided with medicines, they: will just become shopkeepers to sell their medicines, and be paid for it. Besides, many people still cannot afford to pay for medicines in Afghanistan.

DCA based their survey in some 40 districts, where the average land owner owns 1 - 10 jeribs of land, and also said that the veterinary structure in the past was not effective - it lacked awareness among the community and it seems that everything comes from the top - there should be motivation, not pushing the policies. 
It was reported that the privatization process has been under way in the past 2 years, there is serious communication gap between farmers and the field staff.

FAO agreed to the points raised.

MADERA inquired if NGOs were able to work in a combined fashion during the vaccination campaigns, and if MADERA would get vaccines which they will need during this exercise.

\section{Discussion Paper 2}

The paper was read and elaborated on by FAO.

DCA in general agreed to the contents of the paper and said that it is a possible way to go. As stated before, there is a need to take into account the awareness of farmers, otherwise just pushing the policy may not work.

Regarding $B V W$ and extension training, DCA said that funds seems to be insufficient, NGOs may not be able to conduct such training.

DCA again stressed on intense and qualified monitoring.

MADERA added that external monitoring could be conducted through ACBAR as the NGOs are members of ACBAR.

ACBAR clarified that with the addition of the swedish committee Agriculture Survey Unit, ACBAR would be able to conduct monitoring exercises - provided that it is financed, as ACBAR may not be able to give such support with the current funding situation.

FAO in reply said that NGOs financed by FAO are accountable to FAO and FAO is accountable to the donors. Monitoring has to be done by FAO, any external monitoring will also be welcomed. FAO will enhance monitoring and evaluation through conducting courses, and more emphasis would be given to improve the services, rather than to police the NGOs.

Regarding extension training, DCA said that the graduates of the extension department of agriculture faculty, might be suitable to recruit.

FAO felt they would recruit agronomists, who might have completed extension courses, and train them in Animal Husbandry.

The chairman added that the selection of qualified monitoring and extension staff will result in a better quality of services to farmers, and suggested that graduates with good qualifications in Animal science should be the first choice for this selection.

After a lengthy discussion, it was agreed that the graduates of animal sciences should be recruited as extensionists by the implementing NGos. It was proposed that the issue be discussed in the light of activities to be undertaken, and the expertise of the personnel involved.

Having no o,ther issues for discussion, the meeting was adjourned.

The Next Veterinary meeting will be held on February 14th, at 09:00 hrs at the ACBAR office.

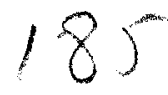


v. Any other business None

\section{- Participants:}

- Dr. Hussaini Chairman

GAF

- Dr. Tino Henecken

- Dr. Rahmatullah

- Dr. A. Ghafoor

- Hamidullah Natiq

- Dr. M. S. Tahir

- M. Khalid Rasheed

- Eng. Mohd Kabir

- Dr. T.J. Barker

- Dr. Nazim

- Morsal

- Margaret Reid
DCA

DCA

GAF

AAD

MADERA

ADF

PRB

FAO

ARR

RAFA

ACBAR
- Eng. Esmat

- Dr. A. Q. Samsoor

- Dr. M. Halimi

- Dr. Ataullah

- Dr. JF Cautain

- Dr. Amber Gul

- Dr. M. Kazem

- Dr. Mehraban

- Noor Agha

- Ajmal Sherzai

- Naqib Ahmed Noory
ADA DCA DCA GAF MADERA ADF PRB FAO GRSP APA ACBAR 


\title{
VETERINARY SUB-COMMITTEE MEETING \\ HELD ON \\ February 14, 1995
}

\author{
By Naqib A. Noory
}

I. Approval of minutes of the last meeting

The minutes of the last meeting were approved.

gearit

The chairman welcomed Dr. Gaxet Wassink, Director DCA for his second term as the Director of DCA and thanked him for his contribution in the past with the veterinary sub-committee.

Further to the minutes of the last meeting, following clarifications were asked:-

Dr. Garet Wassink inquired about FAO's funding situation as stated in the minutes of the last meeting.

FAO said that it is not clear from UNDP and do not exactly what will be the funding situation beyond 1996, present scenario is for severe shortage of funds for this sector.

DCA inquired about the fate of NGOs at the end of 96 when funds stop whether their role will diminish or they will be transformed to institutional entities? since good work could be achieved through NGOs at the given circumstances, NGOs with good reputation will exist and will work in the future programmes.

FAO expressed concern about NGOS not complying with the FAO policy aimed at sustainability of the veterinary services might create difficulties. Continuation of war in Afghanistan and the lack of interest of donors, FAo thinks that the programme should be made sustainable. If peace comes, the work will be handed over to the Ministry of Agriculture.

DCA inquired about the role of NGOs at that time.

FAO said that there is a need for careful thought, the future can not be predicted, NGOs may probably have place in the future set up.

\section{Announcements}

PRB annqunced that it will have difficulties with take over of Dila VFU of Urgun and asked if DCA could. change Dila for Naka of the same province.

- The chairman in reply said that much discussion took place among concerned NGOs prior to the assignment of take over of VFUs. Difficulties and problems should be tackled by the concerned NGOS. 
Since the issue was between DCA and PRB, FAO suggested if they could work out a solution acceptable to both NGOs.

- DCA announced vacancies for DVM positions in Afghanistan. Vacancy Announcement is attached.

III. VFU stationary required by FAO.

The standard stationary required by FAO to be provided for VFUs were distributed to all agencies. FAO reported that some VFUs visited were using the old forms and advised all NGOs to send the new forms to all VFUs, and ask their staff to use the new ones.

DCA commented it has already printed and distributed the required forms to it's VFUs, the new forms will need additional expenses.

In another comment to the head count of animals, DCA asked what is the purpose of the head count, and said whether the exact number of animals surveyed in a village/district will be reported as such or if you intend to further manipulations of the data i.e. multiplication of counted units by a number in order to obtain the number of animals in a district at large?

FAO clarified that the head count would be a separate operation. Field staff have to visit the villages and obtain the information. The purpose of collecting this information is not only to get the statistics, and will enable the veterinarians to know their market. FAO will only compare the figures on seasonal basis and will not multiply or otherwise manipulate the data.

\section{Supply of Medicines}

FAO said efforts are made to support the private pharmacies, and suggested NGOs not to import medicines.

DCA in response said that the veterinarians should not be cautious when buying medicines from the private pharmacies, because there are chances of counterfeit special'ly at situation like Afghanistan with quality control and government regulations. Also the veterinary field staff and as well the farmers should have access to a whole sale and good quality medicines too.

In a question raised by the chairman whether FAO had a clear picture of medicines supply status in various regions specially the central provinces of Afghanistan; FAO said that some areas are problematic while the in towns close to Pakistan/Iran border medicines are readily available. 


\section{v. Evaluation of VFus staff}

The chairman proposed that an examination system should be devised.. for the technical and administrative staff of the regional offices of the NGOs, this may ensure the selection of qualified and suitable staff, as these positions are vulnerable to nepotism. Standard test should be designed according to the requirements of different positions of the regional offices. Probably AITM may be one of the NGOs that may help in this regard. This practice may help the better quality of monitoring, reporting and field work. NGOs opinions on the subject were asked.

FAO supported the idea, especially for the extensionists. otherwise, the decision will depend on individual NGOs.

VI. Any other business.

$$
\text { None }
$$

Participants:-

$\begin{array}{ll}\text { Dr. Hussaini chairman, } & \text { GAF, DCA } \\ \text { Dr. Samsor } & \text { DCA } \\ \text { Dr. A. Ghafoor } & \text { GAF } \\ \text { Dr. M. Kazem } & \text { PRB } \\ \text { Safi } & \text { ADF } \\ \text { Ajmal Sherzai } & \text { APA } \\ \text { T.J Barker } & \text { FAO } \\ \text { Sediqullah } & \text { FAO }\end{array}$

Garet Wassink,

DCA

Dr. Attaullah

GAF

Mohd Arif Salimi PRB

Dr. Anbergul

ADF

D. F. Cautain

MADERA

M. A. Rashid

RAFA

A. B. Mehraban

FAO

Naqib A. Noory

ACBAR 


\section{AGENCY COORDINATING BODY FOR AFGHAN RELIEF \\ VETERINARY, SUB-COMMITTEE MEETING \\ HELD ON \\ March 14, 1995}

By Naqib A. Noory

I. Approval of minutes of the last meeting

Under item V. Para 2 line 1, should not be should read as should be cautions (a typing error).

II. Announcements

DCA's Extension Manual for veterinarian has been completed in Pushto version. A copy of the booklet was distributed to the participants of the meeting. Extra copies of the publication can be obtained from the DCA's Extension Unit.

PRB had a trip to Gardez and reported that a clinic of NPO is working in the same district. PRB has been working in Gardez for the past few years and has a well established clinic. Since it was an issue of duplication, PRB proposed that NPO coordinate its activities as per the decision of the veterinary sub-committee.

PRB announced that the vaccines stored in khost has been expired and asked if FAO still recommend the use and application of these vaccines.

Regarding NPO's clinic in Gardez, the chairman said that the issue had already been discussed in this forum and NPO justified their presence that they are working only in remote areas and areas hard to reach villages of Gardez. The meeting asked ACBAR to invite an authorized representative of the agency and discuss the matter in depth at the next coordination meeting.

Regarding expired vaccines in khost, the chairman said that was already discussed in khost as per the recommendation of the FAO the vaccines could be used for another two months - after the date of expiry.

FAO reminded its Implementing partners to send their final narrative and final financial reports as soon as possible. This notice has already been given to all IPs earlier.

FAO inquired about the existence of Evaluation Committee and meetings .

The chairman reported that the committee exists and asked it will be nice that the veterinary incharge of the NGO accompany the person whom they want to evaluate. DCA will offer its Naser Bagh clinic for the evaluation team. 
The issue of women veterinarians was also raised - it was decided that they will also undergo the same procedure as the male veterinarians.

FAO said that they will be able to assist and relay messages of NGOs through radio communication to Mazar, Herat and other areas accessible.

III. Briefing of field staff gathering in khost and Jalalabad Dr. Naseri reported that $95 \%$ field staff have participated in the gathering both in Jalalabad and khost. Many issues have been raised and resolved. Problems encountered by the field staff were reported regarding veterinary services. Sale of medicines on cheaper price was an issue of concern.

The new field reporting forms have been elaborated and handed over to the field workers for future use. The gathering proved to be a successful and encouraging practice.

IV. Any other business.

DCA asked on the number of participants per NGO in the FAO extension course in Faisalabad.

PRB said that the selection of proper and professional extension workers is highly recommended and the certain qualities of the profession should be kept in mind.

FAO reported that the quota is based on the individual Implementing Partners budget.

The next veterinary meeting will be held on April 17, at 09:00 hrs at the ACBAR office.

Participants : -

Dr. Hussaini Chairman DCA

Dr. Samsor DCA

Dr. A. Ghafoor GAF

Dr. M. Kazem ? PRB

Safi

Ajmal Sherzai

M. Halimi

Sediqullah Khaliqyar

Eng. Esmat
ADF

APA

FAO

FAO

ADA
Dr. Tino Henecken DCA

Dr. Attaullah GAF

Mohd Arif Salimi PRB

Dr. Anbergul

Dr. M. S. Tahir

M. A. Rashid

Dr. Nasseri

Naqib A. Noory
ADF

MADERA

RAFA

FAO

ACBAR 


\title{
VETERINARY SUB-CONIMITTEE MUETING \\ IIELD ON \\ April 11, 1995
}

\author{
By Naqib A. Noory
}

\section{Approval of minutes of the last meeting}

The agenda and minutes of the last meeting were approved.

\section{Announcenients}

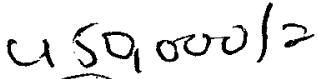

FAO announced that they will be receiving 44,000 doses of sheep pox vakeines it Macai which would be distributed to the Northern provinces.

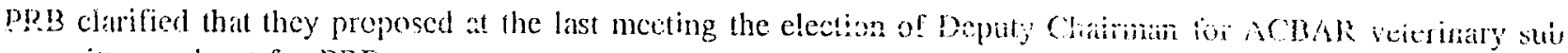
committec and not for PRB

DCA announced that a shipment of FAO vaccines will be rawhing Peshawar in the second wed at May.

F $\triangle O$ added that the results of Lahore vaccines are not yet obtained. The vaccines io be provided under rripartite

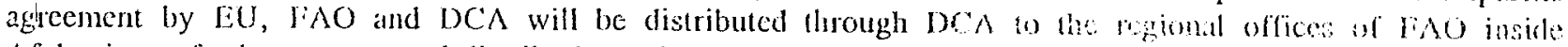
Afghanistan, further storage and distribution will be takes care by r $\$ 0$.

\section{NPO veterinary clinics in Gardez and Khost}

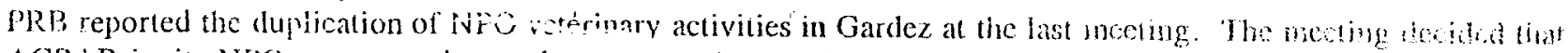
ACBAR invite NPO representative to the next meeting to discuss the reported issue of diplicat ion.

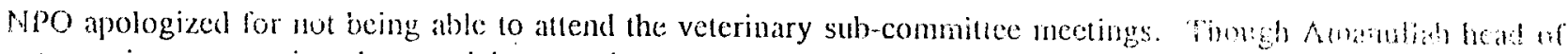
vel. bervices was assigned to participate at these mectings.

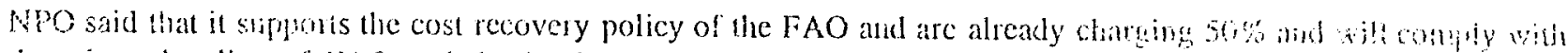

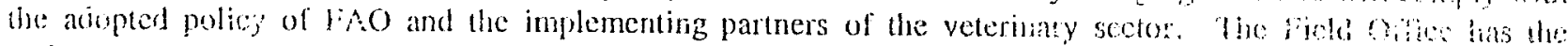
anthority to coordinate its activilies with NGOs active in the area ant make decisions ascontingly.

NPO futher updated the meeting on the locations of its clinics both in Khost wh Gaiter and said the dinica coves rencse ares, that other wise could not be looked after by the clinies existing in the thistits.

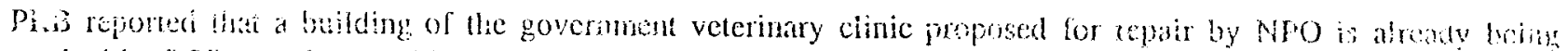

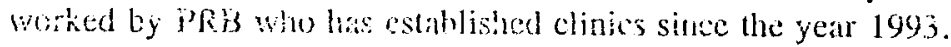

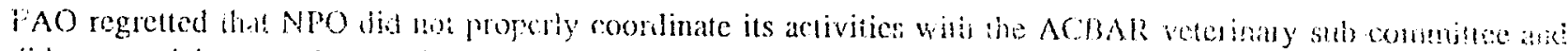
did not participate at the meseres:

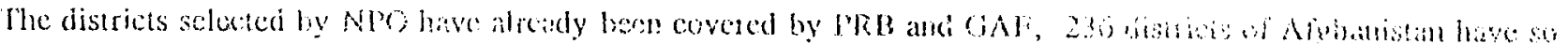

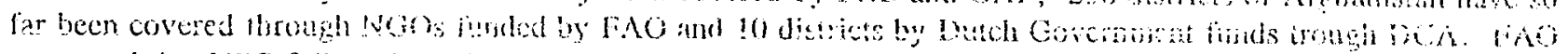

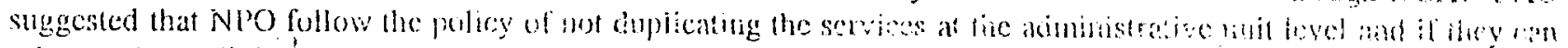

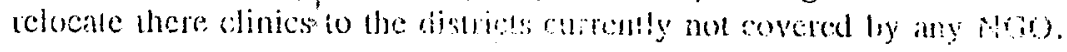

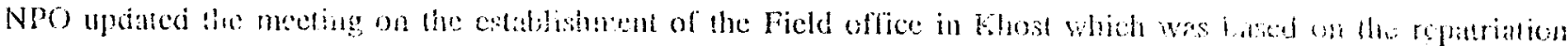

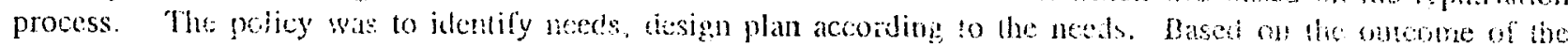

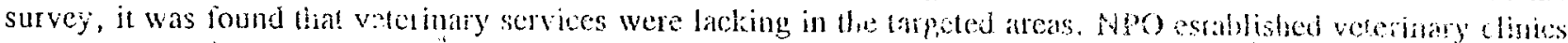
and deciden to charge so\% for the con of medicines. 
Since coordination scemed to be more eflective on site, NPO gave the authorily to the site office to make decisions and coordinate their activities with other NGOs working in the region. NPO slowed its willingness to coordinate its activities, but said that it will not be possible to abandon the clinics.

FAO added that according to the policy of the committec, technical staif of the VFUs have to be tested prior to employment, which has not yet been carricd out by NPO.

After a very lengthy discussion, the Chairman decided that GAF, PRB and NPO discuss the matter between thenseives to resolve the issue and should report to the next meeting of the sub-commuttec about the outcome of their discussion.

\section{Any other business.}

\section{- Update by UNOPS on its ponitry prograns}

Dr. Faiza updated the mecting on UNDP/OPS women programs carricd out last year in tefugec camps and inside Aghanistatl.

With the change of UNOPS and inclusion of WID program, the veterinary/poultry management programs have also becn iicluded. UNOPS has training in Nangarhar, Herat, South of Afghanistan and Northern parts of $\wedge$ fghanistan.

The manual prepared by Dr. Sherman also contain information on Pou!try Management which will soon be published. Messages of the Poultry Managencent will also be broadcasted thiough radio BBC Pushtu and Dari servioss.

PRB inciuired if the training program was of similat nature as the one designed for BVWs.

UNOPS said that the program is nearly the same. A trainer gocs to a village, sclect a group of women and gather in one house. They get trained for one week. Most of the training is practical, since the trainces are inliterate. At the end of the training, students orally explain treatment of common diseases and poultry managemat.

PRB incuired if clicks are distributed to students.

UNOPS said chicks were distributed frec of cost, but has now decided to charge for. The first position trainces receive small medicine kit to assist other in treating common/small diseases.

PRB appreciated the UNOPS house to house training program and said Afghanistan at present circumstance with weak economy does not have big chicken farms on cily levels and neither in villages. The productinns sif egg, at family farm level is very effective.

NPO reported that since 1987 they were involved in Pouitry Training Programs in the refuges camps. The program then transferted to Kunar. Training stopped and then started production programs. Nou is now planing to produce chicken iced inside Afghanistan. Results of the project were very satisfactory and heipfu! to the communities. NPO faced some difficultics with diseases that caused mortality. The manual prepared by UNOPS will be a uscful publication, NPO asked if a copy could be olsained.

UNOPS had contact the responsible of the pouitry program of NPO and said that the activity is effective. With regarist to the occursence of diseases, UNOPS said that NPO did not have techinical or trainer staff to crunter the problans.

NPO asked if UNOPS could train their starf.

UNOPS agreed and aecepted the request.

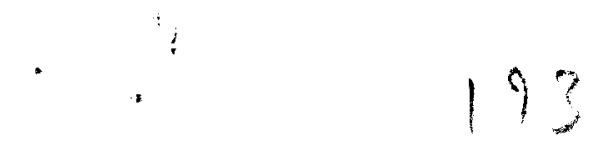


FAO added that they are in the process of developing 3 more projects. Each project will inchide 130 (raines from each unit who will be trained in incubator operations and production oi chicks. The trainces will get assistance from the VFU. This is aimed at linking poultry management/production and vetcrinary services at fietd levels.

DCA said that they have prepared sets of veterinary manuals, and containing suggestions to the villagers to keep chicks and manage poultry production. Manuals are in Pushtu, Persian and would be available for thuse interested.

The next meeting will be held on May 23, at 9 hrs at the ACBAR office.

Participants:-

Dr. Hussaini Chairman

Dr. Samsor

Eng. Esmat

Dr. Anbergul

Dr. A. Ghafoor

Mia Jan

M. A. Rashid

Dr. Barker

Naqib A. Noory
DCA

DCA

ADA

ADF

GAF

NPO

RAFA

FAO

ACBAR
Dr. Tino IJenceken

Dr. Allau!lah

Eng. Kabir

Dr. Safi

Dr.Mohd Arif Saimi

Prof. Dr.Zamarai

Nasima Andesha

Dr. Faiza Zora
DCA

GAF

PRB

$A D F$

$P R B$

PRB

FAO

UNOPS 


\title{
ACBAR \\ VETERINARY SUB-COMMITTEE MEETING
}

\section{MAY 23, 1995}

\author{
BY NAQIB. A. NOORY
}

I. Approval of agenda and minutes of the last meeting.

The number of doses of vaccines reported under announcement in the last meeting were not 44,000 , but were $4,5 ф 0,000$.

The agenda and minutes were then approved.

II. Announcements.

FAO reported outbreak of Canine Distemper in the North and said normally FAO does not have vaccine program for dogs, considering this as special case a project proposal has been prepared and is near the approval stage.

Since vaccines for Canine Distemper is not available in Pakistan, alternate vaccines were reported to be very expensive, 1 dose was reported to be Rs. 120. it needs a booster that also cost the same amount. Herd owners and local people have indicated their willingness to pay for vaccines.

FAO also reported the outbreak of Rabies in Northern

provinces of Afghanistan and mentioned that this disease resulted in the death of about 40 human beings.

Cases of Rabies were also reported by DCA and ADA in Nangarhar; Nuristan and Gardez.

DCA said that they have prepared charts and a booklet on Rabies, individuals/NGOs interested can contact the Extension Department of DCA for obtaining copies of the publications.

FAO said they are expecting the approval of a proposal under which vaccines to immunize dogs against Rabies could be procured but the dogs owners have to pay the cost. The money generated from the sale of the vaccines will be kept in a revolving fund. FAO is also trying to contact shuras, local authorities and government officials and get them involved in the process of mass immunization and eradication of stray dogs.

Regarding human beings affected by the disease, FAO reported that WHO EMRO was requested if they can provide the vaccines.

Since the issue is of public, the committee recommended that the Health Sub-Committee 
should discuss this issue with WHO, UNICEF and other NGOs working in the health sector in order to find out possible solutions.

$* * * * * * * * * * * * * * * * * * * *$

FAO and DCA had been working with the BBC Educational Drama Project and had prepared animal health and production messages which were broadcasted through the drama. The audience survey conducted by $\mathrm{BBC}$, reported that some farmers complained about the message of colostrum feeding and said that colostrum feeding have resulted in deaths of calves. FAO asked participants views of possible reasons.

DCA said based on their experience, over feeding of colostrum and E. coli infection could be the factors that might have caused the deaths. . Possible solution of the problem will be feeding of colostrum at intervals that may not cause over feeding and observing hygienic measures may reduce the mortality. The said reasons were reported to BBC, by Dr. Samsoor.

FAO asked NGOs that they should focus on the awareness and education of the field staff and be prepared for the possible outbreak of Rinderpest. FAO emphasized that the field staff should be instructed to immediately report suspected cases of Rinderpest either to their NGOs or FAO by any means.

DCA reported that a manual on Rinderpest has been published by DCA for the education of field staff and public awareness. Copies would be made available on request.

\section{Update by PRB, GAF and NPO on Veterinary Clinics in Khost}

The agencies, despite the decision of the last committee meeting did not settle the dispute themselves. The issue of duplication of the activities had been under discussion for quite a long time. Representatives of NPO and PRB expressed their views over the issue. NPO in response to a question of PRB regarding the technical qualification of their field staff said, they are of the Animal Science Department of Agriculture Faculty with long years of experience of animal health and production. The technical capability of the NPO staff became the issue of objection and intense debate. Dr. Mehraban from FAO and Dr. Saber Tahir of MADERA said that graduates of Animal Science are not veterinarians and thus have no right by any accepted standards to treat the animals or provide veterinary services.

Following lengthy discussion, the meeting decided that the concerned NGOs (PRB, GAF and NPO) should try to resolve this issue among themselves and the participants asked the Chairman of the sub committee to also participate in this meeting set for June 12th at 9:00 hrs. Result of the meeting will be reported to the next meeting. 
IV. Vaccines Status

FAO reported that European vaccines ordered by DCA for FAO from the EU fund was expected to arrive in the second week of May but this has not happened.

DCA responded to the issue and said every thing was set for the arrival of the vaccines and the DCA staff was waiting to receive the vaccine at Islamabad airport but at last minute it was told that in this flight PIA could not bring the vaccines and was promised for the next week. Vaccines for Herat has reached form Iran and will be distributed to NGOs according to the agreements.

V. Election of Chairman and Deputy Chairman

After some discussion on this issue, Dr. Hussaini was elected as the chairman of the Veterinary Sub-Committee for one more term. Dr. M. S. Tahir of MADERA was. elected as Deputy Chairperson of the committee.

Participants congratulated both the Chairman and the Deputy chairman on their election. and wished them success.

VI. Any other business

a) Clinic building construction with the help of SCA

FAO reported that contacts have been made with the Swedish Committee for Afghanistan (Jalalabad) and WFP for construction of the clinic buildings in Nangarhar province. WFP has agreed to provide Food For Work and SCA has agreed to take construction work of some clinic buildings in Nangarhar.

b) Vaccination Charges

ADF experienced some problems with the authorities in Khas Kunar over vaccination fees. The agency asked if there could be a unified policy approved by the sub committee so that the field personnel could resort to that in case there is such an incidence.

DCA said their VFU staff in Ghazni province also reported that in some districts the local authorities questioned them as why the VFUs are not giving the medicines free of cost to the farmers. The recent edition of the DCA Veterinary Newsletter contains an article explaining the adopted charging policy.

Discussion took place and suggestions were made that a Unified policy should be adopted by all NGOs.

Based on experience of the participants the following charges were recommended:

Chicks, hens

Small animals (sheep, goat, etc).

Big animals
Afs. 25

Afs. 50

Afs. 100 
c) Sending a Delegation to Kabul

It was proposed that a delegation representing the veterinary committee visit the Veterinary Department of the Ministry of Agriculture to discuss with the concerned authorities the activities of NGOs working in veterinary sector. It was recommended that a team from the ACBAR Veterinary Sub-Committee should visit Kabul for this purpose.

The idea was supported by participants, following team was nominated:-
1.
Dr. Hussaini, Chairman, Vet. Sub. Committee
- DCA
2. Dr. M.S. Tahir, D. Chairman ""
- MADERA
3. Dr. Ghafoor, Officer in-Charge,
- GAF
4. Dr. Salimee,
- PRB
5. Naqib A. Noory, Programme Manager
- ACBAR ?

The date and other arrangements of the mission will be worked out by ACBAR and will be communicated to mission members.

d) Next meeting

The next meeting was scheduled for June 13, at 9:00 hrs.

Proposed items for agenda were given:-

- $\quad$ Update on NPO, PRB, GAF and Chairman meeting.

- Kabul Visit

- Discussion on Extension Forms

- Vaccines Distribution

- $\quad$ Any Other business.

Note: All members:-

Please communicate any proposed topic for discussion for the next meeting, not later than June 5th, 1995.

Having no other business, the meeting adjourned.

\section{Participants:}

$\begin{array}{llll}\text { Dr. Hussaini Chairman } & \text { DCA } & \text { Dr. Mehraban } & \text { FAO } \\ \text { Dr. A.A. Naseri } & \text { FAO } & \text { Dr. Sediqullah } & \text { FAO } \\ \text { Dr. Faiza Zora } & \text { UNOPS } & \text { Dr. A. Ghafoor } & \text { GAF } \\ \text { Mohd Kabir } & \text { PRB } & \text { Dr. M. Kazem } & \text { PRB } \\ \text { Dr. Lutfullah } & \text { PRB } & \text { M. A. Rashid } & \text { RAFA } \\ \text { M. Harron Nessar } & \text { ARDA } & \text { Dr. Anbergul } & \text { ARDA } \\ \text { Dr. Safi } & \text { ADF } & \text { M. Haroon Jalalzai } & \text { BDA } \\ \text { Sayed Hamed Shah } & \text { NPO } & \text { Dr. Samsoor } & \text { DCA } \\ \text { Dr. M.S. Tahir } & \text { MADERA } & \text { Eng. Esmat } & \text { ADA } \\ \text { Naqib A. Noory } & \text { ACBAR } & & \end{array}$




\title{
ACBAR \\ VETERINARY SUB-COMMITTEE MEETING HELD ON JUNE, 13, 1995
}

\author{
BY Naqib A. Noory
}

I. Approval of agenda and minutes of the last meeting.

Number of vaccines reported, were 450,000. Paragraph 2. the last statement is a follow up to the next t paragraph (3).

The Minutes and Agenda of the meeting were then approved.

Since some new members participated at the meeting, a round introduction was made.

Regarding vaccines reported in the last meeting, CoAR inquired if the vaccines were for FAO Implementing Partners or for other NGOs working in the veterinary sector as well. FAO said that vaccines procured through EU funding will be for FAO IPs.

FAO said as far as the rabies vaccines are concerned, FAO does not directly support this project, WHO may supply rabies vaccine. It was mentioned that WHO may provide 150,000 doses of rabies vaccines for Afghanistan.

Considering the seriousness of rabies, recommendations were made to take the preventive measures possible.

\section{Announcements}

CoAR announced that they are supporting veterinary clinics in Waghaz of Jaghatu district of Ghazni, Baraki Barak of Logar, Shash Qala of Sayedabad, Sayedabad district center and Chak of Wardak since August, 1994. 17,236 animals have been vaccinated since the program started. The clinics are funded by NRC/NCA and EU.

PRB announced that they have conducted a pilot study around Khost on the evaluation of veterinary services provided by the NGOs for last 3 years. It focuses on how effective the veterinary program is? How much the veterinary services had contributed to the national economy because of reduction in the mortality and increase in livestock production?. Professor Zamaray of PRB asked Dr. Mehraban if he will appoint a technical committee to review the contents of the study before it is published.

The idea of appointing a committee was not supported by the Chairman as it may be considered censorship of technical publication.

Agencies were asked to contribute any available materials to facilitate the publication of this study' or if it is presented as a seminar. 
After a brief discussion, the idea of conducting seminar was supported by the committee

FAO received reports from Khost of an outbreak of a disease that caused mortality in calves. Dr. Usmani of FAO was assigned to the area and diagnosed the disease as FMD (Foot and Mouth Disease). He brought with him the samples from the lesions to be sent to a leading laboratory in England for laboratory confirmation and typing of the virus.

Regarding the possibility of diagnosis of Rinderpest, MADERA has contacted a scientist working on Rinderpest in France who showed his willingness that he can cooperate in this regard. MADERA has the technical knows how to have safe collection and has the possibility for the preservation and transportation of materials for suspected Rinderpest.

With regards to Rinderpest disease, FAO said that some has been reported from Chitral and Gilgit. Vaccination has been carried out in the area, 3 million doses of vaccines have been provided through FAO Pakistan.

\section{Update on NPO, PRB, GAF and Chairman meeting}

Following discussions in a series of vet. sub-committee meetings, it was finally agreed that NGOs involved will discuss NPO vet. activities in Khost and Gardiz, the Chairman of the sub-committee will participate as arbitrator.

The meeting scheduled for June 12 was held in the office of NPO and result was reported to the meeting.

The Chairman reported that decision has been taken to allow NPO to continue its operation till the end of 1995. NPO will consider alternate activities to undertake in the year 1996.

FAO said that since the funds are decreasing for veterinary programs and they May be forced to put some VFUs on nominal cash support this needs an assessment of economical condition of the field staff, the farmers and over all elements of sustainability. FAO asked all participants to introduce an economist who might be able to conduct a survey that might help the FAO and the IPs to create a new grade of VFUs with almost no support or nominal support.

ADA recommended that FAO and NGOs conduct the assessment of the economical status of the field staff and the VFUs with the help of the NGO and FAO monitors.

\section{Discussion on:}

\section{a) Extension Forms}

FAO reported that the forms have been distributed to all Implementing Partners and elaborated. If there is any complication or difficulty, FAO said that they will directly discuss the issue with any concerned. 


\section{b) Vaccines distribution}

FAO reported that some vaccines have been delivered by DCA to Khost. Jalalabad, and : Quetta regional offices of FAO, but unfortunately Mazar and Herat have not yet received the vaccines. Vaccines produced in Pakistan will be distributed immediately, others with longer expiry date will be kept at the cold storage of FAO regional centers to ensure they are properly stored and not exposed to extreme temperatures. These vaccines will be distributed on on season and need basis.

Dr. Mehraban of FAO mentioned of DCA that they did not take their quota of vaccines from FAO Regional Office Khost, last year. This negligence of DCA resulted to the expiry of vaccines worth around $10,000 \mathrm{US} \$$. DCA said FAO may refer to the minutes of the ACBAR veterinary sub-committee at the time of distribution of vaccines DCA has informed FAO that DCA has the supply of vaccines and only need Anthrax vaccine, FAO may distribute the quota of DCA vaccines to other NGOs.

The idea of not distributing vaccines at once to the NGOs as proposed by FAO was supported and the Chairman recommended that NGOs should be given the vaccines they can use within 3 months and the rest should be stored and at cold storage facility and should be issued on the request of the NGO as they can safely and effectively use the vaccine.

\section{Kabul Visit}

Sending a delegation from the Veterinary Sub-Committee was discussed at the last meeting. Following the decision of the committee, it was agreed that the delegation will leave for Kabul in mid June. The aim of the mission was to have dialogue and discussion with the Ministry of Agriculture regarding veterinary activities and policies of the implementing partners.

This issue was brought to the attention of the Executive Director of ACBAR and he was invited to the meeting to give his views on the proposal.

The Executive Director of ACBAR thanked members for inviting him to the meeting and said that ACBAR is in the process of establishing a sub-office in Kabul. The office will be initially housed at the Scandinavian NGOs compound. The main tasks of the office will be; to work with the NGOs and the government and establish close working relationship, to ensure that the NGOs work is well introduced. ACBAR does not support the idea of NGOs offices establishment in Kabul which raise a lot of problems, the Director said.

With regards the trip to Kabul, the Director inquired about the purpose of the mission. He agreed that there is need of dialogue with the government authorities, which ACBAR will be doing in the near future. He also supported discussion between the Vet. subcommittee and the Ministry of Agriculture, but proposed that a smaller team be assigned for the visit.. A bigger team may raise expectations of the authorities. 
The Director recommended that the committee develop a strong plan of action. At the current circumstances, there is a need to create awareness among the government, communities and the NGOs and to strengthen NGOs capacity.

The Director concluded his views with a recommendation that a small team, preferably consisting 2-3 member from the committee meet with the concerned authorities and be well prepared for the issue they aim to discuss. Agencies willing to participate in the mission are welcome, provided that they cover their own expenses. Further details would be worked out with the chairman later.

The Chairman thanked Charles MacFadden for giving valuable suggestions. The proposed visit is for the dialogue with the concerned departments of the government. The mission will be of low profile and will not unnecessary raise expectations, the chairman said.

PRB recommended that Ministry of Planning, should also be included in the visit.

FAO also said that it is necessary to build up relationship with the government. FAO plans to support the government in implementation of some projects. Results of the projects will be carefully monitored.

Charles further stressed that NGOs should stress on their valuable role in the process of rehabilitation of Afghanistan. It is well known that without NGOs the government and the donors can not work in areas where NGOs operate.

\section{Any other business}

a) CoAR Veterinary activities in Logar, Wardak and Ghazni Provinces

As announced by CoAR of their veterinary activities in the districts mentioned there is the issue of duplication. CoAR was asked to come with the detail information to the next sub committee meeting on July 11 th. The exact location of its clinic/staff in a district, list of staff with their qualification, date clinic was established, what is the policy with regard to the vaccines and medicines, who is funding the program, the activity report with special reference to the villages covered.

b) Animal nutrition and feeding programmed

FAO agriculture section asked if the committee has ever discussed other aspects of the livestock nutrition and feeding which are essential elements to the productivity of the animal husbandry programme. FAO recommended to have a demonstration plan in villages and bring general awareness among the farmers what to feed their animals with.

Discussion further extended and it was believed that the issue was of great importance. : 
MADERA reported that they have discussed the issue internally, proposal has been prepared and now waiting for some funds for the breeding and nutrition. A course is currently underway in Peshawar for the field staff in animal nutrition.,
c) Next meeting
July 11, at 9:00 hrs at the ACBAR office
d) Agenda
To be confirmed later with the Chairman. NGOs willing to bring items to the agenda should contact ACBAR not later than 6th July.

\section{Participants:-}

\section{Dr. Hussaini Chairman}

DCA

Dr. A. Majid

IRC/SRP

Dr. Ghulam Saed

CoAR

Dr. A. Ghafoor

GAF

M. Suleman

ADA

Dr. F. M. Zimery

PRB

Dr. Anber Gul

$\mathrm{ADF}$

Dr. Safi

ADF

Kotwal

FAO

Amannullah

Dr. Tahir

NPO/RRAA

A. Aq Zia

MADERA

Dr. Mehraban

FAO

FAO

Naqib A. Noory

ACBAR 


\section{ACBAR \\ VETERINARY SUB-COMMITTEE MEETING \\ Tuesday 11 July 1995}

I. Approval of agenda and minutes of the last meeting The agenda and minutes of the last meeting were approved. CoAR had received a draft copy of the minutes.

\section{Announcements}

It was reported that some FAO monitors had created an atmosphere of distrust between the NGOs and the field staff by promising things like bicycles or other equipment or the appointment of the VFU support staff while they visit VFUs. Dr. Wassink of DCA suggested that the monitors should not promise anything, unless they clearly know the budget.

The Chairman suggested that FAo monitors should work as good communicators and teachers and should try to build constructive relations between the field staff and the NGos. It was understood from the floor that this was a general problem of all NGOs concerned.

FAO stated that there might have been such a demand from the field staff or the NGOs. The monitors have been told not to promise anything - even stationeries. FAO promised to investigate the matter.

FAO stated that they have got a monitoring system designed with the consultation of the concerned NGos agencies are welcome to see the format and make any comments, if they wish.

III. Update on veterinary meeting held at EU by FAO

Dr. Wassink reported that the meeting was attended by EU, FAO, DCA, PRB, GAF, MADERA and ACBAR. The meeting discussed the problems arising in ACBAR - differences in policies.

The mentioned NGOs and donor agencies are working on a flatform and may hire an experienced person as facilitator to work out the differences and will write a common strategy proposal. The facilitator would be from ACBAR and the coordinator would be a veterinarian.

It was said that EU will most likely continue to fund veterinary programs.

Dr. Tino: requested that general policy should be looked at from different angles. This is a broad subject, he added.

The Chairman added that the ACBAR Veterinary sub-committee is the leading sector adopted a coordinated policy that has so far been very successful, therefore, it should be actively involved in the working groups of the flatworm. 
IV. Activity report by COAR on its veterinary activities

CoAR has apparently started veterinary programs for some two years. The agency was requested to come up with list of districts they are carrying out veterinary programs.

The representative of the agency stated that he has passed the message to the Director of the organization, but so far he has not received any feed-back from him. He promised to give details of the projects as soon as the Director is back from a mission.

Given the importance of coordination, COAR was strongly requested to provide the details as soon as possible.

v. Any other business

Dr. Wassink has recently returned from Kabul and had some discussions with the veterinary department. He said talking to the senior government officials they did not know anything about the implementing partners of the veterinary program of FAO, He suggested very strongly that a delegation from the NGOs should go to Kabul and visit the government authorities. The chairman said such mission has already been proposed and we are working for the logistic of it. The mission should explain the position of the Veterinary sub-committee and its policies in the field.

FAO stated that their mission to Kabul discussed the policies with the concerned authorities. However, the members still believed that the polices are not clear to the Government.

THE NEXT MEETING IS GOING TO TAKE PLACE AT 9:00 AM TUESDAY 1 AUGUST 1995. THE AGENDA WILL BE CIRCULATED LATER.

FAO suggested the NGOs to be ON TIME for the meetings.

The Participants:

- Dr. Hussaini (Chairman)

- Dr. Faiza Zara

- Dr. Tino Hennecken

- Dr. Anbergul

- Dr. Ghulam Saeed

- Dr. Samsur

- Dr. M. S. Tahir

- Shafiq Ahmad

$\begin{array}{llr}\text { DCA } & \text { - Dr. A. A. Nasseri } & \text { FAO } \\ \text { UNOPS } & \text { - Eng. M. Alam } & \text { NPO/RRAA } \\ \text { DCA } & \text { - M. Asif Rashid } & \text { RAFA } \\ \text { ADF } & \text { - Safi } & \text { ADF } \\ \text { COAR } & \text { - Gerrit Wassink } & \text { DCA } \\ \text { DCA } & \text { Dr. M. Kazem } & \text { PRB } \\ \text { MADERA } & \text { - Dr. A. Ghafoor } & \text { GAF } \\ \text { ACBAR } & - \text { Ahmad Jawid } & \text { ACBAR }\end{array}$




\section{HELD ON 1 AUGUST, 1995}

BY NAQIB A. NOORY

I. Approval of agenda and minutes of the last meeting Undar any other business, ADF will report on FMD in Kunar and Nangarhar Provinces.

Dr. Mehraban will brief the meeting on his trip to Tajikistan, Bukhara and Samarqand.

on page one last word should be platform - not flatworm.

The agenda and minutes were then approved.

II. Announcements

DCA announced that there is some savings from the exchange gain of the vaccine purchase project. This saving can be used for the purchase of additional vaccines. NGOs are requested to send the list of the vaccines they need for their programs so that DCA may supply the additionally needed vaccines according to left over budget. DCA also requested the NGOs to please send the order of the vaccines they might need for the next year so that they can plan accordingly.

III. COAR Report on vet. Activities

This issue had been discussed in the past two meetings of the sub-committee. It was decided that CoAR will. send information on the activities to this meeting.

ACBAR was asked to send a letter to CoAR and ask them to submit details of their veterinary programs in wardak and Ghazni Provinces as soon as possible.

IV. Kabul Trip

The Chairman said that due to some logistic and other matters this has not happened. DCA and FAO had meetings with the Directorate of Veterinary at the Ministry of Agriculture. DCA said that there is still need of dialogue and discussion.

FAO said that they got approval for 3 VFUs in Kabul and promised donation of equipment and support for the running cost. A proposal for Vaccine Production Laboratory in Parwan has also been recommended. An expatriate virologist who has worked at the vaccine production laboratories in Kabul may visit the lab to conduct the feasibility studies.

MADERA: said that they wanted to go to Kabul with the EU mission. A fax has been sent to France in this regard and the response has not received yet.

FAO recommended the visit of a joint delegation of NGOs for talking to concerned authorities of the rabul yovernment for the establishment of working relations, rather than the visit of individuall IIGOs. 
It was recommended that the NGOs annual reports also be given to the authorities. Copies of the ACBAR veterinary subcommittee meeting minutes will also be sent with the mission. It was suggested that minutes should be sent regularly to the Veterinary Department.

since ACBAR is not in a position to cover financial expenses of the trip, it was decided that the NGOs will cover the expenses of the trip for their respective members assigned for this mission.

Schedule of the trip will also be arranged by ACBAR and members of the delegation will be notified.

v. Any other business

out break of Foot and Mouth Disease

Dr. Anber Gul from ADF reported the out break of FMD in Kunar and Nangarhar Provinces. He recommended that vaccines be purchased and stored at the FAO cold chain system in Jalalabad.

This was further discussed and members were not supportive for providing vaccines for a number of reasons. Vaccines are expensive, immunity time is less, and needs cold chain system even at VFUs.

- FAO mission to Tajikistan, Bukhara and samarqand

Dr. Mehraban reported that he had a mission to the above mentioned places wi.th the aim of exploring possibilities of purchasing vaccines for the Northern provinces of Afghanistan. He said that some vaccines were available and were comparatively cheap.

FAO is awaiting for the response from the Laboratories visited and if agreed to the offer, Fio will be purchasing some vaccines, which will be transported to UNOCHA in Termez and then to Mazare Sharif.

The project for 150,000 doses of rabies vaccines has been approved and money received. This vaccines will probably be purchased from Tajikistan.

FAO mentioned that visas were difficult to obtain and reported communication difficulties to the outside world.

\section{PARTICIPANTS}

Dr. N. Hussaini chairman DCA

Dr. Tino Henecken DCA

Eng. Esmat : ADA

Dr. Anber Gul ADF

Dr. Tahir. MADERA

Dr. Mehraban FAO

Dr. Kazim PRB

Dr. Ghafoor ' GAF

Naqib A. Noory . ACBAR 


\section{DRAFT \\ ACBAR \\ VETERINARY SUB-COMMITTEE MEETING \\ HELD ON 5 SEPTEMBER, 1995}

\section{BY NAQIB A. NOORY}

\section{Approval of agenda and minutes of the last meeting \\ Under item I, paragraph 2, Tajikistan should be replaced with Uzbakistan.}

The agenda and minutes of the last meeting were then approved.

\section{Announcements}

DCA announced that they had a meeting with the Minis $7 y$ of Agriculture in Kabul 2
weeks back. The Ministry gave samples of American tyrtit bees hives which were
disease affected. The sample was sent to Holand and was confirmed to be affected.
Nothing could be done to control the disease, except to burn the hive/frame. The
Ministry was informed of the progress made. FAO received 4.5 tons vaccines fro the North. NGOs having veterinary programmes in
the north can get in touch with FAO and get the assigned vaccines. FAO announced that they will be starting the rabies vaccination campagin in the North. National staff from the Ministry of Agriculture have been appointed who will go to the only for dogs. The dogs which were authorities. Vaccination will start in September said that this is a test project and it implemented are suggested to be killed. FAO provices where needed.

FAO also announced that after discussion with the Ministry of Agriculture 3 sites for VFUs have been selected. The Ministry of Agriculture will set up a committee, 1 staff from the ministry, 2 veterinarians and 2 NGO stof The VFUs will be closely monitoed. vaccines specialist from Rome will visit the Lab. and see whether it will be capable to
produce vaccines or not. If it is certified so, this project will also be supported by FAO. 
DCA has published a Fertility for Cow in Persian and Pushto for extension workers. DCA added that two other publications were also announced, RABIES and RENDERPEST, but no NGO have indicated to purchase any of those.

PRB said that DCA's publications are very valueable, specially under the circumstances where there is no material for the extension workers. PRB suggested that some money be budgeted for the purchase of such publications, since NGOs can not afford to buy from their own budgets.

\section{CoAR Report on Veterinary Actvities}

This issue had been under discussion for nearly 3 months. CoAR had prepared a written report on its activites and distributed to participants present at the meeting. Regarding the employment of veterinary staff names in the VFUs, CoAR reported following members:-

Area

Khwaja Omary

Waghaze

Sayed Abad Shash Qala

Sayed Abad Center

Baraki Rajan
Name

Mohammed Naem

Mohd Gulato

Mohd Naseem

Asal Din

Faridutlah

DCA and GAF confirmed that the above people were not emplyed at their VFUs.

Since this was a duplication with GAF and DCA in both Ghazni and Wardak Provinces, it was recommended that CoAR divert its activities to Animal Husbandry or any other sector which other NGOs are not involved.

Vaccination problems and duplication were discussed. After an argumentative discussion, it was decided that GAF, DCA and CoAR will sit together and discuss the issue. A meeting will be set by ACBAR among the three NGOs and progess will be reported to the next meeting.

\section{Kabul Trip - Tentative Schedule}

ACBAR reported that due to absence of 2 members of the delegation, MADERA and GAF the mission could not leave for Kabul. The current security situation was also an obsticle to the mission as they had to travel by road to Kabul.

The meeting emphasized on the importance of the mission and supported the idea of a joint mission for detailed discussion with the Ministry of Agriculture. It was reported that the Ministry is not satisfied with NGOs performance and blame them for not implementing projects satisfactorily. Though this was debated by FAO who supports a number of NGOs for the programme. FAO said that they have sent veterinary activity to the Ministry.

Recommendations were made that NGOs should not get involved much in Kabul as they may be criticised by the Talibans or others reponsible in various provinces. 
V. Other business

\section{- Vaccines Distribution}

DCA reported that another batch of 12 million doses vaccines have been received. DCA has been informed by Brusule that a proposal for 96-97 has been prepared for about 18 million doses of vaccines.

Regarding the saving due to exchange rates, FAO said that after discussion they proposed that sheepfox vaccines of 2.3 million doses be purchased.

DCA said that the final evaluation of the project will be held during this month and the decision will be made whether to buy more vaccines or not.

FAO said that the new vaccines bottle should be collected by VFUs. New vaccines would be given upon presentation of the old bottles used.

The next meeting was scheduled for October 10, 1995.

\section{Participants:-}

Dr. Hussaini Chairman

Dr. Zimeray

DCA

Dr. Samsor

PRB

DCA

Dr. Wassink

DCA

Dr. Ghulam Saed

CoAR

Dr. A. Ghafoor

GAF

Eng. Esmat

ADA

Safi

ADF

Mehraban

FAO

Khalilullah

MADERA

Terence Barker

FAO

Naqib A. Noory

ACBAR 


\section{ACBAR \\ VETERINARY SUB-COMMITTEE}

10 OCTOBER, 1995

\section{BY NAQIB A. NOORY}

The agenda was prepared at the meeting.

\section{Approval of minutes of the last meeting.}

- $\quad$ Page 1, Item II, Para 1, line 2 should read AMERICAN FOWL BROAD.

- Page 1, para 4, 2nd line. - VFUs selected near KABUL. The Ministry of Agriculture will set up a committee, 1 civil servant from the ministry, 2 veterinarians and 2 NGO representatives will be involved in veterinary activities.

- $\quad$ Page 2, Item III, correction to CoAR staff list.

Mohammad Gulab

Farid Ahmad

- $\quad$ Page 3, Item V, Para2 - SHEEPPOX a spelling mistake.

A recommendation was made that the quantity of FAO vaccines be measured by doses instead of tons as reported at the last meeting.

The minutes were then approved with the above corrections.

\section{Announcements}

MADERA announced that one vaccination campaign of 150,000 doses of Agalactia was conducted in Kunar, Nooristan and Laghman Provinces in August - September 1995. The duration of the campaign was 20 days, 28 technical and 4 labourers were involved in the campaign. Food allowance was provided by MADERA, and there were no charges for vaccines and vaccination.

MADERA plans to conduct E.T.V campaign in October and C.C.P.P vaccination campaign in December 1995.

MADERA added that they charge for treatments, fees for various treatments were quoted. A form designed for the charges was agreed to be shared with other agencies and circulated at the next meeting.

FAO announced that Rinderpest vaccination is in the process in Paktia province. 50,000 doses of vaccines will be used. 
CoAR announced that $10,700 \mathrm{~kg}$ Premix powder and $10,600 \mathrm{~kg}$ cotton cake were sent to Wardak, Ghazni and Logar Provinces. These will be sold on a subsidized ptiçe. 17,000 doses of CCPP, 17,000 doses of NDV vaccines were also sent.

\section{BVW employment as paravets}

FAO said that they have discovered BVWs employment as paravets and even in-charge of some clinics in Paktia. Fao added that if they are technically able to work as paravets, their technical qualification should be examined.

Agencies present at the meeting said that the BVWs are employed as paravets due to lack of technical staff in those areas. They have also worked for 4 years with the NGOs. Proposals were made to change BVWs levels to vaccinators or give them intensive Paravet training to upgrade their skills.

After a brief discussion it was believed that paravets are not available to work in those areas, it was recommended that FAO fund an intensive Paravet training programme where the BVWs will be trained.

FAO representative said that he will take up the issue with the officials in Islamabad and report any progress to the next meeting.

\section{Update on Technical Evaluation Sub-Committee}

The Technical Evaluation Sub-Committee after the departure of Dr. Halimi from DCA to FAO and some other individuals fell apart.

According to reports, new appointment did not take place, except by ADF. ADF said that their new staff was evaluated by FAO, GAF based in Jalalabad.

It was strongly recommended that the Technical Evaluation Committee based in Peshawar should be approached for any veterinary professionals, not the regional offices. Following members for the committee were re-elected.
Dr. Nabi Hussaini
DCA
Dr. Tahir
MADERA
Dr. Ghulam Saed
CoAR
Dr. Ghafoor
GAF
Dr. Qazim
PRB

and one person from FAO

It was decided that all new vet. professionals should be accompanied by a representative from the introducing NGO. New Vet. Professionals should officially be introduced a week in advance.

Members of Veterinary Sub-Committee and FAO were requested to notify this policy to the regional offices inside Afghanistan. 
V. NGOs veterinary activities - evaluation once a year

CoAR recommended that the effectiveness of paravets be conduced once or twice a year. The aim of this evaluation was to improve the qualities of the veterinary services provided by various NGOs.

This was a proposal and to be conducted by a third neutral party. NGOs and donor monitoring exercises were believed to be internal.

This was further discussed, opinions varied on kinds of monitoring. Programme monitoring would be the responsibility of the donors, effectiveness would be the responsibility of implementing NGOs.

Storage of vaccines was also discussed. This was highly recommended to be followed up from Head Offices, provision of cold chain facilities were said to be lacking in many parts of Afghanistan. In order to have the best use of vaccines, recommendations were made that vaccination campaigns be arranged twice a year - which would control vaccines expiry and allow quick use of the vaccines. The individual handlers should also make their efforts to store vaccines in cold places such as wells or deep cold areas.

In order to have proper monitoring of the veterinary activities, it was recommended that FAO and the NGOs monitors should be active and capable to do the task. This was believed to be the only solution to the best control of veterinary services.

\section{Animal Head count - November}

According to the contracts signed with IPs, the Animal Head count was supposed to be completed by June. The second one is due by December. Since the first has not yet completed, NGOs proposed that the second one be conducted by November which would be completed in around 2-3 months. Vaccination campaign was also recommended to be conducted at the same time.

FAO said that according to some reports received from NGOs the head count has not been properly done.

DCA said that there seems to be lack of understanding on the form for information, training of NGOs staff was recommended in order to understand what information to collect.

\section{Any Other Business.}

\section{- Vaccines Bottle collection}

ADF said that VFUs staff have been advised to collect empty battles and return them to FAO. ADF added that this could have a negative affect since transportation is difficult for the defined places.

TAMIR said that quality control of private medicines should be conducted. 
This issue was discussed among the members of the committee and various recommendations were made.

DCA highlighted the importance of proper use of the new vaccines imported from Europe and added that some bottles were observed in Ghazni at the local market.

Having no other business, the meeting adjourned.

The Next meeting would be held on 14 November, at 9:00 at the ACBAR office.

\section{Participants:-}

Dr. Hussaini

Dr. M. Halimi

Dr. A. Ghafoor

Dr. Anber Gul

Dr. Anayatullah Samadi

Naqib Ahmad Noory
DCA

FAO

GAF

ADF

TAMIR

ACBAR
Dr. Tahir

Dr. Ghulam Saed

Dr. Kazem

Dr. Safi

Eng. Esmat
MADRA

CoAR

PRB

ADF

ADA 


\section{ACBAR \\ VETERINARY SUB-COMMITTEE MEETING}

HELD ON 21 NOVEMBER, 1995

I. APPROVAL OF AGENDA AND MINUTES OF THE LAST MEETING

Revision - Page 2, Para 1, "CoAR proposed evaluation of veterinary activities - not paravets"

Two issues raised at the last meeting were not finalized:-

- The empty bottles collection of vaccines

- Animal Head Count - proposed to be conducted in November.

These will be discussed under any other business.

The minutes of the last meeting and agenda were approved with the above additions.

\section{ANNOUNCEMENTS}

None

III. REPORT ON COAR VFUS IN GHAZNI \& WARDAK - BY COAR AND DCA Discussion were held between CoAR and DCA. The issue has finally agreed that a DCA paravet will be stationed at the Rural Development Center of CoAR at Shash Qala and Sayed Abad district center. CoAR will not send fresh vaccines/medicine supplies to the clinic. The paravets will work under the supervision of DCA and will follow the coordinated policy of FAO/DCA. The Paravet will be responsible to DCA nd is paid by DCA. CoAR said that the remaining budget may be used in Animal Husbandry.

CoAR will have funds for veterinary activities up to July 1996.

FAO said under the current budget cuts it is difficult to support 9 VFUs currently supported by DCA, funded by the Dutch Government. The Dutch Government will not fund them further. It was recommended that CoAR take over the VFUs in Wardak and Ghazni Provinces. The funds for these VFUs could be given to the VFUs of Parwan, currently being funded by DCA.

Taking over these clinics were discussed. It was recommended that this be further discussed among the NGOs involved and the donor supporting the project.

Dr. Tino recommended that a very careful decision should be taken, changing staff in these areas will slow down the activity, the old staff have built trust and are well known in the area. The issue of CoAR funds after July should also be kept in mind, if they can not support the VFUs after this period, it will be difficult to change again.

\section{PROGRESS ON THE PROPOSED PARAVET COURSE - BY FAO}

Dr. Mehraban said that since DCA is directly involved in the training sector, they might be able to share the latest information as to whether and when there will be another PVT training.

DCA said that funding is a problem. They intend to conduct three paravet courses in 1996. Funding will be discussed with IRC and a private dutch donor. Tentative plans for the courses is as follows:- 
The first course is scheduled to be held in December in Peshawar. 14 paravets will participate at this course and there will be a place for another 10 paravets. The funding decision will be taken next week.

The second course might be held in Peshawar and the third one in Herat.

It is not yet finalized whether the Charikar course will be held there or in Peshawar.

V. ANY OTHER BUSINESS

- Consultant recruitment by FAO

MADERA said that they got a letter from FAO about recruitment of an economist at their office. This issue was originally brought at the EU and ACBAR veterinary meeting. The final decision was that the consultant will be hired by a neutral body "ACBAR" in order to the socio economic study of the VFUs.

Dr. Mehraban from FAO said that this is a different consultancy from the one proposed at the EU and ACBAR meeting.

He added that the decision of that meeting was to recruit an Afghan economist to conduct the studies. It was later decided by ACBAR that an expatriate should be appointed. FAO was asked to prepare the Terms of References for the position.

There was no funding for this consultancy, EU said that they will not fund and FAO was also unable to contribute.

This consultant is for FAO. FAO got a budget cut of $25 \%$ and the aim of the consultancy is to study the effectiveness of only FAO programme not other NGOs.

DCA pointed out that similar issue was discussed at that meeting.

FAO said that the consultant will be studying veterinary activities and deciding on the issue whether to privatize Field Units are not.

MADERA thought that this consultancy could be done through the FAO existing Regional Offices.

DCA said that if FAO is going to do something to of this nature, it would be very productive to involve IPs of this sector in the discussion.

ACBAR added that a letter in this response was sent to the Programme manager of FAO by the Executive Director. So far no response has been received. A copy of the letter was sent to all NGOs implementing veterinary projects.

- Bottles Collection

After a very productive discussion, it was agreed in principal that the bottles should be collected. Further uses of the bottles will be a matter of discussion in the future.

FAO reported that their vaccines production expert will be visiting the Charikar Laboratory very shortly. FAO also proposed that MADERA get in touch with the visiting expert and provide detail on their Vac. Lab. in Kunar.

\section{- Animal Head Count}

FAO said that as reported at the meeting held last week in Islamabad, this will not continue next year. The extensionists were also said to be not funded in the new CSAs. Though a different activity will start. 
NGOs who have completed the animal head count during this year do not need to do it again. Those who have not done it during this year will need to complete it next year.

FAO reported that 50,000 dogs were vaccinated against rabies in the North. 150,000 doses of vaccines were purchased and 50,000 doses have been stored in Islamabad which could be used in the South-East provinces. Suggestion of a partner was made who will sell the vaccines, collect the money and buy more vaccines and have this system as revolving. The NGO has the freedom to sell the vaccines on whatever price they want, but are obliged to buy vaccines with the money for continuation of the programme.

FAO also said that the rinderpest is under control in Afghanistan. A consultant will be visiting Pakistan to assess the disease and will be going to Khost as well. According to reports received from Khost, 40,000 animals have been vaccinated in the area. About 35 animals have died. No other reports have been given about deaths. FAO intends to increase awareness so that the cases of outbreak could be reported immediately.

$* * * * * * * * * * * * * * * * * * * * * * *$

CoAR reported that some veterinary clinics were visited in Ghazni Province. Some BVWs and even paravets did not have detail information about the schedule of vaccination, contra indication to pregnant animals and the immunity period. CoAR recommended that this awareness be created among the VFUs.

The chairman said that a timetable for all vaccines have been prepared and distributed along with the vaccines supplied to the FAO Regional Offices to be distributed to the field staff. The chairman stressed that NGOs should make sure that these charts are available at VFUs.

FAO also said that they will make sure that the instruction are distributed to all VFUs.

The next Veterinary Sub-Committee meeting will be hold on 19 December at 9:00 hrs at the ACBAR office.

Having no other business, the meeting adjourned.

Participants:-

Dr. N. Hussaini Chairman

Dr. Tahir D. Chairman

Dr. A. Ghafoor

Dr. Ghulam Saeed

Eng. Esmat

Dr. Dad Mohammad

Safi

Dr. Tino Hennecken

Dr. M. Kazem

Dr. Luftullah

Dr. Mehraban

Naqib A. Noory

DCA

MADERA

GAF

COAR

ADA

ADF

ADF

DCA

PRB

PRB

FAO

ACBAR 


\section{ACBAR \\ VETERINARY SUB-COMMITTEE MEETING \\ 19 DECEMBER, 1995}

Revised

16 January 96

\section{APPROVAL OF AGENDA AND MINUTES OF THE LAST MEETING \\ The agenda and minutes of the last meeting were approved.}

II. ANNOUNCEMENTS

DCA announced that they did not come to an agreement to sign the new CSA with FAO and will not continue FAO funded VFUs in 1996. The reasons for not agreeing to the new CSAs are as following:-

1. The extra task assigned to the VSC in-charge does not seem to be achieved with the reduction of money.

2. There were not sufficient funds for the over head-cost to achieve activities effectively. During 1995, DCA managed to carry the activities through other funding.

3. The process of privatisation needs extension services which were not included in the new CSAs. The 1996 will face a complete drawback of extension services.

DCA said that they will continue VFUs in Herat and expand to Ghor and Badghis Provinces. Funding has been agreed by the EU and Dutch Government up to mid 1996.

DCA during 1996 would mainly focus on training and see if a training center could be established in Charikar. 4 VFUs in Parwan will also continue.

FAO added that DCA will continue to import vaccines. FAO added that all DCA programme will continue as it was, except CSAs are affected.

FAO said that they were sad about DCA's decision. The agreement could not reach due to insufficient funding.

Extension activities have been agreed. This will need a very focused effort to train the extensionists. The extensionists will directly relate to the VFUs.

This new approach has been implemented in many countries and have proved to be successful. An example of similar approach was given where farmers refused to vaccinate their animals. After the visit of the extensionist- and veterinarian to the village and joint discussion for two days, all farmers agreed to vaccinate their animals.

The various approaches of the new extension programme were elaborated by FAO. FAO added that this will be training of extensionists as trainer, who will train VFUs staff. 
PRB had gone through this similar approach and visiting the villages for more than three times. They were still not able to convince the farmers to get their animals vaccinated. PRB said that medicines charges are also important to keep in mind. Some farmers never agreed to vaccinate their animals and claimed that due to vaccination they lost some of their animals. The reason for this might be incorrect dose of vaccines.

FAO said that the implementing partner for Hazarjat region will be OXFAM. The VFUs in Wardak will be managed by ADA. The Ghazni, Logar and Nangarhar VFUs will be managed by GAF. PRB will take over the Paktika VFUs. FAO said that the personnel and equipment will remain in the clinics, the management will change.

FAO added that the Herat VFUs will continue through DCA.

The floor expressed more involvement in Training of Extensionists. In order to achieve successful privatisation, training is considered to be a vital component.

After a long discussion on the subject, it was decided that this item will be discussed at the next veterinary sub-committee meeting. Dr. Samsoor, specialist in extension training will give presentation and the background of the programme since DCA started.

\section{RINDERPEST UPDATE - BY MR. T. J. BARKER, FAO}

Mr. Barker reported that rinderpest was found after diagnosing in September in Khost Province. Within a few days FAO Rome had given authorisation to purchase 50,000 doses of rinderpest vaccine from the Pakistan Programme and commend a ring vaccination operation.

This was a valiant effort but it could not succeed without the full commitment of the farmers, the veterinary services and the authorities to vaccinate and to prevent the movement of cattle and/or infected meat, Mr. Barker added.

Rinderpest is still there in Khost. FAO confirmed it less than a week ago. It is also possible that it was actually present in Afghanistan before FAO found it in September.

Mr. Barker said that rinderpest is a disease of veterinary services. It is a failure of field vets to recognise the signs, and failure to pass on those signs and warnings to the proper authorities and to FAO, or to anyone else who is in a position to act, he added.

Your VFU veterinarians failed us. The reason that your vets failed all of us here is because they, your vets, refuse to visit the villages and the farmers, they expect the farmers to come to them, Mr. Barker said.

Since I have been with this programme I have been trying to preach this essential need. VETS MUST VISIT FARMERS NOT the other way round.

We all know that vets do not go out of their clinics. I feel sure that $80 \%$ or more of the cases they treat they do not even see the animals. This is not a veterinary service this is a pharmacy business, and it is a disgrace to the veterinary profession. 
Therefore in the New Year FAO is going to achieve three things.

* to make sure that vets visit farmers, and if they do not they will not be paid;

* to make sure that vets/paravets and even BVW either recognise rinderpest or that they report every diarrhoea case to someone who does;

* finally any outbreak of a serious disease, such as this, will have dire consequences for the vet in that area.

The way FAO proposes to do this.

* to hold consultation sessions with all veterinary personnel at which FAO will demonstrate with role playing better methods of approaching farmers. FAO also has a new extension training package which in due course will help in this regard.

* FAO will continue training in disease recognition with particular emphasis on serious diseases.

* $\quad$ FAO will insist that any report of diarrhoea in cattle or buffaloes should be followed up AT FARM LEVEL. Any vet who does not follow this procedure and rinderpest is proved in his area will be sacked on the spot without pay.

Mr. Barker added that in the new CSAs they are asking vets to go to the field for 10 days every month. Personally I will expect them to go $4-5$ days per week ( 15 days per month) at this stage, he added.

FAO will expect vets to understand and recognise the essential signs of all notifiable diseases. For rinderpest these are:-

- Diarrhoea with fever (a temperature);

- Lesions in the mouth and on the tongue (not on the feet or on the teats).

* Many vets look for a blackened anal mucosa. THIS IS VERY RARE and is not a diagnostic symptom;

* Many vets expect cattle to die. This does not necessarily happened but mortality rates can also be high;

* In any case it is safer to report a suspicion than to risk not recognising the disease.

As to the present situation, FAO is undertaking the following steps.

* Starting an awareness campaign aimed at everyone but particularly farmers.

This includes notices on the BBC Pushto service, posters are being prepared and will be distributed, announcements will be organized from mosques and by 'loud speaker;' 
* Enlisting the help of Taliban to restrict all movement of cattle and to organize vaccination campaign;

* Start a training session in Khost for all vets and parvets and BVWs where possible (this will include a video for which FAO will get Taliban clearance);

* Finally FAO will initiate a vaccination campaign of upwards of 250,000 doses.

NGOs can help FAO in many of these actions but the first action they must complete within the next week is to send to FAO in Islamabad all head counts collected from their VFUs even if our regional offices have not cleared them yet. Please indicate this if the Regional office has not cleared them. Where VFUs have not done them get them done this week.

Gentlemen we must all pull together in this matter and we must make sure that in future no outbreak gets away from us we must all be much more on top of the situation, Mr. Barker said.

Dr. Samsoor from DCA said that the disease was first reported in Pakistan. He said that DCA at that time had provided a booklet with the aim that the staff will know the symptoms of rinderpest. Copies of the publication were distributed to all veterinary implementing NGOs. NGOs were asked to write their comments on the publication, no comments were received. NGOs willing to have more copies of the publication are welcome to contact DCA.

\section{ANY OTHER BUSINESS}

The next veterinary sub-committee meeting will be held on 16 January 1996 at 9:00 hrs.

Having no other business, the meeting adjourned.

Participants

Dr. M.S. Tahir D. Chairman

Dr. Attaullah

MADERA Dr. Ghulam Saeed

COAR

Dr. Zimeray

GAF

Mr. J. M. Maizy

PRB

Dr. M. Kazem

PRB

Dr. Samsoor

PRB

Dr. Safi

DCA

Wynn Flaten

Eng. Esmat

A-Aid

Dr. Tino Hennecken

ADF

ADA

Dr. Mehraban

DCA

Dr. T. J Barker

FAO

Liz Spencer

FAO

Ross Everson

ACBAR

Naqib A. Noory

ACBAR

ACBAR 


\title{
Pamir Reconstruction Bureau
}

\section{Veterinary Project \\ PRB/95/001}

Funded by FAO

Activity Report-1995 for

\author{
North-east zone provinces of \\ Kunduz, Takhar and Badakhshan
}


Pamir Reconstruction Bureau their veterinary activities Fleld Units) in Kunduz and zone of Afghanistan.
(PRB) had been starting establishing since 1991 with 4 vet. clinic (vet. Takhar provinces of the north east

The maln alm of offering this kind of service was keeplng animals healthy and productive, prevention of the occurance of infectious diseases of animals, upgrading of livestock production, which is one of the important factors in the national export commodities and national income of the country that evolves approximately 80 s of the national forelgn exchange.

The maforlty of the national economy is based on agriculture and animal husbandry sectors and therefore taking into consideration of these factors as well as the sultable environmental situation we were able to extend our service centers to 23 vFus within the three provinces of Kunduz, Takhar and Badakhshan by 1995.

Our professional staff at present includes 10 vets (at DVM level) as Incharge of VFUs, 33 para-veterinarian, 23 guards and 79 active BVWs (Basic Veterinary Workers).

To manage and organize the activities better and to make it more effectlve at villages in-charge of VFUs, 27 BVYs at the region.

level we could provide 16 motorcycles Eor blcycles for paravets and 57 bicycles for

The mentioned 3 provinces are having mild climate most sultable for agriculture and anlmal husbandry services with total human population of $1,648,000$ (according to the geographical map-1981) speaking Dar1, Uzbak1 and Pashto languages.

Total area estimates about 107455 square $\mathrm{km}$ of which Kunduz and Takhar provinces are having enough area irrigated and well fertilized land sultable for varleties of agricultural products where as Badakhshan province covers mountalnous areas very fit for Ilvestock ralse.

The maln agricultural products are wheat, rlce, oats, corn, ollseeds and the livestock industry mainly involves sheep, goats, cattle, horses and poultry.

Estimated anlmal head count by VFUs personnel in the concern districts of the said three provinces shows the following numbers :
1. Cattle
441827 heads
2. Goats
581177 . heads
3. Sheep
1101967 heads
4. Horse
28289 heads
5. Camel
8869 heads
6. Donkey
110324 heads
7. Poultry
1008343 heads
Tota 1
$3,280,796$ heads 
Livestock Industry is still based on traditional manners that is the large number of animals producing. the least amount of products, very little has been done about livestock Improvement mostly the animals are grazed on natural, pasture having less quantity of nutrient feed stuff.

The Importance of veterinary serves for livestock industry in Afghanistan is mainly:

1. Protection of animals agalnst varlous diseases.

2. Protection of human being against zoonotlc diseases by vaccination and treatment of animals.

3. Providing orlginal proteinlous products as food stuff for human beings.

socio-economic development and upgrading the live standard of the formers soclety.

Human being need food for their existence speclally protelnous and more speciflcally from animal orlgin, as studies have shown that one matured healthy person for his dally body requirement needs about $100 \mathrm{gm}$ protein out of which $65 \mathrm{gm}$ comes from plant and $35 \mathrm{gm}$ from animal or $1 \mathrm{gin}$. (2)

Percentage of digestable protein in animal products has shown as follows: (3)

1. Meat 16-21:

2. Milk 4 \%

3. One egg $(50 \mathrm{gm}) 6 \mathrm{gm}$

Because of shortage of animal products (Protenlous source from animal origin), studies before year 1978 (Fifth developing plan Afghanistan). Provides information that in Afghanlstan one person could recelve around $14 \mathrm{gm}$ of protein from animal origin, cherefore based on that if we calculate the need for 1648000 population in the provinces of Kunduz, Takhar and Badakhshan, the following quantity of protein requirement can be speculated.

1. $10.5 \mathrm{gm}$ from cattle, sheep and goats meat.

2. $2.3 \mathrm{gm} \mathrm{from} \mathrm{milk}$

3. $\quad 1.2 \mathrm{gm}$ from poultry product

A. To provide $10.5 \mathrm{gm}$ protein per-person from meat in those provinces the following number of animals shall be slangthered each day of the year.

a. Cattle 273 heads, b. Sheep and goats 35.57 heads

B. To provide $2.3 \mathrm{gm}$ proteln from milk the dally milk production shall reach to 9533011 ters.

c. to provide 1.2 protein from poultry products 6192 poultry and 110503 eggs' shall be produced and consumed. 
To assist the population of the VFUs area to be able to maintain their economy up to the level to receive their minimum food requirement. PRB was able to provide and implement the following technical services.

A. Treatment:

$\begin{array}{llr}\text { Kind of animal } & \text { No. } & \text { sage } \\ \text { Cattle } & 54540 & 12 \\ \text { Sheep } & 323406 & 30 \\ \text { Goats } & 118030 & 20 \\ \text { Horse } & 13306 & 47 \\ \text { Camel } & 1347 & 15 \\ \text { Poultry } & 7876 & 0.8\end{array}$

B. Vaccination:

Cattle
sheep
Goat
Horse
Poultry

C. KInd of animal

$\begin{array}{rr}176401 & 40 \\ 980850 & 90 \\ 335552 & 58 \\ 425 & \\ 249642 & 25\end{array}$

\& of disease incidence'

\% of morality out of morbidity

$\begin{array}{lrr}\text { Cattle } & 0.8 & 12 \\ \text { Sheep } & 2.5 & 13 \\ \text { Goats } & 3 & 16 \\ \text { Horse } & 0.25 & 16 \\ \text { Poultry } & 0.9 & 43\end{array}$

Apart from their technical activities other activities performed are as follows:

1. Two weeks refreshex training course for veterinarian (DVM) of all VFUs in Takhar province.

2. Ten days refresher course for 23 paravets of different VFUs in 3 provinces.

3. One month training course for 29 BVWs from 3 provinces.

4. Ten days refresher course for 30 BVWs from different VFUs in fleld office in Takhar.

5. Construction of 17 clinics bullding in different districts of the 3 provinces.

6. Performance of livestock vaccination campaign in two stages during 1995.

7. Performance of livestock head count in vfus concerned districts in 3 provinces.

Evaluating the activity of 23 VFUs in concerned alstricts of 3 provinces of North-east Afghanistan shows that in general the ituation has been improved during 1995 compare to previous time when there were no VFUs, and one could speculate livestock losses approximately $30 \%$ (1), where as during 1995 it is estimated about 
3-48 livestock losses from disease incldence.

Looking into technical activity reports from those provinces based on clinical diagnosis the following disease incldence can still be seen in different parts in villages of the provinces as follows.

1. In cattle: Anthrax, Black quarters (Black leg), foot and mouth disease (FMD), pasteurellosis, Tuberculosis and vatious parasitic infestations.

2. In sheep: Anthrax, Enteroximia, Sheep-pox, foot-rot and different parasitic infestation.

3. In goats: Anthrax, Enteroximia, CCPp, Goat-Pox, and different Parasitlc infestation.

1. In poultry: New-castle disease, Pullorum, Coccidiosis, Fowl

To understand the Importance of veterinary services we shall mention a few points regarding economic evaluation of our the following number of axple immuned agalnst different animal diseases in onated and probably in Takhar province. Cattle $=4429$ iseases in one VFU of Talogan and Poultry $=19760$.

- If we conslder the cost of one cattle Afs. 1,000,000 we see that Afs. 4,429,000,000 is saved to the national income.

- If we consider the cost of one sheep Afs. 100,000 therefore Afs. $5,890,8000,000$ shall be saved to the national income.

- In the same way if we count the cost of one goat Afs. 100,000 , totally Afs. 1,378,100,000 will be saved to the nat lonal income.

If we think that one chicken costs Afs. 6000, totally Afs. $118,560,000$ w111 be saved to the national income.

Therefore the calculation shows that only in Talogan area of the activity of our one VFU totally Afs. 11,816,460,000 is saved to the national income of the country during 1995. Meanwhile the total running cost of (PRB concern) one VFU for the year 1995 is Rs. 167508 = Approximately 20100954 Afs.

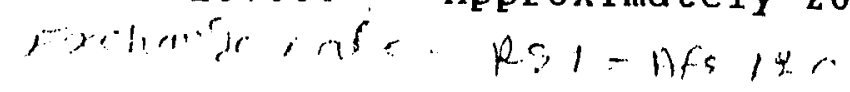

It is also to be mentioned hat this amount of national income is ith the exception of the cost of the products and by-products of
the animal treated.

For further improvement of veterinary services; preventive and prophylactic measures and Increasing the animal production level the following recommendations are needed to be submitted.

1. Non avallablilty and higher price of veterinary drugs in north east region requires that the necessary medicaments must be supplied by the project to their concerned vFus and their very urgent supply would be the following items: 
Nilzan drench, Vernil, systamix, Valbazine bolus (cattle), Valbazine bolus (sheep), oxytetracycline inj., Combipotic inj., teramycine $1 . A$ inj., Kaolin powder, sodium bicarbonate powder, Mag.sulphate powder, Neguvon powder, DCP powder.

2. To organize an effective vaccination campaign the supply of different vet. vaccines must be' on time to avold the seasonal occurance of Infectlous disease that is at least 2 months before the season the vaccines should be supplied to VEUs.

3. The vaccines provided to VFus are usually less than their need therefore VFU personnel need to supply their requirement from avaliable market resources which cost them more than the project supply. An other considerable point is the over date vaccines in free market that were kept in nontechnical condition which may not induce the necessary immunity.

4. to Improve and upgrade the technical level of the field staff necessary books and 11 terature shall be provided to each VFU.

5. Establishment of a vet. clinical laboratory in Taloqan town.

6. Continuation of curative, preventive and prophylactic veterinary services to clear the focal points of disease Incldence as well as livestock and livestock production development programs must be set up to improve the socioeconomic aspects of afghan society at the region.

To maintain animal health situation in Badakhshan province, PRB was so far able to establish only 3 VFUs in Falzabad, Baharak and Kishm districts.

Cattle, sheep, Goat, Horse, Donkey, Yolk, Poultry are the important $k$ ind of domestic animals.

Number of livestock in Badakhshan province as whole in 1967 had been estimated by the ministry of planning of the Govt. of Afghanistan as follows: (Soclo-economic survey of Badakhshan Volume-I 1907)

$\begin{array}{lr}\text { Cattle } & 173050 \\ \text { Bheep } & 387770 \\ \text { Goats } & 253210 \\ \text { Karakul sheep } & 2190 \\ \text { Buffaloes } & 1090 \\ \text { Camel } & 760 \\ \text { Horses } & 21160 \\ \text { Donkey } & 57310 \\ \text { Poultry } & 220750 \\ & --2-0 \\ & 1,117,290\end{array}$


Practlcally looking Into the matter, the geographlcal and climatic condition of different districts as well as long winter and very weak soclo-economlc status of Badakhsan's soclety shows that the important factor in their economy can be the livestock Industry. As it is noticed the reach to vet. service from one district to another is practlcally impossible. Therefore we shall strongly recommend the expansion of the number of our vFUs to 13 so that more number of farmers can be benefitted. We hope that the authorities concerned and international humanitarian donors may kindly consider the situation and assist us to extend the establishment of our vFus in every distrlct in Badakhshan province.

\section{Reference}

1. Aksoy.F.Tahlr-1.994

Tavuk

Yetistirlcillgi

Sahin Maxbaas 1

Ankara

2. Argun-Turut, 1979 PP 522-535

Infectlous and parasitlc diseases of anlmals Pulhan Matbaasl Istanbul

3. ZImery.F.M - 1986

The Importance of animal protein in human dletry (In Dar1) Natural sclence

Kabul UnIversity 


\section{COAR VETERINARY AND ANIMAL HUSBANDRY ACTIVITIES FOR AFGH ANISTAN}

CoAR is an Afghan NGO. and started its activities in different fields like agriculture, and construction, since 1989 and 1992 the sectors of veterinary, health, and education in Logar, Ghazni and Wardak Provinces. The people of the concerned areas needed assistance there for CoAR decided to organize and integrate its activities through its RDCs (Rural Development Centers) over there to control the above mention activities in the above mention Provinces. CoAR still has some problems because a few veterinary existing clinics need to be more organized and improved. and staff can not solve their problems. So the improvement of staff also should be considered. The details of on going Animal husbandry and veterinary activities are as follow:

\section{1- ANIMAL HUSBANDRY}

CoAR has been involved in animal husbandry program in Sayed Abad of Wardak Province since 1992 - 1993. The main purpose of these activities are distribution of sheep and poultry to the widows and orphans in order to make them self reliance. CoAR distributed about 3000 and 650 feyomy chickens in 1992 and 1993 respectively. They were distributed in different widows and orphans families in Sayed Abad district. In 1994 CoAR has distributed about 184 sheep both male and female to 92 families of widows free of charge. I have to say that CoAR has a sheep farm in Sayed Abad, the total number of the sheep are 165. The above mentioned farm is under the control of Zana khan sub office. In 1994 about 65 metric tones cotton seed meal and about 3156 pkts of milk care were distributed in Ghazni, Wardak, Logar, Provinces. Beside of these activitiesCoAR has honey bees in Sayed Abad district the total number of them are 132 boxes. The honey bees for me is control by a former professional and expert staff of ministry of agriculture.

\section{II - VETERINARY}

\section{a) Vaccination.}

Like other NGOs, CoAR has a vaccination programme against main infectious diseases, to reduce the mortality and morbidity of different animals. The vaccination programme has been running under the policy of F.A.O and the decision of ACBAR the veterinary staff take some fee from the animals owners the detail as follow:

Cattle-100 Afs Sheep - 50 Afs Poultry-25 Afs.

The vacines which are used in COAR VFU for the protection of the animals are as follows:

Anthrax - Enterotoxaemia - Hemorrhage Septicemia - black leg - N.D.V. CoAR had only one refrigerator to keep the vaccines in it but unfortunately it was in Kabul under repair, But we keep the N.D.V.' in the refrigerators of AMIA -AVICEN and SWEDISH COMMITTEE. I would like to mention that some of the vaccines which were necessary for the field like sheep-pox-ccpp we do not have them.

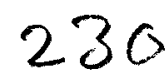




\section{b: EXAMINATION AND TREATMENT.}

For examination and treatment the animals were brought in the clinic, the medicines which are used for treatment of the animals are not free, the farmers are willing to pay the medicines cost $100 \%$ of purchase price. Only the dressing is free of charge due to the policy of ACBAR.

\section{VFU AND VETERINARY STAFF}

\begin{tabular}{|c|c|c|c|c|c|c|c|}
\hline & \multicolumn{2}{|c|}{ Location } & & \multicolumn{3}{|c|}{ Staff } & \\
\hline Province & District & Center & $\begin{array}{c}\text { No. of villages } \\
\text { in } \\
\text { service area }\end{array}$ & doc & p.v & $\begin{array}{l}\mathrm{v} \\
\mathrm{a} \\
\mathrm{cc}\end{array}$ & Total \\
\hline Wardak & Sayed Abad & Shash Qala & 32 Villages & $\ldots$ & 1 & -- & 1 \\
\hline Wardak & Sayed Abad & Sayed Abad & 47 Villages & $\cdots$ & 1 & -- & 1 \\
\hline Logar & Baraki Rajan & Qala Qazi & 15 Villages & - & 1 & -- & 1 \\
\hline Ghazni & Waghaze & Kudly Sham Shire & 25 Villages & -- & 1 & -- & 1 \\
\hline Ghazni & Khwaja Omary & Qala Haider Khan & 26 Villages & -- & 1 & -- & 1 \\
\hline
\end{tabular}

FUNDED SOURCES: NRC/NCA - EU.

The activities area of the Clinics:

R.D.C manage different activities as well as possible, the veterinary activities also include in this R.D.C but the area that is covered by clinics is for from the center. According to the interviews and information from the project area the demand of the population and vet. services have not been fulfilled.

\section{THE MAIN PROBLEMS OF COAR IN THE FIELDS}

- CoAR,s clinics cover a wide area with a large number of animals. The present veterinary staff and the limited number of clinics are not able to help the communities.

- Some medicines have been brought in big bottles and one bottle can not to be used in the proper time and the Medicine are very expensive too.

- At the present time CoAR does not have refrigerators for the vaccines.

- It was decided by the board of CoAR to employ one D.V.M as a supervisor for GCG (Ghazni

Coordination Group) office to manage the veterinary service of CoAR in Logar, Ghazni and Wardak provinces.

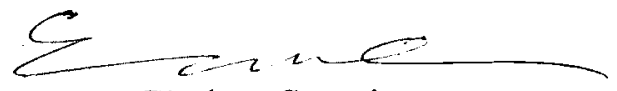

Dr. Ghulam Saeed, 

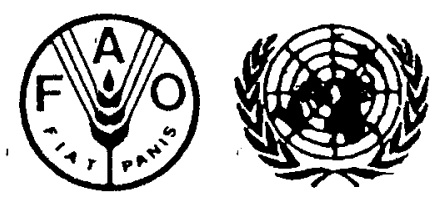

PROJECT AFG/93/004

Animal Health and Livestock Production Programme for Afghanistan

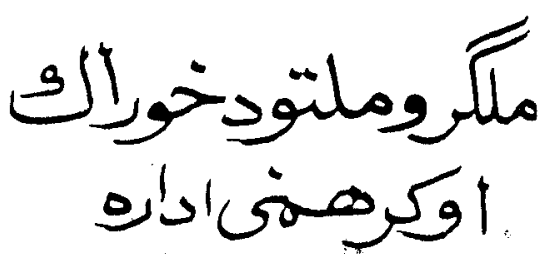

Discussion Paper No. 1

\section{Discussion on New CSAs - 1995}

\section{Introduction}

The 1995 CSAs contain four new elements which have all been discussed but perhaps not fully enough and I wanted to take this opportunity to further air the subjects. The four new elements are: the livestock headcount, the vaccination campaign, extension and the slightly new grading system. The grading system is an important subject that is wider than the scope of this paper and it will be dealt with separately. Nevertheless, all these four ideas are being developed for a single reason -- to help VFUs to move more surely and more quickly towards selfsustainability.

The purpose of these ideas therefore is to train and to assist those vets and paravets to grasp the fact that soon they will be on their own and support will be minimal (for those that have not yet understood this), that is all salaries will be withdrawn. The vets must achieve a number of things to guarantee their independence: they must know the size of their market, they must sell themselves to that market (the farmers), they must develop a good working and financial relationship with the BVWs in their areas, they must develop an assured and reliable source of supply for medicines and so they must create a strong bond between all members of the farming community.

\section{The Livestock Headcount}

This was originally called a livestock census. The name was changed for two reasons: the word census tends to suggest an official undertaking, in terms of the government of the country which we are not, and it also indicated to some people that this would be a detailed undertaking. At this stage we do not want it to be, indeed it must not be, a detailed study. One point is very clear -- officialdom (either government or project or NGO) cannot take a vet away from earning money through giving services to farmers unless he is paid. We cannot therefore ask the vets to undertake a detailed survey unless we put up much more money than we are doing so at the moment.

Nevertheless, it is necessary to have a good idea of the numbers of animals in the project districts and we have in the past tried to obtain these numbers through the disease report form. This has not been successful because more often than not 
the single headcount line was never filled in, neither was it checked or corrected by the IP Monitors. When it was filled in it was not always consistent. Therefore we developed the notion of helping the vets to meet the farmers. At the same time they would help both themselves and us by carrying out a simple straight livestock headcount. This must not be complicated otherwise it will take too much time and it would then take the vets away from their more important work.

Two counts a year are allowed for in the budget: June and December. This will help to ensure accuracy, it will provide an update for the figures and it will force the vets and paravets to visit the villages and the BVWs. In this way they will confront their market and develop relationships with the farmers and BVWs.

\section{Vaccination Campaign}

This is another device not only to improve health care but also to put vets face to face with farmers and to develop a working relationship with the BVWs of their district. The idea is that by paying daily subsistence for a short while to the VFU then the vets, paravets and the BVWs will work together and they will share the income generated. This sharing of income has to be developed if the vets and BVWs are going to live together in a sustainable relationship in the future. For instance in years to come the control of the use of antibiotics should be in the hands of the Veterinarian, but he will be unable to attempt any controls in the present climate (without a government, veterinary association or other policing body) unless he has a financial relationship as well as a training one with the BVWs.

Therefore during the vaccination campaign all the VFU personnel should look out for and refer cases of illness or injury amongst the animals to the senior vet, who should then share the fees collected with the BVWs as well as the other VFU staff. This should also be looked upon as a general conditioning for the sharing of fees whenever the vet visits a BVW in the future. In the normal course of events and on a weekly basis, the vets and paravets should be visiting BVWs to help them and to offer them continuous training. The vets will be reluctant to do this because it takes them away from their own earning time. It is therefore essential that they build up a mutual financial relationship. I feel that the vaccination campaign is a training tool with which to do this.

As a spin off, the vaccination campaign should achieve greater coverage than at present, it should guard against miss-use of vaccines, such as selling in the market place or just throwing away, and it should help to make the VFU more sustainable in terms of practice partnership and market orientation.

\section{Extension}

The approach of the NPPP Monitors and the IP Monitors has to become less of a policing function and more of a teaching/'selling' function. In addition the approach of the VFU vets must be much more of a selling/service offering function. It is felt that an extension mentality would be very effective in helping 
all sections of the veterinary community to address farmers in a more sympathetic fashion and to form a bond with them as partners, rather than viewing them as: either ignorant or as a community to be browbeaten.

In this regard it is felt that the extension input would also benefit from PRA training (Participatory Rural Appraisal), if it were possible to provide.

T.J. Barker

Programme Manager

AFG/93/004
Discussion Paper No. 1

4 January 1995 


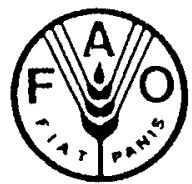

PROJECT AFG/93/004

Animal Health and Livestock Production Programme for Afghanistan

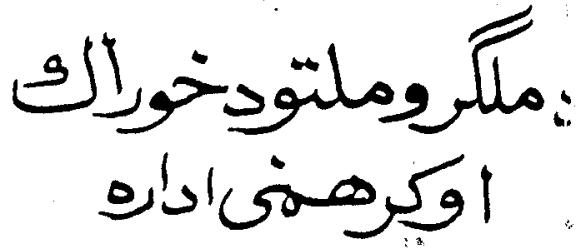

Discussion Paper No. 2

\section{The Future of the NGOs in the VFU System}

\section{Introduction}

Many of the ideas used in the 1994 VFU grading system (Establishment, Support and Maintenance) are incorporated into the new Grades I, II and III. The latter system, developed for the 1995 CSAs, is a more complex but we hope a more rational system suited to the developing situation. This developing situation has implications for our Implementing Partners (IPs), the NGOs. But the concept and the policy remain the same, i.e. to help VFUs to move more surely and more quickly towards self-sustainability. Looking to the future, we have to consider the situation under a peaceful National Government where funding will change and the role of the IPs will be very different.

In the development of animal health care services in Afghanistan we are still a long way from covering the whole country. At the present time we are now only covering 236 of the 325 districts and we have to find ways and means to finance full coverage, or as much as possible out of a limited budget.

\section{Targets}

By the end of 1996 the Project document envisages at least 170 VFUs on maintenance grade. However, the goal posts have now been moved a little in that we have now created three new categories in place of the old ones: Grades I, II and III. Currently Grade III is more or less equivalent to the old maintenance category. In the 1995.CSAs we only have 56 Grade III VFUs instead of the targeted 120 in the Prodoc. Therefore there appears to be a gap between what we wish to achieve and what we are achieving. This is somewhat counter balanced by the fact that Grades $I$ and $I I$ are considerably lower, in terms of salary levels, than their former equivalents (establishment and support). For example, the salary of a Grade II veterinarian has been dropped from Rs. 5,000 per month to Rs. 3,500 in 1995.

Nevertheless, clearly we are going to have to move faster.

Therefore in the 1996 CSAs we would like to see at least some VFUs on a nil salaries grade, let us call it Grade IV. This means that their support will only be given to them for the headcount, vaccination campaign, monitoring and extension activities. It also means that a whole lot of new VFUs could be brought in at the Grade I level. 


\section{The Implications}

The last case mentioned above must be the preferred option from the IPs point of view because the admin finance allocation can only go up if new VFUs are opened and this can only be done if old VFUs move to Grade IV.

In development work such as this we are supposed to work ourselves out of a job, and the way that this project has been set up it appears to be no different both for the project and for the NGOs. The greater the sustainability of the VFUs the less the money needed from outside to support them and so the lower the value available for administration and the running of such organisations as the NGOs.

Nevertheless there is still much work to be done and there are capable people around like the veterinary-committed NGOs to do it. By 'the work to be done' I mean that we are covering $73 \%$ only of the districts so far -- we still have the best part of 100 districts not yet covered by VFUs.

This reinforces the need to have some VFUs on the nil salary grade by the end of 1995. It also means that if you want your'support level to increase then the more VFUs you have on Grade IV the more you may be able to support new VFUs on Grade I, the highest salary grade, which in turn means a higher level of admin income.

\section{What Has to be Done}

Starting from now each IP, separately and together with our Regional Offices, will have to review each VFU very carefully in terms of staff ability and sustainability, it will have to monitor those VFUs very thoroughly and it will have to start a campaign to prepare the minds of the veterinary staff in those.VFUs for the reduction in their salaries. The extension budget line in your budgets is there partly in order to give some support to this need. Our Regional staff will be doing the same thing independently and they will be discussing their conclusions with each IP.

Every IP must have at. least one VFU which will be able to support and sustain itself even perhaps at this time, but no VFU Vet is going to admit that and so it will be up to you to persuade the more successful VFUs as to what is in store for them in the future. Clearly the more an IP is able to show itself to be capable of moving VFUs to Grade IV the more likely they are to be given responsibilities for the new Grade I VFUs.

\section{The Alternatives}

The solution to the IPs' dilemma outlined above is necessarily short term because we do not at present know if there is going to be a further phase to this project. There are other solutions: to go out of business at the end of 1996 , or to develop into fully sustainable operations yourselves. 
To become fully sustainable yourselves suggests that you may wish to develop into some kind of a "Super Practice". By this I mean that you will take over the management of the delivery of veterinary services to the districts for example by amalgamating several districts, employing the VFU staff on a cost-sharing basis. Another method of recovery would be to become suppliers of medicines and vaccines to the VFUs through "Super Wholesaling" -- getting your cut by competing in the market place with the advantages of scale. There are probably many other systems but they will have to be worked out and tried in the field.

\section{Conclusion}

The future is uncertain and change is inevitable, a fairly normal human condition. If we are all to ride those major changes that will be upon us in two years time then we have to prepare now. More importantly we have to prepare and condition the vets, paravets and BVWs, as well as ourselves, to ride out these changes in the cause of efficient and sustainable animal health care delivery.

T.J. Barker

Programme Manager

Discussion Paper No. 2

AFG/93/004

4 January 1995 


\section{Livestock mortality in Afghanistan in districts}

\section{with and without a veterinary programme}

preliminary report on an impact study

Bram E.C.Schreuder * DVM; Nicolaas Noorman**; Mohibullah Halimi * , DVM, MVsc; and Gerrit Wassink* * DVM .

- DLO-Central Veterinary Institute, P.O. Box 65, Lelystad, The Netherlands

- DCA-Veterinary Training and Support Centre, Monitoring Dept., Univ. P.O. Box 792, Peshawar, Pakistan

DESCRIPTORS: Epidemiology-; Afghanistan-; Cattle-diseases; Mortality-rates: Sheep-diseases; Goat-diseases; Mortality-; Ruminants-; Disease-surveys: Surveys-: Cattle-; Sheep-; Goats-; Livestock-; 


\section{SUMMARY}

This paper reports on livestock mortality in a country where a war has been going on for more than a decade, with, as one of the consequences, complete disruption of the veterinary field services. The study was an effort to measure, in a limited number of districts of Afghanistan, the impact of a veterinary field programme carried out mainly by paravets. The study also provides valuable data on the impact of diseases in the absence of any veterinary intervention.

The veterinary programme, implemented by a Dutch NGO in these districts for approximately 3 years, consists essentially of a preventive vaccination programme against major infectious diseases. Another important part of the programme is the provision and administration of anthelmintic drugs, both against nematodes and liver flukes. Veterinary personnel is, in addition to preventive actions, also involved in curative treatments.

Livestock mortality figures covering a period of two years were collected on livestock belonging to farmers in four districts with (covered) and four districts without (control) a veterinary programme. This was done by means of a questionnaire survey, administered by neutral enumerators. More than 700 farmers were interviewed in the analyzed districts and in at random selected villages, half of them in covered areas, the other half in control areas.

Annual mortality was defined as the number of animals dying during an observation period of one year as proportion of the animals present at the start of the same observation period. For young animals, mortality was defined as the number of young animals dying as proportion of the animals born in the same observation period.

Summarizing for the two year period, this figure was for young animals:

$16.2 \%, 17.3 \%$, and $19.1 \%$ in the covered areas, against $21.5 \%, 25.2 \%$, and $24.6 \%$ in the control areas, for calves, lambs, and kids, respectively.

Adult mortality figures were considerably lower: $3.8 \%, 7.4 \%$, and $5.4 \%$ in the covered areas, against $5.3 \%, 13.6 \%$, and $15.6 \%$ in the control areas, for cattle, sheep, and goats, respectively.

The survey indicated a significant difference $(p<0.05$ in cattle, $p<0.001$ in small ruminants) in livestock mortality between the control and covered areas: the mortality in young animals was reduced by roughly 25,30 , and 22 percent, in calves, lambs, and kids. respectively. Adult mortality was reduced by roughly 30,40 , and 60 percent, in cattle, sheep, and goats, respectively. It is assumed that the preventive actions were responsible for most of the effect of the animal health programme. 


\section{INTRODUCTION, BACKGROUND, AND SCOPE OF THE STUDY}

The livestock sector is of major economic importance to Afghanistan, providing important constituents of the daily diet and a source of income for more than $80 \%$ of the population. The Soviet invasion in December 1979 triggered off a decade of war in which complete villages, cities, and most of Afghanistan's infrastructure, including irrigation canals, were destroyed. Human death toll exceeded one million, and more than 5 million people, equalling one-third of the population, fled the country. Rural Afghanistan witnessed in this period a complete disruption of veterinary services, a situation still continuing over large areas. This has led to serious threats to the already decimated livestock population. The agriculture survey carried out by the Swedish Committee for Afghanistan (SCA) in 1988 indicated that numbers of livestock inside Afghanistan were approximately half of pre-war figures (SCA 1988).

With the establishment in September 1988 of the Veterinary Training and Support Centre (VTSC) in Peshawar, Pakistan, by the Dutch Committee for Afghanistan (DCA), an emergency orientated veterinary programme was commenced, aimed at providing basic veterinary care for the remaining Afghan livestock population. The DLO-Central Veterinary Institute (CDI-DLO) has provided technical backstopping from the inception of the project. A number of other organizations, most of them NGOs (non-governmental organizations), also got involved in veterinary activities, and DCA/VTSC has trained paravets for a number of them. The German-Afghanistan Foundation (GAF), also operating from Peshawar, Pakistan, was the first organization involved in this field. Other NGOs, among them Experiment in International Living (EIL), had their base in Quetta, Pakistan, and concentrated their inputs in South-Western Afghanistan. In 1990, after the withdrawal of the Soviet army, also the Food and Agriculture Organization of the United Nations (FAO) moved in, with as basis government-controlled Mazar-i-Sharif, aiming at providing veterinary services to livestock holders in Northern Afghanistan.

The training of intermediate level veterinary auxiliary staff ("paravets") was undertaken. Students were recruited, in close consultation with local commanders or with other local authorities ("shura"), from areas where need for veterinary assistance was identified. Upon graduation, students were deployed in these areas inside Afghanistan, within the structure of "Veterinary Field Units" (VFUs) under the supervision of higher qualified veterinary personnel. Their tasks are primarily in preventive veterinary medicine: vaccination campaigns against major infectious diseases in large and small ruminants and in poultry. Vaccinations are done at regular basis against anthrax, blackleg, enterotoxaemia, haemorrhagic septicaemia (HS), and Newcastle disease in target animals. HS vaccinations are done in certain regions in the South-East only. Another important part of the programme is the provision and administration of anthelmintic drugs, both against nematodes and liver flukes. In the absence of any reliable recent data on disease incidence in Afghanistan, the field programme had been based on disease reports from FAOimplemented projects in the early seventies and even earlier (FAO technical reports, 1955 and 1973). These reports stress the importance of parasitic diseases in this country, which is in line with the first author's own 2 years field experience in the North-Eastern provinces of Afghanistan. Veterinary personnel is, in addition to these preventive actions, also involved in curative treatments.

The personnel in the Veterinary Field Units is posted in such a way that they can be expected to cover mo'st of a district, each of them being assigned to a different duty station within that district. The field programme witnessed a modest start in spring 1989 , with the establishment of the first VFUs. By the end of 1992, the DCA/VTSC field programme covered, to a varying degree, 33 districts in 13 different provinces (out of 29), 
for logistic reasons concentrated in the East-Central, North-Eastern and Eastern regions (see map).

Gradually the DCA-VTSC programme has changed from an emergency orientated programme to a rehabilitation programme for veterinary infrastructure and services. In certain districts, field activities had been going on for three years, allowing an evaluation of the impact of the programme.

This paper reports on a survey on livestock mortality. The survey is limited to districts where activities were initially started, using as "control" areas, adjacent or nearby districts that had been devoid of organised veterinary care for more than 10 years. The collection of data on livestock-production and health under war-like conditions make the survey unique in its kind, but the same prevailing conditions entailed numerous practical and methodological difficulties.

\section{OUTLINE OF THE STUDY}

"How to assess the impact of a veterinary programme?"

In general terms the aims of the concerned animal health programme are:

1) to prevent losses of livestock, and

2) to increase productivity of existing livestock.

Under "normal" conditions, measurement of the impact of such a scheme should include checking disease incidence (disease surveillance) and the impact on production and mortality. This was not feasible under the given circumstances as cold-chain facilities were lacking and laboratory confirmation of disease outbreaks could be considered virtually nonexistent. What remained possible were farmers questionnaires. The survey focused on the collection of data on livestock productivity and mortality over a period of two years. In this report, only the data on livestock mortality will be presented.

\section{METHODS}

\section{III.1 Study population and selection of survey areas}

Selection of control districts and matching of districts:

Initially, 7 districts that had, according to the available information, 3 years functional animal health coverage, were selected in 6 different provinces. These were called the "covered districts". An equal number of "control" districts was selected, areas where no veterinary care had been available for, say, 10 years. Most of the latter districts were adjacent to the covered districts. Care was taken to ensure that the control areas were comparable with the areas covered by the animal health programme, in respect to ecological conditions and animal husbandry. This would allow for a comparison between pairs of districts.

\section{Selection of villages and farmers:}

Three villages were randomly selected within each selected district, both covered and control. To this end, a list of villages for each of these districts was drawn up and villages were given a numerical code (according to the Provisional Gazetteer, Ministry of Interior. Kabul, 1975). A random selection was made from these using a random number generator. 
In each selected village, 30 farmers were to be interviewed. Selecting 10 large, average, and small farmers per village, this sample should be representative for the whole village: This brought the total of interviewed farmers to 90 in each district.

\section{III.2. The questionnaire}

The questionnaire, prepared in "EPI-INFO" (Center for Disease Control, Atlanta/WHO, Geneval, was used in the summertime, which is after the lambing season and also after the main calving season. Most of the questions covered a period of two years, the two years immediately preceding the survey. The questionnaire covered a number of items, but for this preliminary report only the questions dealing with mortality are considered.

A distinction was made between mortality among young and adult animals, mainly because different rates in these different groups have a direct impact on the productivity of a livestock population. Differentiating between these two groups may also assist in pointing out lacunae in the animal health scheme.

In addition, questions were included on the presence or absence of animal health measures, the availability of medicines and anthelmintics, and on the numbers of livestock owned, in particular for large and small ruminants.

\section{III.3. The enumerators}

The enumerators administering the questionnaires of this survey were trained staff of the Agriculture Survey Department of the Swedish Committee for Afghanistan (SCA) (thus from an organization differing from the implementing agency), most of them having approximately five years experience in this field. The enumerators received additional instruction prior to their missions and were debriefed upon completion of the survey.

The field work was carried out in the summer and early autumn of 1992 . On average, it took each enumerator two months to complete his district, including travel time.

\section{III.4. Analysis of results}

Analysis of the data was done using Lotus spreadsheet programme vs.3. For statistical analysis Statcalc was used, the statistical module of EPI-INFO (CDC/WHO). For calculating statistical differences between the individual pairs of districts and the combined figures, a contingency table was used (Chi-square) with Yates correction.

Annual mortality (in adult animals) was defined as the number of animals dying during an observation period of one year as proportion of the animals present at the start of the same observation period.

Animals sold, given away or consumed -- not the ones slaughtered due to disease -- were counted only half, as they were not at risk for the full period. For small ruminants, where this number was only available for the period of the last 12 months, a similar offtake was assumed for the previous year.

For young animals, mortality was defined as the number of young animals dying as proportion of the number of animals born in the same observation period. For small ruminants this was a period of approximately five to six months, ie the period between lambing season and time of implementing the survey. The latter coincided roughly with the period of weaning. For calves, weaning usually is done very gradually, at an age of one year, which also delineates the observation period. 
Initially, we intended to consider young animals "young" until mated, which is in general in Afghanistan, two years for cattle and eight to nine months for sheep and goats. For the latter, this created no analytical problems, however, most farmers prefered to talk in case of young cattle about "calves", meaning suckling calves, which reduced this group of young animals to calves till about one year age. What happened to the group of one to two years old is not completely clear, but presumably this confusion took place irrespective of project's involvement and therefore not affecting the results of this study.

\section{RESULTS}

\section{IV.1. Districts surveyed and districts qualifying for analysis}

The survey was finally implemented in 10 districts, in four different provinces. The more Northern provinces could not be reached at the time of the survey, due to severe fighting in the areas on the way.

The major criterion applied when selecting the covered districts, had been the presence of two to three years coverage by DCA-VTSC. For the control districts the major criterion had been the absence of any animal health programme. Two districts did not comply with these criteria, and did therefore not qualify for being included in the analysis of the survey results.

In the end, four pairs of districts, in four different provinces remained for analysis (see map).

\section{IV.2. Mortality in cattle in 4 pairs of districts}

Data were collected with regard to mortality in cattle, both in calves and in adults for the four pairs of districts. In the three villages selected in each district, a minimum number of 100 adult heads of cattle should be present on an average for both years of the survey. Statistical analysis was done initially within each of the pairs and $p$-values for each pair calculated. Only in two of the four pairs a (highly) significant difference in favour of the covered district was noted for adult cattle, and in three pairs for calves.

The overall figures, combined for the four districts and for both years of the survey, show a highly significant lower mortality for calves $(p<0.01)$ and a significant lower mortality for adults $(p<0.05)$ in the covered districts, as compared to the control districts. (Table $1)$.

\section{IV.3. Mortality in sheep in 4 pairs of districts}

Data with regard to mortality in sheep, both in lambs and in adults, for the four pairs of districts were collected and analyzed. In one district, numbers of sheep were considered too small $(<200)$ to allow proper comparison with its counterpart. When compairing the remaining three pairs of districts, a (highly) significant difference in favour of the covered district was noted, for bọth adults and lambs alike.

The summary table (Table 2), however, contains data from all four pairs of districts. The figures combined for both years and for the four pairs of districts show a significant lower mortality for both lambs and adults in the covered districts, as compared to the control districts. In both cases the difference was highly significant $(p<0.001)$. 


\section{IV.4. Mortality in goats in $\mathbf{4}$ pairs of districts}

Data on mortality in goats both in kids and in adults, were collected for the four pairs of districts. Again, in each district a minimum number of 200 adult goats should be present on an average for both years of the survey. When compairing the four pairs of districts, a highly significant difference in favour of the covered district was noted for adults in four pairs, for kids in three pairs.

The figures, combined for the four pairs of districts and for both years of the survey (Table 3), show a significant lower mortality for both kids and adults in the covered districts, as compared to the control districts. In both cases the difference was highly significant $(p<0.001)$.

IV.5. Summary of differences in livestock mortality between the control and covered districts (see also Figure 1)

Summarizing for the two year period, mortality in young animals was:

$16.2 \%, 17.3 \%$, and $19.1 \%$ in the covered areas;

$21.5 \%, 25.2 \%$, and $24.6 \%$ in the control areas;

for calves, lambs, and kids, respectively.

Adult annual mortality figures were considerably lower:

$3.8 \%, 7.4 \%$, and $5.4 \%$ in the covered areas;

$5.3 \%, 13.6 \%$, and $15.6 \%$ in the control areas;

for cattle, sheep, and goats, respectively.

The survey indicated a significant difference $(p<0.05$ in cattle, $p<0.001$ in small ruminants) in livestock mortality between the control and covered areas: the mortality in young animals was reduced by roughly 25,30 , and 22 percent, in calves, lambs, and kids, respectively. Adult mortality was reduced by roughly 30,40 , and 60 percent, in cattle, sheep, and goats, respectively.

\section{DISCUSSION}

This paper reports on livestock mortality figures in a country where for more than a decade a complete war has been going on, with as one of the consequences a complete disruption of the veterinary field services. The reported study was an effort to measure the impact of a field programme, carried out by mainly paravets in a number of districts of Afghanistan.

The impact of the programme seems to be the greatest for adult small ruminants, which constitute by far the moșt numerous and important type of livestock in Afghanistan. The impact seems lower, however, for adult cattle and, to a lesser extent, for young animals of all three investigated species. The confirmed presence of Rinderpest in Nangarhar province in 1991/92 (a clinical, preliminary diagnosis was confirmed serologically by the CDI-DLO, The Netherlands) could have confounded the picture for cattle, as the project was not equipped for adequate interventions (lack of coldchain facilities). 
In general, the mortality figures found in the present survey for young animals are comparable with results from studies in other countries, such as Mali (Traore \& Wilson 1988 ), where mortality in young animals was $10 \%, 28 \%$, and $35 \%$ in calves, lambs, and kids, respectively, and India (Bali et al. 1980), where the overall mortality in calves up to one year of age was $18.4 \%$.

Adult mortality figures are also comparable with studies in other countries, like the one in Mali (Traore \& Wilson 1988), where adult mortality was about $5 \%$ per year in cattle and $12-13 \%$ per year in sheep and goats. The figures in the covered areas even tend to be lower than in the Mali survey reported, and at times seem to approach figures in countries with. a well-developed veterinary infrastructure. For comparison, we present data from New Zealand (Davis 1974), where an adult annual mortality of $4.9 \%$ was found in sheep. while in the UK the annual ewe-losses are estimated at 10\% (Hindson \& Winter 1990).

\section{Possible bias introduced by the farmers or enumerators:}

It is difficult to assess the amount of possible bias introduced by the farmers' answers to the questions. Farmers probably all over the world show a tendency to adjust their statements in such a way that they think might be beneficial to them. Afghan farmers will certainly not be an exception. It may therefore be conceivable that farmers in areas without veterinary services may exaggerate their problems, in the hope that this way these services may become available earlier. It has been a specific topic during the briefing of the enumerators to pay attention to this possibility. The questionnaire also contained several cross-check questions, allowing for internal checking.

The enumerators employed for this survey were experienced and trained in this field of work. In addition, they had been recruited from a neutral organization outside DCA-VTSC, the project-implementing organization, to avoid a possible bias introduced by using field staff involved in the veterinary programme. The enumerators had no direct interest in the outcome of the survey.

\section{Discussion on the effect of the programme:}

A highly significant difference in mortality between the covered and control areas was demonstrated: the mortality in young animals was reduced by roughly 25,30 , and 22 percent, in calves, lambs, and kids, respectively. Adult mortality was reduced by roughly 30,40 , and 60 percent, in cattle, sheep, and goats, respectively.

The veterinary programme implemented in the covered areas for approximately 3 years, consists mainly of a preventive vaccination programme against major infectious diseases, as Anthrax, Blackleg. Enterotoxaemia and other Clostridial diseases. In rare instances vaccination against Foot and Mouth disease (FMD) was carried out. Another important part of the veterinary programme is the provision of anthelmintic drugs, both against nematodes and liver fluke. In addition, the field personnel is involved in curative treatments. No effort was made, however, to differentiate between the effects of the various components of the programme.

Because infectious and parasitic diseases have always caused considerable losses to livestock in Afghanistan, also in periods before the war (FAO reports 1955, 1973), it is assumed that the preventive veterinary actions have been responsible for most of the effect of the animal health programme. This is indirectly supported by the greater impact on mortality in adult animals as compared to the effect in young stock. Future inputs of 
Initially, young animals were intended to be considered "young" until mated, which is in general in Afghanistan, two years for cattle and eight to nine months for sheep and goats. For the latter, this created no analytical problems, however, most farmers prefered to talk in case of young cattle about "calves", meaning suckling calves, which reduced this group of young animals to calves till about one year age. What happened to the group of one to two years old is not completely clear, but presumably this confusion took place irrespective of project's involvement and therefore not affecting the results of this study.

\section{RESULTS}

\section{IV.1. Districts surveyed and districts qualifying for analysis}

The survey was finally implemented in 10 districts, in four different provinces. The more Northern provinces could not be reached at the time of the survey, due to severe fighting in the areas on the way.

The major criterion applied when selecting the covered districts was prior coverage for two to three years by DCA-VTSC. For the control districts the major criterion was the absence of any animal health programme. Two districts did not comply with these criteria, and were therefore not included in the analysis of the survey results.

In the end, four pairs of districts, in four different provinces remained for analysis (see map).

\section{IV.2. Mortality in cattle}

Data were collected with regard to mortality in cattle, both in calves and adults for the four pairs of districts. In the three villages selected in each district, a minimum number of 100 adult cattle should be present on average, for both years of the survey. Statistical analysis was done initially within each of the pairs and $p$-values calculated for each pair. Only in two of the four pairs a (highly) significant difference in favour of the covered district was noted for adult cattle, and in three pairs for calves.

The overall figures, combined for the four districts and for both years of the survey, show a highly significantly lower mortality in calves $(p<0.01)$ and a significant lower mortality in adults $(p<0.05)$ in the covered districts, compared to the control districts. (Table 1$)$.

\section{IV.3. Mortality in sheep}

Data were collected and analyzed with regard to mortality in sheep, both in lambs and adults, for the four pairs of districts. In one district, numbers of sheep were considered too small $(<200)$ to allow proper comparison with its counterpart. When compairing the remaining three pairs of districts, a highly significant difference in favour of the covered district was noted, for both adult sheep and lambs alike.

The summary table (Table 2), however, contains data from all four pairs of districts. The figures combined for both years and for the four pairs of districts show a significantly lower mortality in both lambs and adults in the covered districts, compared to the control districts. In both cases the difference was highly significant $(p<0.001)$.

\section{IV.4. Mortality in goats}


Data on mortality in goats both in kids and in adults, were collected for the four pairs of districts. Again, in each district a minimum number of 200 adult goats should be present, on average for both years of the survey. When compairing the four pairs of districts, a highly significant difference in favour of the covered district was noted in adult goats in four pairs, in kids in three pairs.

The overall figures, combined for the four pairs of districts and for both years of the survey (Table 3), show a significantly lower mortality in both kids and adult goats in the covered districts, compared to the control districts. In both cases the difference was highly significant $(p<0.001)$.

IV.5. Summary of differences in livestock mortality between the control and covered districts (see also Figure 1)

Summarizing for the two year period, mortality in young animals was:

$16.2 \%, 17.3 \%$, and $19.1 \%$ in the covered areas;

$21.5 \%, 25.2 \%$, and $24.6 \%$ in the control areas;

in calves, lambs, and kids, respectively.

Adult annual mortality figures were considerably lower:

$3.8 \%, 7.4 \%$, and $5.4 \%$ in the covered areas;

$5.3 \%, 13.6 \%$, and $15.6 \%$ in the control areas;

in cattle, sheep, and goats, respectively.

The survey indicated a significant difference $1 p<0.05$ in cattle, $p<0.001$ in small ruminants) in livestock mortality between the control and covered areas: the mortality in young animals was reduced by roughly 25,30 , and 22 percent, in calves, lambs, and kids, respectively. Adult mortality was reduced by roughly 30,40 , and 60 percent, in cattle, sheep, and goats, respectively.

\section{DISCUSSION}

This paper reports on livestock mortality figures in a country where a devastating war has been going on for more than a decade, with as one of the consequences a complete disruption of the veterinary field services. The reported study was an effort to measure the impact of a field programme, carried out nuainly by paravets in a number of districts of Afghanistan.

The impact of the programme seems to be the greatest for adult small ruminants, which constitute by far the most numerous and important type of livestock in Afghanistan. The impact seems lower, however, for adult cattle and, to a lesser extent, for young animals of all three investigated species. The confirmed presence of Rinderpest in Nangarhar province in 1991/92 (a preliminary clinical diagnosis was confirmed serologically by the CDI-DLO, The Netherland\$) could have confounded the picture for cattle, as the project was not equipped for adequate interventions (lack of coldchain facilities).

In general, the mortality figures found in the present survey for young animals are comparable with results from studies in other countries, such as Mali (Traore \& Wilson 1988 ), where mortality in young animals was $10 \%, 28 \%$, and $35 \%$ in calves, lambs, and 
kids, respectively, and India (Bali et al. 1980), where the overall mortality in calves up to one year of age was $18.4 \%$.

Adult mortality figures are also comparable with studies in other countries, such as in Mali (Traore \& Wilson 1988), where adult mortality was about $5 \%$ per year in cattle and $12-13 \%$ per year in sheep and goats. The figures in the covered areas even tend to be lower than in the Mali survey, and at times seem to approach figures in countries with a well-developed veterinary infrastructure, for example, in New Zealand (Davis 1974), where an adult annual mortality of $4.9 \%$ was found in sheep. while in the UK the annual ewelosses are estimated at $10 \%$ (Hindson \& Winter 1990 ).

\section{Possible bias introduced by the farmers or enumerators:}

It is difficult to assess the amount of possible bias introduced by the farmers' answers to the questions. Farmers, probably all over the world, may show a tendency to adjust their statements in such a way that they think might be beneficial to them. Afghan farmers will certainly not be an exception. It may, therefore, be conceivable that farmers in areas without veterinary services may exaggerate their problems, in the hope that in this way these services may become available earlier. It was a specific topic during the briefing of the enumerators to pay attention to this possibility. The questionnaire also contained several cross-check questions, allowing for internal checking.

The enumerators employed in this survey were experienced and trained in this field of work. In addition, they had been recruited from a neutral organization outside DCA-VTSC, the project-implementing organization, to avoid a possible bias introduced by using field staff involved in the veterinary programme. The enumerators had no direct interest in the outcome of the survey.

\section{Discussion on the effect of the programme:}

A highly significant difference in mortality between the covered and control areas was demonstrated: the mortality in young animals was reduced by roughly 25,30 , and 22 percent, in calves, lambs, and kids, respectively. Adult mortality was reduced by roughly 30,40 , and 60 percent, in cattle, sheep. and goats, respectively.

The veterinary programme implemented in the covered areas for approximately 3 years, consisted mainly of a preventive vaccination programme against major infectious diseases such as Anthrax, Blackleg, Enterotoxaemia, and other Clostridial diseases. In rare instances vaccination against Foot and Mouth disease (FMD) was carried out. Another important part of the veterinary programme is the provision of anthelmintic drugs, both for nematodes and liver fluke. In addition, the field personnel was involved in curative treatments. No effort was made, however, to differentiate between the effects of the various components of the programme.

Because infectious and parasitic diseases have always caused considerable losses to livestock in Afghanistan, also in periods before the war (FAO reports 1955, 1973), it is assumed that the preventive veterinary interventions have been responsible for most of the effect of the animal health programme. This is indirectly supported by the greater impact on mortality in adult animals as compared to the effect in young stock. Future inputs of the veterinary programme should therefore concentrate on problems in young animals, without forsaking the present apparently beneficial constituents of the programme. 


\section{Acknowledgements}

The assistance of Mart de Jong and Herman Barkema in the design of the study is greatfully acknowledged. During the implementation of the survey, valuable support was received from Abdul Hakim Murad and Dr. Azam Gul, both from the Agriculture Survey Department of the Swedish Committee for Afghanistan. This organization also provided the enumerators, without whom a survey of this scope would have been virtually impossible. Finally, we want to acknowledge the veterinary field personnel of the Dutch Committee for Afghanistan (DCA), whose activities laid the base for the results described in this study.

\section{References:}

Bali MK; Khanna RNS; and Singh RP. (1980). Calf mortality in Hariana cattle and their cross-breds. Indian Veterinary Medical Journal, 4 (3): 115-118

Davis, GB. (1974). A sheep mortality survey in Hawke's Bay. New-Zealand Veterinary Journal, 22 (4): $39-42$.

FAO Report to the Government of Afghanistan. (1955). The control of sheep diseases and parasites. FAO Report No. 336, by MacPherson, D.A., FAO Rome.

FAO technical report, UNDP/SF project 210 (AFG/511) (1973). Final report of epizootiologist, Blaga, M.D., Kabul.

Hindson JC \& Winter AC. (1990). Outline of clinical diagnosis in sheep. Butterworth \& Co: (Publishers) Ltd. London, UK, p 62.

Swedish Committee for Afghanistan. (1988). The agriculture survey of Afghanistan. First Report, May, $68 \mathrm{pp}$.

Traore A \& Wilson RT. (1988). Livestock production in central Mali: environmental and pathological factors affecting morbidity and mortality of ruminants in the agropastoral system. Preventive Veterinary Medicine, 6 (1): 63-75. 
Table 1: Cattle mortality in four pairs of districts in Afghanistan, calculated over a period of two years

\begin{tabular}{llcccc}
\hline $\begin{array}{l}\text { type of } \\
\text { animals }\end{array}$ & district & $\begin{array}{l}\text { No. animals } \\
\text { at risk }\end{array}$ & $\begin{array}{l}\text { No. animals } \\
\text { died }\end{array}$ & mortality & reduction \\
\hline adults & $\begin{array}{l}\text { covered } \\
\text { control }\end{array}$ & 2217 & 84 & $3,79 \%^{*}$ & $28,50 \%$ \\
& 3227 & 171 & $5,30 \%^{*}$ & \\
calves & $\begin{array}{l}\text { covered } \\
\text { control }\end{array}$ & 974 & 158 & $16,22 \%^{*}$ & $24,65 \%$ \\
& 1217 & 262 & $21,53 \%^{*}$ & \\
\hline
\end{tabular}

* significant difference, $X^{2}=6.38, p<0.05$

* highly significant difference, $X^{2}=9.49, p<0.01$

Table 2: Sheep mortality in four pairs of districts in Afghanistan, calculated over a period of two years

\begin{tabular}{llcccc}
\hline $\begin{array}{l}\text { type of } \\
\text { animals }\end{array}$ & district & $\begin{array}{l}\text { No. animals } \\
\text { at risk }\end{array}$ & $\begin{array}{l}\text { No. animals } \\
\text { died }\end{array}$ & mortality & reduction \\
\hline adults & $\begin{array}{l}\text { covered } \\
\text { control }\end{array}$ & 9047 & 745 & $8,23 \% * * * 39,36 \%$ \\
& 14433 & 1960 & $13,58 \%^{* * *}$ & \\
\multirow{4}{*}{ lambs } & covered & 4830 & 837 & $17,33 \% * * * 31,22 \%$ \\
& control & 8621 & 2172 & $25,19 \% * * *$ & \\
\hline
\end{tabular}

*** highly significant difference, $X^{2}$ (adults) $=156 ; p<0.001$

$X^{2}$ (lambs) $=109 ; p<0.001$

Table 3: Goat mortality in four pairs of districts in Afghanistan. calculated over a period of two years

\begin{tabular}{|c|c|c|c|c|c|}
\hline $\begin{array}{l}\text { type of } \\
\text { animals }\end{array}$ & district & $\begin{array}{l}\text { No. animals } \\
\text { at risk }\end{array}$ & $\begin{array}{l}\text { No. animals } \\
\text { died }\end{array}$ & mortality & reduction \\
\hline adults & $\begin{array}{l}\text { covered } \\
\text { control }\end{array}$ & $\begin{array}{r}5814 \\
13701\end{array}$ & $\begin{array}{r}349 \\
2140\end{array}$ & $\begin{array}{r}6.00 \% * * * \\
15: 62 \% * * *\end{array}$ & $61,57 \%$ \\
\hline kids & $\begin{array}{l}\text { covered } \\
\text { control }\end{array}$ & $\begin{array}{l}3343 \\
6524\end{array}$ & $\begin{array}{r}639 \\
1602\end{array}$ & $\begin{array}{l}19.11 \% * * * \\
24.56 \% \%^{* *}\end{array}$ & $22.16 \%$ \\
\hline
\end{tabular}

*** highly significant difference, $X^{2}$ (adults) $=338 ; p<0.001$

$X^{2}$ (kids) $=37,0 ; p<0.001$ 


\section{References:}

Bali MK; Khanna RNS; and Singh RP. (1980). Calf mortality in Hariana cattle and their cross-breds. Indian Veterinary Medical Journal, 4 (3): 115-118

Davis, GB. (1974). A sheep mortality survey in Hawke's Bay. New-Zealand Veterinary Journal, 22 (4): 39-42.

FAO Report to the Government of Afghanistan. (1955). The control of sheep diseases and parasites. FAO Report No. 336, by MacPherson, D.A., FAO Rome.

FAO technical report, UNDP/SF project 210 (AFG/511) (1973). Final report of epizootiologist, Blaga, M.D., Kabul.

Hindson JC \& Winter AC. (1990). Outline of clinical diagnosis in sheep. Butterworth \& Co. (Publishers) Ltd. London, UK, p 62.

Swedish Committee for Afghanistan. (1988). The agriculture survey of Afghanistan. First Report, May, $68 \mathrm{pp}$.

Traore A \& Wilson RT. (1988). Livestock production in central Mali: environmental and pathological factors affecting morbidity and mortality of ruminants in the agropastoral system. Preventive Veterinary Medicine, 6 (1): 63-75. 


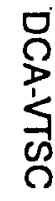

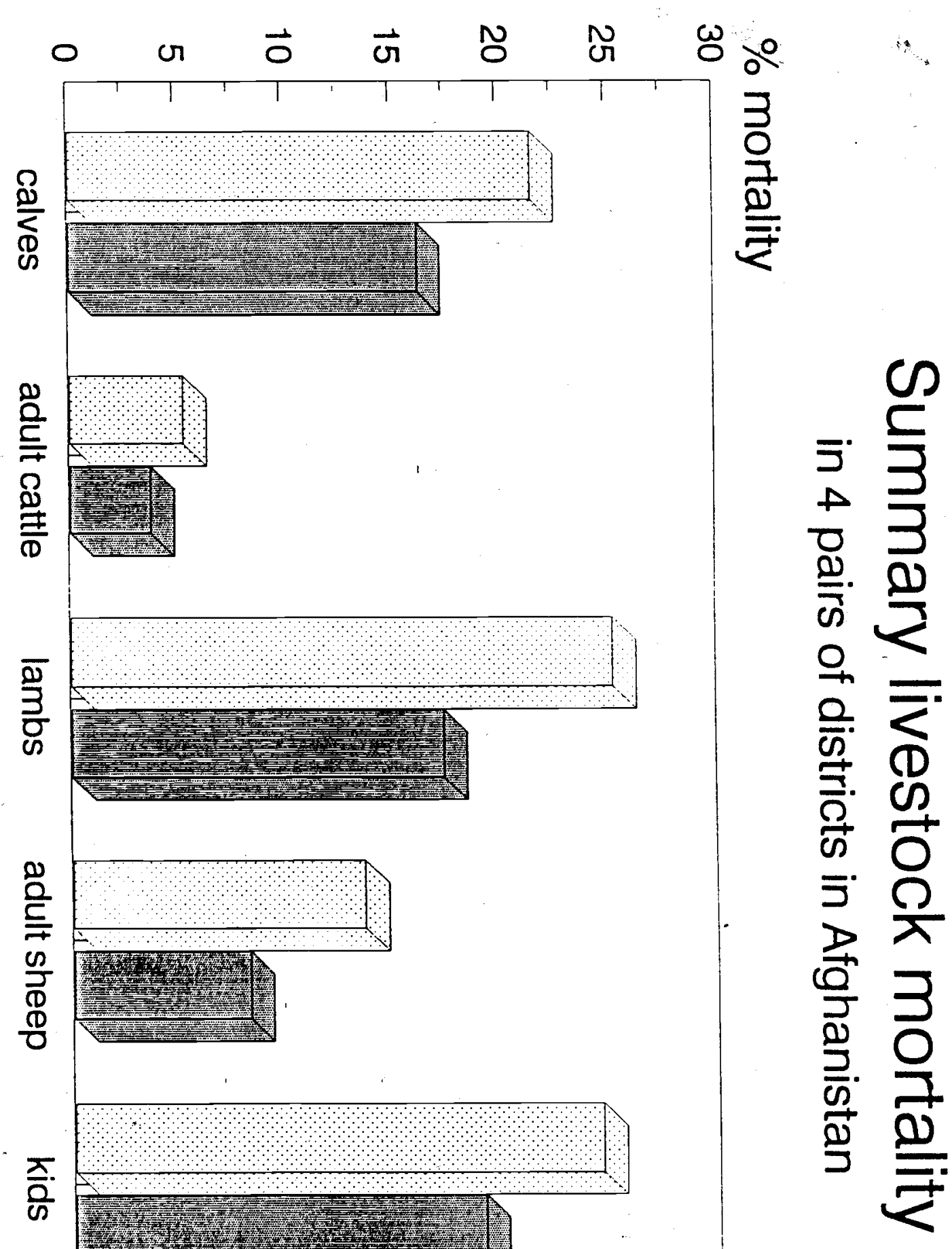




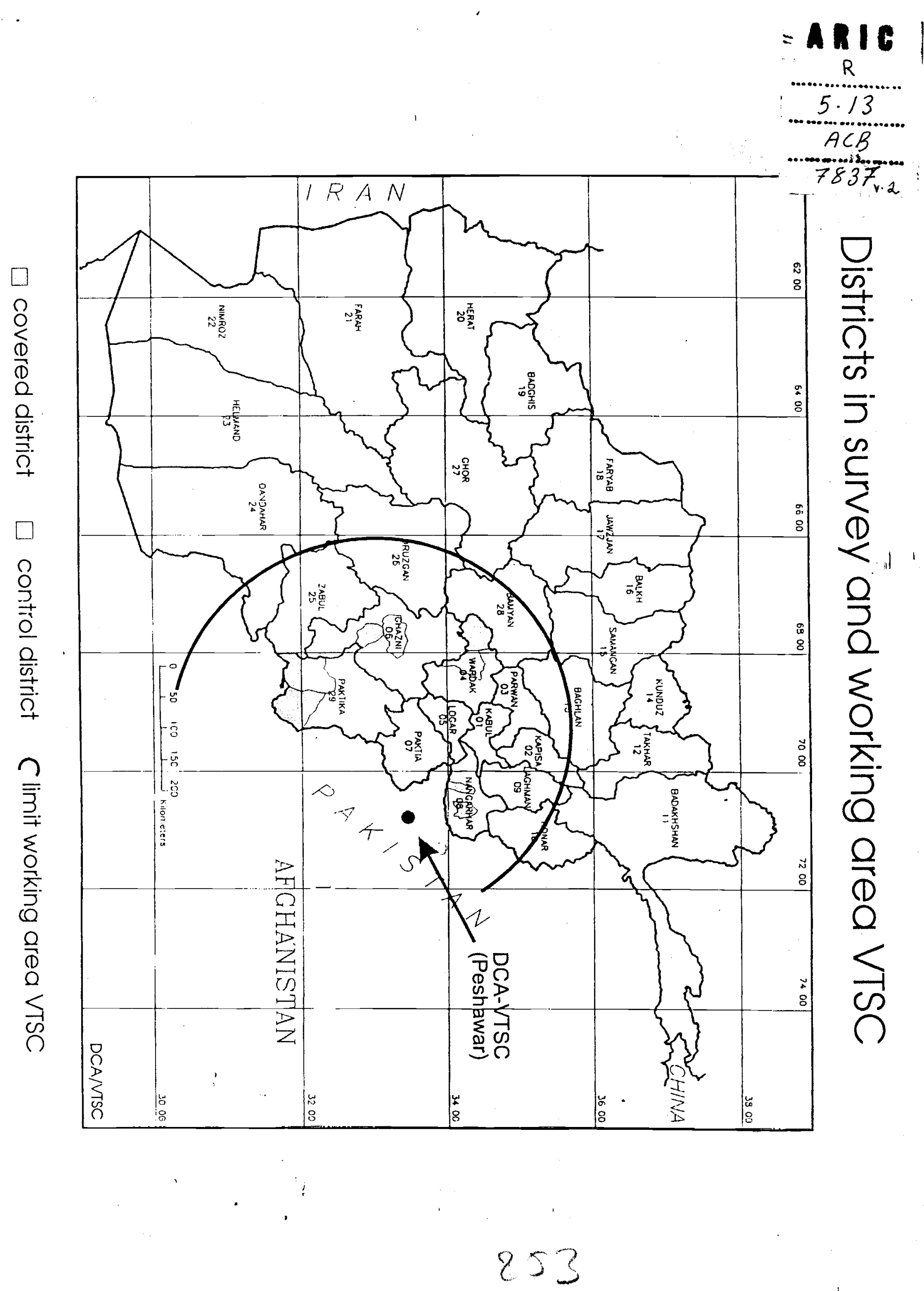

